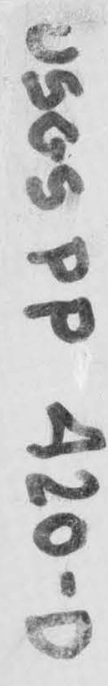

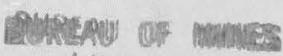

LIBRARY

GPOKANE, WASH.

JUN2 21982

MEASÉ RETURA

womar

\title{
Geology of the Northern Santa Ana Mountains, California
}

GEOLOGICAL S URVEY PROFESSIONAL PAPER420-D

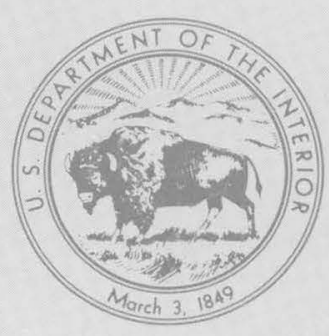




\section{Geology of the Northern Santa Ana Mountains, California}

$B y$ J. E. SCHOELLHAMER, J. G. VEDDER, R. F. YERKES, and D. M. KINNEY

GEOLOGY OF THE EASTERN LOS ANGELES BASIN, SOUTHERN CALIFORNIA

G E O L O G I C A L S U R V E Y P R O F E S S I O N A L $\quad$ P A P E R 42 P

A study in stratigraphy, structure, and structural evolution of the northern Santa Ana Mountains

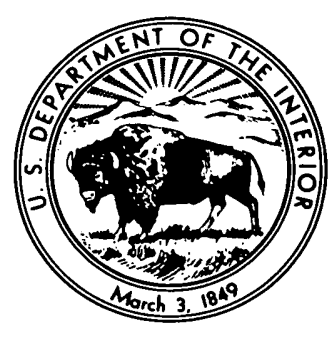

UNITED STATES GOVERNMENT PRINTING OFFICE, WASHINGTON:1981 


\section{UNITED STATES DEPARTMENT OF THE INTERIOR}

JAMES G. WATT, Secretary

\section{GEOLOGICAL SURVEY}

Dallas L. Peck, Director

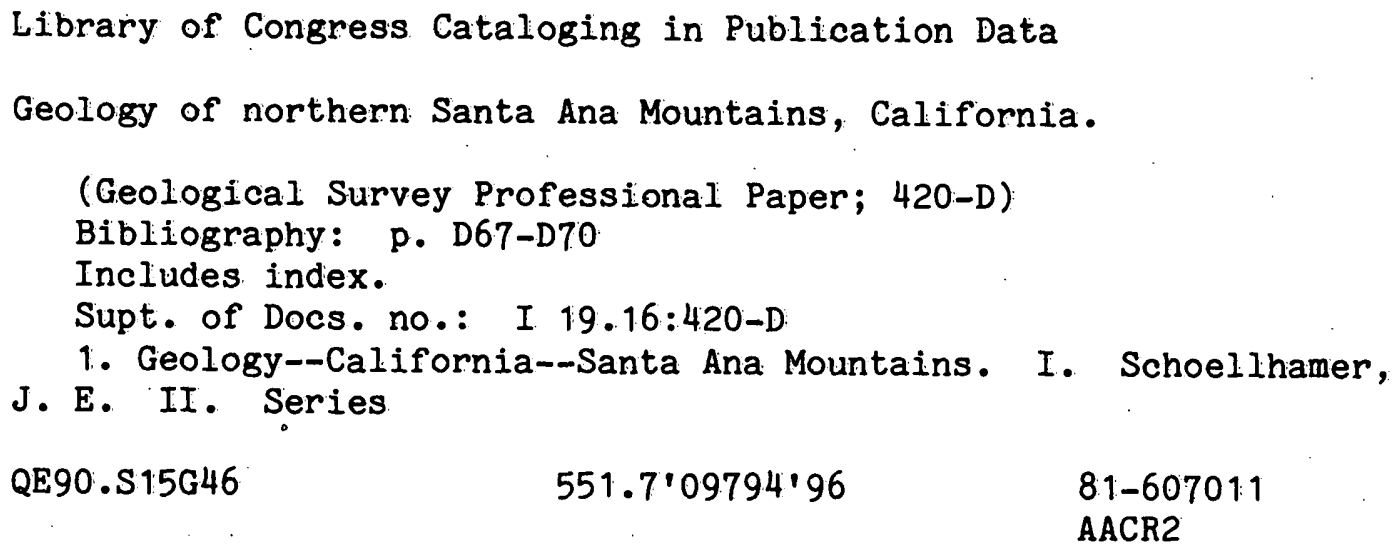




\section{CONTENTS}

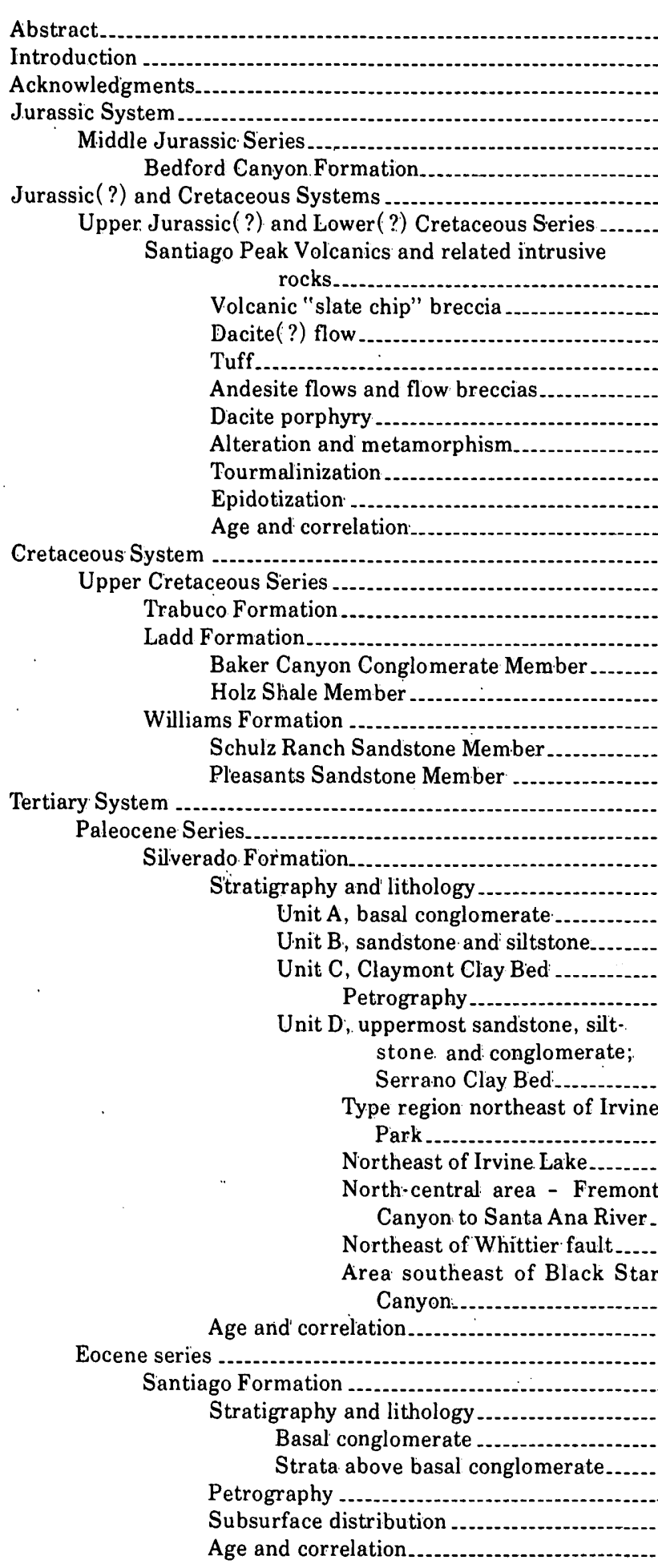

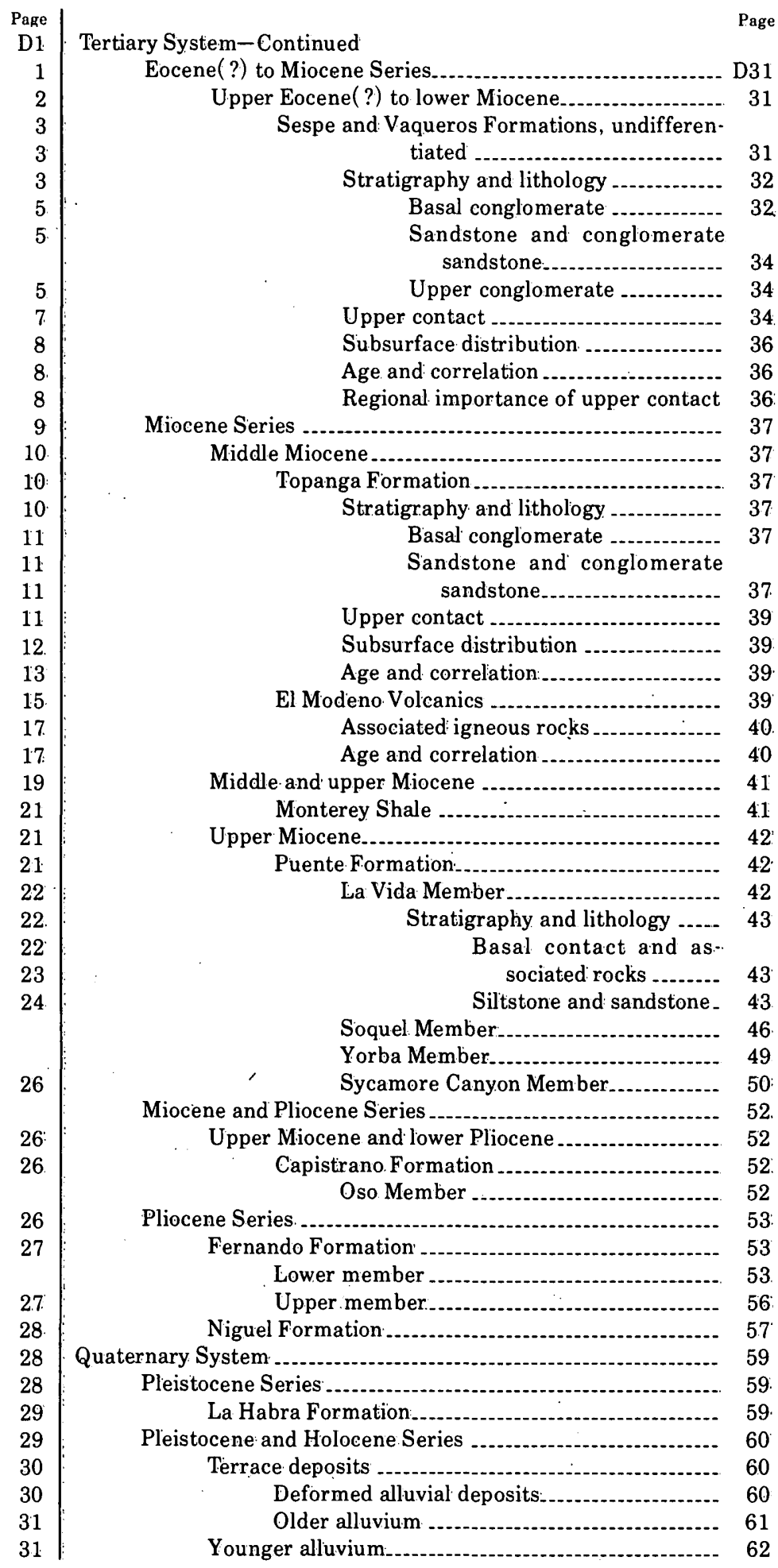


Structure

Regional structure pattern

Northeast of Whittier-Elsinore fault

Southwest of Whittier-Elsinore fault

Exposed structures .

Subsurface structures south of El Modeno fault ....

Subsurface structures north of El Modeno fault ....

Summary and regional interpretations

References cited.

Supplemental information

List of megafossils

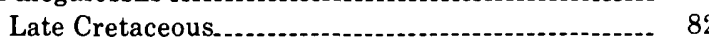

Ladd Formation ...... 82

Baker Canyon Conglomerate Member 82

Holz Shale Member ..................... 83

Williams Formation $\ldots . . . . . . . . . . . . . . . . . . . . .85$

Schulz Ranch Sandstone Member ..... 85

Pleasants Sandstone Member........... 86

Paleocene ........................................... 89

Silverado Formation .......................... 89

Eocene ............................................ 90

Santiago Formation .......................... 90

Eocene(?) to Miocene ................................ 92

Sespe and Vaqueros Formations, undiffer. entiated .................................. 92

Miocene ........................................... 93

Topanga Formation ........................... 93

Pliocene

Fernando Formation ......................... 96

List of microfossils

Miocene................................................... 97

Topanga Formation ........................... 97

El Modeno Volcanics ............................... 97

Monterey Shale ................................... 97

Puente Formation................................ 97

La Vida Member...................... 97

La Vida and Yorba Members, undifferentiated

98
Supplemental information-Continued

List of microfossils-Continued

Miocene-Continued

Puente Formation-Continued

Yorba Member

La Vida and Yorba Members undifferentiated

Pliocene...........-.-.- 99

Fernando Formation........................... 99

Megafossil localities

Late Cretaceous......................... 99

Ladd Formation ................ 99

Baker Canyon Conglomerate Member 99

Holz Shale Member ............... 100

Williams Formation............................... 101

Schulz Ranch Sandstone Member ....- 101

Pleasants Sandstone Member........... 101

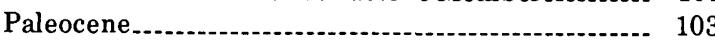

Silverado Formation ......................... 103

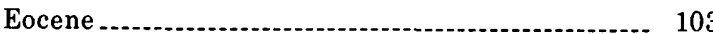

Santiago Formation........................ 103

Eocene( ?) to Miocene

Sespe and Vaqueros Formations, undifferentiated.

104

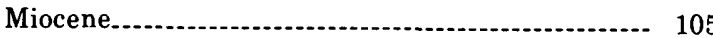

Topanga Formation

Pliocene........

Fernando Formation

Lower member ......................... 106

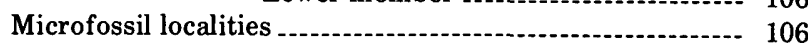

Miocene-(-...- 106

Topanga Formation ........................... 106

El Modeno Volcanics ............................. 107

Monterey Shale ................................ 107

Puente Formation

Pliocene....................................................... 107

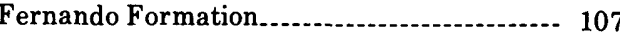

Lower member ............................ 107

Index

\section{ILLUSTRATIONS}

[Plates are in pocket]

FronTISPIECE. View north up Ladd Canyon.

Plate 1. Geologic map of the northern Santa Ana Mountains.

2. Structure sections $A \cdot C, A \cdot H, B \cdot N ; A \cdot K, E \cdot L, H \cdot O, L \cdot Q$.

3. Structure sections $G \cdot J, R \cdot S, L \cdot P, U \cdot W, M \cdot F, U \cdot V, T \cdot X$.

4. Columnar sections of the lower part of the Silverado Formation.

FIGURE 1. Outline map of Los Angeles basin

2. Generalized physiographic map of northern Santa Ana Mountains showing geographic names............................. 4

3. Generalized stratigraphic section of northern Santa Ana Mountains area

4. Photograph showing siltstone and sandstone of the Bedford Canyon Formation .

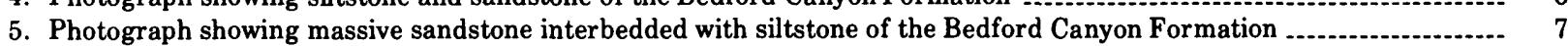

6. Photomicrographs of coarse-grained lithic graywacke in the Bedford Canyon Formation ................................... 8

7. Photograph showing redeposited quartzite and siltstone boulders and cobbles in the Santiago Peak Volcanics........... 9

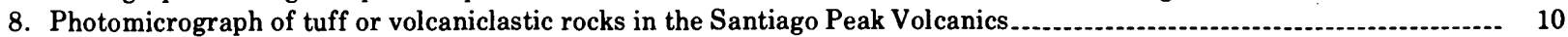

9. Photograph showing sedimentary features of graded lens in the Holz Shale Member of the Ladd Formation ........... 16

10. Photograph showing contact between the Holz Shale Member of the Ladd Formation and overlying Schultz Ranch Sandstone Member of the Williams Formation.

11. Photograph showing contact between the Schulz Ranch Sandstone and overlying Pleasants Sandstone Member of the Williams Formation. 
Page

12. Photograph showing the Claymont Clay Bed on Gypsum-Fremont Canyon divide .

13. Photomicrographs of the Claymont Clay $\ldots$

14. Photomicrographs of the Claymont Clay

15-19. Photographs showing

15. Contact between the Santiago and Silverado Formations

16. Basal conglomerate of the undifferentiated Sespe and Vaqueros Formations overlying the Santiago Formation .......... 33

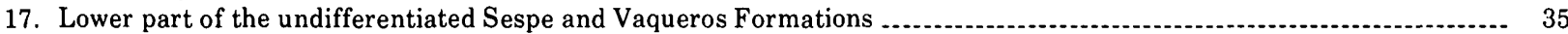

18. Basal beds of the Topanga Formation

19. Unconformity between the La Vida Member of the Puente Formation and the undifferentiated Sespe and Vaqueros Formations

20. Schematic map showing thickness of sandstone in members of the Puente Formation

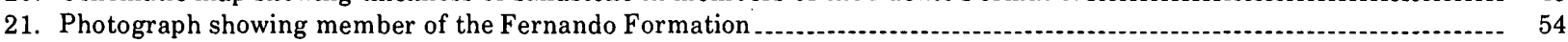

22. Photograph showing La Habra Formation unconformably overlain by older alluvium...................................... 59

23. Photograph showing terraces along Silverado and Santiago Creeks

\section{TABLES}

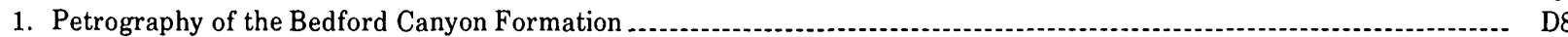

2. Petrography of the Santiago Peak Volcanics and related intrusive rocks

3. Petrography of the Ladd Formation .........

4. Petrography of the Williams Formation

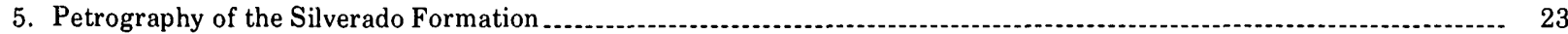

6. Petrography of the Santiago Formation 


\title{
GEOLOGY OF THE EASTERN LOS ANGELES BASIN, SOUTHERN CALIFORNIA
}

\section{GEOLOGY OF THE NORTHERN SANTA ANA MOUNTAINS, CALIFORNIA}

\author{
By J. E. SCHOellHAMER, J. G. VEDDER, R. F. YeRKES, and D. M. KINNEY
}

\begin{abstract}
The Santa Ana Mountains expose one of the most complete strati. graphic sections in coastal southern California, and much of the section contains distinctive rocks and diagnostic fossils.

The section includes a basement complex of crystalline and semicrystalline rocks of Mesozoic age, unconformably overlain by as much as $5,200 \mathrm{~m}$ of Upper Cretaceous and Cenozoic clastic strata ranging in composition from organic shale to boulder conglomerate. The basement consists of the marine clastic Bedford Canyon Formation of Middle Jurassic age and is perhaps 5,500 m thick; the Upper Jurassic(?) and Lower(?) Cretaceous Santiago Peak Volcanics, 790 $\mathrm{m}$ thick; and extensive middle Cretaceous quartz plutonite bodies. The superjacent sedimentary deposits are mostly marine and of Late Cretaceous, Paleocene, Eocene, Miocene. Pliocene, and Pleistocene age. In addition, nonmarine units interfinger with marine, especially just above major unconformities.
\end{abstract}

The northeastern, highest part of the Santa Ana Mountains is a sharply folded anticline, plunging northwest and having a downfaulted, narrow northeast limb and a similarly truncated nose. The downthrow to the north, on the Whittier fault zone, is variable, with an apparent stratigraphic separation of about $900 \mathrm{~m}$. That to the northeast, on the Elsinore fault zone, may be slightly greater.

The low western parts of the mountains are underlain by rocks that are only moderately folded, broken by numerous northwest- to north-trending normal faults. A complex, horstlike positive structure extends east-west along lower Santiago Creek. The broad Loma Ridge syncline farther south underlies much of the southern part of the mapped area. At the west edge of the mountains, the post-middle Miocene formations thicken slightly westward toward the subsiding Los Angeles basin, though both thickening and subsidence reverse directions in the subsurface anticlinal Anaheim nose, 5 or $6 \mathrm{~km}$ west of the mountains.

The geologic map, structure sections, and supporting data show that the geologic record of the northern Santa Ana Mountains characterizes that of the northern Peninsular Ranges, including the San Joaquin Hills to the south and southwest, the Los Angles basin to the west, the Puente Hills to the north, and the Perris Block to the east. Thus, the mountains furnish evidence of regional significance: the boundary between basement and superjacent sedimentary rocks is of Early or middle Cretaceous age; northeastward transgression of Paleocene strata onto successively older units records an early Tertiary southwestward tilt of the mountain mass, and northward and eastward onlap of successively younger strata onto the basement surface is interptreted as additional evidence of an extensive, persistent early Tertiary peneplain; the tilting of the mountain mass and associated deformation continued to middle Miocene time, when relative depression of the Los Angeles basin began; and continuing deformation produced pronounced erosional unconformities in upper Miocene, Pliocene, and upper Pleistocene strata.

\section{INTRODUCTION}

The Los Angeles basin is the world's most prolific oil-producing sedimentary basin in relation to its small size. Detailed geologic mapping of the eastern margin of the basin was begun in the northern Santa Ana Mountains by the U. S. Geological Survey in 1948. The objective was to furnish modern large-scale geologic maps of a part of the basin in which many key stratigraphic units are exposed and to prepare definitive lithologic and paleontologic descriptions in order to provide a partial basis for understanding the exceptional petroleum potential. The mapping program was later expanded to cover the Puente Hills to the north and northwest and the San Joaquin Hills-San Juan Capistrano area to the south.

This paper reports on the geology of the northern Santa Ana Mountains. Other parts in this series are Professional Paper 420-A, Geology of the Los Angeles basin-an introduction (Yerkes and others, 1965); 420-B, Geology and oil resources of the eastern Puente Hills area, southern California (Durham and Yerkes, 1964); and 420-C, Geology and oil resources of the western Puente Hills area, southern California (Yerkes, 1972) (fig. 1).

The northern Santa Ana Mountains dominate the northern Peninsular Ranges of coastal southern California and form the southeast margin of the Los Angeles basin. The mountains expose the most complete section of the late Mesozoic and Cenozoic se. quence that underlies the north part of the Peninsular Ranges physiographic province. Comparisons of the northern Santa Ana Mountains section and its relations to other parts of the basin are given in Chapter A of this Professional Paper (Yerkes and others, 1965).

This report describes the geology of the Black Star and Orange 7.5-minute quadrangles and the north halves of the El Toro and Tustin 7.5-minute quadrangles (fig. 1). Fieldwork was done in 1948-53; revisions of the northeast part of the Black Star quadrangle were made in 1954 and 1976.

A draft of the report was written in 1955 and first revised in 1959-60, using data from surface exposures and from wells drilled before 1959. Some later data collected up to June 1976 have been made a part of the report during final revision. The list of wells includes 
only those used in preparation of this report, and the nomenclature of the operators is that in use in 1958.

\section{ACKNOWLEDGMENTS}

It is a pleasure to acknowledge the scientific contributions of the U. S. Geological Survey colleagues Patsy B. Smith, M. C. Israelsky, G. Edward Lewis, T. H.
McCulloh, Ellen J. Moore, W. P. Popenoe, L. G. Schultz, Ralph Stewart, A. O. Woodford, and W. P. Woodring during the course of the field and laboratory work leading to completion of this study. The final manuscript was improved as a result of suggestions made during critical reviews by T. H. McCulloh and George W. Moore. We single out for special mention the contributions of A. O. Woodford, who participated

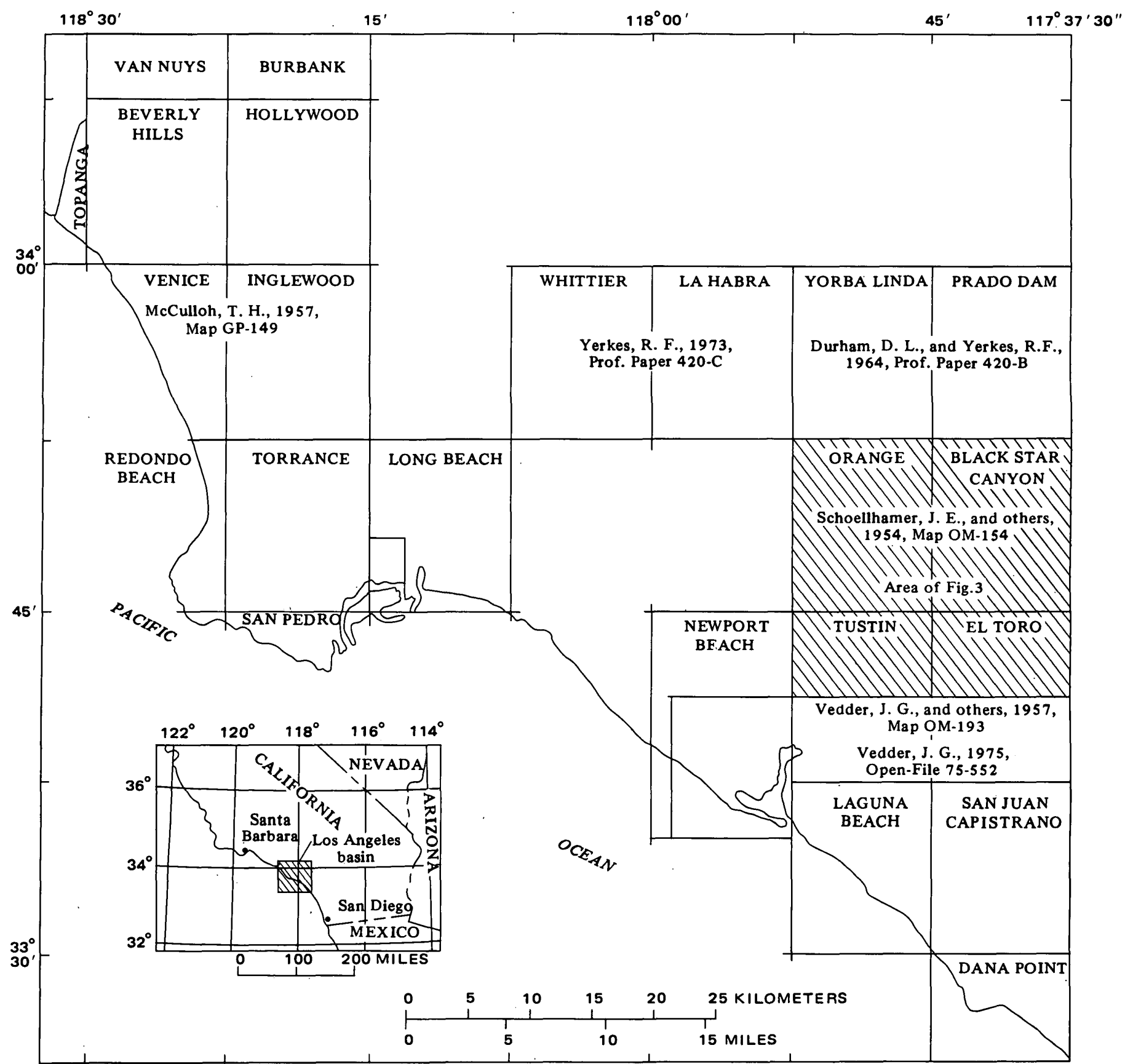

FIGURE 1.- Outline map of the Los Angeles basin. Area mapped for this investigation is patterned by diagonal lines; names of pertinent 7.5. minute quadrangles are shown. Entire area included in an introduction to the structural and stratigraphic history of the Los Angeles basin (Yerkes and others, 1965). 
in many aspects of the research during its progress and who, through innumumerable discussions, was involved in the generation of many of the concepts presented here. Without the help of Ellen J. Moore and Rose M. Trombley in preparing the text for editing, the report in its present form probably would not have been completed.

The subsurface data used in compiling parts of this report were furnished by oil companies and consulting geologists active in the Los Angeles area; their cooperation and help is gratefully acknowledged. These data and discussions with these geologists provided significant stratigraphic and structural information unobtainable elsewhere. The California Division of Oil and Gas furnished data on some of the older wells drilled in the area. All of these data were used in compiling the structure sections (pls. 2 and 3). In the 1976 revision especially important supplementary information was furnished by L. J. Simon, F. R. Goodban, and J. M. Gibson of Texaco, Inc., R. A. Davis of Union Oil Company, and M. J. Castro of Casex.

The cooperation of the many landowners who granted permission to enter their property is also gratefully acknowledged. Special thanks are due Mr. W. B. Hellis, formerly manager of the Irvine Ranch, for permission to enter this ranch, which covers nearly 50 percent of the mapped area. The California Division of Forestry and the U. S. Forest Service furnished access to many of the fire roads in parts of the area. During the fall and winter of 1949-50, J. F. Richmond prepared a geologic report on a $38-\mathrm{km}^{2}$ area along Burruel Ridge (fig.2): His report was published by the California Division of Mines (Richmond, 1952), and the map presented here for that area is essentially the same as his. Field assistance was furnished by A. E. Altinli, visiting from Turkey in 1948, and nomenclatural revisions of Eocene mollusks by C. R. Givens, Nicholls State University, Louisiana. William Otto, formerly preparator at the California Institute of Technology, guided the authors to a fossil vertebrate locality in the undifferentiated Sespe and Vaqueros Formations south of Bolero Lookout and assisted in collecting the remaining available material. T. A. Downs of the Los Angeles County Museum arranged to loan material previously collected from this locality. C. H. Gray, Jr., of the California Division of Mines and Geology, assisted in mapping the northeast part of the area. After the publication of the preliminary map (Schoellhamer and others, 1954) Donald L. Lamar, then a Fellow at the University of California at Los Angeles, mapped parts of the northeast corner of the Black Star Canyon quadrangle and the adjoining area to the east; his geologic information necessitated some map revisions in this area.

\section{JURASSIC SYSTEM MIDDLE JURASSIC SERIES \\ BEDFORD CANYON FORMATION}

The oldest exposed rock unit in the northern Santa Ana Mountains is the Bedford Canyon Formation named by Larsen (1948) for exposures in Bedford Canyon. The Bedford Canyon is composed chiefly of slightly metamorphosed, locally slaty siltstone and graywacke, with minor amounts of pebble conglomer. ate and limestone (fig. 3). The type locality is in Bedford Canyon, $6 \mathrm{~km}$ east of the map area. The Bedford Canyon extends west and northwest from its type into upper Silverado and Ladd Canyons ( $\mathrm{pl} .1$ ) and occurs in the subsurface at least as far as the west edge of the northern Santa Ana Mountains (Texas Co. well, Irvine NCT-2 No. 1, and other wells south of the map area). The base of the formation is not exposed. South of Oak Flat the Bedford Canyon Formation is overlain unconformably, with as much as a $90^{\circ}$ discordance, by the Santiago Peak Volcanics; elsewhere it is intruded by quartz plutonite and gabbro of the Southern California batholith (Larsen, 1948). The prevailing dip is compli. cated by minor folds and shear zones (fig. 4).

In Silverado Canyon, a traverse suggests a thickness of $5,500 \mathrm{~m}$. The actual thickness may be much less, as indicated by isoclinal folding (fig. 5) and possible overturning (Buckley and others, 1975, p. 299-300). Estimates along the traverse suggest proportions of 59 percent siltstone, 40 percent graywacke, and 1 percent conglomerate and limestone.

The graywacke is gray and made up of angular grains up to $2 \mathrm{~mm}$ in diameter that are approximately onethird quartz grains, one-third rock fragments, and one-third matrix (fig. 6; table 1). The beds are commonly a meter or less thick, separated by metasiltstone layers 5 to $10 \mathrm{~cm}$ thick, and are seamed with quartz veinlets.

The siltstone breaks into small blocks bounded by the bedding planes, slaty cleavage, and joints perpendicular to the bedding. The rock is reddish gray to bluish black and composed of particles whose maximum size ranges from 0.005 to $0.1 \mathrm{~mm}$ in the samples studied. Slivers of muscovite mark irregular layers of stratification (table 1).

At places thin lenses of resistant pebble conglomerate are sporadically interbedded with the sandstone and siltstone. One pebble bed in upper (eastern) Silverado Canyon is $8 \mathrm{~m}$ thick. The pebbles are as much as $3 \mathrm{~cm}$ in diameter, subrounded to rounded, and polished. They are light- to dark-gray quartzite, chert, and indurated argillite. The matrix is recrystallized ar- 
gillaceous material that weathers brown.

Limestone outcrops east of the map area yield fossils diagnostic of Callovian (Middle Jurassic) age (Silberling and others, 1961; Imlay, 1963). Some of the lime-

stone bodies of the Bedford Canyon Formation have been resedimented, and the allochthonous fossils in them set a maximum age limit (Moran, 1976, p. 2040-2041).

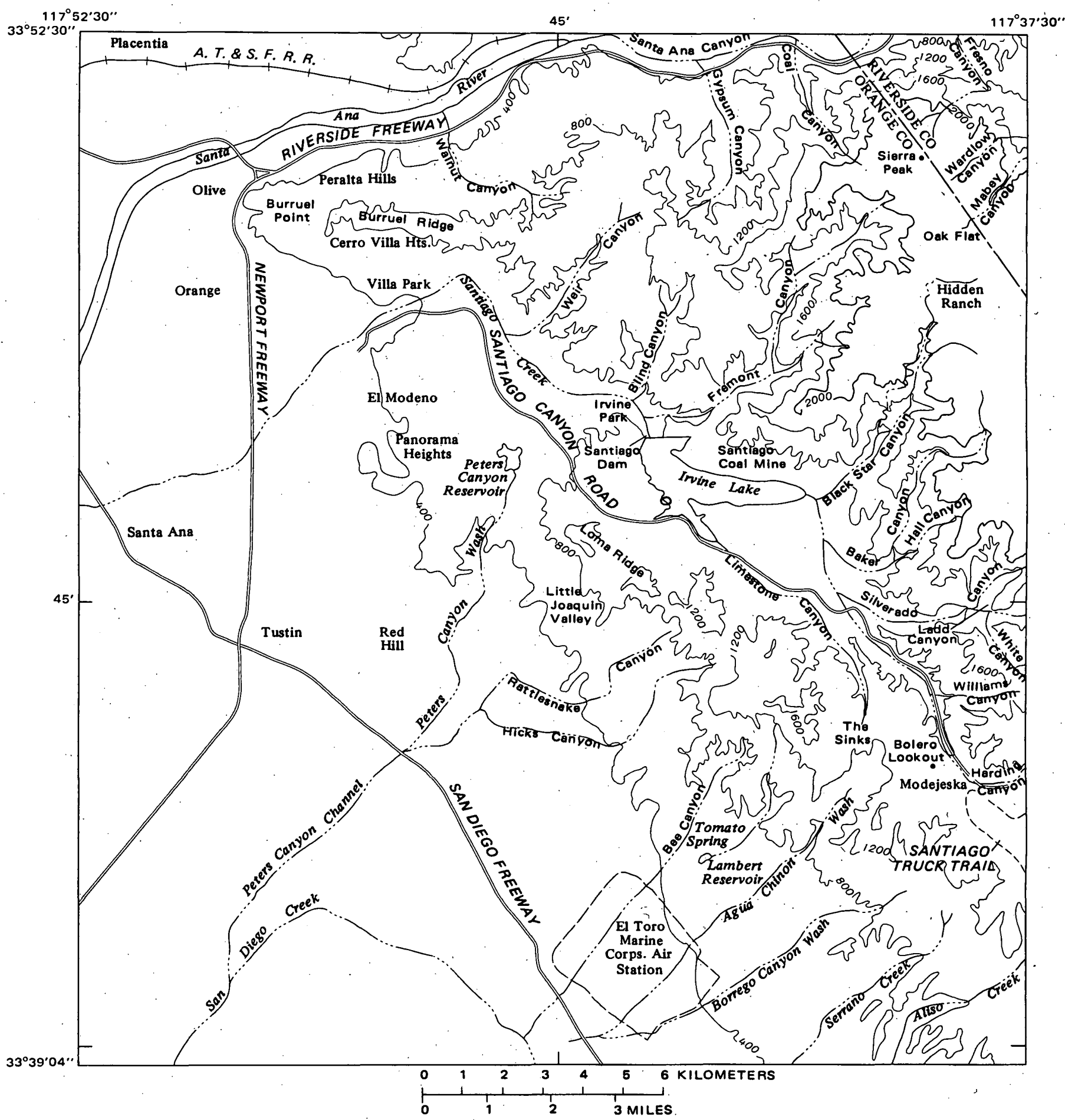

FIGURE 2.- Generalized physiographic map of the northern Santa Ana Mountains, showing geographic names. 


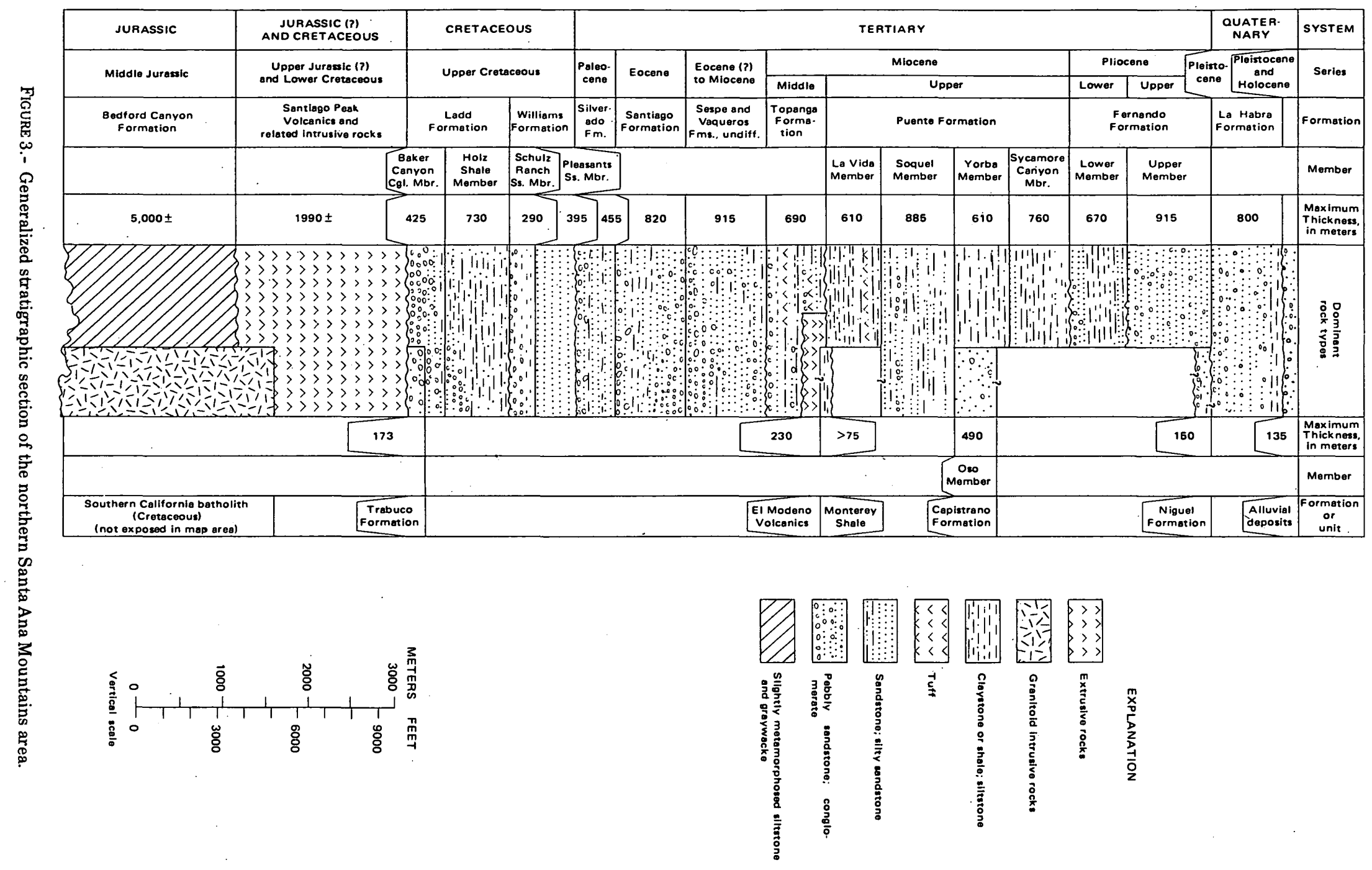

20 


\section{JURASSIC(?) AND CRETACEOUS SYSTEMS}

UPPER JURASSIC(?) AND

LOWER(?) CRETACEOUS SERIES

SANTIAGO PEAK VOLCANICS AND RELATED INTRUSIVE ROCKS

The oldest igneous rocks exposed in the northern Santa Ana Mountains consist of at least $790 \mathrm{~m}$ of mildly metamorphosed extrusive volcanic rocks. Andesitic flows and flow breccia, greenstone, dacitic flows, volcanic "slate chip" breccia, and minor bedded tuff are associated with quartz-bearing and other intrusive rocks. Larsen (1948, p. 23) named this dominantly extrusive sequence the Santiago Peak Volcanics after their representative exposures on Santiago Peak, $10 \mathrm{~km}$ southeast of the map area.
These volcanic rocks rest with angular discordance upon a surface of irregular relief cut across the Bedford Canyon Formation. They are discontinuous because of dismemberment by the Southern California batholith and because of their unconformable cover of younger sedimentary rocks. East of Black Star Canyon, they form a westward-dipping band 0.5 to $1.5 \mathrm{~km}$ wide. They extend around the northern end of the Santa Ana Mountains and are exposed along the northeastern flank of the mountains (Gray, 1951). The distribution of the volcanic rocks southeast of the map area (Larsen, 1948, p. 1) shows that they are mostly remnants of a thick and once-widespread sheet. The Santiago Peak Volcanics underlies approximately $15 \mathrm{~km}^{2}$ of the map area. Its western limit is unknown, but the volcanic

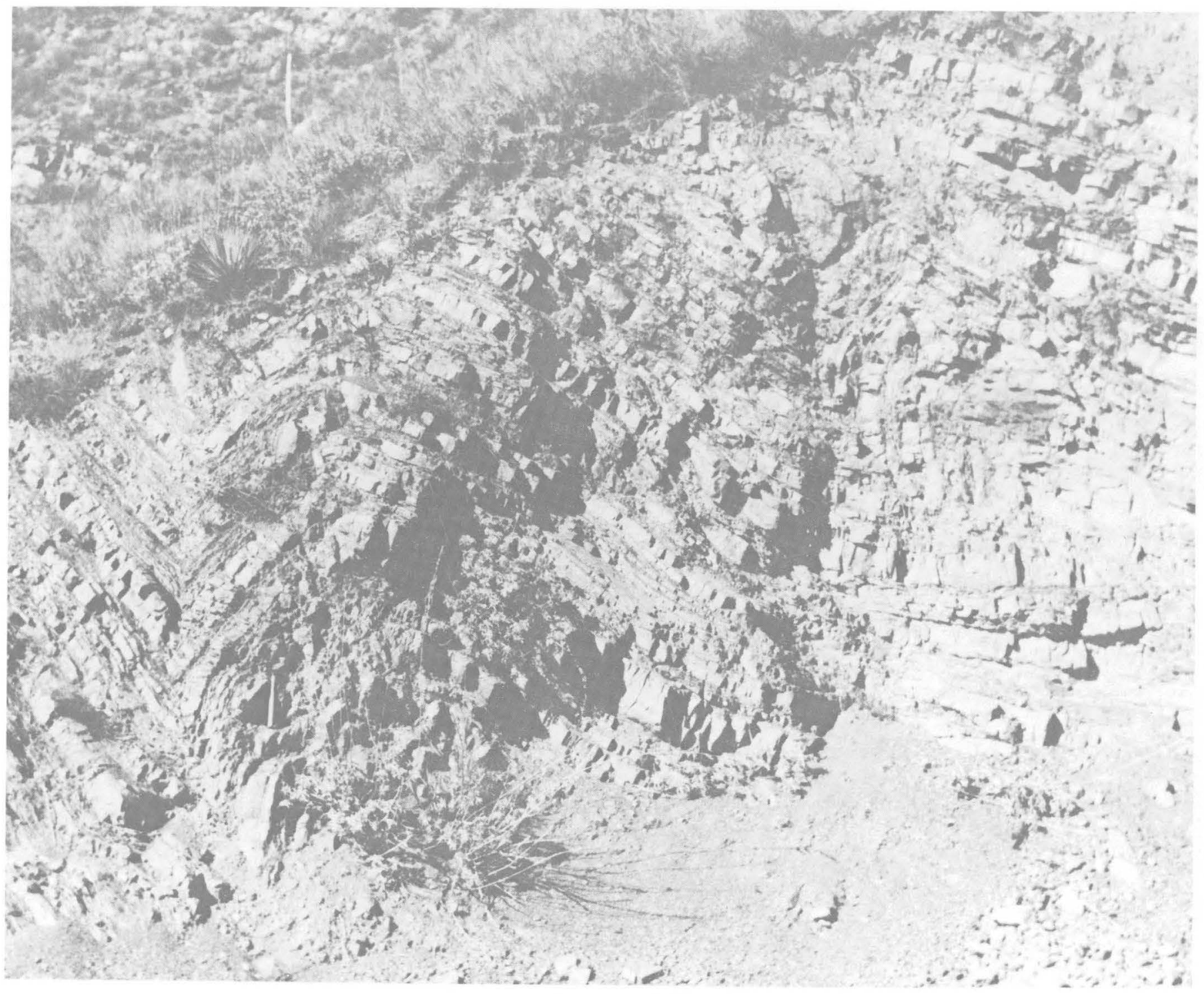

FIGURE 4.- Siltstone and sandstone of the Bedford Canyon Formation in a cut on Bedford Peak Truck Trail in Alberhill quadrangle, directly east of map area. Note hammer at lower left. 
rocks extend westward from the outcrop area for several kilometers beneath younger sediments. The Morton and Sons well, El Toro No. 14-1, $3 \mathrm{~km}$ north of the town of El Toro and about $3 \mathrm{~km}$ directly south of the map area, cored hard, dense metavolcanic rocks similar to those of the Santiago Peak Volcanics at 1,986 m (Schoellhamer and Vedder, 1975).

The formation is probably about $790 \mathrm{~m}$ thick in and just north of Silverado Canyon, though only the basal $180 \mathrm{~m}$ is well exposed.

Several rock types, not differentiated on the geologic map, have been recognized. Throughout the map area the lower part of the Santiago Peak Volcanics is made up of rock types which are distinctive and relatively resistant to weathering. These basal rocks consist of vol- canic "slate chip" breccia and an overlying bone-white dacite(?) flow. Succeeding them is a thick, massive section consisting of a repetitious sequence of altered andesite flows, flow breccia, and agglomerate. In the Sierra Peak area near the northern limit of the formation, one or more large bodies of intrusive rock are present. These rocks are quartz bearing and porphyritic, and locally tourmalinization is conspicuous. Numerous small dikes and sills of quartz-free andesitic rocks intrude the volcanic rocks throughout the map area.

\section{VOLCANIC "SLATE CHIP" BRECCIA}

Almost everywhere, the basal $15 \mathrm{~m}$ or so of the Santiago Peak Volcanics consist of breccia. In Silverado

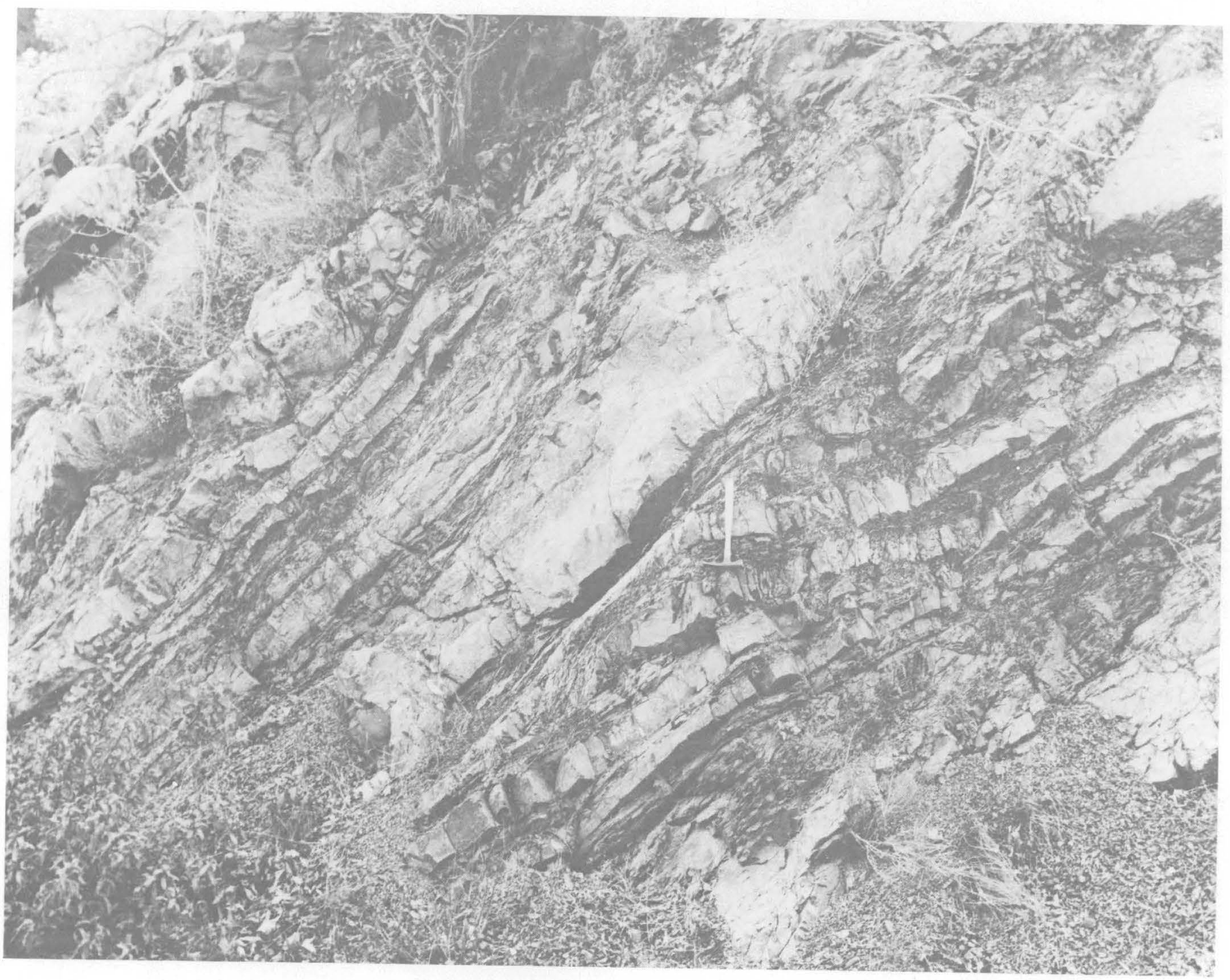

FIGURE 5.- Massive sandstone interbedded with darker laminated fractured siltstone of the Bedford Canyon Formation, showing an isoclinal fold cut by shear (just above hammer handle) in roadcut on Bedford Peak Truck Trail. 
Canyon, $700 \mathrm{~m}$ east of its junction with Ladd Canyon, the lowest $1.5 \mathrm{~m}$. of this breccia is largely made up of boulders and cobbles derived from the underlying Bedford Canyon Formation imbedded in a silicified, sandy, altered igneous matrix (fig. 7). The boulder-cobble breccia grades upward into the "slate chip" breccia typical of the lowest part of the formation. Here it is $15 \mathrm{~m}$ thick and is made up of 50 percent loosely packed fragments of indurated siltstone and graywacke averaging $5 \mathrm{~mm}$ in diameter in a completely silicified igneous matrix (table 2).
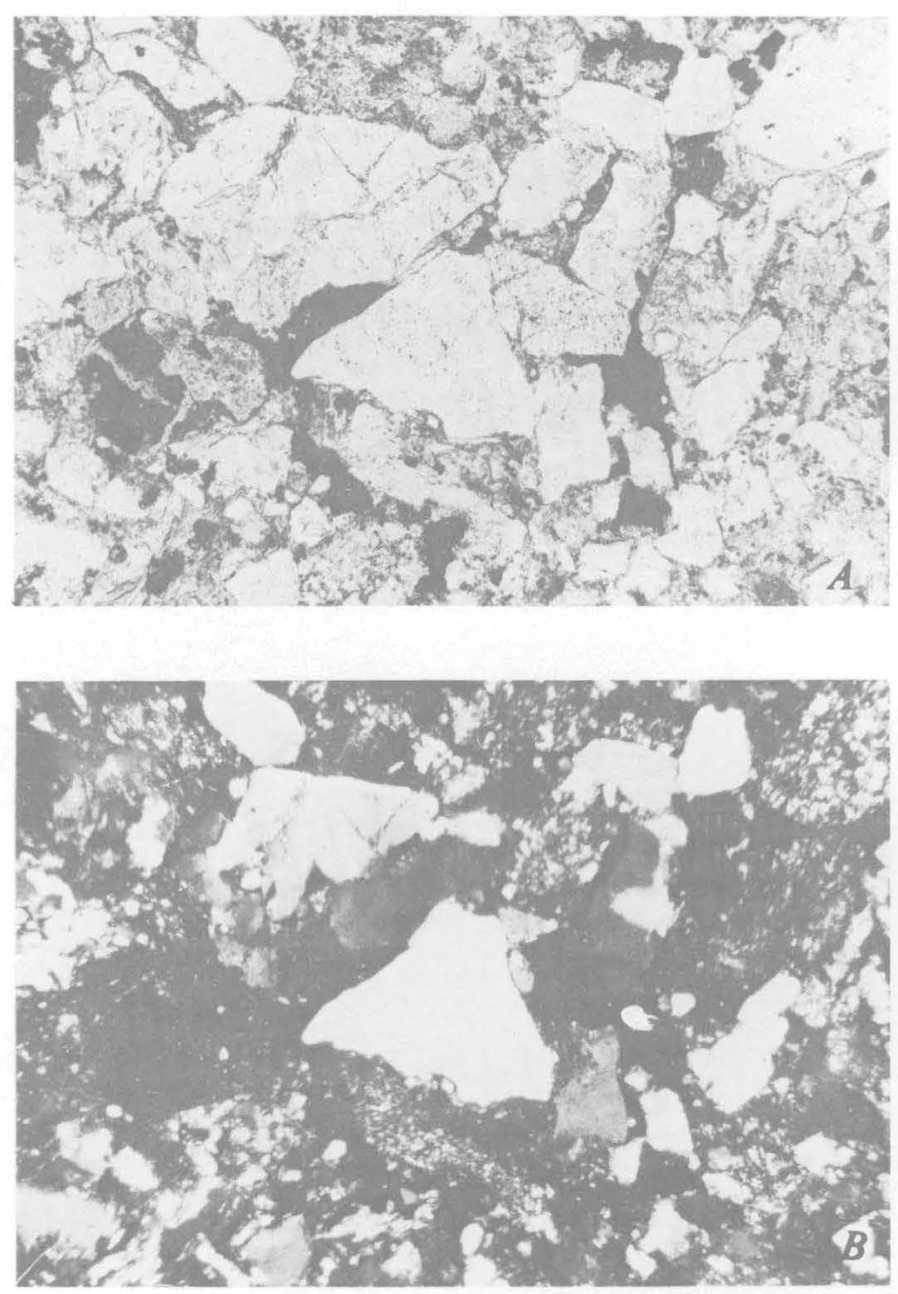

FIGURE 6.- Photomicrographs of coarse-grained lithic graywacke in the Bedford Canyon Formation; angular quartz grains in chlorite matrix. A, Plane light; $B$, Crossed nicols.

TABLE 1.-Petrography of the Bedford Canyon Formation

\begin{tabular}{|c|c|c|c|}
\hline Rock type & Composition & $\begin{array}{l}\text { Volume } \\
\text { percent }\end{array}$ & Comments \\
\hline Graywacke. & \multicolumn{2}{|c|}{$\begin{array}{l}\text { Rock fragments _. } \\
\text { Quartz } \\
\text { Sodic plagioclase } \\
\text { Chlorite } \\
\text { Muscovite... } \\
\text { Matrix }\end{array}$} & Chloritic, micaceous, and clayey. \\
\hline \multirow[t]{2}{*}{ Siltstone. } & Quartz............ & $35-60$ & \multirow[t]{2}{*}{$\begin{array}{l}\text { Matrix seems to be sericite, chlorite, and clay } \\
\text { minerals in a silicic cement. }\end{array}$} \\
\hline & $\begin{array}{l}\text { Muscovite } \\
\text { Rock fragments }\end{array}$ & $\begin{array}{r}10-15 \\
25-60\end{array}$ & \\
\hline
\end{tabular}

\section{DACITE(?) FLOW}

Overlying the volcanic "slate chip" breccia is a distinctive, hard, bone-white, deeply altered and silicified dacite(?) flow with large glassy quartz phenocrysts. In Silverado Canyon this unit is approximately $10 \mathrm{~m}$ thick; elsewhere it reaches $15 \mathrm{~m}$ in thickness and commonly forms rugged, angular outcrops that disintegrate into white talus slopes. Larsen $(1948$, p. 25) as well as Bellemin and Merriam (1958, p. 217) termed this rock a rhyolite. On the basis of microsopic analysis it is believed to be of dacitic composition; possibly it is a silicified dacitic tuff.

TUFF

Thoroughly altered bedded tuff was sampled from two localities near the base of the Santiago Peak Volcanics. One locality is near Williams Canyon in the southeast part of the map area, the other on the Main Divide motorway $8.9 \mathrm{~km}$ farther north. Both bodies of tuff are contaminated with detrital rock and quartz grains; each contains plagioclase in microlites and larger fragments (fig.8). The tuff beds are soft, crumbly and easily eroded.

\section{ANDESITE FLOWS AND FLOW BRECCIAS}

Andesite flows and flow breccias are the commonest and most wide-spread rocks in the Santiago Peak Volcanics. These rocks are best developed in the region drained by Silverado and Ladd Canyons and are not prominent in other parts of the map area. In Silverado Canyon the white dacite(?) flow is overlain by more than $60 \mathrm{~m}$ of andesitic breccia containing chips and pebbles of redeposited volcanic and sedimentary rocks. In Ladd Canyon the breccia is extensive and forms steep canyon walls at least a hundred meters high. Elsewhere, the dacite(?) flow is overlain by a repetitious sequence of deeply altered grayish-green or reddish to lavender porphyritic andesite flows, locally brecciated or agglomeratic. Fresh unweathered rock is commonly light to dark greenish gray. Differential weathering of the brecciated and agglomeratic rocks produces rough, nodular surfaces. Other structural features such as flow banding and vesicularity are discernible rarely and only on weathered surfaces. Surface staining by iron oxides is thought to be derived from pyrite.

Plagioclase phenocrysts in the andesite average 0.3 $\mathrm{mm}$ in length, with a $4 \mathrm{~mm}$ maximum; they commonly range from $\mathrm{An}_{35}$ to $\mathrm{An}_{65}$ and typically are partly altered to albite, calcite, chlorite, quartz, or illite. Augite seems to have been a common original mineral that was altered to chlorite. In one sample, 6 percent is hornblende after augite(?) and 18 percent chlorite after hornblende or augite. More commonly, however, the andesite is more complexly altered to greenstone ( table 2). 
DACITE PORPHYRY

At least one large mass of dark-gray-green quartzbearing porphyritic rock intrudes the Santiago Peak Volcanics in the area north and east of Sierra Peak. This body, called quartz porphyry Larsen (1948, p. 27), may be related to his Temescal Wash Quartz Latite Porphyry (Larsen, 1948, pp. 36-39). The composition of the intrusion near Sierra Peak, based on micrometric analysis, is clearly dacitic, and the rock is best called a dacite porphyry. The rock is the most resistant of the igneous rocks in the area, and the larger bodies form bold, angular outcrops with nearly vertical contacts.

Exposures of this dacite porphyry are generally light to dark yellowish brown in color. Fresh specimens are light to dark greenish gray, hard and dense, and porphyritic, consisting of closely packed quartz and feldspar phenocrysts in a much finer grained groundmass. The phencrysts of quartz and plagioclase average $1 \mathrm{~mm}$ and are up to $8 \mathrm{~mm}$ long. Alteration of the feldspar phenocrysts locally gives the rock a lightcolored chalky appearance.

Many small dikes and sills of altered quartz-free andesitic rocks cut both the Santiago Peak Volcanics and the underlying Bedford Canyon Formation. In the

TABLE 2.-Petrography of the Santiago Peak Volcanics and related intrusive rocks

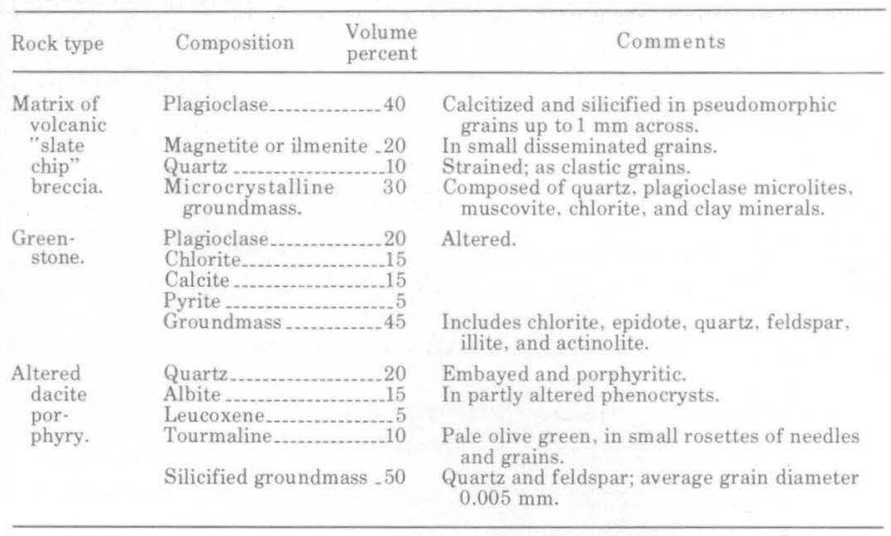

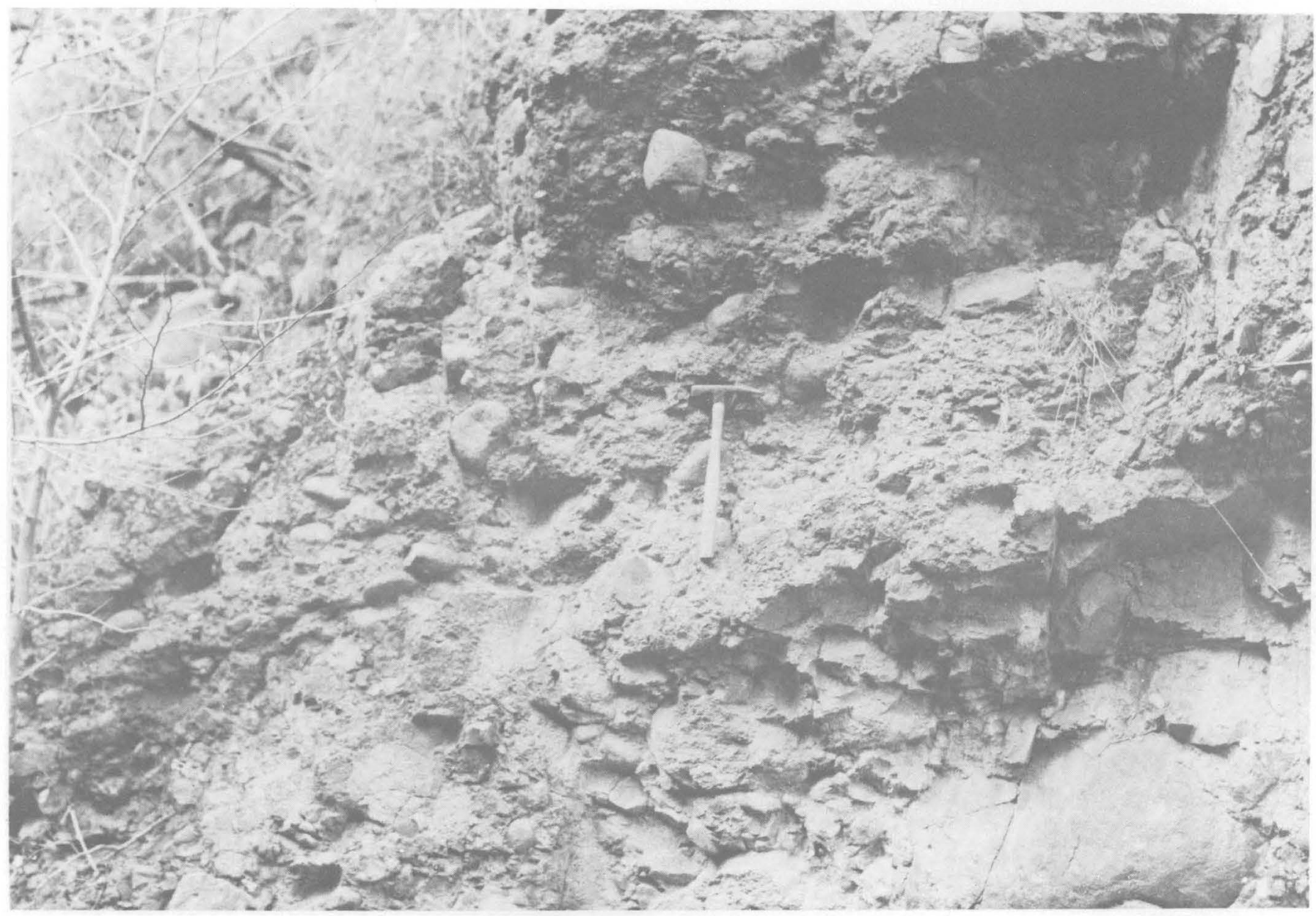

FIGURE 7.- Redeposited quartzite and siltstone boulders and cobbles in the basal part of the Santiago Peak Volcanics, south wall of Silverado Canyon. 
Bedford Canyon Formation most of the intrusive bodies occur near the contact with the overlying Santiago Peak. Volcanics and are probably associated with old faults. No notable differences are apparent between the dikes in the two formations. Small chips charac- teristic of the Bedford Canyon are included in the intrusive bodies.

Both the quartz-free and the quartz-bearing intrusive rocks are similar texturally and mineralogically to the Santiago Peak Volcanics and display much the same alteration and recrystallization. Larsen (1948, p. 27) shows that these intrusive rocks are themselves intruded by the batholith. Presumably these prebatholithic rocks are genetically related to and in part contemporaneous with the Santiago Peak Volcanics.

\section{ALTERATION AND METAMORPHISM}

Mild metamorphism, deuteric alteration tourmalinization, and epidotization have had varying effects upon the Santiago Peak Volcanics and the related intrusive rocks throughout the area.

Widespread mild metamorphism of the volcanic rocks and their related intrusive rocks has masked the deuteric alterations, such as chloritization and cavity

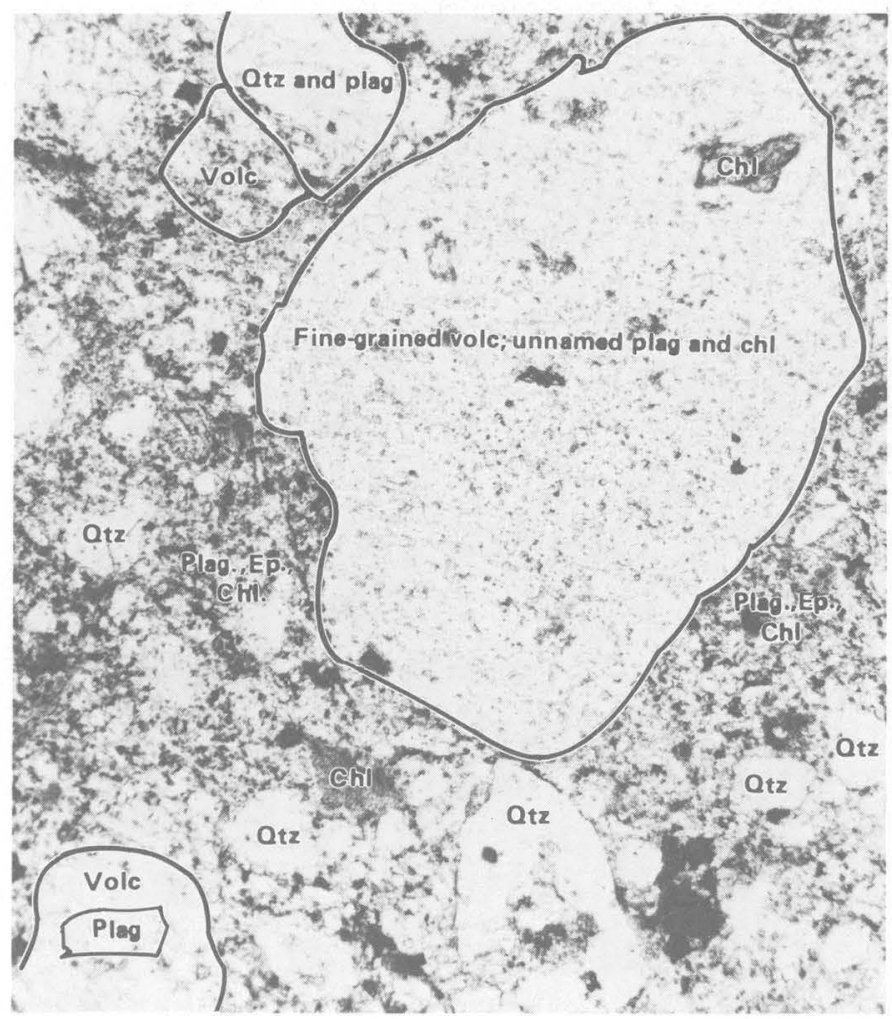

Figure 8.- Photomicrograph of tuff or volcaniclastic rocks in the Santiago Peak Volcanics, showing numerous angular fragments of volcanic and sedimentary rocks. From bed $1+\mathrm{m}$ thick in Williams Canyon. filling, that may have accompanied their deposition. Chief among the effects of metamorphism is the replacement of the feldspar phenocrysts by albite, quartz, chlorite, epidote, and calcite, or illite and calcite. These replacements were accompanied by recrystallization of the groundmass to microcrystalline mosaics of quartz, albite, and the characteristic prochlorite. The ferromagnesian minerals commonly are completely replaced, often pseudomorphically, by chlorite or chlorite and calcite. Pseudomorphs of hornblende after augite, characteristic of greenstone of more advanced grade, are uncommon in the Santiago Peak rocks of this area. Ilmenite was identified with certainty in only a few samples, but pyrite and leucoxene are present in minor amounts. Metacrystalline quartz is widespread in the groundmass of many of the rocks, and occasionally it is euhedral. Mantles of secondary quartz typically enclose the phenocrysts, and veinlets of calcite, epidote, and clinozoisite are common in the more highly altered rocks.

\section{TOURMALINIZATION}

A broad belt of tourmalinized rocks occurs in the quartz-bearing intrusive rocks southwest, west, and northwest of Sierra Peak. Three widely separated samples were collected along the east boundary of sec. $1, \mathrm{~T}$. 3 S., R. 8 W. Two samples, the most extensively altered, contain 39 and 10 percent tourmaline, and the latter contains several fragments of siltstone that have been extensively tourmalinized along with the host rock. In this rock the replacement of feldspar by tourmaline is incomplete (table 2). In the other sample the feldspar apparently has been completely replaced, and the grayish-green tourmaline occurs in radial patches of needles that commonly pierce the intimately sutured quartz grains that make up the groundmass. Primary subhedral phenocrysts of quartz as large as $1.5 \mathrm{~mm}$ in maximum dimension are still preserved. The grain size of the groundmass quartz averages $0.07 \mathrm{~mm}$ in maximum dimension. Relict plagioclase phenocrysts indicate that the completely tourmalinized rock represented by this sample probably was derived from the quartz-bearing intrusive rock of the Sierra Peak area.

A sample from the quartz-free porphyritic andesite flow rock on the ridge west of the head of Wardlow Canyon ( $\mathrm{SE}^{1 / 4}$ sec. 6 , T. 4 S., R. 7 W.) contains 1.5 percent tourmaline.

\section{EPIDOTIZATION}

A small zone of extensively epidotized volcanic rocks is present in the roadcuts of the Corona Skyline Drive where it descends the northeastern flank of the Santa Ana Mountains. The andesitic host rock in this zone 
contains from 5 to 90 percent epidote, commonly as discrete grains in a partly to wholly recrystallized groundmass, and occasionally as sporadic aggregates of grains associated with calcite in altered phenocrysts or as small veinlets with clinozoisite and calcite.

\section{AGE AND CORRELATION}

Fossils have not been found in the Santiago Peak Volcanics within the map area. The formation is younger than the Callovian (Middle Jurassic) part of the Bedford Canyon Formation and older than the Turonian (Late Cretaceous) beds at the base of the unconformably overlying Trabuco and Ladd Formations. Apparent radiometric ages from the Santiago Peak Volcanics in the Silverado Canyon area are $131 \pm 2.6$, $106 \pm 2.3$, and $85 \pm 2$ million years (Cólburn, 1973, p. 58 ) and $155 \pm 15.5$ million years at Santiago Peak (Bushee and others, 1963, p. 803-804). Unconformably overlying Turonian beds in Silverado Canyon imply that the $85 \mathrm{~m}$.y. date is too young. The stratigraphic relations in the northern Santa Ana Mountains suggest an age of Late(?) and Early(?) Cretaceous.

The formation resembles parts of the andesitebearing Alisitos Formation of Baja California, which is of Aptian and Albian (Early Cretaceous) age according to Allison (1955) and Gastil and others (1975). Slate and argillite interbedded with rocks assigned by Fife and others (1967, p. 300-303) to the Santiago Peak Volcanics in the San Diego area contain Buchia piochii, which is diagnostic of the latest Jurassic (Tithonian); hence this fossiliferous sequence is older than the Alisitos Formation.

The type Santiago Peak Volcanics probably correlates in part with both the Eugenia Formation in Baja California, which ranges from Tithonian to probable Valanginian (Jones and others, 1976), and with the Espada Formation of Dibblee $(1950 ; 1966)$ in the Santa Ynez Mountains and southern Coast Ranges. Andesite dikes that intrude the Eugenia Formation have yielded a K-Ar age of $124.6 \pm 3.2$ million years (Minch and others, 1976, p. 146-147).

\section{CRETACEOUS SYSTEM}

\section{UPPER CRETACEOUS SERIES}

Cretaceous rocks of the Santa Ana Mountains were first reported by the California Geological Survey (Whitney, 1865), although paleontologic evidence for their age was not published for more than 20 years (Cooper, 1888; Goodyear, 1888; Bowers, 1890). Packard (in Dickerson, 1914, p. 262-263) assigned six lithologic units in the Santa Ana Mountains to the Upper Cretaceous Chico Formation, the type locality of which is in northern California. Later the uppermost of these units was found to be Paleocene in age. Packard (1916, p. 140-141) proposed the name Trabuco Formation for the lowest unit, which is nonfossiliferous. Popenoe (1937, p. 380) grouped the remaining four units into two formations, the Ladd Formation and the Williams Formation, each made up of a coarse-grained lower member and a finer grained upper member. The names were modified slightly by Popenoe (1942, p. 170-175), by Woodring and Popenoe (1945), and by Schoellhamer and others (1954), in part to distinguish them from similar names used earlier elsewhere. The resulting terms are as follows, from the top down:

Williams Formation

Pleasants Sandstone Member

Schulz Ranch Sandstone Member

Ladd Formation Holz Shale Member

Baker Canyon Conglomerate Member

Trabuco Formation

\section{TRABUCO FORMATION}

A relatively thin discontinuous sequence of red and maroon clayey conglomerate and sandstone forms the basal unit of the unmetamorphosed sedimentary strata at most places in the northwestern Santa Ana Mountains. The type section of this sequence, named the Trabuco Formation by Packard (1916, p. 140-141), is in Harding Canyon near the village of Modjeska secs. 28 and 29 , T. 5 S., R. 7 W., at the southeast corner of the map area.

The Trabuco Formation is exposed in a narrow belt along the eastern edge of the El Toro and Black Star Canyon quadrangles, from the vicinity of Williams Canyon northward to the divide between Baker Canyon and Black Star Creek. At this point it grades laterally into the lower part of the Baker Canyon Conglomerate Member of the Ladd Formation, and it cannot be rec. ognized or traced farther north. Gray (1961) assigned red conglomerate to the Trabuco Formation on the northeast slopes of the Santa Ana Mountains from near the mouth of Hagador Canyon northwestward to Mabey Canyon. These outcrops are bounded on the southwest by the Elsinore fault.

The westward extent of the Trabuco Formation beneath the cover of younger sedimentary rocks is known only from fragmentary information. About a hundred meters of the formation is present in the J. J. Stephens well, Susie M-1, in Silverado Canyon 1,400 m west of the nearest outcrop of the Trabuco ( pl. 1). The Texas Co. well, Irvine (NCT-2) No. 1, in Little Joaquin Valley $10 \mathrm{~km}$ east of Santa Ana, penetrated rocks assigned to the Bedford Canyon Formation without drilling through the Trabuco Formation. Apparently it is absent 
in the West American Oil Co. well, Irvine No. 1, $2 \mathrm{~km}$ farther west, near the Irvine Ranch headquarters, although the geologic interpretations for this well are somewhat doubtful. Other wells in the area have not been drilled deep enough to penetrate the Trabuco Formation. The outcrop pattern and the scanty subsurface results suggest that the Trabuco may be limited in areal extent to the southeastern part of the map area.

The Trabuco Formation is relatively unconsolidated, deeply weathered and easily eroded. Badland topography is developed locally. Gentle slopes are commonly covered by a moderate growth of brush, and the soil and outcrops show the brown, red, and maroon colors characteristic of the formation.

\section{STRATIGRAPHY AND LITHOLOGY}

The Trabuco Formation rests with profound angular unconformity on both the Santiago Peak Volcanics and the Bedford Canyon Formation. In the southern threequarters of the outcrop area, it is underlain by the volcanic unit; in the northern quarter, it rests directly on the Bedford Canyon Formation, the volcanic rocks apparently having been removed by erosion before depos: ition of the Trabuco.

The Trabuco Formation consists mainly of reddishbrown to maroon conglomerate, sandstone, and minor amounts of clayey siltstone. Crossbedding is present at some places in the sandstone and conglomerate. The conglomerate clasts are generally subangular to subrounded measuring as much as about $1 \mathrm{~m}$ and averaging between 7 and $15 \mathrm{~cm}$. Some clasts are so deeply weathered that they crumble when touched. Four recognizable rock types are common as clasts in the conglomerate. These include (1) coarse-grained lightcolored granitic and granodioritic types, derived from plutonic rocks of the Southern California batholith; (2) greenish-gray volcanic rocks similar to the Santiago Peak Volcanics; (3) hard gray dacite or quartz latite porphyry resembling that which intrudes the Santiago Peak Volcanics near Sierra Peak; and (4) blocks and chips of siltstone and sandstone derived from the Bedford Canyon Formation. Other rock types present in the conglomerate include quartzite, hard fine-grained volcanic rocks of many types, and chert. The conglomerate matrix is a poorly sorted clayey feldspathic sandstone containing dark-colored rock fragments and crinkly flakes of biotite bleached to various shades of greenish black to golden brown. Popenoe (1941, p. 743) studied outcrops of the Trabuco Formation and concluded that volcanic and sedimentary rocks presumably derived from the Santiago Peak Volcanics and Bedford Canyon Formation make up the major part of the conglomerate.
In addition to conglomerate, the Trabuco Formation includes conglomeratic sandstone and sandstone similar to the matrix of the conglomerate. Most sandstone beds have a reddish-brown clayey micaceous matrix that has a waxy luster on fresh surfaces. The formation is locally gray or white, and some sandstone beds contain local thin light-gray streaks. On the divide between Williams and Silverado Canyons, approximately $30 \mathrm{~m}$ of the basal part of the Trabuco Formation consists of a whitish conglomerate composed of sub. rounded to rounded cobbles and boulders with a maximum dimension of about $1 \mathrm{~m}$. The main clast types are the same as those in other exposures of Trabuco conglomerate. This whitish conglomerate apparently grades upward and laterally into the typical red strata of the Trabuco.

The thickness of the Trabuco Formation ranges from about $85 \mathrm{~m}$ just south of Silverado Creek to zero on the ridge between Ladd and Baker Canyons. It increases abruptly to a maximum of $173 \mathrm{~m}$ in Baker Canyon then decreases northward to about $115 \mathrm{~m}$ at structure section U-V ( pl. 3) and terminates in Black Star Canyon where the Trabuco intertongues with the Baker Canyon Conglomerate Member of the Ladd Formation. A measured section across the entire formation in Baker Canyon is $40 \mathrm{~m}$ thick, almost all reddish conglomerate.

Although the Trabuco Formation lacks fossils, its interfingering with the fossiliferous Baker Canyon Conglomerate Member establishes its early Late Cretaceous age. Its clayey red matrix and lack of fossils indicate nonmarine deposition.

Conglomerate similar to that of the Trabuco Formation occurs farther north and south in this part of California. In the Santa Monica Mountains northwest of Los Angeles, a red conglomerate unit is present at the base of the Upper Cretaceous section (Hoots, 1931, p. 90; Colburn and Fritsche, 1973). It has been reported to be locally $380 \mathrm{~m}$ thick (Durrell, 1954, map sheet 8). South of the Santa Ana Mountains conglomerate of the Trabuco Formation or conglomerate somewhat similar to that of the Trabuco is present in many places as far south as San Diego and beyond (Hertlein and Grant, 1939, p. 75-76); Woodford and others, 1968, p. 1469; Peterson, 1971; Nordstrom, 1970; Kennedy and Moore, 1971, p. 711).

\section{LADD FORMATION}

Popenoe (1942, p. 170) designated the type locality of the Ladd Formation as the region immediately west of the mouth of Ladd Canyon and divided the formation into the Baker Canyon and Holz Shale Members with a combined maximum thickness of approximately $520 \mathrm{~m}$. Northeast of Fresno Canyon in the northeastern 
part the map area, the formation consists of more than $900 \mathrm{~m}$ of interbedded sandstone, siltstone, and conglomerate; here the members cannot be differentiated.

\section{BAKER CANYON CONGLOMERATE MEMBER}

The Baker Canyon Conglomerate Member of the Ladd Formation crops out near the east edge of the map area in an almost continuous north-trending strip 100 to 2,000 m wide with the dip to the west. Its type locality is in Baker Canyon, north of Silverado Canyon (Popenoe, 1942). North of Sierra Peak it is present in the fault blocks on the north edge of the Santa Ana Mountains and continues, almost without interruption, along the narrow, downfaulted northeast flank of the mountains into the Elsinore trough (Gray, 1961; Gaede, 1969). In the northwestern part of the Santa Ana Mountains, it crops out in a small upfaulted block, possibly a faulted anticline, at the mouth of Blind Canyon on the north side of Santiago Creek between Irvine Park and Irvine Lake.

\section{STRATIGRAPHY AND LITHOLOGY}

The lower part of the Baker Canyon Conglomerate Member consists of a sequence of greenish-gray conglomerate beds in which many of the clasts are as much as $2 \mathrm{~m}$ in diameter. The pebbles, cobbles, and boulders are mostly well-rounded and are composed of either light-gray quartz plutonic rocks like those in the basement complex or light- and dark-gray siliceous volcanic and hypabyssal rocks. The siliceous rocks were derived largely from the Santiago Peak Volcanics and related intrusions but also include metatuff somewhat similar to that which is abundant in overlying Paleogene conglomerate. The conglomerate matrix is sandstone that is composed mainly of quartz and feldspar and contains biotite flakes and rock fragments. Sandstone beds are rather rare, occurring chiefly high in this lower part of the sequence. Thin beds of red silty sandstone are locally present near the base. North of this area between Baker and Black Star Canyons, where the Trabuco Formation pinches out, the lower part of the member is the lowest unit in the superjacent sequence. For a short stretch near Oak Flat, both the Trabuco Formation and the Baker Canyon Conglomerate Member are missing. On the crest of the mountains, north of Oak Flat, boulders in the lower part of the member are exceptionally large; the biggest observed is a slab of coarse biotite granodiorite $11 \times 10 \times 2 \mathrm{~m}$. Here the member rests directly on the basement.

The upper part of the Baker Canyon Conglomerate Member, throughout the map area, is characterized by its yellow-brown color and smaller clast size. Most of the beds are composed of conglomeratic sandstone. Some beds are finely laminated sandstone; less com. mon beds of pebble and cobble conglomerate are as much as $3 \mathrm{~m}$ thick. Sandstone beds are locally carbonate cemented and contain abundant mollusk shells.

North of Oak Flat the easily eroded upper part of the member is well exposed only in the south wall of Santa Ana Canyon. Here the upper 35 percent of the section is coarse gritty feldspathic sandstone interbedded with silty layers a few centimeters thick that contain many black carbonaceous fragments.

The contact with the overlying Holz Shale Member seems to be gradational, as thin dark-gray to black siltstone and sandy siltstone layers are interbedded with the coarser strata just below the contact.

The lower part of the Baker Canyon Conglomerate Member is possibly of nonmarine origin in the area south of Black Star Canyon. Lithologically the Baker Canyon is similar to the underlying Trabuco Formation, and the contact is gradational and in places intertonguing. In the vicinity of Black Star Canyon, the reddish Trabuco Formation is stratigraphically equivalent to at least the lower part of the greenish-gray Baker Canyon Conglomerate Member. The colors are mottled and irregular, are not confined by bedding, and are therefore not depositional features. Thick-shelled marine pelecypods such as Trigonarca, Cucullaea, Spondylus, and Pterotrigonia, which indicate a shallow marine environment, are common in the uppermost part of the conglomeratic facies and in the sandstone at the top of the member.

Popenoe (1941, p. 738-752) concluded that the Baker Canyon Conglomerate Member was entirely marine in origin and that the Trabuco Formation was a separate and distinct stratigraphic unit. However, the gradation and intertonguing of the two units indicate a more complex history involving both original depositional environments and diagenetic changes.

Conditions of deposition were somewhat different in the Oak Flat-Sierra Peak area, where the Baker Canyon Conglomerate Member is very thin and locally absent, and the basal nonmarine beds are missing. Marine fossils occur in thin lenses of gray siltstone a meter or so above the unconformable contact with the underlying Santiago Peak Volcanics. These marine strata are overlain by the coarsest greenish-gray conglomerate in the area.

The section of the Baker Canyon Conglomerate Member exposed along the Riverside Freeway shows the characteristic two-fold lithologic division. The lower part is unfossiliferous, coarse, greenish-gray, very poorly bedded conglomerate that is believed to be nonmarine. The upper part is lighter colored, better stratified, and better sorted sandstone and conglomer- 
ate presumed to be marine, although no fossils were found in it.

The Baker Canyon Conglomerate Member ranges between zero and $425 \mathrm{~m}$ in thickness. Just north of Oak Flat, $5 \mathrm{~km}$ south of the northeast corner of the map area, the member is missing, and the Holz Shale Member lies directly on the eroded surface of intrusive rocks of the Santiago Peak Volcanics. The Baker Canyon is estimated to be $425 \mathrm{~m}$ thick in its northernmost outcrop, along Santa Ana Canyon. It has a measured thickness of $245 \mathrm{~m}$ in Baker Canyon 1.5 to $3 \mathrm{~km}$ south of Oak Flat. In a cliff on the north side of the divide between Baker and Black Star Canyons, the lower part of the member is $202 \mathrm{~m}$ thick. From Baker Canyon south to Williams Canyon the member averages about $120 \mathrm{~m}$ thick, but it is thicker in Hall Canyon between Ladd and Baker Canyons, where it measures $365 \mathrm{~m}$.

Texas Co. well, Irvine (NCT-1) No.1, just north of Irvine Park, drilled through the Baker Canyon Conglomerate Member from 1,029 $\mathrm{m}$ depth to the bottom of the hole at $1,074 \mathrm{~m}$. Much farther south (along section R-S, pl. 3), West American Oil Co. well, Irvine No. 1, near Irvine Ranch headquarters, and Texas Co. well, Irvine (NCT-2) No.1, in Little Joaquin Valley, drilled to basement without penetrating the member. Still farther south, however, beyond the south margin of the map, the conglomerate reappears, in Shell Oil Co. well, Irvine Corehole No. 5, between $929 \mathrm{~m}$ depth and the bottom of the hole, and continues southward in Shell Oil Co. well, Irvine Corehole No. 7, and in Morton and Sons wells, El Toro No.14-1 and Irvine No. 174-1 (Schoellhamer and Vedder, 1975). The absence of this unit from the subsurface section beneath the southcentral part of the map area may indicate its gradation there into the Holz Shale Member in the northwesttrending central strip of the incipient Los Angeles basin which later ceased to subside and became part of the Anaheim nose (see section on "Subsurface Structures South of El Modeno Fault").

\section{PETROGRAPHY}

Thin sections from sandstone beds in the Baker Canyon Conglomerate Member show variations in the proportions of the prevailing constituents: quartz, plagioclase, biotite, volcanic rock, and rather rare orthoclase. The most siliceous sample is composed of grains $0.6 \mathrm{~mm}$ across (table 3 ). The least siliceous sample, from the nonmarine lower part of the unit on the Riverside Freeway, is composed of grains up to 1.7 $\mathrm{mm}$ in diameter (table 3). Other samples from the nonmarine beds are similar. A single thin section form the marine upper part of the unit represents the sandstone along the Riverside Freeway. This marine
TABLE 3.-Petrography of the Ladd Formation

\begin{tabular}{|c|c|c|}
\hline Rock type & Composition & Comments \\
\hline \multicolumn{3}{|c|}{ Baker Canyon Conglomerate Member } \\
\hline $\begin{array}{l}\text { Nonmarine } \\
\text { sand- } \\
\text { stone. } \\
\text { lower } \\
\text { part of } \\
\text { member. }\end{array}$ & $\begin{array}{l}\text { Quartz } \\
\text { Andesine } \\
\text { Biotite and chlorite } \\
\text { Orthoclase _...... } \\
\text { Rock fragments } \\
\text { Matrix }\end{array}$ & $\begin{array}{l}\text { Of Bedford Canyon Formation or similar } \\
\text { metasedimentary unit. } \\
\text { Composed of clay, mica shreds, and rock } \\
\text { powder. }\end{array}$ \\
\hline $\begin{array}{l}\text { Nonmarine } \\
\text { sand- } \\
\text { stone, } \\
\text { lower } \\
\text { part of } \\
\text { member. }\end{array}$ & 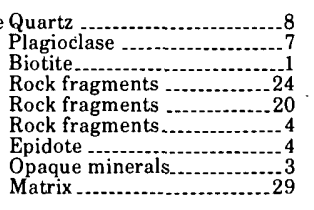 & $\begin{array}{l}\text { Of Bedford Canyon (?) Formation } \\
\text { Of Santiago Peak (?) Volcanics } \\
\text { Of plutonic rock. }\end{array}$ \\
\hline $\begin{array}{l}\text { Marine } \\
\text { sand- } \\
\text { stone, } \\
\text { upper } \\
\text { part of } \\
\text { member. }\end{array}$ & 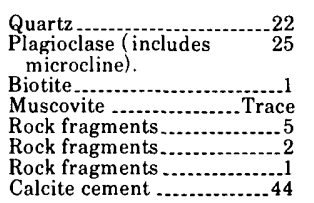 & $\begin{array}{l}\text { Of Bedford Canyon (?) Formation. } \\
\text { Plutonic rock. } \\
\text { Schist. }\end{array}$ \\
\hline
\end{tabular}

Holz Shale Member

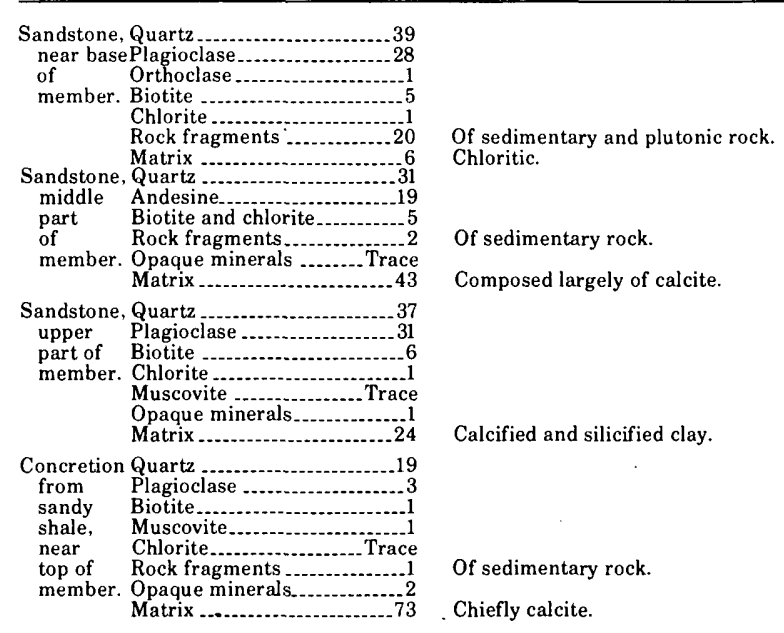

sandstone sample is made up of grains up to $3 \mathrm{~mm}$ in diameter (table 3).

Pebbles, cobbles, and boulders from one locality in the lower part of the Baker Canyon Conglomerate Member were studied petrographically. The sample was taken about $100 \mathrm{~m}$ stratigraphically above the base of the member in Santa Ana River gorge, at the south edge of the Riverside Freeway. Here the largest boulders, rounded and up to $2 \mathrm{~m}$ in diameter, are all pale biotite granite, but by far the commonest clasts are dark-green tuff, breccia and porphyry of "Baker Canyon type" (Woodford and others, 1968, p. 1471). The porphyry is similar to that which intrudes the Santiago Peak Volcanics near Sierra Peak. A sample of 100 clasts up to $30 \mathrm{~cm}$ in diameter, was examined by a combination of thin sections (20 representative samples), immersion oil study of mineral grains, and hand 
lens. They are identified below; note the absence of quartzite pebbles and cobbles:



\section{AGE AND CORRELATION}

The late Turonian age of the Baker Canyon faunas is best defined by the presence of Subprionocyclus, an ammonite genus of cosmopolitan range. Other fossils are included in the megafossil lists in this report and in Packard (1916) and Popenoe (1937, 1941).

Popenoe (1942, p. 178) assigned the molluscan fauna of the Baker Canyon Conglomerate Member to the Glycymeris pacificus fauna of Turonian age. Two rather indistinct faunal facies occur in the Glycymeris pacificus fauna. The lower, the Trigonarca californica facies, is characterized by a flood of thick-shelled bivalved mollusks. T. californica Packard and Acteonella oviformis Gabb are the most abundant species. The higher, the Cucullaea gravida facies, has a greater proportion of thin-shelled pelecypods and gastropods and is found mostly in finer grained sandstone.

\section{HOLZ SHALE MEMBER}

The areal distribution of the Holz Shale Member of the Ladd Formation is essentially the same as that of the underlying Baker Canyon Conglomerate Member. Its type locality is at Holz Ranch on the north side of Silverado Canyon just west of the mouth of Ladd Canyon (Popenoe, 1942 , p. 171). Its main outcrop belt extends northward along the eastern edge of the map area from Modjeska to the mouth of Coal Canyon just south of the Santa Ana River, and thence eastward as far as Fresno Canyon. The Holz Shale and Baker Canyon Conglomerate Members have not been separated on the geologic map southeast of Fresno Canyon and are shown as the Ladd Formation, undifferentiated. Other outcrops are in faulted anticlines north and northeast of Irvine Lake. Subsurface data indicate that the Holz is present southeast of Tustin, and Shoellhamer and Vedder (1975) have recognized the member in wells drilled in the San Joaquin Hills to the south.

The Holz Shale Member characteristically erodes to form smooth rounded slopes that are covered with sparse brush and thick grass where sufficient soil has developed.

The contact between the Baker Canyon Conglomerate and Holz Shale Members everywhere seems to be gradational in a succession of sandstone and gray shale beds. In mapping, the contact was drawn arbitrarily at the top of the highest conspicuous sandstone bed. and this lithologic distinction is undoubtedly timetransgressive.

\section{STRATIGRAPHY AND LITHOLOGY}

The Holz Shale Member is made up chiefly of thin to thick beds of siltstone, sandy siltstone, and shale. It contains concretions ranging from $5 \mathrm{~cm}$ to $1 \mathrm{~m}$ in thickness that are flattened parallel to the bedding and that vary from nearly pure calcite to limy shale. Calcareous and arenaceous foraminifers are present throughout, and megafossils are locally abundant.

A section of the Holz Shale Member measured on the south side of Silverado Canyon is $350 \mathrm{~m}$ thick, and the member may be $460 \mathrm{~m}$ thick a little farther north. In Black Star Canyon a measured section is at least $230 \mathrm{~m}$ thick. In the complexly faulted area north of the Whittier fault, the member is at least $300 \mathrm{~m}$ thick. West of the outcrop area, the Holz was found to be $460 \mathrm{~m}$ thick in Texas Co. well, Irvine (NCT-1) No. 1, northeast of Irvine Park, $730 \mathrm{~m}$ thick in Texas Co. well, Irvine (NCT-2) No. 1, in Little Joaquin Valley due east of Santa Ana and Tustin, and $565 \mathrm{~m}$ thick in Shell Oil Co. well Irvine Core Hole No. 5, at the south edge of the map area.

Between Williams and Black Star Canyons the member includes cliff-forming lenses that are chiefly sandstone and conglomerate, as much as $60 \mathrm{~m}$ thick, and unfossiliferous. They are composed of alternating sequences of conglomerate, sandstone, siltstone, and pebbly mudstone (fig. 9). The conglomerate clasts, up to $1 \mathrm{~m}$ in diameter, are largely quartz latite or dacite porphyry similar to those in the Baker Canyon Conglomerate Member. The sandstone and siltstone con- 
tain numerous black carbonaceous chips and particles. Many beds within the lenses are graded, and some sandstone beds are cross laminated, suggesting deposition by turbid flows. They are the only such flow deposits found in the Cretaceous sequence in the northern Santa Ana Mountains.

\section{PETROGRAPHY}

Four thin sections give indications of the nature of the coarser grains in the Holz Shale Member (table 3). Three are from sandstone beds in shale. One sandstone specimen is from a nearly basal bed in Shell Oil Co. well, Irvine Core Hole No. 5, close to the south edge of the map area. A section from a second bed is somewhat higher in the Holz at the east edge of Irvine Block 113 near Fremont Canyon (table 3). A section from a third bed is in the upper part of the Holz Shale Member southeast of Fremont Canyon (table 3). A section from a concretion in sandy shale is near the top of the Holz southeast of Fremont Canyon. Collectively these samples show that quartz commonly exceeds 35 percent, and feldspar (almost entirely plagioclase) 25 percent. Rock fragments are variable but may constitute as much as 20 percent of the rock.

\section{AGE AND CORRELATION}

Molluscan faunas indicate a Late Cretaceous age for the Holz Shale Member. The basal $100 \mathrm{~m}$ of the Holz yields a sparse molluscan fauna assigned to the Turonian Stage. This fauna is similar to the uppermost fauna in the Baker Canyon Conglomerate Member. The remainder of the Holz was assigned by Popenoe (1942) to his Turritella chicoensis and Turritella chicoensis perrini divisions, the lower and middle faunal divisions, respectively, of the Glycymeris veatchii fauna (Campan. ian Stage).

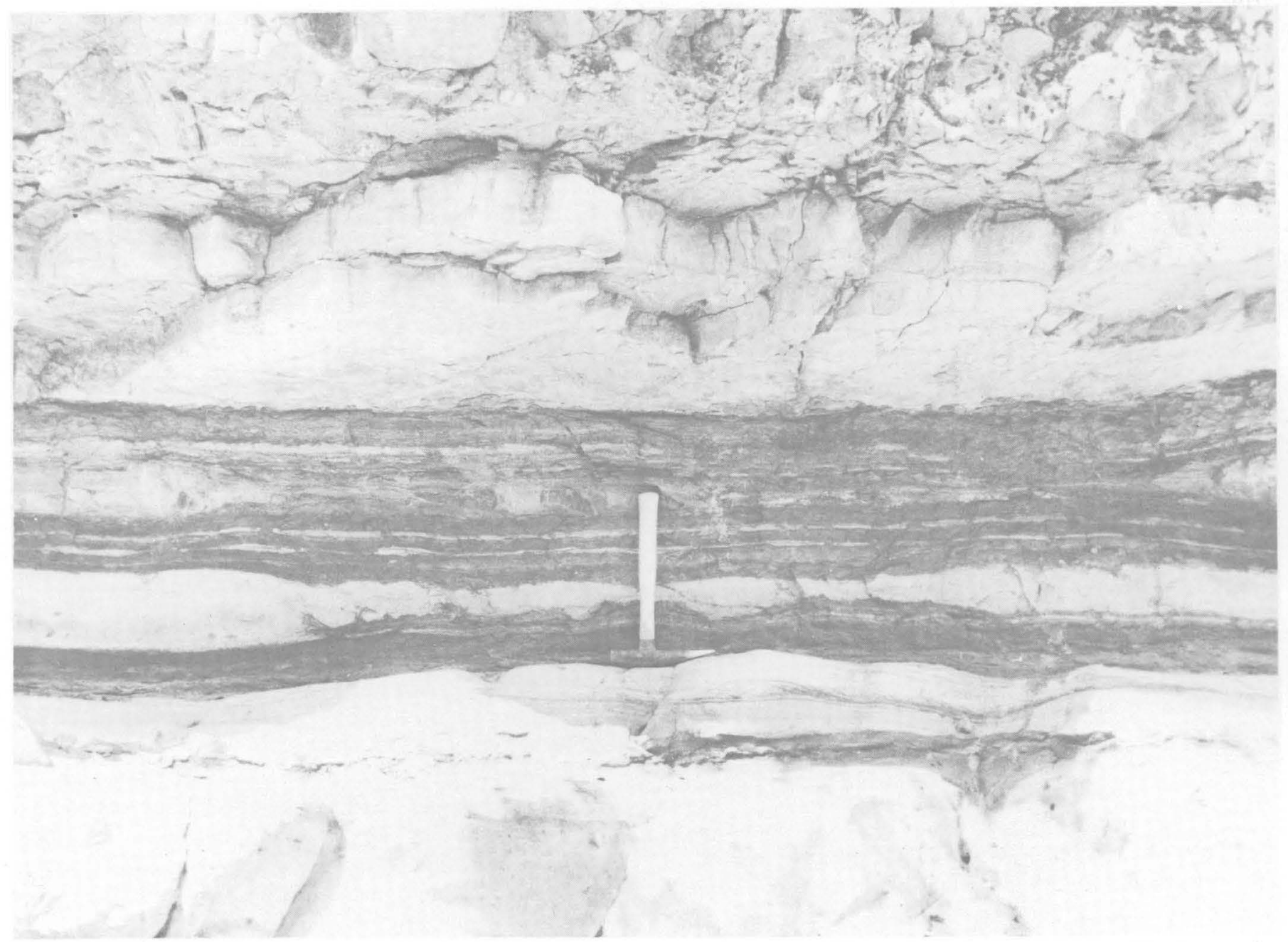

FIGURE 9.- Sedimentary features of graded lens in the Holz Shale Member of the Ladd Formation, showing unsorted conglomerate, graded bedding in sandstone, and truncated cross lamination, in a section $150 \mathrm{~m}$ upstream from where Black Star Canyon Road leaves stream bottom. 
Crassatella cf. C. tuscana, Etea angulata, Parallelodon cf. $P$. vancouverensis, Eriphyla lepidus, and Turritella chicoensis chicoensis are restricted to the $T$. chicoensis division.

Assemblages of the Turritella chicoensis perrini division occur in calcareous and sandy beds near the top of the Holz Shale Member and are most abundant a little north of Williams Canyon. The fossils in these beds are remarkable for their large size, robust shells, and numbers of species that are rare or absent elsewhere. Only a few species are restricted to this division, the most abundant being $T$. chicoensis and Crassatella cf. C. lomana (long form).

Merle Israelsky in consultation with Boris Laiming (written commun., 1952) assigned foraminiferal assemblages in samples from outcrops of Holz Shale Member on the north side of the mountains to Goudkoff's (1945) G-1 zone. These samples came from the northwestern and northeastern parts of sec. 36, T. $3 \mathrm{~S}$., R. 8 W., near Santa Ana Canyon and the center of sec. 7, T. 4 S., R. 7 W., about $2 \mathrm{~km}$ northwest of Oak Flat. A. A. Almgren (in Colburn and Fritsche, 1973, p. 40 and fig. 3) notes that the middle part of the member in Silverado Canyon contains foraminifers that suggest Goudkoff's G-1 zone, which Almgren tentatively correlates with the upper part of the Coniacian, Santonian, and lowermost Campanian Stages. Popenoe and others (1960) correlate the G.1 zone with the Coniacian and lower part of the Santonian Stages. H. R. Lang (1978) assigns a range of Turonian to Campanian to the Silverado Canyon Section.

\section{WILLIAMS FORMATION}

The Williams Formation was named and described by Popenoe (1937, p. 380 ; 1942, p. 173) for exposures along Williams Canyon near its mouth. He divided the formation into the Schulz Member and Pleasants Sandstone Member. The Schulz Member was renamed the Schulz Ranch Sandstone Member by Woodring and Popenoe (1945).

\section{SCHULZ RANCH SANDSTONE MEMBER}

The type locality of the Schulz Ranch Sandstone Member is approximately $0.4 \mathrm{~km}$ upstream from the mouth of Williams Canyon near the west boundary of Schulz Ranch (Popenoe, 1942, p. 173-174). From the southeast corner of the map area near Modjeska to Black Star Canyon, the Schulz Ranch Sandstone Member crops out in a narrow belt. Between Black Star and Fremont Canyons, exposures of the member are more extensive due to faulting and consequent repetition of section. North of Fremont Canyon the outcrop narrows and trends northward along Coal Canyon until it disappears beneath the alluvium of the Santa Ana
River. The member is also present at the surface in isolated fault blocks north and south of Santiago Creek between Irvine Park and Irvine Lake.

The Schulz Ranch Sandstone Member is a prominent cliff-forming unit throughout the area, and its bold outcrops of yellowish-white to light-brown sandstone contrast sharply with the darker gray, smooth, gentle slopes of the underlying Holz Shale Member of the Ladd Formation (fig. 10).

\section{STRATIGRAPHY AND LITHOLOGY}

The Schulz Ranch Sandstone Member of the Williams Formation unconformably overlies the Holz Shale Member of the Ladd Formation and nowhere in the map area overlaps older rock units. Its basal thickbedded pebbly sandstone and conglomerate contrast sharply with the underlying shale, although at places angular clasts of gray siltstone of the Holz and blocks of conglomerate, some as much as $10 \mathrm{~m}$ on a side containing fossils characteristic of the Baker Canyon Member of the Ladd Formation, are distributed erratically in this part of the Schulz Ranch Sandstone. These clasts and blocks suggest a local unconformity at the base. Presumably these transported bocks were emplaced by submarine landslides.

The Schulz Ranch Sandstone Member is typically coarse-grained cream-white to yellowish-brown very poorly sorted feldspathic sandstone, composed mainly of angular to subrounded grains of quartz and feldspar and various amounts of greenish-black to black crinkly biotite flakes in a sparse clayey matrix. It also contains numerous isolated pebbles and cobbles, and some well-rounded pebbles, cobbles, and boulders, as much as $30 \mathrm{~cm}$ in diameter and averaging 5 to $10 \mathrm{~cm}$, are concentrated in beds a meter or so thick. Most beds in this member are massive, but some are crossbedded. Between Black Star and Fremont Canyons, conglomeratic sandstone is interbedded with siltstone beds 3 to $9 \mathrm{~m}$ thick. The sandstone here contains cannonball concretions several centimeters to 1 meter in diameter, cemented by calcite. Concretions, elongate parallel to the bedding, are also present.

\section{PETROGRAPHY}

Six samples from the Schulz Ranch Sandstone Member were point-counted in thin section (table 4). Three are relatively fine-grained and well-cemented sandstone rich in plagioclase. One of these samples is from near the base of the member southeast of Fremont Canyon. The second is medium grained and from the lower part of the member, south of Modjeska in the southeastern part of the map area. The third is fine to medium grained and from the middle part of the member, north of Fremont Canyon. The two northern 
samples are unusually rich in biotite, and the southern one lacks mica.

The other three samples are typical of the Schulz Ranch Sandstone Member. They are very coarse grained sandstone and are poorly cemented and poorly sorted, with rare small pebbles, and have exceptionally abundant alkali feldspar. One of these samples is from the ridge northwest of Black Star Canyon, one from the east edge of Irvine Park, and one from elevation $535 \mathrm{~m}$ $(1,750 \mathrm{ft}), 3 \mathrm{~km}$ east of Santiago Dam.

\section{SUBSURFACE DISTRIBUTION}

The Schulz Ranch Sandstone Member thickens toward the northwest. Sections $T \cdot X$ and $U \cdot W$ (pl. 3), south of Silverado Canyon and east of Santiago Creek, show thicknesses near $85 \mathrm{~m}$. A measured section along the fire road east of Baker Canyon, in the $\mathrm{NE}^{1 / 4} \mathrm{sec}$. 7, T. 5 S., R. 7 W., totals $75 \mathrm{~m}$ im thickness. Section $H-O$ (pl. 3) indicates a thickness of about $200 \mathrm{~m}$ between
Fremont and Black Star Canyons. Elsewhere in this area, and as drilled farther west in Texas Co. well, Irvine (NCT-1) No. 1, just north of Irvine Park, the maximum thickness of about $280 \mathrm{~m}$ occurs.

AGE AND CORRELATION

The Schulz Ranch Sandstone Member is sparsely fossiliferous throughout the area. Four or six fossil localities are in carbonate-cemented sandstone of conglomerate near the base of the member, all west and north of Baker Canyon. Locality F-37 on the west wall of Black Star Canyon near Hidden Ranch is in blocks of Baker Canyon Conglomerate redeposited in the basal Schulz Ranch Sandstone. The others are in siltstone northwest of Fremont Canyon and near the top of the member northeast of Irvine Lake. W. P. Popenoe (oral commun., 1977) would place some of these beds in the Holz Shale Member of the Ladd Formation. Localities

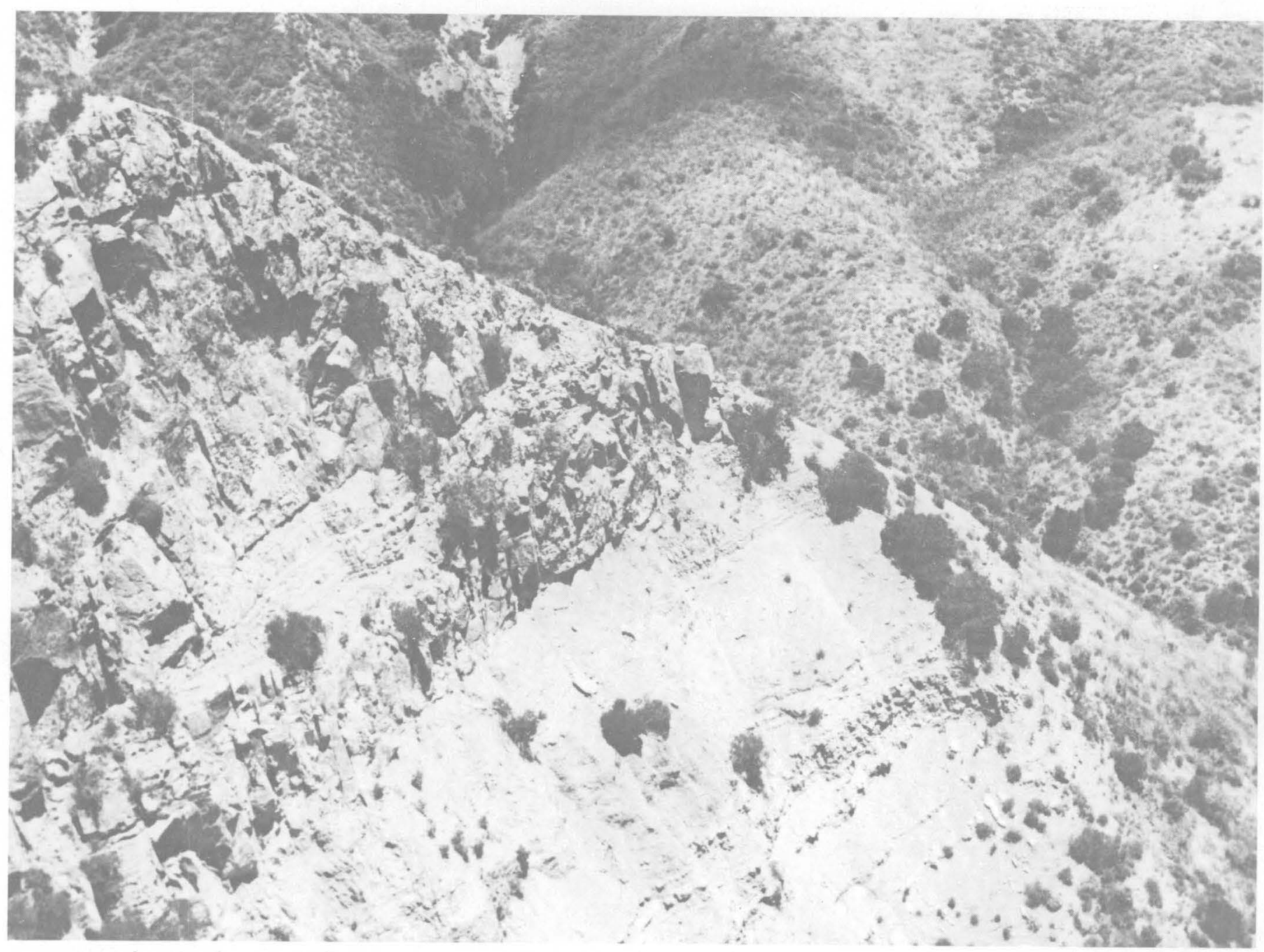

Figure 10.- Contact (at center) between the Holz Shale Member of the Ladd Formation and the overlying Schulz Ranch Sandstone Member of the Williams Formation taken from road connecting Main Divide Motorway with road in Fremont Canyon, Irvine Block 34 . Basal part of the Schulz Ranch Sandstone Member shown here is about $50 \mathrm{~m}$ (150 ft) thick. View northeast. 
TABLE 4.-Petrography of the Williams Formation

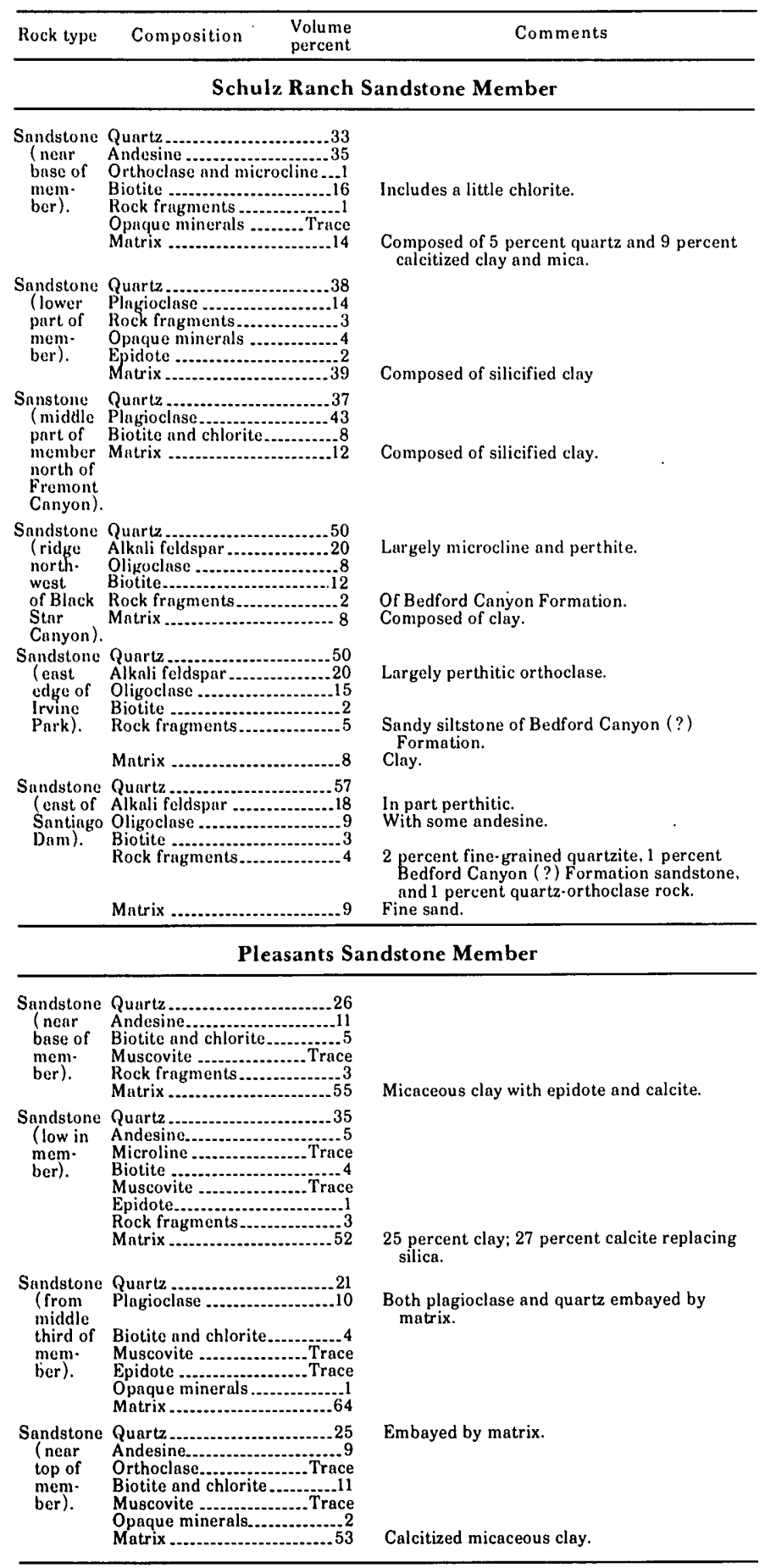

near the head of Black Star Canyon yield pelecypods of the genera Trajanella, Opis, and Coralliochama. Coralliochama, a rudistid, indicates a shallow marine environment. Elsewhere, the presence of Turritella chicoensis indicates the Glycymeris veatchii fauna of the Campanian Stage.

\section{PLEASANTS SANDSTONE MEMBER}

The type locality of the Pleasants Sandstone Member is at Pleasants Ranch at the mouth of Williams Canyon (Popenoe, 1942, p. 175). The distribution of the member is irregular because of faulting and the profound unconformity at the base of the overlying Silverado Formation of Paleocene age. The Pleasants Sandstone Member extends from the southeast corner of the map area northward almost to Silverado Canyon, north of which it has been overlapped by younger strata for about $1,200 \mathrm{~m}$ along the strike. It reappears on the ridge southeast of Baker Canyon and is well exposed in fault blocks as far northwest as the Fremont Canyon drainage. Isolated fault blocks of Pleasants Sandstone Member are present north and south of Irvine Park and between Blind and Fremont Canyons. The northeastermost exposure of the member is in Irvine Block 35, on the ridge between Fremont Canyon and the Gypsum Canyon drainage. Farther north and east, it is overlapped by the Silverado Formation.

The contact between the Pleasants Sandstone Member and the underlying Schulz Ranch Sandstone Member appears to be gradational (fig. 11). The boundary is rarely well exposed, for the Pleasants is easily weathered and creeps down over the cliffy Schulz Ranch Sandstone Member beneath. The contact is marked by a change in slope as well as a change from the creamy-white pebbly sandstone of the Schulz Ranch to the brown and gray fine-grained sandstone of the Pleasants and usually can be located within a meter or so.

\section{STRATIGRAPHY AND I.ITHOLOGY}

The Pleasants Sandstone Member is 0 to $395 \mathrm{~m}$ thick; the maximum thickness occurs north of Irvine Park, including that penetrated in the Texas Co. well, Irvine (NCT-1) No. 1. A complete section of the Pleasants Sandstone Member, about $150 \mathrm{~m}$ thick, is well exposed along the Santiago Truck Trail at the extreme southeast corner of the map area. Here the uppermost part of the Schulz Ranch Sandstone Member is typical poorly bedded cream-white feldspathic sandstone, in contrast to the 1 meter of pinkish-brown, somewhat better bedded, poorly sorted feldspathic sandstone and sandy siltstone containing black carbonaceous fragments, at the base of the Pleasants. The next higher 1 meter of section consists of rather well bedded micaceous sandstone grading upward into typical structureless soft gray and brown sandstone. A few $0.3-\mathrm{m}$-thick beds of gritty sandstone contain pebbles as much as 5 $\mathrm{cm}$ in diameter. A prominent $6 \cdot \mathrm{m}$-thick bed $15 \mathrm{~m}$ above the base is composed of coarser feldspathic sandstone with crinkly biotite flakes and some muscovite. The next higher $120 \mathrm{~m}$ or more of the Pleasants is made up of two interbedded types of sandstone; the more abundant one is massive and characterized by biotite and black carbonaceous fragments, the less abundant one is harder, thin bedded, less silty and 
characterized by biotite and some muscovite. Both types of sandstone contain richly fossiliferous ellipsoidal concretions. At many places, a few thin pebble layers grade sequentially upward into pebbly sandstone and medium-grained sandstone. In all areas the Pleasants includes thin discontinuous conglomerate lenses. Northeast of Irvine Lake the upper beds include a zone of calcareous sandstone and, north of Irvine Park, a 9-m-thick coarse massive concretionary sandstone lens that displays cavernous weathering. In general, the upper part of the member is coarser grained than the lower part.

\section{PETROGRAPHY}

Thin sections from the Pleasants Sandstone Member show that it contains less feldspar than older Upper Cretaceous sandstones and that it more commonly con- tains muscovite (table 4). One thin section from near the base of the member on the Santiago Truck Trail, south of Santiago Creek in the southeast corner of the map area, has grains up to $1.3 \mathrm{~mm}$ diameter, averaging $0.07 \mathrm{~mm}$. Another thin section from low in the member near Santiago Creek $3 \mathrm{~km}$ farther north has grains up to $0.55 \mathrm{~mm}$, averaging $0.06 \mathrm{~mm}$; one from sandstone in the middle third of the sequence on the Santiago Truck Trail has grains up to 0.47 , averaging $0.05 \mathrm{~mm}$, and one from a fossiliferous sandstone near the top of the member just southeast of Black Star Canyon has grains up to $0.29 \mathrm{~mm}$, averaging $0.04 \mathrm{~mm}$.

AGE AND CORRELATION

Mollusk assemblages in the Pleasants Sandstone

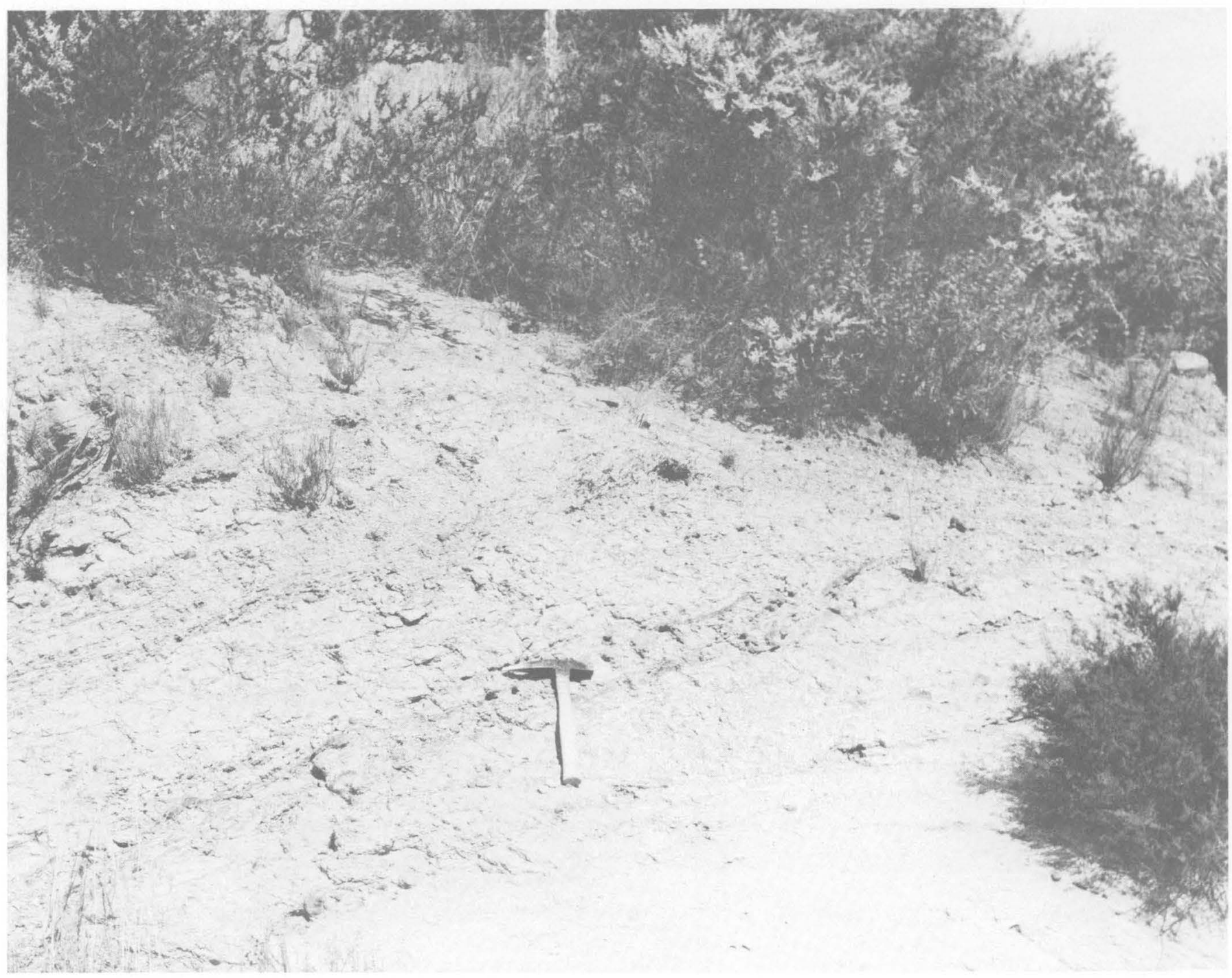

FIGURE 11.- Contact (directly below hammer handle) between the Schulz Ranch Sandstone (on right) and Pleasants Sandstone Members (on left) of the Williams Formation; contact is gradational through about 1 meter. Just east of Hill 1925 on Santiago Truck Trail. View north. 
Member are assigned by Popenoe (1942) to the highest faunal division of the Glycymeris veatchii fauna, the Metaplacenticeras pacificum division, the youngest faunal division of the Cretaceous in the Santa Ana Mountains. Species of mollusks are numerous, but few of those that occur abundantly are restricted to the division. Lembulus cf. L. striatula, Atira ornatissimus, Legumen ooides, and an undescribed species of Meekia generally occur no lower in the Santa Ana Mountains, and Calva bowersiana is almost entirely restricted to this division. The ammonite Metaplacenticeras pacificum is a common and characteristic fossil that occurs at almost every fossil locality in the member. Matsumoto (1959-60, v. 2, p. 66), basing his conclusions upon the known stratigraphic range of the genus, refers the beds containing it to the upper part of the Campanian Stage.

Fossils from localities in the Pleasants Sandstone Member are cited in this report in the "List of Megafos: sils" section.

\section{TERTIARY SYSTEM}

\section{PALEOCENE SERIES}

\section{SILVERADO FORMATION}

Sedimentary rocks of Paleocene age were first recognized and described in the northwestern Santa Ana Mountains by Dickerson (1914), who assigned them, primarily because of faunal similarity, to the Martinez Formation of central California. English (1926) followed the usage established by Dickerson. Woodring and Popenoe (1945) measured stratigraphic sections and identified fossils from the Paleocene strata in several parts of the northwestern Santa Ana Mountains. They named the Silverado Formation and defined its type region as the area about $1 \mathrm{~km}$ northeast of Irvine Park. Their measured composite section northeast of Irvine Park, block 19, between two tributaries to Santiago Creek showed about $350 \mathrm{~m}$ of strata exposed above the Pleasants Sandstone Member of the.Williams Formation and below the Santiago Formation.

The lower part of the Silverado Formation contains two relatively thin, distinctive, and widespread clay beds that serve as useful stratigraphic markers throughout most of the map area (pl. 1). The lower marker, defined by Woodring and Popenoe (1945), is called the Claymont Clay Bed, a name derived from a clay mine on the west side of Coal Canyon in Irvine Ranch Block 33, $2 \mathrm{~km}$ south of the Santa Ana River. The type locality for the Claymont Clay Bed is near the divide between Gypsum and Fremont Canyons (Gypsum Creek and Sierra Canyon on Woodring and Popenoe's map) and includes the excellent exposures in the southern part of Irvine Ranch Block 34. The upper marker is the Serrano Clay Bed, named for the Serrano Clay pits about $1 \mathrm{~km}$ southeast of the divide between Santiago and Aliso Creeks in the southeast corner of the map (sec. 32, T. 5 S., R. 7 W.; Sutherland, 1935, p. 81; Woodring and Popenoe, 1945).

Outcrops of the Silverado Formation are present in fault blocks extending from the northeast corner of the map area to Irvine Park; from there a nearly continuous belt of outcrops extends along the northeast side of Santiago Creek to the southeast corner of the map area. The formation also is exposed over small areas on the southwest slope of the foothills in the vicinity of Rattlesnake and Bee Canyons. Data on the subsurface distribution of the Silverado Formation are incomplete. Wells drilled near outcrops yield few additional data, and wells in the northwest part of the map have not been drilled deep enough to penetrate the Silverado. The presence of the Silverado Formation in the Texas Co. well, A 13-1, located about $3 \mathrm{~km}$ west of Anaheim (Woodring and Popenoe, 1945; Schoellhamer and Woodford, 1951, suggests that the formation may extend over much of the eastern Los Angeles basin (Yerkes and others, 1965, fig.7). Southeast of Tustin, however, several wells, including the Amerada $\mathrm{Pe}$ troleum Corp. well, Irvine No. 63-1, and the Shell Oil Co, wells, Irvine Coreholes Nos. 4, 5, 2, and 12, reached rocks of Late Cretaceous age without passing through the Silverado Formation. It may have been removed locally by erosion in middle Tertiary time, as the Silverado crops out in the San Joaquin Hills to the south (Vedder and others, 1957; Yerkes and others, 1965, fig.7).

The contact between the Silverado Formation and the underlying rocks is everywhere and unconformity representing an episode of deformation and extensive erosion and deep weathering between the deposition of marine Upper Cretaceous rocks and Paleocene rocks. An angular discordance has not been observed, but the Silverado rests on progressively older rocks from southwest to northeast. Near Irvine Park the formation rests on the Pleasants Sandstone Member of the Williams Formation. Northeastward in the Fremont Canyon drainage, the Silverado Formation transgresses the eroded edges of the Schulz Ranch Sandstone Member of the Williams Formation and the Holz Shale Member of the Ladd Formation. There, at least $370 \mathrm{~m}$ of Upper Cretaceous strata was removed before deposition of the Paleocene. A few kilometers east of the map area, east of the Elsinore fault, the Silverado rests directly on the Bedford Canyon Formation and granitic rocks of the Southern California batholith.

Where the uppermost part of the Silverado Formation contains marine fossils, it consists of fine- to medium-grained sandstone, and the contact with the overlying basal conglomerate of the Santiago Formation is sharp. Where both formations are nonfossiliferous, the contact is commonly difficult to discern, as it lies between similar rocks, without apparent discordance. North of Irvine Lake and west of the site of the 
Santiago Coal Mine, however, its uppermost bed contains a brackish-water fauna (Woodring and Popenoe, 1945).

The mineral and rock fragments that make up the clastic sedimentary rocks of the Silverado Formation are traceable to crystalline and semicrystalline bedrock sources to the east.

Davis (1978) determined current directions at 85 places in the Silverado Formation, probably all in nonmarine parts. All of his conclusions were based on dip-corrected measurements or crossbedding. At 52 data points in three localities near Irvine Lake the corrected dips were northwest of north, away from the region of exclusively continental deposition. One of these localities was below the Claymont Clay Bed, $3 \mathrm{~km}$ north of the lake; the other two were just above the clay, one north of Irvine Park, the other just north of the mouth of Black Star Canyon. North of the mouth of Silverado Canyon, $8 \mathrm{~km}$ to the south, the crossbeds originally dipped west or southwest. Farther south, near Modjeska, corrected crossbed dips were variable, but all eastward.

\section{STRATIGRAPHY AND LITHOLOGY}

The Silverado Formation is characteristically composed of four units, in ascending order: unit A, basal conglomerate; unit $B$, a rather thin sequence of sandstone and siltstone: unit $\mathrm{C}$, the Claymont Clay Bed; and unit D, an uppermost, thick sequence of sandstone, siltstone, and conglomerate, which includes the Serrano Clay Bed. Units A, B, and C are nonmarine; unit $D$ is in part marine in the type region of the Silverado and farther northeast. The formation probably is wholly nonmarine in the southeastern part of the map area, beyond Black Star Canyon. There the Serrano Clay Bed occurs $75 \mathrm{~m}$ above the Claymont Clay Bed. In its type region northeast of Irvine Park, the Silverado Formation is about $370 \mathrm{~m}$ thick. It reaches its maximum thickness of about $450 \mathrm{~m}$ just to the east, $1 / 2 \mathrm{~km}$ west of the old Santiago Coal Mine (Woodring and Popenoe, 1945); thence its thickness decreases eastward to about $240 \mathrm{~m}$ southeast of Baker Canyon. In the north, on the ridge between Coal and Gypsum Canyons, the formation is about $200 \mathrm{~m}$ thick; about $370 \mathrm{~m}$ was penetrated just beyond the northeastern corner of the map area, in Godfrey Drilling Co., Botiller prospect well No. 1.

\section{UNIT A, BASAL CONGLOMERATE}

Unit $\mathrm{A}$ is up to $35 \mathrm{~m}$ thick, most commonly between 2 and $12 \mathrm{~m}$. At the north in the Coal, Gypsum, and Fremont Canyons area (pl. 4), it is 2 to $6 \mathrm{~m}$ thick. Just north of lower Santiago Creek, from Irvine Park east to the old Santiago Coal Mine, it is as much as $8 \mathrm{~m}$ thick, but locally it is merely a thin layer of coarse gritty sandstone. Farther southeast the thickness varies erratically and on the divide between Santiago and Aliso Creeks reaches the maximum of $40 \mathrm{~m}$.

The basal conglomerate is unbedded, unfossiliferous, grayish to yellowish brown or red, and almost certainly nonmarine. It is composed of pebbles, cobbles, and rare boulders as much as $45 \mathrm{~cm}$ in diameter, mostly subrounded, in a clayey arkosic sandstone matrix. About one-third of the pebbles and larger clasts are dark-gray, mildly metamorphosed sedimentary rocks, largely metasandstone and metasiltstone probably derived from the Bedford Canyon Formation. About onefourth are quartzite. Perhaps 3 percent are granite gneiss. The other clasts are mostly thoroughly weathered biotite-rich quartz plutonite, pale siliceous volcanic rocks, vein quartz, feldspathic sandstone, siltstone, and limy sandstone similar to the concretions of the Pleasants Sandstone Member of Late Cretaceous age.

\section{UNIT B, SANDSTONE AND SILTSTONE}

Unit B overlies the basal conglomerate and is as much as $55 \mathrm{~m}$ thick. It is best exposed in Irvine Block 34, on the divide between Fremont and Gypsum Canyons ( $\mathrm{pl}$. 4) and is made up of interbedded layers of sandstone and siltstone. Most of the sandstone beds are composed of quartz and clay (up to 60 percent), more or less altered feldspar, and partly altered biotite. The uppermost bed, just below the Claymont Clay Bed, is in most places a golden-yellow or dirty-white sandstone made up of quartż without feldspar and a clay mineral. At places the clay mineral occurs as large flakes, an alteration product of biotite. Rare jet-black pebbles are schorl with 60 to 80 percent quartz and probably were derived from the identical distinctive tourmalinite so abundant in the quartz plutonite bedrock outside the map area at the abandoned Cajalco tin mine west of Lake Mathews, $8 \mathrm{~km}$ northeast of the Santa Ana Mountains. In a few places the bed just below the Claymont Clay Bed is either a micaceous siltstone or a finegrained quartz-pebble conglomerate. Some of the lower sandstone layers are crossbedded. Farther south, in the north corner of Irvine Block 71, $2.6 \mathrm{~km}$ northeast of the Santiago Creek dam, $1 \mathrm{~m}$ of dark carbonaceous to lignitic shale is present in a gritty sandstone sequence near the top of the unit. In the southeastern part of the map, a well-exposed section across unit B is $32 \mathrm{~m}$ thick.

Thin sections of sandstone from the main part of unit $\mathrm{B}$ and from the uppermost bed, $2 \mathrm{~m}$ below the Claymont Clay Bed, on the divide between Coal and Frem. ont Canyons, were examined (table 5). 


\section{UNIT C, THE CLAYMONT CLAY BED}

The Claymont Clay Bed seems to lie conformably on sandstone of unit B ( pl. 4). It is only a meter or so thick in the Santa Ana Mountains, but it weathers to a

TABLE 5. - Petrography of the Silverado Formation: units $B$ and $C$

\begin{tabular}{|c|c|c|}
\hline Rock type & $\begin{array}{l}\text { Volume } \\
\text { percent }\end{array}$ & Comments \\
\hline $\begin{array}{l}\text { Sandstone. } \\
\text { unit B } \\
\text { (basal } \\
\text { part. } \\
\text { Snntingo } \\
\text { Creek. } \\
\text { near. } \\
\text { Mod- } \\
\text { jeska). }\end{array}$ & 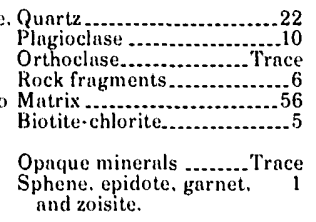 & $\begin{array}{l}\text { Sedimentary, plutonic, and volcanic rocks. } \\
\text { Calcite replaces original matrix. } \\
\text { Crushed and spread biotite is bleached; fresh } \\
\text { biotite in undeformed books. }\end{array}$ \\
\hline $\begin{array}{l}\text { Sandstone. } \\
\text { unit B } \\
\text { (core } \\
\text { sumple } \\
\text { from } \\
\text { Clay. } \\
\text { mont } \\
\text { Clay } \\
\text { mine. } \\
\text { Conl } \\
\text { Canyon). }\end{array}$ & 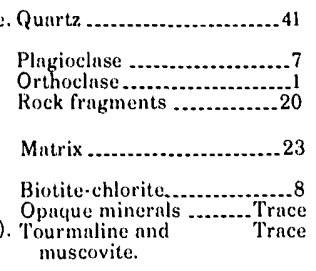 & $\begin{array}{l}\text { Sedimentary (Bedford Canyon? Formation) } \\
\text { and plutonic rocks. } \\
\text { Clay, silica, chlorite, and microcrystalline } \\
\text { rock powder. }\end{array}$ \\
\hline $\begin{array}{l}\text { Sundstone. } \\
\text { unit B } \\
\text { (upper. } \\
\text { most } \\
\text { bed. } \\
\text { divide } \\
\text { between } \\
\text { Conl and } \\
\text { Fremont } \\
\text { Canyons). }\end{array}$ & $\begin{array}{l}\text { Quartz } \\
\text { Biotite } \ldots \ldots \ldots \ldots \\
\text {. }\end{array}$ & Altered. \\
\hline $\begin{array}{l}\text { Cluys } \\
\text { unit } \mathrm{C} \\
\text { (lower } \\
0.6 \mathrm{m:} \\
\text { north } \\
\text { of Baker } \\
\text { Canyon). }\end{array}$ & $\begin{array}{l}\text { Kanolinite .................. } \\
\text { Quartz } \\
\text { Tourmaline............... Trace } \\
\text { Opaque minerals............. }\end{array}$ & $\begin{array}{l}7 \text { percent pisolites } 73 \text { percent matrix. } \\
\text { In matrix and pisolites. }\end{array}$ \\
\hline $\begin{array}{l}\text { Clay. } \\
\text { unit C } \\
\text { (opposite } \\
\text { Mod. } \\
\text { jesku). }\end{array}$ & $\begin{array}{l}\text { Kuolinite } \ldots \ldots \ldots \ldots \ldots \ldots \ldots . . .72 \\
\text { Quurtz }\end{array}$ & $\begin{array}{l}\text { Matrix. } \\
\text { Grains up to } 1.34 \text { mm diameter; a few partially } \\
\text { replaced by kaolinite. }\end{array}$ \\
\hline $\begin{array}{l}\text { Clay. } \\
\text { unit C } \\
\text { (from } \\
\text { Snntiago } \\
\text { Truck } \\
\text { Truil). }\end{array}$ & 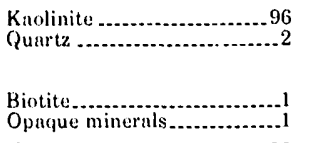 & $\begin{array}{l}\text { Matrix. } \\
\text { Grains up to } 0.6 \mathrm{~mm} \text { diameter; partially } \\
\text { replaced } \\
\text { by kaolinite. }\end{array}$ \\
\hline $\begin{array}{l}\text { Cluy. } \\
\text { unit C } \\
(\text { near } \\
\text { section A } \\
\text { plate 4). }\end{array}$ & 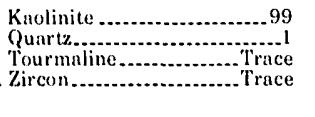 & $\begin{array}{l}\text { Pisolites, maximum diameter } 3.4 \mathrm{~mm} \text {. } \\
\text { Grains, maximum diameter } 0.6 \mathrm{~mm} \text {. }\end{array}$ \\
\hline $\begin{array}{l}\text { Clay, } \\
\text { unit C } \\
\text { (lower } \\
0.6 \mathrm{~m} . \\
\text { divide } \\
\text { between } \\
\text { Gypsum } \\
\text { and } \\
\text { Fremont } \\
\text { Canyons). }\end{array}$ & 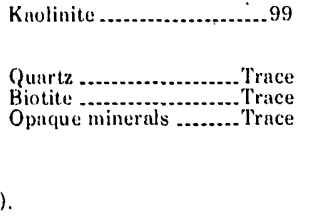 & $\begin{array}{l}16 \text { percent birefringent pisolites, } 7 \text { percent } \\
\text { birefringent and after quartz. } 76 \text { percent } \\
\text { matrix. }\end{array}$ \\
\hline $\begin{array}{l}\text { Clay, } \\
\text { unit c } \\
\text { (divide } \\
\text { between } \\
\text { Gypsum } \\
\text { And } \\
\text { Fremont } \\
\text { Cinyons. } \\
1.8 \mathrm{~m} \\
\text { nbove } \\
\text { buse). }\end{array}$ & $\begin{array}{l}\text { Kandinite } \\
\text { Quntz } \\
\text { Opactue minerals................. }\end{array}$ & $\begin{array}{l}\text { Corroded and partly replaced by kaolinite; } \\
\text { Limonite? }\end{array}$ \\
\hline $\begin{array}{l}\text { Clay. } \\
\text { unit C } \\
\text { (top. } \\
\text { ridge } \\
\text { between } \\
\text { Gypsum } \\
\text { and } \\
\text { Fremont }\end{array}$ & 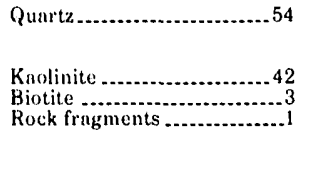 & $\begin{array}{l}\text { Corroded and partly replaced by kaolinite; } \\
\text { unusually coarse and up to } 2 \mathrm{~mm} \text { in } \\
\text { diameter. } \\
\text { More or less altered. }\end{array}$ \\
\hline
\end{tabular}

unique fiery red. Outside these mountains it is present for several kilometers to the east, near Elsinore, and for many kilometers to the south, where clay miners call it "tierra colorado." Variegated beds in Silverado Formation in the San Joaquin Hills to the southwest possibly are equivalent to this part of the section (Vedder, 1975).

The Claymont Clay Bed is 20 to. $55 \mathrm{~m}$ above the base of the Silverado Formation ( pl. 4); it is commonly about $1 \mathrm{~m}$ thick but reaches a maximum of $3 \mathrm{~m}$. Its composition and economic importance have been described by Sutherland (1935) and Burchfiel and Mulryan (1940). The Claymont is not present either in the western part of Irvine Block 34 (southeast of Gypsum Canyon) or at the north edge of the mountains, just south of the Santa Ana River.

The Claymont Clay Bed is yellow brown or greenish gray and weathers red (fig. 12). It is massive and unstratified. It contains angular quartz grains as much as $2 \mathrm{~mm}$ across; in most places it contains balls or irregu. lar clasts of distinctive clay up to $12 \mathrm{~mm}$ across, some nearly spherical, some with pisolitic shells, and some containing altered fragments of the Bedford Canyon Formation. The pisolites (figs. 13A, B) are commonly deep brown and darker than the matrix; some pisolites near the base of the unit are white.

Flakes of golden-yellow kaolinite after biotite and angular quartz grains are commonly present in the lower part of the clay bed. Vertical variations in the size of the quartz grains are not noticeable in the outcrop; in areas where the clay is very pisolitic, the pisolites tend to be more abundant in the middle of the bed. However, lateral variations in the amount of quartz and changes in the proportion of pisolites are abrupt. In several areas the uppermost part of the Claymont Clay Bed is a white to light-gray, very sandy, quartzose claystone that grades downward into the typical yellow quartzose claystone. The upper contact of the Claymont, though poorly exposed, appears to range from gradational to disconformable.

Near Claymont, in the western part of Irvine Ranch Block 34 , the clay has been quarried. There, the typically yellow Claymont Clay Bed grades upward within about $8 \mathrm{~cm}$ to a gray claystone $0.5 \mathrm{~m}$ thick that is overlain by $0.5 \mathrm{~m}$ of sandstone which in turn is overlain by another $1.5 \mathrm{~m}$ of gray silty claystone. In this area the top of the Claymont is placed arbitrarily at the base of the lowest prominent sandstone bed. About a hundred meters northeast, a channel-filling sandstone cuts down into the clay, and the gray claystone is absent. The only other place where gray silty claystone grada. tionally overlies the typically yellow Claymont is along the Santiago Truck Trail on the Santiago-Aliso divide. On the prominent ridge just southeast of Baker Can- 
yon, a bed of conglomeratic sandstone truncates part of the underlying Claymont, indicating a local conformity. From Baker Canyon northwestward toward Black Star Canyon, a dark-gray to black carbonaceous shale and siltstone bed locally overlies the Claymont Clay Bed, which here is very sandy.

PETROGRAPHY

The Claymont Clay Bed is composed of the clay mineral kaolinite, as shown by X-ray diffraction study. In thin sections two varieties appear: one yellow brown and apparently isotropic, the other colorless with $\delta-a$ about 0.006 . The quartz grains are corroded and replaced by kaolinite (compare Ross and Kerr, 1931, p. 174 , pl. 43c, d; Listsyna, 1957, p. 862-865). Biotite in various stages of alteration to kaolinite is present. Feldspar is absent. Trace minerals include tourmaline, zircon, and pyroxene.
Thin sections show the variations in the Claymont Clay Bed (table 5). Two are from the lowest $30 \mathrm{~cm}$, one within $60 \mathrm{~cm}$ of the base, and three about $2 \mathrm{~m}$ above the base, near the top of the clay. One basal sample (fig. 14A, from section E, pl. 4) is almost all yellowbrown or colorless kaolinite, in part pisolitic; the other (fig 13A; near section A, pl. 4) is almost completely pisolitic clay (table 5). A yellowish-brown clay from the lower $60 \mathrm{~cm}$ (fig. 13B; section G, pl. 4) is almost all kaolinite (table 5). One section from yellow clay $2 \mathrm{~m}$ above the base is almost all kaolin (table 5), and one from the very top of the clay near Claymont (fig. 14b; section C, pl. 4) is about 40 percent kaolinite (table 5). A section from the lower $0.6 \mathrm{~m}$ of the clay in the central part of Irvine Ranch Block 114, north of Baker Canyon, $2.7 \mathrm{~km}$ from its mouth, is four-fifths kaolinite (table 5). Two thin sections represent the clay in the southeasternmost part of the map area. A yellowish-brown

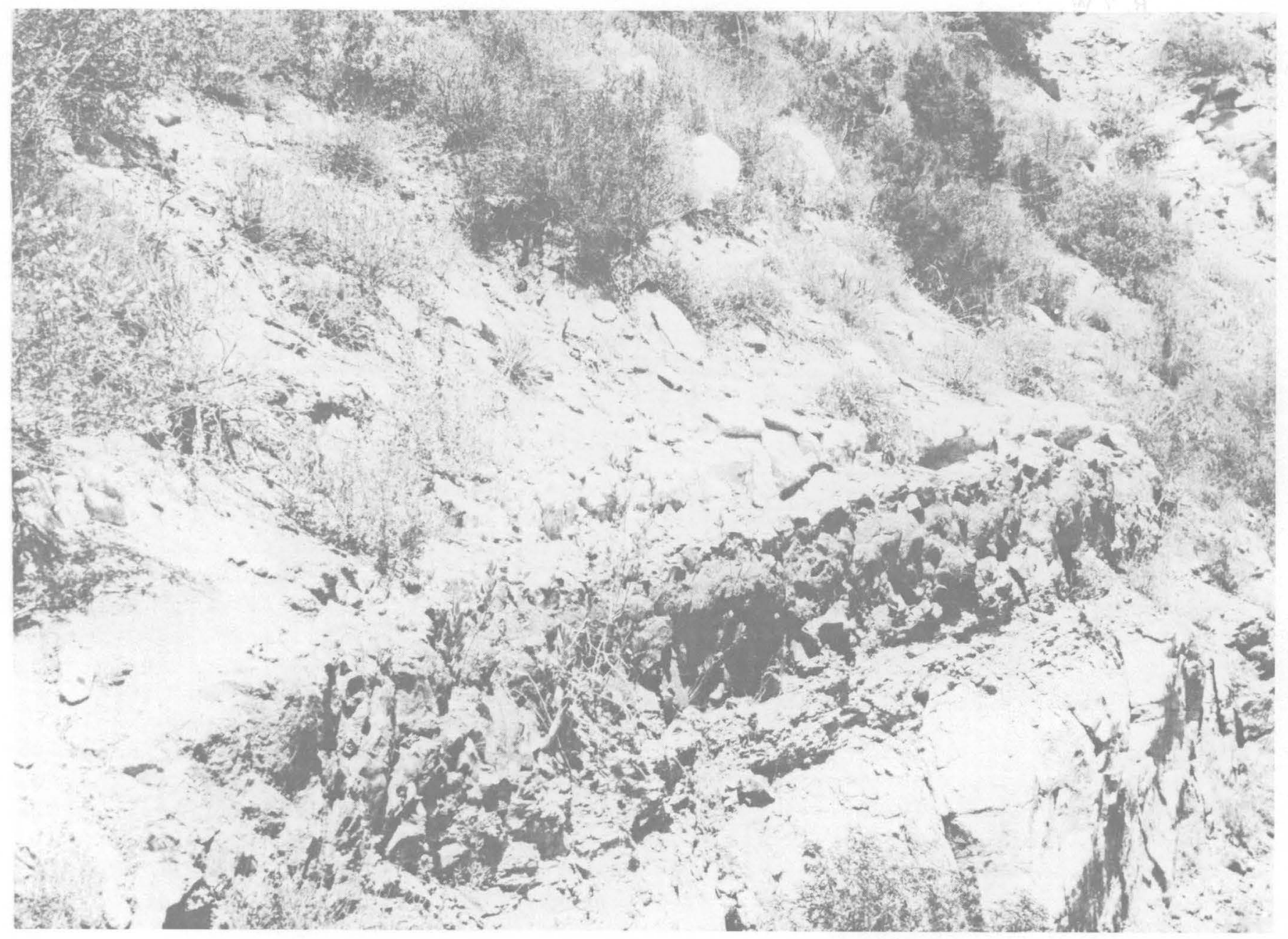

FIGURE 12.- The Claymont Clay Bed (below center) on Gypsum.Fremont Canyons divide; east quarter corner of Irvine Block 34 . Claymont Clay Bed is reddish brown, pisolitic, and about $3 \mathrm{~m}$ thick. View north. 
clay from the southwest bank of Santiago Creek, opposite Modjeska, is 72 percent kaolinite (table 5); another section, from the Santiago Truck Trail, still
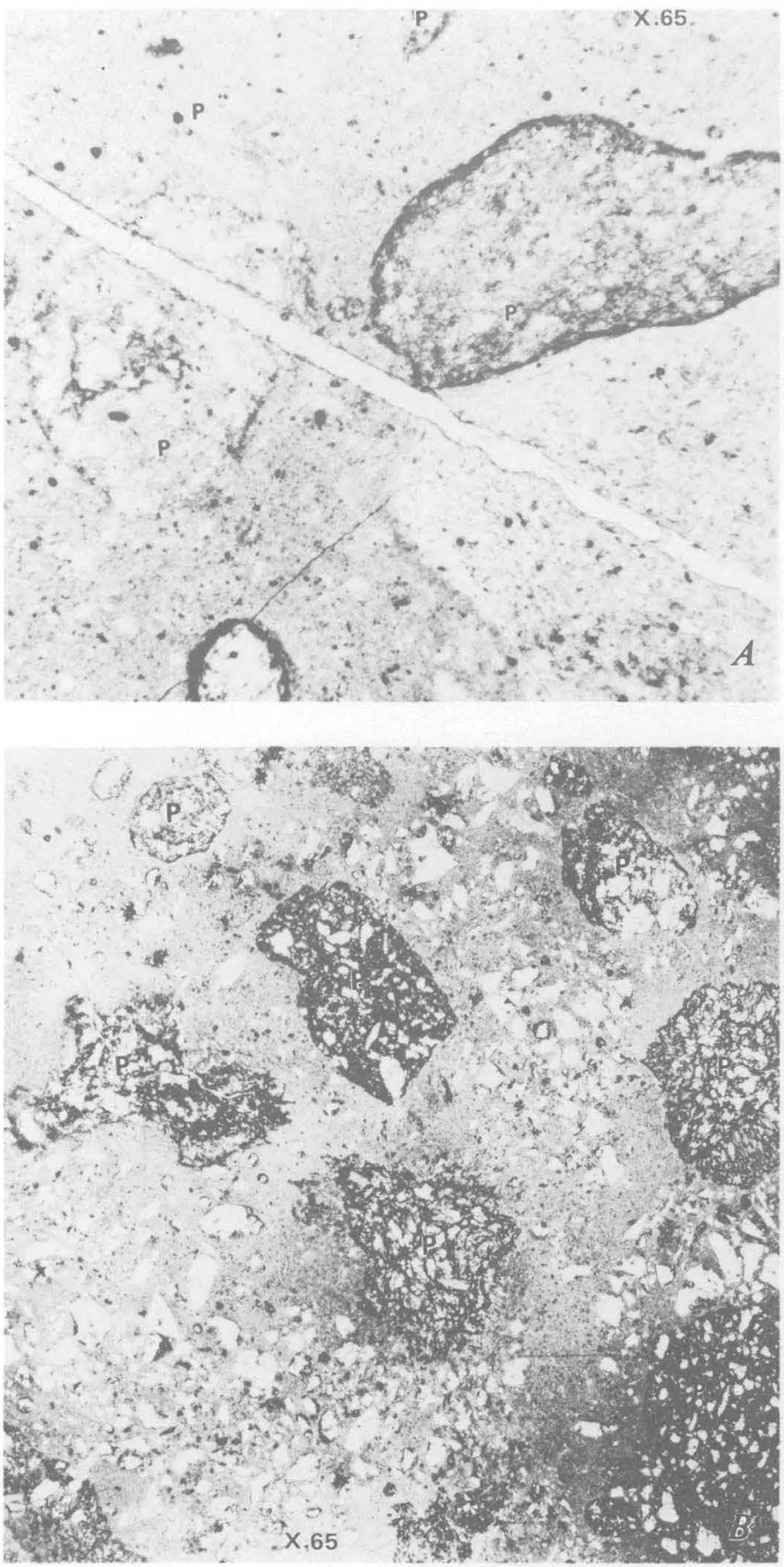

FigURE 13.- Photomicrographs of the Claymont Clay. A, Basal part of bed, $60 \mathrm{~m}$ east of measured section A ( pl. 4). Kaolinite forms 99 percent of rock as pisolites and matrix, plus clastic fragments of quartz and altered biotite. $\mathrm{P}$, pisolites. $B$, Basal part of bed measured section G ( pl. 4), lower 0.6 m of clay. Quartz common with uniform distribution in both kaolinite matrix and pisolites; opaque minerals few, tourmaline. P, pisolites. farther south, is also yellowish brown and is 97 percent yellow-brown to colorless kaolinite (table 5 ).
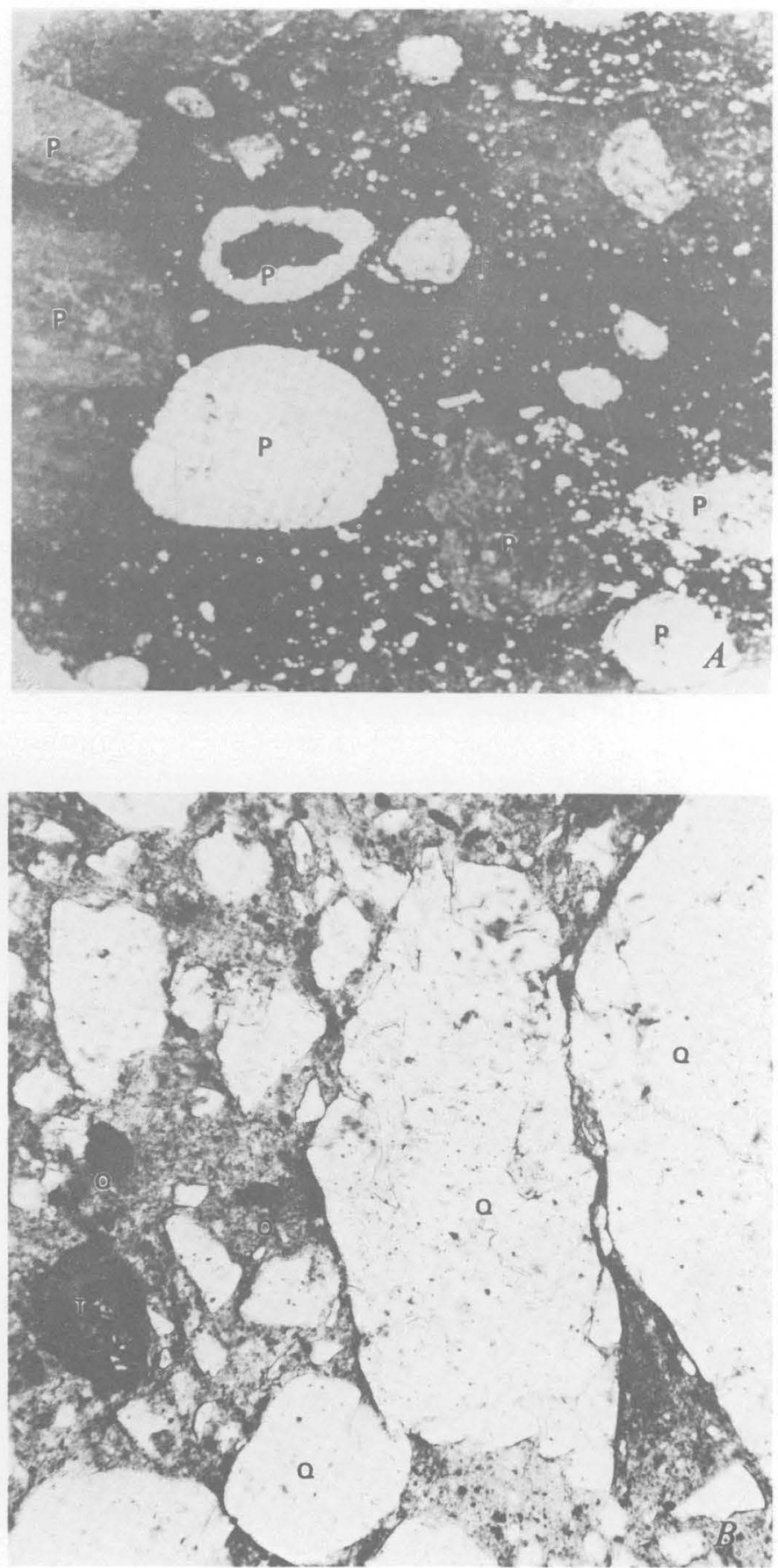

Figure 14.- Photomicrographs of the Claymont Clay. A, Basal part of bed, measured stratigraphic section $\mathrm{E}$ ( $\mathrm{pl} .4$ ); quartz-free kaolinite, as pisolites and matrix, and highly altered biotite, zircon, and iron oxide; $\mathrm{P}$, pisolites. $B$, Quartz-rich upper part of bed, measured stratigraphic section c (pl. 4). Q, quartz; T, tourmaline; $\mathrm{O}$, opaque minerals; with clay matrix. 
UNIT D, UPPERMOST SANDSTONE, SILTSTONE, AND CONGLOMERATE; SERRANO CLAY BED

In the type region of the Silverado Formation the strata of unit D directly above the Claymont Clay Bed are similar to those below it and are considered to be nonmarine. One hundred or so meters higher, here and elsewhere north of lower Santiago Creek, strata containing moderately well preserved brackish-water and marine fossils overlie the nonmarine beds above the Claymont. Southeast of Black Star Canyon, however, fossils have not been found in this formation. Unit D varies so greatly from place to place that it will be described under five headings, as follows: type region northeast of Irvine Park; northeast of Irvine Lake; north-central area - Fremont Canyon to the Santa Ana River; northeast of Whittier fault; and area southeast of Black Star Canyon.

\section{TYPE RECION NORTHLAST OF IRINE: PARK}

In the type region of the Silverado Formation the first $110 \mathrm{~m}$ of unit $\mathrm{D}$ above the Claymont Clay Bed is crosslaminated sandstone beds that contain abundant feldspar and biotite. The biotite in some beds has weathered golden yellow; in others it is fresh, black, and shiny. At about $110 \mathrm{~m}$ above the Claymont oysters and other brackish-water fossils are present. Several meters higher, the first two of several beds of carbonaceous shale occur.

The uppermost $120 \mathrm{~m}$ of calcareous, fine- to medium-grained sandstone is probably entirely marine. Several calcareous beds contain marine fossils but are less resistant to erosion than the underlying strata. Woodring and Popenoe (1945) collected the Paleocene guide fossils Turritella pachecoensis and Perissolax tricarnatus in or near the lower part of these beds, 250 $m$ west of their measured section.

NORTHIAST OF IRVINE LAKE

Unit D is as much as $430 \mathrm{~m}$ thick in this area. As in the type region of the Silverado Formation, the principal coaly bed is about $120 \mathrm{~m}$ above the Claymont Clay Bed, and a second carbonaceous shale and lignite bed is about $60 \mathrm{~m}$ higher. Poorly preserved marine or brackish-water bivalves and gastropods occur between the lignite beds. Locally these fossiliferous beds are composed almost entirely of shells, and an oyster bed is also present on the ridge immediately north of the mouth of Black Star Canyon. A ridge $400 \mathrm{~m}$ east of the type section is formed by a completely silicified sandstone bed $6 \mathrm{~m}$ thick.
During the latter part of the 19th century the carbonaceous shale and lignite beds were extensively prospected and locally mined for fuel. One of the largest operations was located at the old Santiago Coal Mine, where a total of 10 abandoned shafts attest to the mining activity in the area. These mines all apparently were developed in the upper of the two carbonaceous beds.

$$
\begin{gathered}
\text { North Central. AREA - Frimont Canyon } \\
\text { TO THE SANTA ANa River }
\end{gathered}
$$

The beds of unit $D$ in this area dip irregularly northwest in a section that is at least $180 \mathrm{~m}$ thick. Unit D here is mostly light-gray to buff sandstone. For a meter or so above the Claymont Clay Bed, the sandstone is very coarse grained, locally mottled red and white, and contains many golden-yellow flakes of kaolinite after biotite. A little higher in the section, finer grained sandstone beds contain greenish-black to black biotite that is locally so abundant that the rock resembles biotite schist. Lenticular beds of coarse-grained gritty sandstone as much as $2 \mathrm{~m}$ thick show large-scale crossbedding. Quartz is the principal mineral in most of the sequence; feldspar is present but minor. The matrix is clayey. Dark-brown concretions are locally present. Two, possibly three oyster beds occur about midway through the section. A thin section of a sample from the lowest of these beds is mostly fine-grained or coarsely crystalline calcite but includes many corroded quartz grains and some feldspar, both sanidine and oligoclase. Followed north, the underlying Claymont Clay Bed seems to disappear about $2 \mathrm{~km}$ south of the mouth of Coal Canyon. In this northern stretch, northeast of BM 1063, the lowest recognized oyster bed is slightly less than $90 \mathrm{~m}$ above the base of the Silverado Formation.

In the eastern part of Irvine Ranch Block 27, $2.5 \mathrm{~km}$ south of the mouth of Coal Canyon, above the highest oyster bed, a local conglomerate 1 to $5 \mathrm{~m}$ thick marks the change from coarse-grained buff sandstone below to the finer grained greenish-gray micaceous sandstone typical of the upper, marine part of the Silverado Formation. About $2 \mathrm{~km}$ farther north, $180 \mathrm{~m}$ northwest of BM 1063, a similar conglomerate that may be at the same horizon (Woodford and Gander, 1977) provided the lowest known accumulation of the rhyolitic and other metatuffs called Poway-type clasts by Woodford and others (1972).

The composition of the conglomerate is:

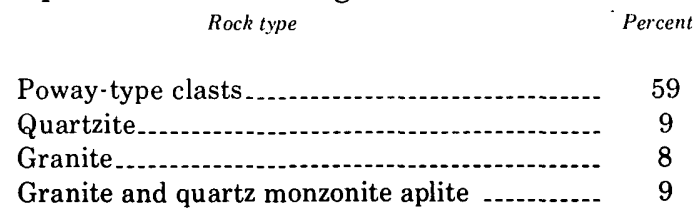




\begin{tabular}{|c|c|}
\hline Rock type & Percen \\
\hline Granite porphyry & - \\
\hline Granite gneiss & \\
\hline Granodiorite and quartz monzonite & \\
\hline Sandstone ....- & \\
\hline
\end{tabular}

The upper sandstone beds are well exposed at the south edge of the Riverside Freeway in Santa Ana Canyon, $260 \mathrm{~m}$ south and $6.1 \mathrm{~km}$ west of the northeast corner of the Black Star quadrangle, where they contain marine mollusks (locally F84).

Along and just south of Santa Ana Canyon the uppermost fossiliferous marine part of the Silverado Formation is overlain by the basal conglomerate of the Eocene Santiago Formation. At the top, $505 \mathrm{~m}$ northwest of BM 1063, a diagnostic Paleocene fossil assemblage was collected (locality F86). Farther southwest, in a tributary of Gypsum Canyon, a Paleocene shell bed (locality F88) was eroded slightly before sandstone at the base of the Eocene section was deposited.

\section{NORITHAST OF WHITTHR FAHTI}

In an east-striking fault slice at the northeast corner of the map area, a strip of the Silverado Formation 3 $\mathrm{km}$ long dips steeply north at places but is mostly overturned so that steep southward dips are the most prevalent. The section is at least $250 \mathrm{~m}$ thick. Its lower part is composed of fine- to coarse-grained gritty conglomeratic sandstone beds that are white to yellowish brown, greenish red, and reddish brown. Biotite is abundant. These beds resemble those of unit $D$ just above the Claymont Clay Bed in more complete sequences. Overlying them are interbedded buff sandstone and conglomerate, with poorly preserved oysters near their base. Locally the conglomerate contains reddish volcanic clasts like those in the local conglomerate above the oyster beds in the north central area. The micaceous sandstone and interbedded siltstone above this conglomerate locally contain poorly preserved marine mollusks. In a small fault sliver 300 $m$ south of the west end of the strip, a diagnostic marine molluscan fauna is present (locality F85).

In ridges at the east end of the strip, east of Fresno Canyon, interbedded white to buff coarse-grained sandstone, gray and yellowish-gray siltstone, and buff conglomerate grade upward into poorly sorted quartzfeldspar-biotite pebbly sandstone, in part well cemented. Just east of the map area these beds grade upward into a thick sequence of clay-rich beds not exposed elsewhere in the Silverado Formation (Gray, 1961), which contain well-preserved Turritella pachecoensis, a strongly noded form (locality F83).
AREA SOT "I7HLAS" OF

BLACK STAR CANYOX

The Silverado Formation is continuously but poorly exposed from the mouth of Black Star Canyon southeastward to the east edge of the map area. Outcrops on the prominent ridge $520 \mathrm{~m}$ southeast of Baker Canyon indicate the general character of the formation north of Silverado Canyon. In these outcrops the Claymont Clay Bed is overlain directly by about $1 \mathrm{~m}$ of unit D clayey conglomeratic sandstone that contains abundant golden-yellow kaolinite after biotite, whereas im. mediately northwest of Baker Canyon unit D car. bonaceous shale rests directly on the clay. Above the sandstone is about $20 \mathrm{~m}$ of buff poorly sorted coarsegrained biotitic sandstone and interbedded sandy siltstone which ranges in color from greenish gray to maroon. Gradationally overlying these varicolored beds is about $40 \mathrm{~m}$ of soft greenish-gray micaceous fine- to medium-grained sandstone and interbedded siltstone and sandy siltstone. Gray calcareous concretions, weathered dark brown, are common in this sandstonesiltstone sequence, but none of these contain evident fossils, though this interval is similar lithologically to the marine sequence north of Irvine Park where the concretions are fossiliferous. This concretionary unit is overlain by about $10 \mathrm{~m}$ of poorly sorted clayey sandstone with a waxy. clayey matrix that is more abundant in the upper part. The lower part contains relatively fresh biotite; biotite in the upper part appears as books and flakes of pale greenish-gray mica and is more altered and weathered. The entire ridge section is about $75 \mathrm{~m}$ thick and presumably is chiefly nonmarine.

The ridge section described above includes the Serrano Clay Bed, which in turn is overlain by about 120 $m$ of strata assigned to the upper part of the Silverado Formation. This sequence is traceable to the southeast corner of the map area. The Serrano Clay Bed is about $1 \mathrm{~m}$ thick and is composed of about 50 percent un. sorted and randomly distributed angular quartz grains in a matrix of light-gray to white clay. Unlike the Claymont Clay Bed, it is soft and plastic. Locally it is mottled pink, maroon, and purple. It is overlain by a thin bed of hard white quartz-rich and clayey fine- to medium-grained sandstone, in turn succeeded by $0.3 \mathrm{~m}$ of black laminated carbonaceous shale. Above the Serrano the uppermost $120 \mathrm{~m}$ of the Silverado Formation is gray and buff sandstone interbedded with some siltstone beds as much as $5 \mathrm{~m}$ thick. Fragments of silicified wood are locally common in the lower part of this sandy sequence. Near the upper contact, on the southeast side of Modjeska Road near its intersection with the Santiago Truck Trail, a massive white bed of sandstone contains a few scattered pebbles and cobbles. 


\section{AGE AND CORRELATION}

Molluscan assemblages of the Silverado Formation generally consist of few species. Three assemblages contain genera suggesting brackish water (localities F97, 98, 99). The following marine forms are common in the Santa Ana Mountains area: Turritella pachecoensis Stanton, strongly noded form, Turritella pachecoensis Stanton, and Cucullaea cf. C. mathewsonii Gabb. Other species are cited in the section "List of Megafossils."

Woodring and Popenoe (1945) considered their rather meager fauna from the area near Irvine Park to indicate a Paleocene age for the Silverado Formation. The presence of the typical Paleocene forms Brachysphingus cf. B. lyratus Gabb, Turritella pachecoensis Stanton, strongly noded form, and Cucullaea cf. $C$. mathewsonii $\mathrm{Gabb}$ in our collections from the upper part of the Silverado substantiates the Paleocene age assignment. The age of the lower part of the Silverado has not been determined on the basis of the brackishwater mollusks, but because it grades upward into and presumably intertongues with the marine strata and rests unconformably on Upper Cretaceous rocks, it is assigned a Paleocene age supporting the conclusion of Woodring and Popenoe (1945).

\section{EOCENE SERIES}

\section{SANTIAGO FORMATION}

Fossiliferous Eocene strata in the Santa Ana Mountains were first described by Dickerson (1914) and assigned by him to the Tejon Formation, the type locality of which is on the northeast side of the San Andreas fault near Fort Tejon, $160 \mathrm{~km}$ to the northwest. English (1926) followed the same usage and mapped several small areas of Eocene rocks between Santiago Creek and the Santa Ana River. Woodring and Popenoe (1945) measured stratigraphic sections and identified fossils from the Eocene strata in several parts of the northwestern Santa Ana Mountains. They proposed the name Santiago Formation for these strata, which they correlated with the upper half of the California Eocene.

The type region of the Santiago Formation is about 1 $\mathrm{km}$ northeast of Irvine Park, on the north side of Santiago Creek. Because we were unable to map an upper boundary of marine strata in the type region, we include in the Santiago about $600 \mathrm{~m}$ of massive buff to yellow sandstone that underlies the basal conglomerate of the undifferentiated Sespe and Vaqueros Formations. Presumably, the massive sandstone in the upper part of the Santiago is nonmarine; silicified wood commonly is present in it. The Santiago Formation throughout the map area rests on the Silverado Formation (fig. 15). At the southeast, where both are probably nonmarine, separation of the two is especially difficult.

The Santiago Formation occurs in relatively small areas, most of which are confined to three strips. The northeasternmost strip extends along the south side of the Santa Ana River; the second extends from the river southwest to Irvine Park; and the third lies along San. tiago Creek from Irvine Park to the southeast corner of the map area. Other small areas of outcrop are present in the southwestern foothills. Subsurface data are meager, largely because most wells bottom in beds above the Eocene section. Rubicon Oil Co. well, Wilcox No. 1, north of Burruel Ridge reached Eocene rocks as did Shoreline Oil Co. well, Pinkerton No. 1, southeast of Orange. Texas Co. well, A-13-1, $3 \mathrm{~km}$ west of Anaheim, $8 \mathrm{~km}$ west of the map edge, probably penetrated at least $100 \mathrm{~m}$ of the formation (Woodring and Popenoe, 1945: Schoellhamer and Woodford, 1951). The formation is absent from Amerada Petroleum Corp. well, Irvine No. 63-1, southeast of Tustin, and, in the same area, from Shell Oil Co., Irvine Core Holes Nos. 4 and 5. It probably is present in the subsurface near El Toro and crops out again farther southwest in the San Joaquin Hills (Vedder and others, 1957; Vedder, 1975).

The Santiago Formation may be thickest at the west. The westernmost unfaulted outcrop sequence is $820 \mathrm{~m}$ thick in the type region. Ten $\mathrm{km}$ farther west, between Orange and Santa Ana, the Shoreline Oil Co. well, Pin. kerton No. 1, bottomed in Eocene strata after penetrating $340 \mathrm{~m}$ of the formation. Northeast of the type region, near the head of Gypsum Canyon, the section is estimated to be about $250 \mathrm{~m}$ thick, and in the far northeast, north of the Whittier fault, a measured section is about $205 \mathrm{~m}$ thick. In the east-central area between Irvine Lake and the mouth of Black Star Canyon, the thickness is about $235 \mathrm{~m}$ and in the extreme southeast the formation is only $90 \mathrm{~m}$ thick and may be entirely nonmarine.

The lithology of the sedimentary rocks in the Santiago Formation suggests that their bulk was derived chiefly from the bedrock complex that crops out a few kilometers to the east, that most of the sandstone and siltstone consists of the products of the perhaps direct disintegration of basement rocks, but that the conglomerate is a concentrate of the more resistant elements in it, plus quartzite and metatuff of possibly distant origin.

Crossbedding, measured at 79 points in the Eocene outcrops close to Santiago Creek between the mouth of Fremont Canyon and Modjeska indicate current directions fairly close to due west (Davis, 1978). 
STRATIGRAPHY AND LITHOLOGY

BASAL CONGIOMERATH

In the type region of the Santiago Formation and northeastward to the head of Gypsum Canyon, the basal conglomerate is only 1.5 to $3 \mathrm{~m}$ thick. Sandstone is present at the base at the head of Gypsum Canyon rather than conglomerate. Along the south side of
Santa Ana Canyon north of the Whittier fault, the conglomerate thickens to a maximum of at least $68 \mathrm{~m}$ and contains clasts as much as 30 or $35 \mathrm{~cm}$ in diameter. Southeast from the type region, along Santiago Creek, the thickness is variable.

The pebbles and cobbles in the type region and east or southeast of it consist of as much as 40 percent
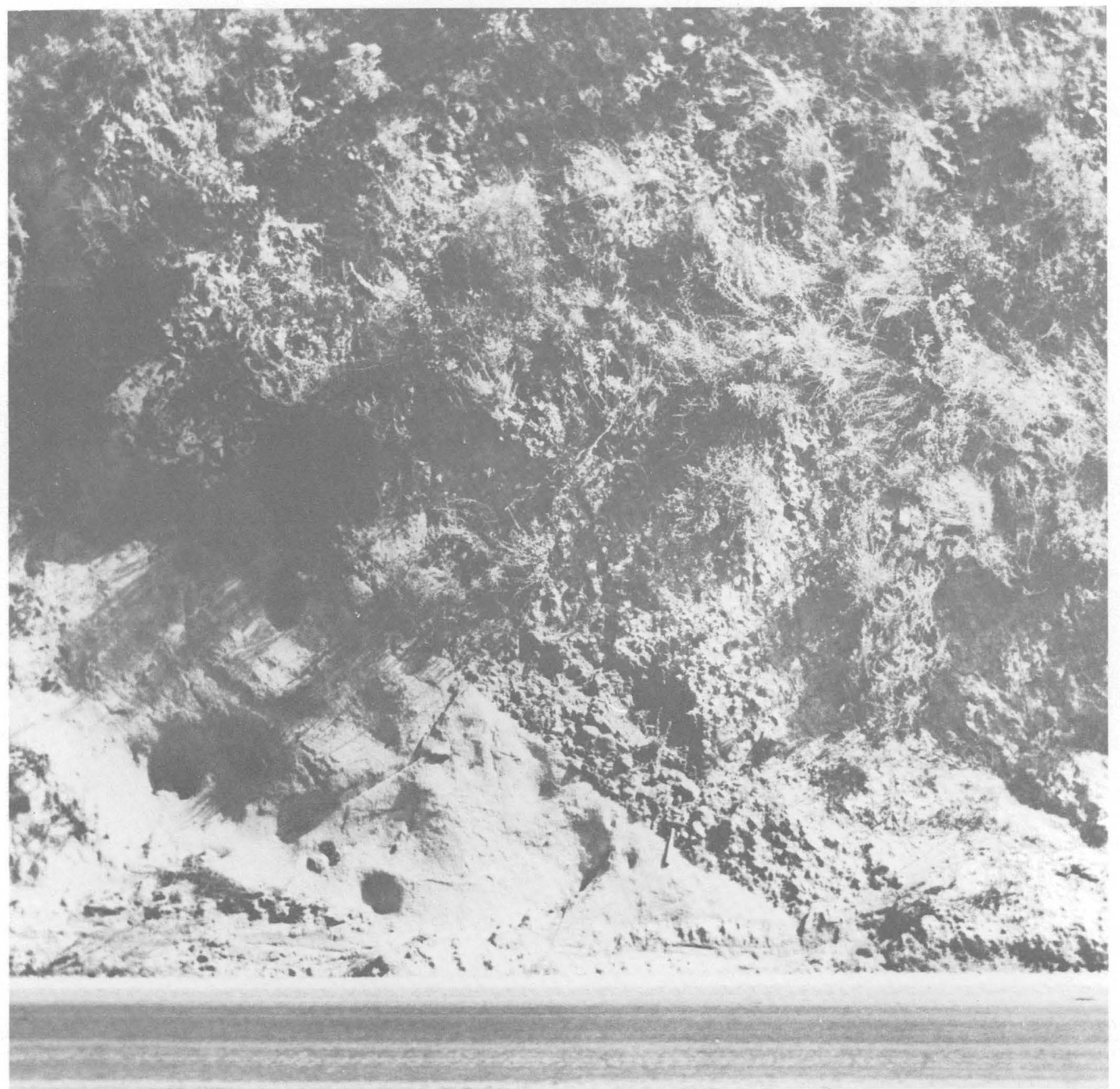

FIGURE 15.- Contact between basal conglomerate (at hammer) of Santiago Formation and sandstone of Silverado Formation. On south side of Santa Ana Canyon (now Riverside) Freeway just east of unnamed canyon in Irvine Block 30. View south. 
quartzite and include vein quartz, varicolored volcanic rocks, pale quartz plutonite and gneiss, hard sandstone, and metaconglomerate. Few if any pebbles or large clasts are of rock types that could have been derived from the Bedford Canyon Formation.

The basal conglomerate in and near Santa Ana Canyon, on both sides of the Whittier fault, is exceptional in composition as well as in thickness, with many clasts of siliceous metatuff (Woodford and others, 1968). Woodford studied a sample of 100 clasts larger than $2.5 \mathrm{~cm}$ diameter from south of the Whittier fault; 37 were studied in thin section and 16 analyzed chemically. Their compositions are given below. Almost all these clasts were quartz rich, and their textures make them resist disintegration. Farther west, between Coal and Gypsum Canyons, the basal conglomerate is much thinner, and the percentage of quartzite clasts much higher.

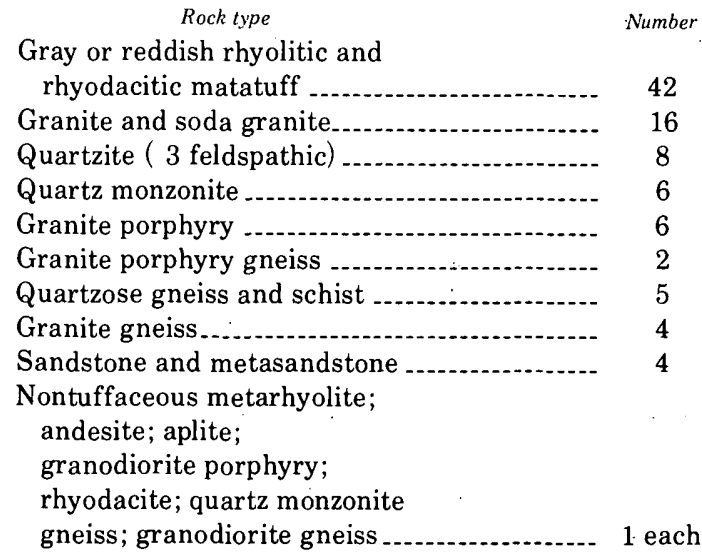

\section{STRATA ABOVE BASAL CONGLOMERATE}

Above the basal conglomerate the Santiago Formation is mostly gray to buff micaceous feldspathic sandstone interbedded with subsidiary siltstone. Carbonate-cemented sandstone concretions are $5 \mathrm{~cm}$ to $1 \mathrm{~m}$ in diameter; some contain marine mollusks, others, plant remains. Silicified wood is common in the higher, probably nonmarine, section.

\section{PETROGRAPHY}

Nine samples of the Santiago Formation were point counted in thin section. Two are from basal sandstone: one from the type region has clastic grains up to $6 \mathrm{~mm}$ across, and one, probably nonmarine, from the Santiago-Aliso divide at the far southeast has clastic grains up to $1.68 \mathrm{~mm}$ across (table 6).

Two sandstone samples are from the lower third of the formation: one from the south side of Santa Ana Canyon between Coal and Gypsum Canyons has clastic
TABLE 6. -Petrography of the Santiago Formation

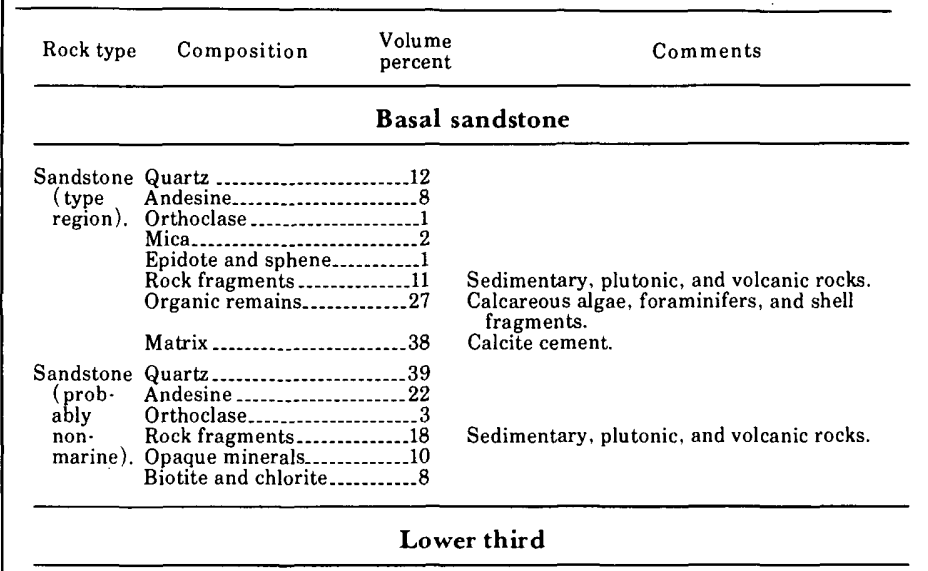

\begin{tabular}{|c|c|c|}
\hline $\begin{array}{l}\text { Sandstone } \\
\text { (Santa } \\
\text { Ana } \\
\text { Canyon). }\end{array}$ & $\begin{array}{l}\text { Quartz } \\
\text { Plagioclase } \\
\text { Orthoclase } \\
\text { Rock fragments } \\
\text { Biotite and chlorite .......Trace } \\
\text { Opaque minerals ..... } \\
\text { Epidote and muscovite..Trace } \\
\text { Matrix }\end{array}$ & $\begin{array}{l}\text { Calcite cement, replacing original clayey. } \\
\text { chloritic matrix. }\end{array}$ \\
\hline $\begin{array}{l}\text { Sandstone } \\
\text { (Little } \\
\text { Joaquin } \\
\text { Valley). }\end{array}$ & $\begin{array}{l}\text { Quartz } \\
\text { Andesine } \ldots . . . \\
\text { Orthoclase_- } \\
\text { Rock fragments } \\
\text { Matrix }\end{array}$ & $\begin{array}{l}\text { And untwinned oligoclase/andesine. } \\
\text { Sedimentary, plutonic, and volcanic rocks. } \\
\text { Micaceous, altering to clusters of minute }\end{array}$ \\
\hline . & $\begin{array}{l}\text { Biotite and chlorite } \\
\text { Muscovite } \\
\text { Opaque minerals. } \\
\text { Epidote. } \\
\text { Sphene, rutile, and zoisite }\end{array}$ & \\
\hline
\end{tabular}

\begin{tabular}{|c|c|c|}
\hline \multicolumn{3}{|c|}{ Middle third } \\
\hline $\begin{array}{l}\text { Sandstone } \\
\text { (Gypsum } \\
\text { Canyon) }\end{array}$ & $\begin{array}{l}\text { Quartz } \\
\text { n Andesine } \\
\text { Orthoclase } \\
\text { Biotite } \\
\text { Rock fragments } \\
\text { Matrix }\end{array}$ & $\begin{array}{l}\text { Sedimentary rocks. } \\
\text { Calcite cement, replacing original clayey. } \\
\text { micaceous matrix. }\end{array}$ \\
\hline $\begin{array}{l}\text { Sandstone } \\
\text { (Silver- } \\
\text { ado } \\
\text {. Canyon). }\end{array}$ & $\begin{array}{l}\text { Quartz } \\
\text { Andesine } \\
\text { Orthoclase } \\
\text { Rock fragments... } \\
\text { Biotite _... } \\
\text { Muscovite } \\
\text { Opaque minerals } \\
\text { Epidote } \\
\text { Sphene (and rutile?) } \\
\text { Matrix }\end{array}$ & Sedimientary, plutonic, and volcanic rocks. \\
\hline
\end{tabular}

Upper third

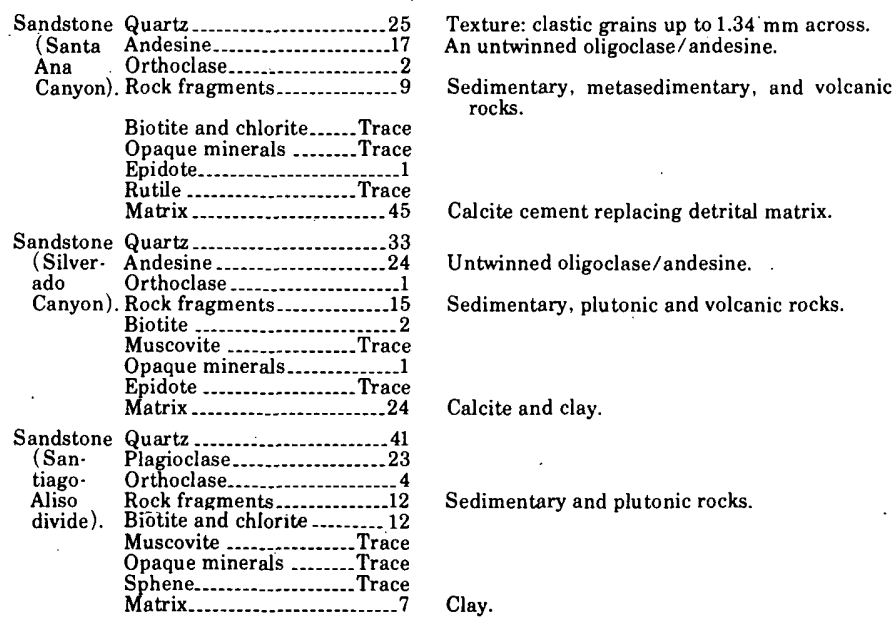


grains up to $1.47 \mathrm{~mm}$ across, and the other from Little Joaquin Valley has clastic grains up to $0.67 \mathrm{~mm}$ across (table 6).

Two probably marine sandstone samples are from the middle third of the formation: one from near the head of Gypsum Canyon has clastic grains up to $0.67 \mathrm{~mm}$ across, and the other from the north side of Silverado Canyon has clastic grains up to $0.64 \mathrm{~mm}$ across (table 6).

Two sandstone samples, the first probably nonmarine and the second surely so, are from the upper third of the formation. One from the south side of Santa Ana Canyon west of Coal Canyon has clastic grains up to $1.34 \mathrm{~mm}$ across, and the other from the south side of Silverado Canyon has clastic grains up to $1.54 \mathrm{~mm}$ across (table 6). Another nonmarine sample from the Santiago-Aliso divide $3 \mathrm{~m}$ below the top of the forma: tion has clastic grains up to $1.34 \mathrm{~mm}$ across (table 6).

\section{SIIBSUIRFACE DISTRIBUTION}

Subsurface data on the Santiago Formation are limited to a few wells. North of Burruel Ridge, electric-log characteristics of the Rubicon Oil Co. well, Wilcox No. 1 , indicate that at $1,762 \mathrm{~m}$ the hole passed from probable basal conglomerate of the undifferentiated Sespe and Vaqueros Formations, $23 \mathrm{~m}$ thick, into an alternating sequence of siltstone and fine-grained sandstone indicative of the Santiago Formation that extends to the bottom of the hole at 1,928 $\mathrm{m}$. Ditch cuttings below about $1,838 \mathrm{~m}$ are reported to contain foraminifers of Eocene age. The Texas Co. well, Ragan (NCT-1) No. 1, north of Santiago Creek near its debouchure from the mountains, passed from probable basal conglomerate of the undifferentiated Sespe and Vaqueros Formations into finer grained beds of the Santiago Formation at a depth of $1,100 \mathrm{~m}$. The base of the Eocene section here is missing because of normal faulting. The electric log and ditch samples indicate unfossiliferous fine-grained sandstone and siltstone interbedded with medium- to coarse-grained gray sandstone for the upper part of the unit. About $2 \mathrm{~km}$ southeast of Orange, Shoreline Oil Co. well, Pinkerton No. 1, passed from red beds of the undifferentiated Sespe and Vaqueros into coarse gray to black sandy siltstone and hard gray sandstone of the Santiago Formation at about $760 \mathrm{~m}$ depth. Eocene foraminifers and mollusk fragments were reported below $765 \mathrm{~m}$. The thick nonmarine sequence of the Santiago that crops out several kilometers to the east was not recognized in the Pinkerton well. This sequence may not be present in the subsurface of the Los Angeles basin, or its equivalent there may have been considered part of the undifferentiated Sespe and $\mathrm{Va}$ queros Formations.

\section{AGE AND CORRELATION}

The Santiago Formation contains fairly large mollus can and foraminiferal faunas. The fossils are mostly limited to the fine-grained concretionary strata in the lower part and to the basal sandstone and conglomerate where those are exposed north of Irvine Park.

Foraminiferal faunas. - Samples from the type region and from a quarry near the head of Gypsum Canyon (same as megafossil locality F100) were examined for foraminifers by M. C. Israelsky, who supplied the following report:

Foraminifers positively identified from the type region include: Amphistegina californica Cushman and M. A. Hanna, Cibicides mcmasteri Beck, and Haplophragmoides nonionelloides Israelsky. About $60 \mathrm{~m}$ of finegrained sandstone of the lower part of the Santiago Formation from the quarry yielded foraminiferal faunas that are similar throughout the section. These include Haplophragmoides nonionelloides Israelsky, Guadryina (Pseudogaudryina) coalingensis alata Israelsky, Massilina decorata Cushman, Amphimorphina californica Cushman and McMasters, Gyroidina simiensis Cushman and McMasters, Cibicides mcmastersi Beck, and C. pseudowellerstorffi Cole.

Woodring and Popenoe (1945) considered the molluscan fauna of the lower part of the Santiago Formation to be similar to that of the La Jolla Group farther south (Hanna, 1927; Kennedy and Moore, 1971).

The benthic foraminifers as well as the mollusks from the lower part of the Santiago Formation in addition to being similar to those of the La Jolla Group are also similar to those of the upper part of the Llajas Formation of the Ventura Basin, and the Domengine Formation of central California. These strata traditionally have been called middle Eocene by most California paleontologists. The identified benthic foraminifers from the lower part of the Santiago Formation are referable to the upper part of the Ulatisian Stage of Mallory (1959), and therefore may be correlated with the Discoaster sublodoensis nannoplankton zone (Poore, 1976).

\section{EOCENE(?) TO MIOCENE SERIES}

UPPER EOCENE(?) TO

LOWER MIOCENE

\section{SESPE AND VAQUEROS FORMATIONS, UNDIFFERENTIATED}

The Santiago Formation is overlain conformably by a varied sequence of interbedded marine and nonmarine sandstone and conglomerate assigned to the undifferentiated Sespe and Vaqueros Formations. The Sespe Formation was defined by Watts (1897) from its type 
locality along Sespe Creek, in the western part of the Transverse Ranges, $160 \mathrm{~km}$ northwest of the Santa Ana Mountains. The "Vaquero Sandstone" (Vaqueros Formation) was defined by Hamlin (1904, p. 14) from its type locality west of King City in the Santa Lucia Range, $420 \mathrm{~km}$ northwest of the Santa Ana Mountains. Both formations are present at many places in the Transverse Ranges, and also in the San Joaquin Hills southwest of the Santa Ana Mountains (Vedder and others, 1957). Although the marine Vaqueros commonly overlies the nonmarine Sespe in most of these areas, marine and nonmarine strata intertongue in the central Santa Monica Mountains as well as in the Santa Ana Mountains.

The interbedding of Sespe and Vaqueros Formations in the Santa Ana Mountains was first recognized by English (1926, p. 23-24). The Vaqueros Formation contains the shallow-marine Turritella inezana santana fauna and in general grades westward and southward into finer grained, deeper water sedimentary deposits.

The undifferentiated Sespe and Vaqueros Formations are exposed over a larger part of the northern Santa Ana Mountains than any other Tertiary or Mesozoic rock unit. Nearly continuous outcrops form an arc extending from the northeast to the southeast corners of the map area. Subsurface data in the area west of the outcrops are meager, for only a few wells have been deep enough to penetrate the undifferentiated Sespe and Vaqueros. However, these strata are probably present everywhere in the subsurface section beneath the western part of the map except in the vicinity of the Amerada Petroleum Corp. well, Irvine No. 63-1, and southeast of the northeast-trending fault between the Shell Oil Co. wells, Irvine Coreholes No. 4 and 5 (Yerkes and others, 1965, fig. 8).

Although reddish-stained outcrops generally seem to predominate in natural exposures of the combined unit in the Santa Ana Mountains, detailed examinations reveal that most beds are gray or pale buff rather than the deep reddish-brown hues characteristic of the Sespe Formation in its type locality. Beds containing marine fossils weather pale gray.

The undifferentiated Sespe and Vaqueros Formations range in thickness from 300 to $900 \mathrm{~m}$-thinnest near Weir Canyon, north of Santiago Creek and at about the midpoint of the outcrop arc, and thickest in the Peters Canyon area south of Santiago Creek. There are three principal lithologic subdivisions: (1) a basal conglomerate, present wherever the base is exposed, that ranges from a few tens to a hundred meters or so thick; (2) an overlying sandstone and conglomeratic sandstone which forms the main part of the unit; and (3) an upper conglomerate; that is about $200 \mathrm{~m}$ thick, present locally in northern part of the area.
The marine strata are limited to the southwestern part of the outcrop arc, southwest of a line extending east along the south side of Burruel Ridge, then crossing Santiago Creek at the Irvine Lake dam, and following the southwest side of Limestone Canyon to the east side of the slide area just south of The Sinks. The southeasternmost marine fossil locality, F139, is in the upper part of the section about $300 \mathrm{~m}$ above the base. The single locality that yielded terrestrial mammal remains is about $200 \mathrm{~m}$ above the base. Detailed correlations within the undifferentiated Sespe and Vaqueros, from the southern area north across Santiago Creek, are uncertain because of the limited outcrops and abrupt facies changes.

\section{STRATIGRAPHY AND LITHOLOGY}

Basal. Conglomerate

The buff, feldspathic, medium- to coarse-grained pebbly sandstone that occurs in the lowest part of the undifferentiated Sespe and Vaqueros Formations and in the upper part of the underlying Santiago Formation, lithologically very similar in some areas, makes recognition of the base of the undifferentiated Sespe and Vaqueros difficult. The contact is placed at the base of a sharply bounded dark-colored conglomerate (fig. 16), commonly 2 to $15 \mathrm{~m}$ thick and made up of closely packed, smooth pebbles and cobbles in a gray sandy matrix. In the northeast corner of the map area, north of the Whittier fault and east of Fresno Canyon, the thickness increases to about a hundred meters, and boulders a meter or so in diameter are numerous and are the largest anywhere in this basal conglomerate. The lithology here contrasts sharply with that of the marine sandstone in the underlying Santiago Formation.

The pebbles and cobbles in the basal conglomerate were sampled by Woodford and others (1968) in three places. One is at the edge of the Riverside Freeway on the south side of Santa Ana Canyon, 5,800 m west of long $117^{\circ} 37^{\prime} 30^{\prime \prime}$. The sample of 300 clasts, each identified in thin section, is made up as follows:

\begin{tabular}{|c|c|}
\hline Rock type & Perce \\
\hline $\begin{array}{l}\text { Poway type (rhyolitic and } \\
\text { other silicious metatuffs) }\end{array}$ & 54 \\
\hline Andesite and other volcanic rocks & 17 \\
\hline Quartzite and vein quartz & 11 \\
\hline Metamorphic rocks ............. & 6 \\
\hline Graywacke & 6 \\
\hline Aplite........... & 3 \\
\hline Granite porphyry & 2 \\
\hline Granite & 1 \\
\hline
\end{tabular}

The second locality is in Peters Canyon northeast of the lower dam. A sample of 100 clasts, each determined in thin section, is made up of: 
Rock type

Poway type
Quartzite
Granite
Volcanic porphyry
Aplite
Gneiss
Andesite
Graywacke

Of the 71 specimens of the general Poway type, 21 lack large quartz grains and have a completely recrystallized ground mass (Peters Canyon type). The sandy matrix at the Peters Canyon locality is about as follows:

Quartz

Volcanic rock

40

Potassium feldspar

Plagioclase

Quartzite

Quartz plutonite
Percent

8

5

3

The third locality is on the Bolero road just west of upper Santiago Creek. The hundred clasts, each examined in thin section, include:

$$
\text { Rock type }
$$

Percent

Poway type (soda rhyolite or similar

metatuff)

Unmetamorphosed andesite or other

volcanic rocks ( half are tuff)

Quartzite

Sandstone and siltstone

Granite or quartz-rich gneiss ....................... 7

Soda granite. 4

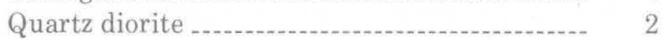

Aplite or pegmatite _... 4

Granite porphyry ..................... 2

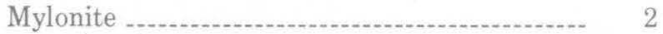

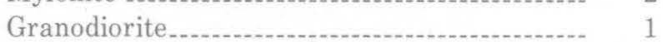

Vein or pegmatite quartz .............................. 1

The 500 pebbles and cobbles studied in thin section show: (1) an abundunce of siliceous metatuff and (2) a geographic variety of the rock types in the basal con-

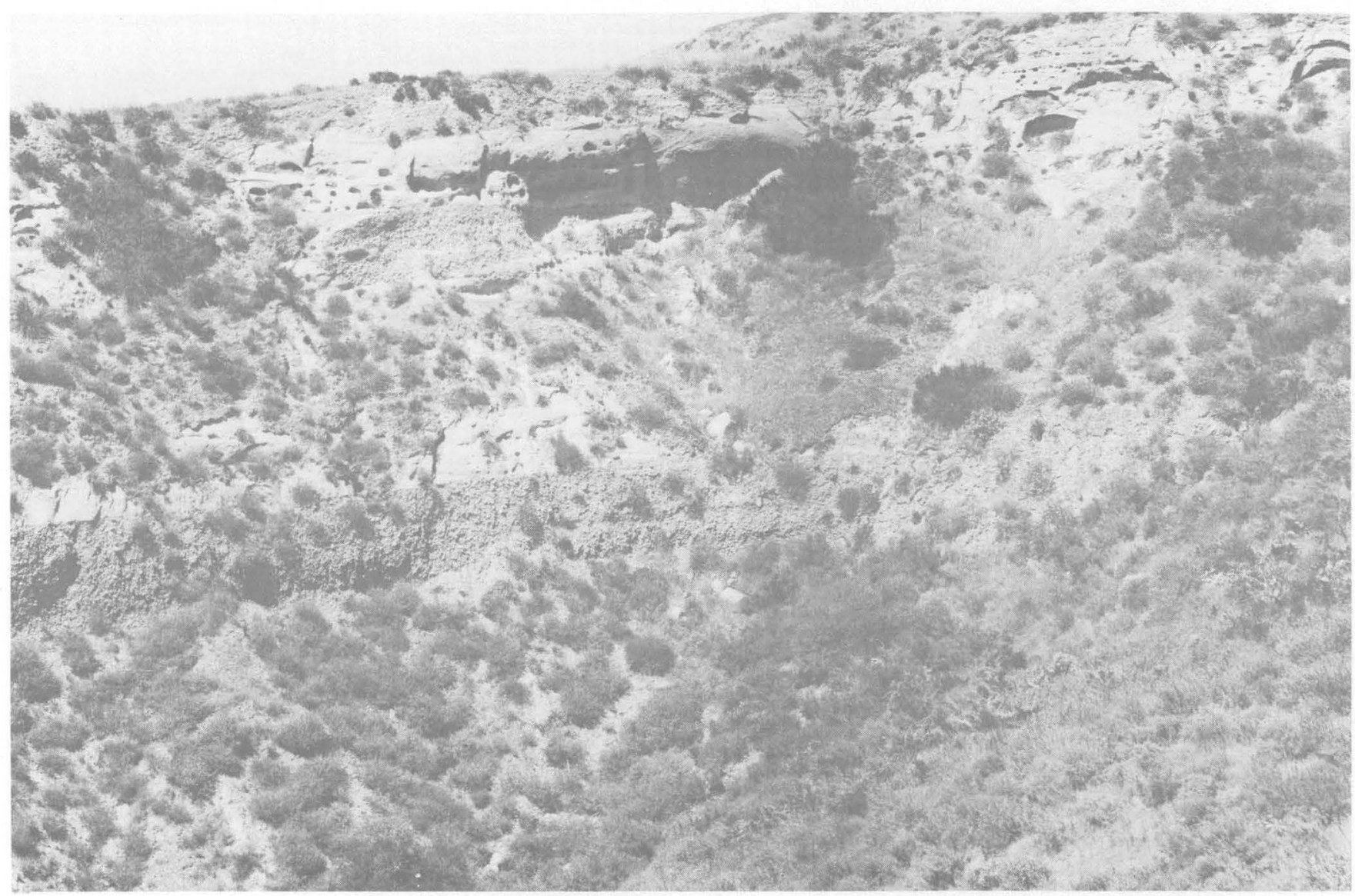

FIGURE 16.- Sharply bounded, dark-colored basal conglomerate (middle of photograph) of the undifferentiated Sespe and Vaqueros Formations overlying the Santiago Formation, east of Gypsum Canyon. Thickness of the undifferentiated Sespe and Vaqueros shown is about $30 \mathrm{~m}$. View north. 
glomerate. In general, the assemblages are composed predominantly of rhyolite or soda rhyolite metatuff, quartzite, and granite or soda granite. The rarity of quartz diorite or granodiorite similar to that of the Cretaceous batholith to the east is a striking feature.

\section{SANDSTONF. AND CONGLOMFRATIC SANDSTONE:}

The main part of the undifferentiated Sespe and Vaqueros Formations is composed of beds of reddish, gray, and buff to white feldspathic sandstone that contains numerous but scattered or isolated pebbles and cobbles. Many lenses of conglomerate are also present, however. In the northeast corner of the map area the sequence above the basal conglomerate is mostly yellow to white clayey feldspathic biotitic coarse-grained to conglomeratic sandstone, with a few brownish-red earthy sandstone layers, as well as stringers of pebbles and cobbles. Farther west, around Gypsum Canyon, the sandstone and conglomeratic sandstone is indistinctly bedded, yellowish-gray, tan, and buff sandstone, in part with a clayey matrix (upper part of fig. 16). Quartz is abundant, feldspar common, and crinkly biotite evident. Lenses of gravel include clasts as much as $0.3 \mathrm{~m}$ in diameter. At the top, the sandstone is poorly sorted, pinkish gray, and conglomeratic. Many fragments of granitic rock are contained in it. South of Burruel Ridge and north of Santiago Creek, around Weir Canyon, marine fossils are present in wellbedded, calcite-cemented, greenish-gray layers, interbedded with probable nonmarine strata similar to those around Gypsum Canyon.

The thickest section of the sandstone and conglomeratic sandstone is southwest of upper Santiago Creek, on both sides of Loma Ridge ( $\mathrm{pl} \mathrm{3,} \mathrm{structure}$ sections $R \cdot S$ and $U \cdot V)$, where the combined marine and nonmarine beds are about $900 \mathrm{~m}$ thick. The lower beds of the undifferentiated Sespe and Vaqueros Formations above the basal conglomerate are well exposed on the east limb of the synclinal bowl along upper Santiago Creek (fig. 17), where they are unfossiliferous, contain numerous red beds, and probably are wholly nonmarine. These beds are perhaps entirely pre-Miocene in age.

The upper beds of the sandstone and conglomeratic sandstone are fairly well exposed in an arc around Loma Ridge, from Peters Canyon and Rattlesnake Canyon to upper Limestone Canyon. These beds are alternating unfossiliferous yellowish, reddish, and greenish-gray sandstone and conglomerate, with thin interbeds of green and red sandy siltstone, and fossiliferous marine greenish-gray to white sandstone. The uppermost beds of the section are entirely marine, up to $1.5 \mathrm{~m}$ thick, calcareous, and contain Turritella inezana santana and many other mollusks as well as echinoid fragments.
In the vicinity of Bolero Lookout on the west side of upper Santiago Creek, a reddish-brown sandstone in the upper beds of the undifferentiated Sespe and Vaqueros Formations contains the guide gastropod Rapana vaquerosensis imperialis (locality F139). Not far away, in pinkish.gray sandstone, bone fragments of a late Oligocene(?) camelid associated with unworn shark teeth and ray teeth (locality V1) were found just below the top of the unit.

Thin sections of sandstone in Gypsum Canyon, representing the sandstone and conglomeratic sandstone from bottom to top, show the following ranges:

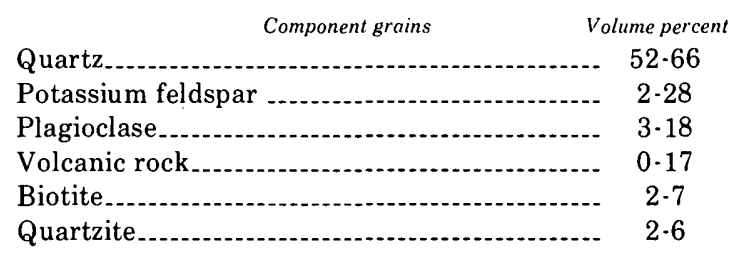

Conglomeratic layers in the sandstone of the main part of the unit were studied by Woodford and others (1968) at three locations. Clasts over $2.5 \mathrm{~cm}$ in diameter were similar to those in the basal conglomerate but show the following ranges:

\begin{tabular}{|c|c|}
\hline Rock types & Percent \\
\hline Poway type & $12 \cdot 66$ \\
\hline $\begin{array}{l}\text { Andesite and other } \\
\text { volcanic rocks }\end{array}$ & $5-22$ \\
\hline $\begin{array}{l}\text { Graywacke and other } \\
\text { sedimentary rocks }\end{array}$ & $1-19$ \\
\hline Quartz and vein quartz & $3 \cdot 17$ \\
\hline Quartz plutonite, mostly granite & $6 \cdot 16$ \\
\hline Gneiss & $12 \cdot 13$ \\
\hline Aplite & $2-5$ \\
\hline
\end{tabular}

UPPER CONGIOMLRATE

On the east side of Gypsum Canyon, just south of the Santa Ana River, the sandstone and conglomeratic sandstone grades abruptly upward into an upper massive conglomerate. Locally present is a solid mass of very crudely stratified, gray, closely packed, indurated gravel 150 to $180 \mathrm{~m}$ thick. The whole mass is the site of the Star Quarry of the Owl Rock Products Company. A fault striking N. $35^{\circ} \mathrm{E}$. splits the mass, the northwestern block apparently being downdropped slightly to the northwest. The gravel southeast of the fault is un. cemented, whereas drilling and blasting are required to prepare the gravel for easy excavation in the quarry to the northwest of the fault.

The conglomerate at the Star Quarry is composed chiefly of subangular clasts 3 to $18 \mathrm{~cm}$ in diameter in a sparse coarse gray sandy matrix (Woodford and others, 1972). A collection of 100 of these clasts, taken in 1975 southeast of the fault, was studied in thin section. Major rock types included: 


\begin{tabular}{|c|c|}
\hline \multicolumn{2}{|l|}{ Rock types } \\
\hline Poway type (metatuff) & $49(3$ \\
\hline 20 & with \\
\hline Quartzite................. & 16 \\
\hline Recrystallized tuff? & 9 \\
\hline Poway type (porphyry) & 5 \\
\hline Epidote-rich metamorphic rock ..- & 4 \\
\hline 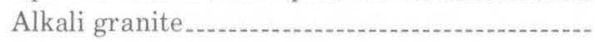 & 3 \\
\hline 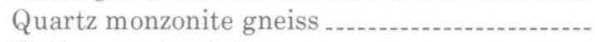 & 2 \\
\hline Tuffaceous sandstone & 2 \\
\hline Dacite porphyry & 2 \\
\hline Granite porphyry & 2 \\
\hline Tourmaline-quartz rock & 1 \\
\hline Alaskite & 1 \\
\hline Metasandstone, & \\
\hline Bedford Canyon(?) Formation -.............. & 1 \\
\hline $\begin{array}{l}\text { Leucogranodiorite } \\
\text { Feldspar-auartz rock }\end{array}$ & 1 \\
\hline Feldspar-quartz rock & 1 \\
\hline
\end{tabular}

The presence of probably more than 50 percent of Poway-type clasts is noteworthy and probably characteristic of this conglomerate. It generally is massive rather than well bedded. A very few short, thin lenses of feldspathic, biotitic sandstone demarcate the bedding. The few evident depositional features are sheets of fairly flat imbricated cobbles and sandstone crossbeds; each set suggests a source to the northeast.

In 1971-72 progressive eastward excavation of the Star Quarry passed through a lens of very coarse conglomerate 10 or so meters thick, probably somewhat above the middle of the section in the quarry. Hundreds of boulders are $1 \mathrm{~m}$ or more in diameter, and many exceed $2 \mathrm{~m}$. Some of these are smooth and ellipsoidal. The largest clast measured is a red Poway-type rock $198 \mathrm{~cm}$ long and about half that wide at its narrowest. Nearly 50 percent of the boulders, including all

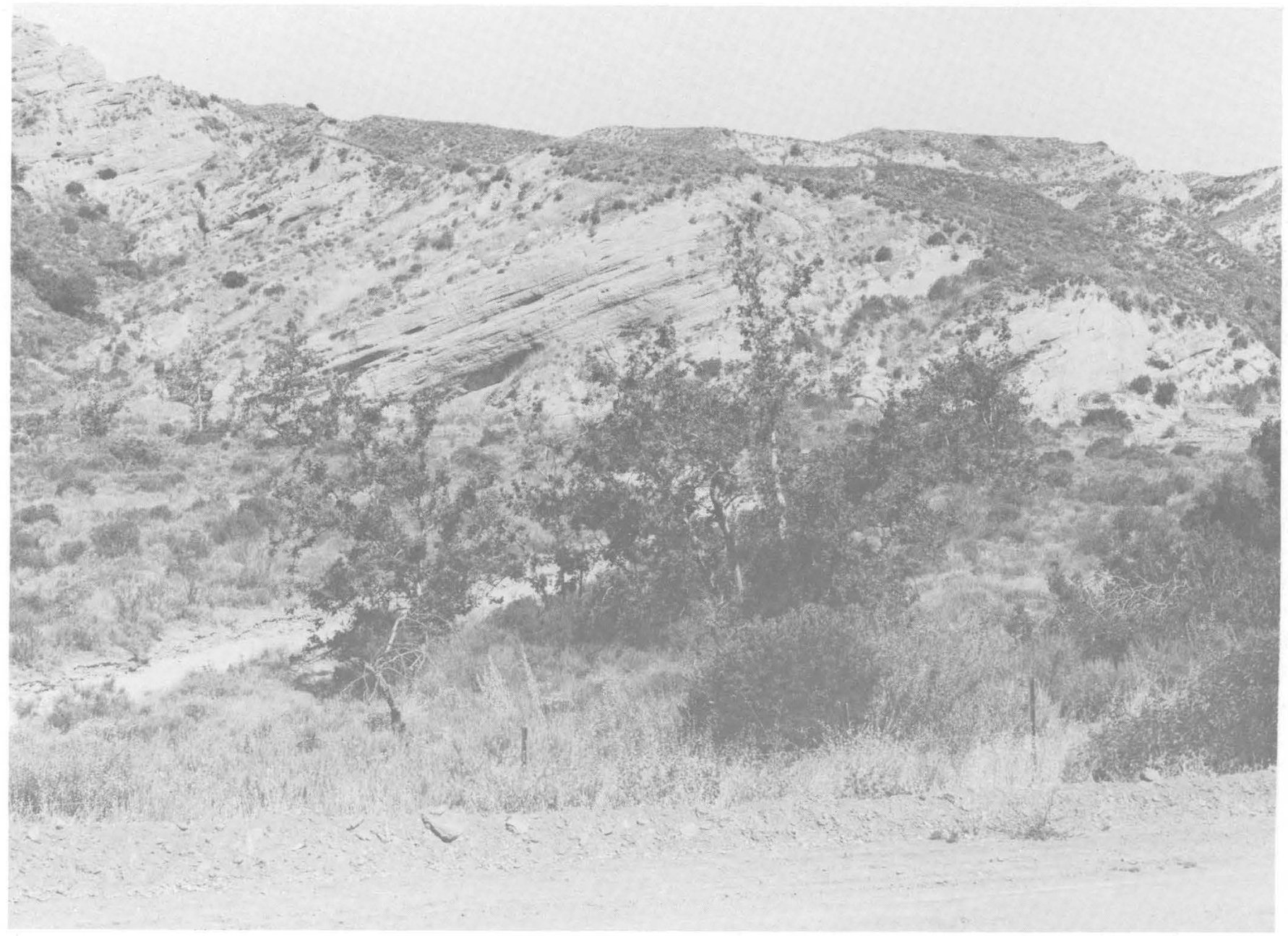

FiguRE 17.- Lower beds of the undifferentiated Sespe and Vaqueros Formations - reddish strata (upper left), creamy white strata (lower right). Top of hill (left) is about $60 \mathrm{~m}$ above stream bed. View west across Santiago Creek from Black Star Canyon Road. 
the very large ones, are rhyolite or soda rhyolite tuff of Poway type, many of them bright red with piemontite. The next commonest kind of big boulder is smoky-gray perthitic alkali granite with biotite. Boulders of gneiss and clear glassy pegmatite quartz (rarely with one flat face covered with biotite) are fairly common. No boulders of quartzite were seen. The granite is nearly identical to a perthitic granite or syenite found recently in the basement complex of the northwestern San Bernardino Mountains; both bedrock and boulders have radiometric ages near 170 m.y. (Terry Davis, oral commun., 1977).

\section{UPPER CONTACT}

The contact between the undifferentiated Sespe and Vaqueros Formations and the overlying Topanga Formation usually is easily recognized where the basal beds of the Topanga are fossiliferous conglomerate. The upper beds of the undifferentiated Sespe and Vaqueros, consisting of greenish-gray sandstone and silty sandstone and pinkish and reddish-brown sandstone, contrast sharply with the overlying buff and tan massive conglomeratic sandstone of the Topanga. No evidence of an angular discordance between the Topanga and underlying strata was found in the map area. The Topanga rests on various rock types of the Sespe and Vaqueros, probably as a result of changes from marine to nonmarine deposition within the Sespe and Vaqueros rather than of erosion prior to deposition of the Topanga. The contact between the Topanga and the Sespe and Vaqueros is a disconformity. In the hills east of $\mathrm{El}$ Modeno, the basal conglomerate of the Topanga is either missing or unrecognizable because of poor exposures, and the top of the Sespe and Vaqueros is placed at the top of the highest red beds. Only a short distance above this horizon, a molluscan fauna (F162) typical of the Topanga is present in fine-grained sandstone and siltstone; mollusks typical of the Sespe and Vaqueros (F140) are present below the contact. On Loma Ridge south of Irvine Lake, the Sespe and Vaqueros are unconformably overlain by well-laminated siltstone of the Puente Formation. Southeast of this area the Topanga again is present above the Sespe and Vaqueros.

\section{SUBSURFACE DISTRIBUTION}

Well data indicate that the undifferentiated Sespe and Vaqueros Formations are present in the area north of Burruel Ridge, in the vicinity of Orange, and southeastward to the fault between the Shell Oil Co. Irvine Coreholes No. 4 and No. 5 near El Toro Air Station. Throughout this lowland area the lithology of the Sespe and Vaqueros is similar to that in outcrop and consists of alternating greenish-gray, red and reddish-brown sandstone and conglomerate. North and west of Bur- ruel Ridge, the Sespe and Vaqueros are overlain by the Topanga Formation, whereas in the area southeast of Orange, sandy strata of probable Pliocene age directly overlie the Sespe and Vaqueros (structure sections $L-W, E \cdot L$, and $L-P$, pls. 2,3 ), and both the Topanga and Puente Formations are absent at the unconformity. A still older unconformity in this same area was revealed by the Shell Oil Co. corehole Irvine No. 4. The Sespe and Vaqueros in that well rest unconformably on the Williams Formation of Late Cretaceous age (structure section $T-X$, pl. 3). Northwest of Orange, deep wells have penetrated varicolored sandstone questionably assigned to the Sespe and Vaqueros sequence in an extensive area basinward from the Santa Ana Mountains. The northwesternmost of these is in the vicinity of the Leffingwell oil field near lat $32^{\circ} 55^{\prime} \mathrm{N}$., long $134^{\circ} 00^{\prime} \mathrm{W}$. (Yerkes and others, 1965, fig. 8 and pl. 4; Yerkes, 1972, pl. 2).

\section{AGE AND CORRELATION}

Fossils have not been found in the nonmarine lower beds of the undifferentiated Sespe and Vaqueros Formations. These beds may be as old as late Eocene.

A locality yielding mammal-bone fragments (VI) near Bolero Lookout, found by Chester Stock of the California Institute of Technology, was recollected and material submitted to G. Edward Lewis of the U. S. Geological Survey. Only three fragments, two upper molar fragments and one incomplete first phalanx, are questionably identifiable. Of these fragmentary specimens Lewis (written commun., 1955) states: "all three, although inconclusive, lead me to believe that they represent one of the early giraffe-like line of camelids. I have compared them with W. D. Matthew's type of Paratylopus primaevus at the American Museum in New York, and believe that they represent a closely related species of this genus. The stratigraphic position is most probably upper Oligocene, but possibly lower Miocene. A Sespe equivalent is indicated."

Marine invertebrate megafossils collected from the undifferentiated Sespe and Vaqueros Formations are cited in the megafossil lists. Echinoid species commonly include Kewia? fairbanksi santanensis; molluscan species include Rapana vaquerosensis imperialis, "Terebra" santana, and Anadara (Larkinia) santana. In the map area, these species are restricted to the unit and indicate a provincial early Miocene age.

\section{REGIONAL IMPORTANCE OF UPPER CONTACT}

Despite the near conformity of the undifferentiated Sespe and Vaqueros Formations and the Topanga Formation in and near the Santa Ana Mountains, the boundary between them marks a time of deformation and erosion in other parts of the Los Angeles basin. Before 
deposition of the Topanga Formation, a new regional landscape was initiated in southern California, and deformation and erosion in some areas outside the Santa Ana Mountains were increased. Soon therafter, the older sediments were either eroded away or deeply buried. The younger clastic sediments were derived from different types of rocks, in part coming from new sources. The impact of these changes was minimal in the Santa Ana Mountains; as a result, the Paleogene and early Miocene depositional record is more completely preserved there and in the San Joaquin Hills than in other areas south of the Transverse Ranges.

\section{MIOCENE SERIES}

MIDDLE MIOCENE

TOPANGA FORMATION

The Topanga Formation was first defined by Kew (1923, p. 416-417) for a predominantly sandstone sequence that crops out in Topanga Canyon in the Santa Monica Mountains and that contains the Turritella ocoyana fauna of provincial middle Miocene age. Kew (1923) recognized the presence of the Topanga Formation in the Puente Hills, Santa Ana Mountains, and San Joaquin Hills. English (1926) mapped the Topanga Formation in the Puente Hills and the northern part of the Santa Ana Mountains. English (1926, p. 24-25) considered the Topanga Formation to be the predominantly sandstone sequence that rests disconformably on the Sespe and Vaqueros Formations and is overlain by both the El Modeno Volcanics and the Puente Formation. This report follows the usage of English.

North of Santiago Creek, the Topanga Formation is exposed in a continuous band along the south side of Burruel Ridge eastward to Gypsum Canyon. An isolated exposure is present north of the Santa Ana River near the northeast corner of the map area. Southwest of Santiago Creek, the formation crops out discontinuously from the vicinity of El Modeno southeastward along the crest of Loma Ridge to the southeast corner of the map area, where it continues into the area mapped by Vedder and others (1957). The Topanga Formation is known to be present in the subsurface section throughout the lowland area north of Orange, although only a few deep wells have drilled completely through it. Wells southeast of Orange pass directly from rocks younger than the Topanga Formation into the undifferentiated Sespe and Vaqueros Formations; the contact is an erosional unconformity (Yerkes and others, 1965 , fig. 9). In the lowland area south and east of Santa Ana only two wells, the Red Star Oil Co. well, Ward Associates No. 1, and the Hoyt S. Gale well, Irvine No. 1, drilled into the Topanga Formation. These occurrences probably represent a northward extension of the $1,800 \cdot \mathrm{m}$-thick section in the northwestern part of the San Joaquin Hills (Vedder and others, 1957; Vedder, 1975).

$$
\text { STRATIGRAPHY AND LITHOLOGY }
$$

BASAI. CONGIOMLRATE

The base of the Topanga Formation is generally fairly well exposed and easily recognized throughout the map area. The undifferentiated Sespe and Vaqueros Formations, which everywhere underlie the Topanga Formation, consist of friable, easily eroded varicolored sandstone and conglomerate of marine and nonmarine origin. The basal part of the Topanga Formation consists of tan to gray conglomerate and sandy conglomerate that ranges in thickness from 2 to more than $9 \mathrm{~m}$. In contrast to the underlying weaker units, it is well cemented and resistant to erosion. Throughout the area, marine mollusks, including large pectinids and oysters, are common in this basal conglomerate; bones of marine mammals occur locally. This basal conglomerate is prominently exposed in the area north of Santiago Creek where the undifferentiated Sespe and Vaqueros consists almost entirely of nonmarine red beds. The contact is less evident south of Santiago Creek, where the base is less conglomeratic, and the upper part of the underlying sequence contains fossil beds. There is no evidence of an angular unconformity at the base of the Topanga Formation. In some areas the contact surface is slightly irregular and has a relief of several centimeters; in some places the basal conglomerate contains clasts of sandstone that seem to have been derived from the undifferentiated Sespe and Vaqueros.

$$
\text { SANDSTONEAND CONGIOMHRATL SANDSTONE }
$$

Above the basal conglomerate the Topanga Formation consists chiefly of resistant beds of light-tan to gray, medium- to coarse-grained, poorly sorted feldspathic sandstone that commonly contain crinkly flakes of greenish-black biotite and minor amounts of muscovite. Individual beds range in thickness from 0.3 to $3 \mathrm{~m}$. The less-resistant zones between the resistant beds are composed of finer grained poorly bedded sandstone and silty sandstone. Marine mollusks are generally common in these strata, and some dip slopes are strewn with shark teeth and fragments of whale bone.

Between the heads of Weir Canyon and Gypsum Can. yon, where the Topanga Formation is thickest, the lower and middle parts contain beds a meter or so thick of soft greenish-gray and reddish-brown sandstone and silty sandstone similar to that in the underlying undifferentiated Sespe and Vaqueros Formations (fig. 18). This rock type was not seen elsewhere. In this area many conglomeratic strata in the upper part of the formation contain cobbles and boulders of distinctive tourmaline-bearing crystalline rock. A similar rock is 
exposed in the basement complex near Sierra Peak in the map area and in the area southeast of Corona outside the map area, suggesting an eastern source for at least part of the sediments.

Two or more thin beds of white vitric tuff 1.5 to $3 \mathrm{~m}$ thick are interbedded in sandstone east of El Modeno. These tuffs, one about $45 \mathrm{~m}$ below the top of the Topanga Formation and another about $100 \mathrm{~m}$ above the base, have been described by Yerkes (1957, p. $316-317)$. Fish scales and molds of mollusks are present in the tuff, indicating deposition in water. Together with some fragmental volcanic rocks penetrated only in the Hoyt S. Gale well, Irvine No. 1, in the southwest corner of the area, these tuffs indicate the earliest Tertiary volcanic activity in the Santa Ana Mountains.

In the eastern part of the El Modeno area just south of Irvine Park Drive, a bed of creamy white organic siltstone a meter or so thick is the uppermost unit in the Topanga Formation. This siltstone has not been recognized elsewhere.

The southwesternmost exposures of the Topanga Formation are at Red Hill, east of Tustin. This hill, surrounded by Quaternary deposits, consists of thoroughly fractured sandstone that appears to be clayey, altered, and somewhat tuffaceous. Fairbanks (1893, p. 118) reported the presence of mercury in thin veins of barite that cut the sandstone. When visited in 1951, no evidence of mercury or barite could be found. Fairbanks (1893, p. 118) believed that the emplacement of the mercury was associated with the volcanic rocks of middle Miocene age (El Modeno Volcanics) that crop out a short distance to the north.

The thickest section of the Topanga Formation within the map area is at the east end of Burruel Ridge, between the heads of Gypsum and Weir Canyons. A section $689 \mathrm{~m}$ thick was measured there of fossiliferous white to $\tan$ to reddish-brown sandstone, pebbly to coarsely conglomeratic in many beds, especially near the top. Quartz is the principal mineral; feldspar is abundant and biotite fairly common. On the south side of Burruel Ridge, $3 \mathrm{~km}$ southwest, the formation is 120 $\mathrm{m}$ thick. Farther south, a measured section in the west corner of Irvine Block 69, southwest of Irvine Lake, is $61 \mathrm{~m}$ thick, probably in part because of postdepositional erosion before deposition of upper Miocene strata. This section is composed of interbedded sandstone and siltstone that contains abundant fossils.

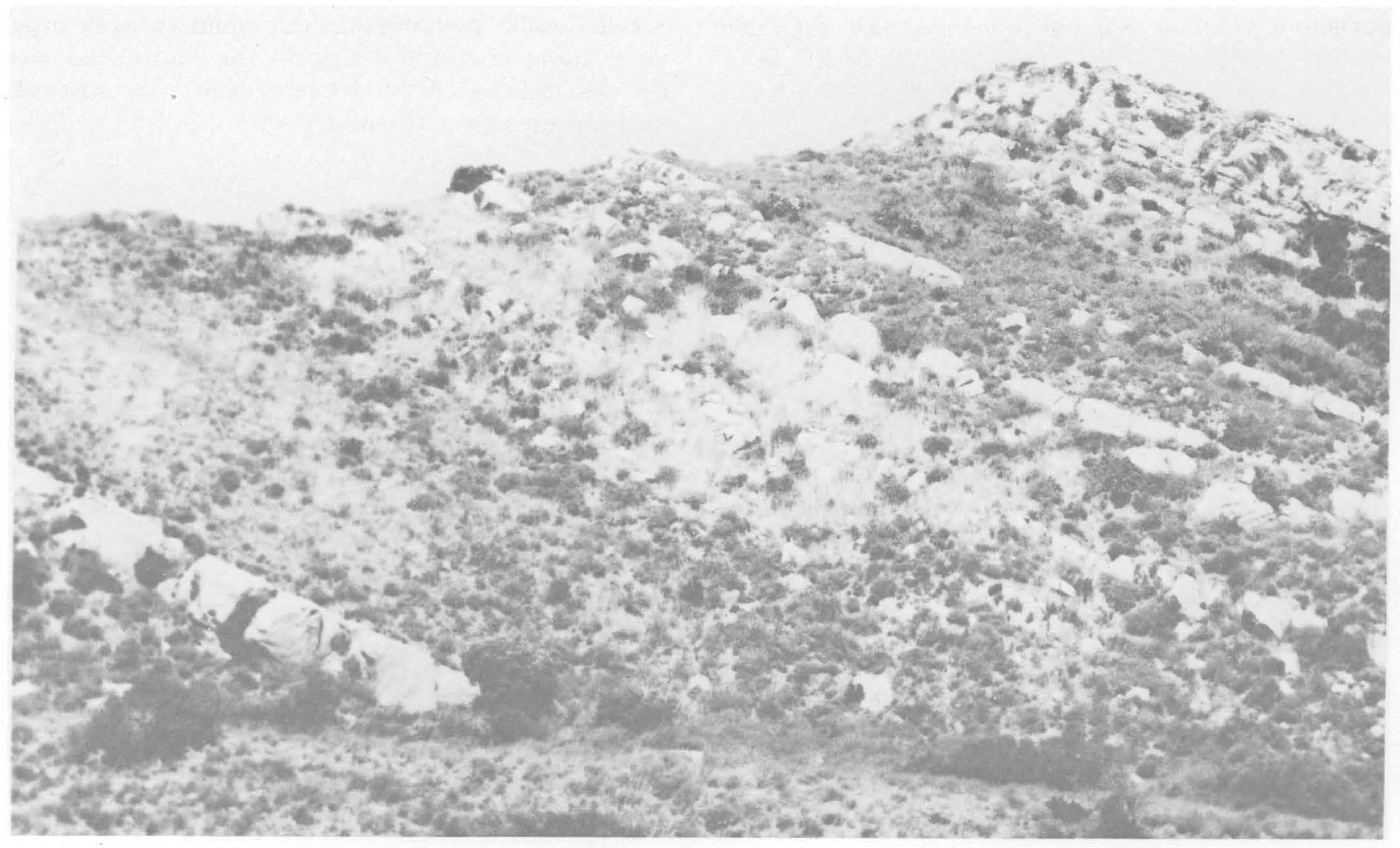

FIGURE 18.- Basal beds of the Topanga Formation. The beds are massive sandstone and less resistant variegated silty sandstone. View north from road near head of Gypsum Canyon at junction with road down Weir Canyon. Vertical dimension of the Topanga shown about $20 \mathrm{~m}$. 


\section{UPPER CONTACT}

The contact between the Topanga Formation and the overlying units is everywhere well defined. In areas where the formation is overlain by the El Modeno Volcanics there is no measurable angular discordance between the two formations. The volcanic rocks, however, probably rest on different parts of the Topanga sequence in different places, and the contact represents a surface of erosion. Where the Topanga Formation is overlain by the Puente Formation, the abrupt change from sandstone of the Topanga to siltstone of the Puente represents an unconformity, below which different amounts of Topanga have been eroded. The measured discordance between the Topanga and Puente Formations ranges from near zero to $30^{\circ}$ (in the Scully Hill area just north of the map boundary). In one area southwest of Irvine Lake, the entire Topanga Formation was eroded before the deposition of siltstone of the Puente.

\section{SUBSURFACE DISTRIBUTION}

In the subsurface section north and west of Burruel Ridge, the Topanga Formation is overlain by either the El Modeno Volcanics or the Puente Formation. Coarse-grained strata of the upper member of the Fernando Formation unconformably overlie the Topanga. Formation (and older units) in an area east of Orange ( structure sections $E-L$ and $L-Q$, pls. 2,3). Northwest of Orange and outside the map area, rocks correlated with the Topanga Formation have been penetrated in deep wells drilled along the Coyote Hills and the subparallel "Anaheim nose" to the south, where they occur beneath an unconformity at the base of the Puente Formation and are interbedded in some places with extrusive volcanic rocks (Yerkes, 1972, pl. 1).

Complete subsurface sections of the Topanga Forma. tion have been penetrated in the map area by only a few wells north and southwest of Burruel Ridge. Because the Topanga Formation is sparsely cored, its lithologic character must be surmised from electric-log characteristics and a few samples. An alternating sequence of gray, medium- to coarse-grained sandstone interbedded with gray siltstone and sandy siltstone predominates in the wells. Conglomerate beds occur sporadically throughout the section and are increas. ingly abundant to the north and east. Dark-colored siltsone and hard mudstone are important constituents in the wells west and northwest of the map area. Although adequate control is sparse, the Topanga, penetrated by wells, seems to be similar to that in the out. crop sections.

\section{AGEAND CORRELATION}

Fossil mollusks are locally abundant in the Topanga Formation and occur throughout the formation. Collec- tions from outcrops and the McKee Oil Co. well, Kokx Comm. No. 8-1 (F160), have been studied, and the species are included in the section "List of Megafos. sils." Common species include Turritella ocoyana, T. cf. $T$. ocoyana topangensis, T. temblorensis, Leptopecten andersoni, Chione temblorensis, Crassostrea cf. titan subtitan, and Vertipecten nevadanus. The molluscan faunas are typical of provincial middle Miocene assemblages throughout southern California.

Foraminifers are not abundant in the Topanga Formation of the map area. Three outcrop collections were taken from sandy siltstone near the base of the formation east of Cerro Villa Heights and in the El Modeno area. A core sample (locality $\mathrm{m} 182$ ) from about $410 \mathrm{~m}$ above the base of the Topanga Formation in the McKee Oil Co. well, Kokx Comm. No. 8-1, also contains a fairly rich foraminiferal fauna. These faunas were described by Smith (1960, p. 466 and table 3), who listed 11 species that have been questionably assigned to Kleinpell's (1938) Relizian Stage.

The Topanga Formation of the Santa Ana Mountains does not contain as thick or varied a lithologic sequence as is present on the San Joaquin Hills to the south, where it is divided into three named members (Vedder and others, 1957), or in the Santa Monica Mountains to the northwest where it was first defined by Kew (1932, p. 416-417). The dominant rock in all these areas is sandstone, and the molluscan and foraminiferal faunas are so similar that correlation between the areas is well established.

\section{EL MODENO VOLCANICS}

The name El Modeno Volcanics was proposed by Schoellhamer and others (1954) for a sequence of extrusive igneous rocks and minor interbedded sedimentary rocks exposed locally in the Santa Ana Mountains; they rest on a surface eroded into the Topanga Formation of provincial middle Miocene age and are unconformably overlain by the Puente Formation of provincial late Miocene age and locally by even younger strata. The El Modeno Volcanics is divisible into three parts in the type area $2 \mathrm{~km}$ east of El Modeno. They are, in ascending order, basalt flows; palagonite tuff and tuff-breccia; and andesite flows and flow breccia. All the parts are probably present in the complexly faulted area between the Peters Canyon Reservoir and Irvine Park, but it was not practicable to differentiate them on the geologic map. The El Modeno is present locally in the subsurface west of the outcrop area. The following summary is based on a detailed study made by Yerkes (1957).

The main outcrop area of the El Modeno Volcanics is in the low hills immediately east of the town of El Modeno. Isolated remnants crop out along the south side of 
Burruel Ridge and southeast of Cerro Villa Heights. In the subsurface, the El Modeno is present in wells along the west margin of the area from the Union Oil Co. well, Chapman No. 29, on the north to the Trustees Development Association well, No. 1, on the south (structure sections $A \cdot H$ and $M-F$, pl. 2). The fragmental volcanic rocks present in the Hoyt S. Gale well, Irvine No. 1 , in the southwest corner of the area are believed to be an older volcanic unit interbedded with the Topanga Formation. These rocks in the Gale well probably represent a northern extension of similar rocks exposed in the northern part of the San Joaquin Hills and in the subsurface section to the northwest of them (Vedder and others, 1957).

The maximum outcrop thickness of the El Modeno is about $230 \mathrm{~m}$. Three wells for which reliable data are available penetrated the complete volcanic sequence. These include the Union Oil Co. well, Chapman No. 29, just northwest of the map area, where about $100 \mathrm{~m}$ is present. Other wells in the area between Olive and Orange drilled into the volcanic rocks but did not penetrate through the sequence. None of the deep wells drilled into the Topanga Formation near the Olive oil field, in the Kraemer oil field, or along the north side of Burruel Ridge found volcanic rocks, although such rocks are widely distributed farther west in the Los Angeles basin (Eaton, 1958; Yerkes, 1972).

Submarine accumulation for at least a part of the: basalt flows of the El Modeno Volcanics is indicated by pillows with siltstone seams and by overlying fossiliferous marine siltstone. The bedded palagonitic material presumably was deposited in water deep enough to effect fairly uniform sorting over a relatively large area; winnowing by winds probably facilitated the sorting to, some extent. The angularity of the fragments shows: they are not reworked subaerial deposits. Large blocks . having distinct cooling cracks occur locally in the andesite flows and flow breccia, each block lying in a matrix of vesicular lava or palagonitic tuff. This is strong evidence of deposition of hot avalanche deposits characteristic of some volcanic explosions. Thus, the El Modeno Volcanics probably includes both submarine and subaerial deposits. No evidence was found to indicate a source for the deposits, although the uniformity of the sequence and distribution of individual lithologic units throughout the series indicates a source or sources that extruded large quantities of material over a wide area.

\section{ASSOCIATED IGNEOUS ROCKS}

A few andesite and basalt dikes too small to be shown on the geologic map intrude the El Modeno Volcanics, the Topanga Formation, and the Santiago Formation.

Steep or vertical vesicular and porphyritic andesite dikes intrude the Topanga Formation and the palagonite tuff, andesite flows, and flow breccia of the El।
Modeno Volcanics in the eastern part of sec. 23, T. 4 S., R. $9 \mathrm{~W}$. The dikes are generally less than $3 \mathrm{~m}$ thick and commonly less than $1.5 \mathrm{~m}$ thick; all are composed of porphyritic augite andesite identical with that of the andesite flows and flow breccia. The similarities in composition and field relations suggest that the dikes are nearly equivalent in age with the andesite flows and flow breccia.

Dense black basalt dikes cut the Topanga Formation in the area south of Panorama Heights, in the east part of sec. 23, T. 4 S., R. 9 W., and the Santiago Formation near the mouth of Weir Canyon. These dikes are petrographically similar and are rather finely porphyritic, having phenocrysts up to $0.7 \mathrm{~mm}$ in maximum diameter. These dikes are younger than the Topanga Formation; they may be contemporaneous with or younger than the El Modeno Volcanics.

Altered basalt is present in the Standard Oil Co. well, Zaiser-Brelje Community No. 1, between 1,325 and $1,355 \mathrm{~m}$ depth. This rock is believed to be intrusive along a fault that separated the Topanga Formation from the undifferentiated Sespe and Vaqueros Formations, and a second small dike or sill is completely enclosed by the undifferentiated Sespe and Vaqueros.

AGE AND CORRELATION

Fossils in sedimentary rocks of the El Modeno Volcanics and in the underlying and overlying formations permit dating of the El Modeno. The siltstone at the top of the basalt flows in the El Modeno area contains fish scales of probable middle Miocene or early late Miocene age (W. T. Rothwell, in Yerkes, 1957, p. 317). The claystone bed that overlies the basalt flows in the southeastern part of Burruel Ridge contains foraminifers (locality $\mathrm{m} 183$ ) that are assigned to the upper part of Kleinpell's (1938) Luisian Stage (Smith, 1960, p. 466 , table 3). The underlying Topanga Formation contains a large molluscan fauna of provincial middle Miocene age and poor foraminiferal faunas questionably assigned to Kleinpell's (1938) Relizian Stage (Smith, 1960, p. 466, table 3). The La Vida Member of the Puente Formation locally rests apparently conform. ably on the andesite flows and flow breccia of the El Modeno and contains foraminifers diagnostic of the lower part of Kleinpell's Mohnian Stage (Smith, 1960). The El Modeno Volcanics thus appears to be provincial middle Miocene in age. Eaton (1958) placed the entire El Modeno in the Luisian Stage (late middle Miocene) on the basis of regional stratigraphic relations.

Large volumes of andesitic and basaltic rocks were extruded throughout much of the Los Angeles basin during middle Miocene time. Lava flows and pyroclastic rocks are the dominant rock types, but dikes and sills of similar composition are common in some areas. Outcrop areas of volcanic rocks that correlate in part 
with the El Modeno Volcanics include the GlendoraPomona area (Shelton, 1955), the Santa Monica Mountains (Hoots, 1931; Durrell, 1954), the Palos Verdes Hills (Woodring and others, 1946), and the San Joaquin Hills (Vedder and others, 1957; Vedder, 1975). Volcanic rocks similar to those found in these outcrops extend deeper into the Los Angeles basin and are present beneath the Inglewood and Dominguez oil fields and on the north flank of the Long Beach oil field; they are also present in the subsurface in the eastern part of the Los Angeles basin, west of the outcrop area of the El Modeno Volcanics. The inferred subsurface extent of upper middle Miocene volcanic rocks is delineated by Yerkes and others (1965, fig.9).

\section{MIDDLE AND UPPER MIOCENE}

\section{MONTEREY SHALE}

The name Monterey Formation or Monterey Shale has been used in the Coast Ranges of California for a lithologically distinct sequence of diatomaceous and siliceous shale and siltstone of Miocene age, first described by Blake (1856, p. 328-331) near the town of Monterey. The usage of the name Monterey has a long and complex history that has been reviewed by Woodring and others (1940, p. 122-123). The stratigraphy, lithology, and origin of the siliceous rocks in the Monterey Formation throughout California have been discussed in detail by Bramlette (1946).

Siliceous, diatomaceous, and organic shale and siltstone of provincial middle and late Miocene age crop out sparingly and occur discontinuously along the seaward side of Los Angeles basin from the Palos Verdes Hills southeast to the vicinity of San Clemente. These rocks have been called the Monterey Shale in the Palos Verdes Hills (Woodring and others 1946, p. 13-40), and this usage has been extended southeastward along the coast to include rocks of similar lithology in the San Joaquin Hills-San Juan Capistrano area (Vedder and others, 1957; Vedder, 1975). To the north in the Santa Ana Mountains and the Puente Hills, part of the upper Miocene Puente Formation is similar lithologically to the Monterey, but it also contains thick and widespread members composed almost entirely of coarse clastic material. The finer grained members of the Puente Formation are also more clastic than their counterparts in the Monterey. Two depositional environments, now represented by dissimilar lithologic facies, justify the division of these middle and upper Miocene strata in the map area into two formations, the Monterey Shale and the Puente Formation. The rocks here mapped as Monterey Shale represent the northernmost extension of the Monterey facies of the San Joaquin Hills-San Juan Capistrano area. To the south in the Aliso and Oso Creeks area (sec. 17, T. 6 S., R. 7 W.) the lower part of the Puente Formation grades laterally southwestward into the Monterey Shale, and the contact is arbitrarily placed at the Cristianitos fault and in the alluviated valley of Oso Creek (Vedder and others, 1957). Coarser clastic rocks like those of the Puente occur above the Topanga Formation in the subsurface section northwest of the San Joaquin Hills (Vedder, 1975).

Outcrops of the Monterey Shale are restricted to the extreme south edge of the map area in a small upfaulted block between Lambert Reservoir and Agua Chinon Wash. Its westward extension in the subsurface is terminated by the north-trending fault in Bee Canyon (structure section $T \cdot X, \mathrm{pl} .3$ ). Exposures of the Monterey Shale are limited, and the gently rolling hills developed on it are covered by a thin layer of gray to black clayey soil that supports a sparse growth of low brush, grass, and wild mustard on the steeper slopes and that merges in the lower areas adjacent to the major stream courses with thicker alluvial deposits.

\section{STRATIGRAPHY AND LITHOLOGY}

The base of the Monterey Shale is not exposed in the map area. Directly to the south, between Agua Chinon Wash and Serrano Creek, it rests on the Topanga Formation (Vedder and others, 1957). Presumably this contact is an unconformity, but its exact nature has not been determined because of poor exposures. Farther south in the San Juan Capistrano-San Joaquin Hills area, the Monterey Shale is locally uncomformable on and intertongues with the San Onofre Breccia and suc. cessively overlaps the Topanga, Vaqueros, and Sespe Formations.

The Monterey Shale in the map area consists of a poorly exposed sequence of interbedded siltstone and sandstone. The siltstone is white, gray and pale chocolate brown, soft, punky, and generally thinly laminated. It contains small flakes of golden-brown mica and locally diatom fragments; foraminifers and fish remains are abundant. The interbedded feldspathic sandstone is light tan, fine to coarse grained, locally graded, and ranges in thickness from thin laminae to beds about $1 \mathrm{~m}$ thick.

Sandstone and conglomerate of the Pliocene Niguel Formation probably unconformably overlie the Monterey Shale in the area between Lambert Reservoir and Agua Chinon Wash, although the contact between the two is not exposed. In the San Juan Capistrano-San Joaquin Hills area to the south, the Monterey Shale is unconformably overlain by the Oso Member of the Capistrano Formation and the Niguel Formation (Vedder and others, 1957).

Judging by the stratigraphy a short distance to the south (Vedder, 1975), the Monterey Shale in the map area is at least $75 \mathrm{~m}$ thick. 
AGE AND CORRELATION

Foraminifers were collected from two localities in the Monterey Shale on the east side of the Lambert Reservoir spillway. The faunas, from localities $\mathrm{m} 184$ and m185, included in the section "List of Microfossils,"have been identified by Smith (1960, p. 470, table 4) and questionably assigned to Kleinpell's (1938) Luisian Stage. These and other foraminiferal faunas have been discussed in detail by Smith (1960) and Ingle (1972), who concluded that the Monterey Shale in the San Juan Capistrano-San Joaquin Hills area is provincial middle and late Miocene in age (Luisian and lower Mohnian Stages).

Where there is lateral gradation of the Monterey Shale into the lower part of the Puente Formation, the strata are not known to be older than late Miocene. As the Monterey Shale in areas to the south includes strata of early middle Miocene age, deposition of the fine-grained organic and siliceous sediments started earlier there and did not begin farther north until late Miocene time.

\section{UPPER MIOCENE PUENTE FORMATION}

The Puente Formation was named by Eldridge and Arnold (1907), p. 103) for exposures in the Puente Hills. They included in it all Miocene siltstone and sandstone in the area between the Santa Ana River and the vicinity of Cahuenga Pass in the eastern part of the Santa Monica Mountains. They divided it.into three units: the lower Puente shale, the Puente sandstone, and the upper Puente shale.

English (1926) used the name Puente Formation for most of the rocks exposed in the Puente Hills north of the Whittier fault and for the rocks of late Miocene age exposed along the north slope of Burruel Ridge south of the Santa Ana River. He divided the Puente Formation into three main units: a lower shale, a middle sandstone, and an upper member that included a succession of alternating shale, sandstone, and conglomerate.

Daviess and Woodford (1949) divided the Puente Formation in the northwestern Puente Hills into four members: a lower siltstone member; a sandstone member; an upper siltstone member; and the Sycamore Canyon Member, which consists of conglomerate and interbedded sandstone and siltstone. Locally the Sycamore Canyon Member grades laterally into the upper siltstone member.

Richmond (1952) mapped the Puente Formation in the western part of the Burruel Ridge area and modified English's (1926) usage to make it consistent with that proposed by Daviess and Woodford (1949).

Later detailed mapping by the U. S. Geological Sur- vey in the Puente Hills and the Santa Ana Mountains emphasized the need for formal member names for all four main units of the Puente Formation, and these were proposed by Schoellhamer and others (1954). in a preliminary report on the Santa Ana Mountains. In ascending order these are the La Vida Member, the Soquel Member, the Yorba Member, and the Sycamore Canyon Member. This usage, which has been followed by Durham and Yerkes (1964) and Yerkes (1972) in the Puente Hills to the north and northwest, is continued in this report.

In areas on and near Burruel Ridge where the lenslike Soquel Member is locally absent, it is impracticable to differentiate the La Vida and Yorba Members, and these units are shown on the geologic map as undifferentiated La Vida and Yorba Members.

LA VIDA MEMBER

The La Vida Member of the Puente Formation is present along the south slopes of Burruel Ridge and in small isolated patches in the hills south and east of El Modeno. Extensive, discontinuous exposures are found along the higher parts of Loma Ridge from the Peters Canyon Reservoir southeast to the head of Limestone Canyon. Along the southern edge of the map area, the westernmost exposure is between Bee Canyon and Round Canyon. East of Agua Chinon Wash, it forms a continuous belt that extends to the southeast corner of the map area, where it grades laterally into the Monterey Shale near the head of Oso Creek (Vedder and others, 1957).

Exposures of the La Vida Member are generally poor except for those found on steep slopes, in the bottoms of flushed-out gullies, and in excavations. Smooth, rounded hills underlain by the member are covered with a thick mantle of gray to black clayey organic soil that contains occasional angular fragments and blocks of limy white siltstone. The soil supports a lush growth of grass and wild mustard during rainy seasons. Brush and cactus are rare on the La Vida but grow profusely on sandstone of the overlying Soquel Member and the underlying Topanga Formation. In areas of poor exposures this change in vegetation is useful for defining contacts.

The exposed thickness of the La Vida Member is variable; no detailed sections have been measured. In the southeastern part of Burruel Ridge, structure section $G \cdot J$ (pl. 2) suggests a thickness of about $230 \mathrm{~m}$, a maximum for this area. South of Irvine Lake, structure section $R \cdot S$ ( pl. 3) indicates a thickness of about 600 $\mathrm{m}$, although this section may be complicated by undetected faults, which could not be traced in the La Vida. Structure section $A \cdot K$ ( pl. 2), only $1 \mathrm{~km}$ to the east, indicates a thickness of only $60 \mathrm{~m}$. In the southeastern 
corner of the map area, a sketch section in the first canyon east of structure section $T \cdot X(\mathrm{pl} .3)$ indicates a thickness of about $105 \mathrm{~m}$, probably representative for this area.

\section{STRATIGRAPHY AND LITHOLOGY}

\section{Basal contact and associated rocks}

A regional unconformity separates the La Vida Member of the Puente Formation from underlying formations. On the south side of Burruel Ridge, the La Vida rests on bevelled strata of the Topanga Formation and on basalt that is probably in the oldest part of the El Modeno Volcanics. East of El Modeno, the La Vida rests on the andesite flows and flow breccia, which is the youngest part of the El Modeno Volcanics. South of Irvine Lake and west of Limestone Canyon, the La Vida rests on fault-separated blocks of the undifferentiated Sespe and Vaqueros Formations; different stratigraphic horizons are exposed beneath the unconformity in each block, indicating that the fault displacements occurred before the La Vida formed. Southeast from Irvine Block 117 to the southeast corner of the map area, the Topanga Formation is present beneath the unconformity, with the exception of a short strip between Bee and Round Canyons, where the La Vida rests on the undifferentiated Sespe and Vaqueros (fig. 19).

The lithologic contrast between the La Vida Member and the underlying units is always sharp. On Burruel Ridge the base of the La Vida is marked by a thin and discontinuous breccia bed composed of blocks and fragments of limy siltstone and other rocks in a matrix of coarse-grained, poorly sorted sandstone. Elsewhere siltstone of the La Vida Member rests directly on older formations and contains little or no interbedded sandstone. On Loma Ridge near the head of Little Joaquin Valley, sandstone lenses near the base are indicated on the geologic map, as are other stratigraphically higher sandstone, conglomerate, and breccia beds. On Loma Ridge the basal unit consists of about $10 \mathrm{~m}$ of bone-white, coarse-grained gritty feldspathic sandstone that contains many gray to black subangular to subrounded clasts of siltstone and sandstone similar to rocks in the Bedford Canyon Formation; other rock types are present in less abundance. A thin discontinuous bed of light-yellow to tan sandy tuff or volcanic sandstone is locally present at the base of the La Vida Member in the El Modeno area and between Peters Canyon Reservoir and Irvine Lake. A similar tuff is interbedded in the basal part of the La Vida Member above the easternmost outcrops of the El Modeno Volcanics on Burruel Ridge. This tuffaceous unit has been described in detail by Yerkes (1957, p. 322-323). Most of the material in the tuff is believed to be derived from the El Modeno Volcanics. The presence of different rock fragments and detrital quartz suggests re- working and lateral gradation into less tuffaceous siltstone and sandstone.

\section{Siltstone and sandstone}

Siltstone is the dominant rock type in the La Vida Member. Minor amounts of fine- to coarse-grained feldspathic sandstone are interbedded. Fresh exposures of the siltstone are dark gray to black: as weathering progresses, the color gradually changes to chocolate brown, pinkish gray, and ultimately almost to white. The dark color of unweathered rock is probably caused by finely disseminated organic material. Fish bones and scales, abundant foraminifers, and cream-colored phosphatic nodules as much as $1 \mathrm{~cm}$ in diameter are present locally. Bedding in the siltstone varies from massive and indistinct to well laminated. Most of the siltstone is soft and easily weathered; in some areas it is hard and brittle, and beds $1 \mathrm{~m}$ or so thick protrude from the surrounding rock. These harder units appear to be more siliceous and in many places consist of porcellaneous siltstone or shale. The sandstones are repetitiously interbedded in the siltstone and range in thickness from less than a centimeter to a meter or more. They are feldspathic, contain minor amounts of biotite, range from fine- to coarse-grained, and are gray when fresh but weather to a light tan or buff. Lenticular beds of hard calcareous siltstone that pinch and swell along bedding planes and concretionary zones up to $1.5 \mathrm{~m}$ thick make up a minor but conspicuous part of the La Vida. Freshly broken surfaces of the siltstone are gray to brownish-yellow, and exposed surfaces are creamy white. Weathered surfaces are commonly studded with recrystallized tests of foraminifers. Chips and blocks of this hard white siltstone are common in the soil derived from the siltstone beds.

Throughout the map area the upper part of the La Vida Member contains more interbedded sandstone than the lower part; the contact with sandstone of the overlying Soquel Member is in most places gradational. On southeastern Burruel Ridge near Weir Canyon, the Soquel transgresses the uppermost La Vida. On Loma Ridge the Soquel cuts more deeply; between the heads of Rattlesnake and Limestone Canyons, it rests on the undifferentiated Sespe and Vaqueros Formations for a distance of about $300 \mathrm{~m}$.

On the south side of Burruel Ridge a breccia bed about $25 \mathrm{~m}$ thick is present within the La Vida Member. It is composed of angular blocks of limy siltstone as much as $1.5 \mathrm{~m}$ in maximum dimension enclosed in a matrix of coarse-grained, calcareous sandstone. This intraformational unit rests unconformably on the bevelled siltstone of the La Vida, progressively truncating older beds of the La Vida toward the east. Coarsegrained gritty feldspathic sandstone and conglomerate 
occur in the La Vida in the area between Peters Canyon reservoir and Irvine Lake. Presumably these lenses of coarse clastic material, enclosed in a predominantly silty section, originated either from local tectonic activity or penecontemporaneous erosion and deposition and represent local unconformities within the member.

Several thin beds of white vitric tuff are present in the La Vida Member in the southern part of the area east of Agua Chinon Wash. These tuff beds, only a meter or so thick, resist weathering poorly and are exposed only in road cuts. They are fine grained, soft, massive, structureless, and vitroclastic. Most samples contain some glass shards and pipes; other samples are composed entirely of glass fragments. The glass is clear, fresh, and isotropic and has an index of refrac- tion between $1.4987 \pm 0.0003$ and $1.5021 \pm 0.0003$. Three thin sections contain plagioclase (about $\mathrm{An}_{37}$ ), and a fourth sample is composed entirely of glass fragments. Tuff of similar appearance is present in both the La Vida Member and the Monterey Shale in the San Juan Capistrano area to the south.

\section{SUBSURFACE DISTRIBUTION}

The La Vida Member has been differentiated in the subsurface only in those areas where it is overlain by the sandstone of the Soquel Member. It is recognizable everywhere in the subsurface north of Burruel Ridge; its southwestern limit within the map area is marked by the line of pinchout (fig. 20) of the Soquel Member,

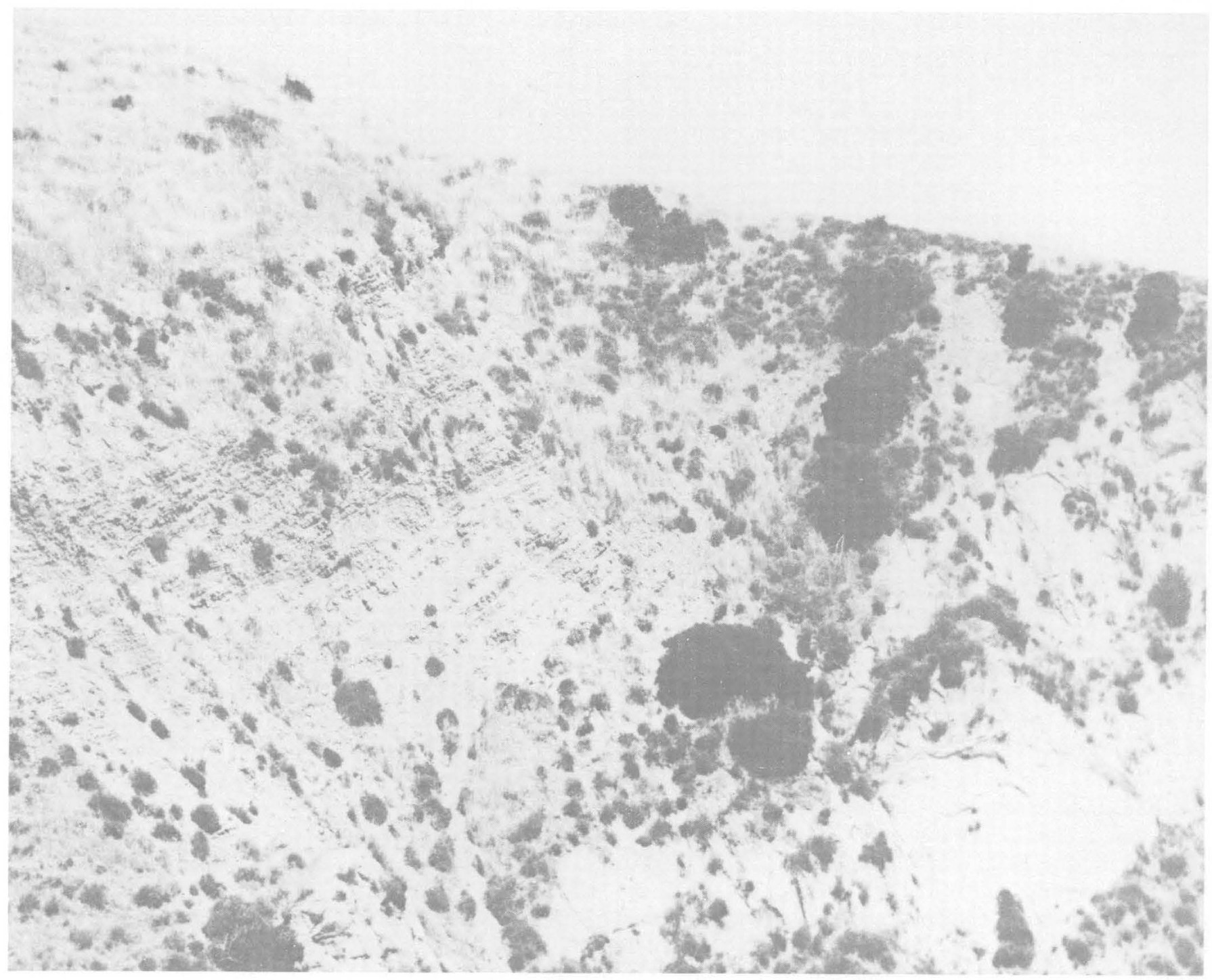

FIGURE 19.- Unconformity between the overlying La Vida Member of the Puente Formation and the undifferentiated Sespe and Vaqueros Formations. South-facing cliff in south quarter corner of Irvine Block 80, south of Irvine Lake. The La Vida Member dips more steeply (north or left) than the undifferentiated Sespe and Vaqueros. View east. 


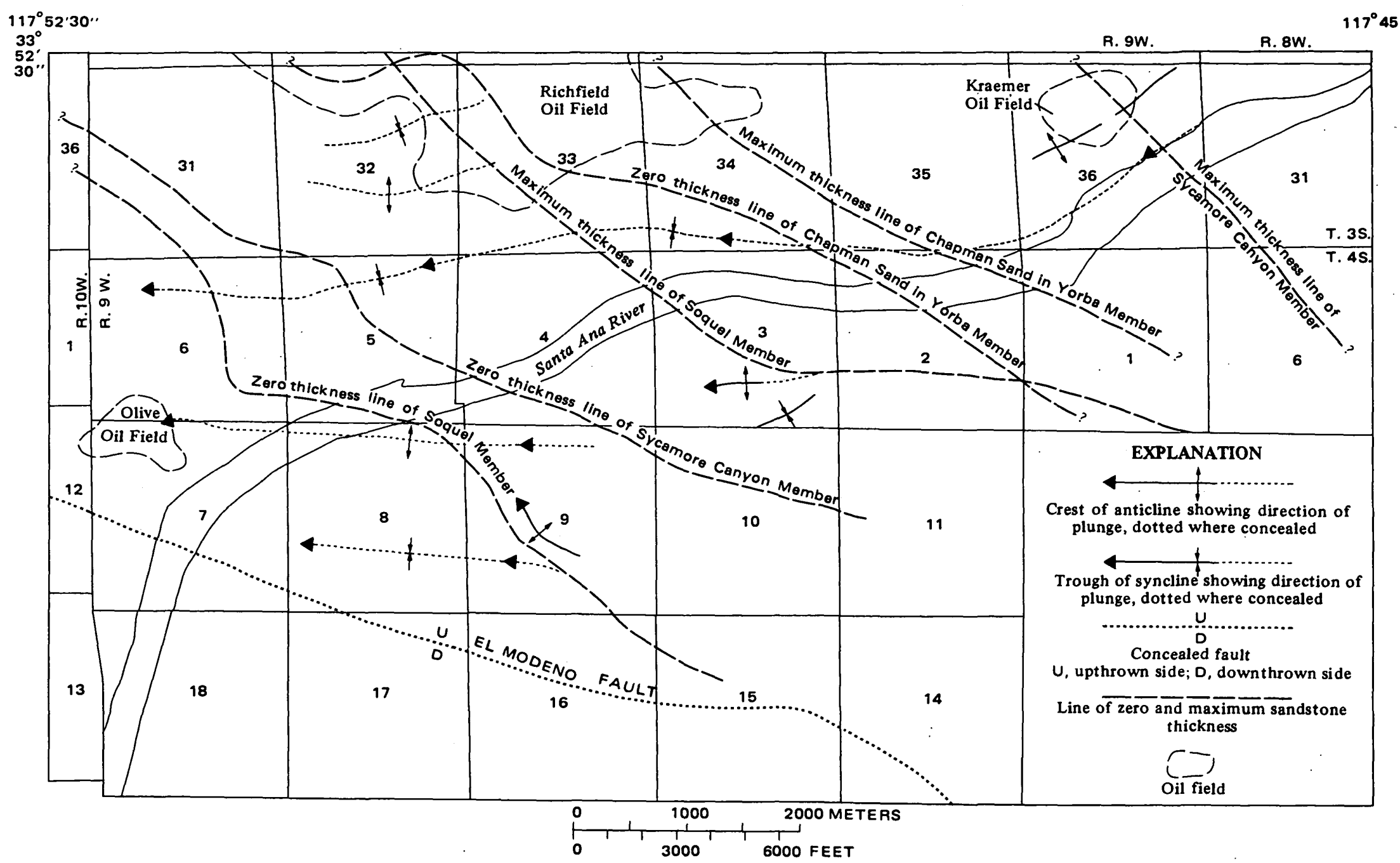

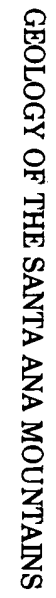

FIGURE 20.- Schematic map of the northern part of the Orange quadrangle showing relations between fold axes and lines of zero and maximum thickness of sandstone in the Soquel, Yorba and Sycamore Canyon Members of the Puente Formation. 
which trends northwest from the western part of Burruel Ridge to the northwestern corner of the map area (structure sections $B \cdot N, A-C$, and $E-L, \mathrm{pl} .2$ ).

In the subsurface section north of Burruel Ridge, the La Vida Member of the Puente Formation rests unconformably on both the El Modeno Volcanics and the Topanga Formation. The same relations are exposed along the south side of the ridge. The El Modeno Volcanics is present beneath the La Vida Member in the Union Oil Co. well, Chapman No. 29, and the Texas Oil Co. well, Bennet No. 1, the only wells north of the Santa Ana River to penetrate volcanic rocks similar to the El Modeno. Other wells pass directly from the La Vida Member into sandstone and siltstone of the Topanga Formation, and the El Modeno is absent probably because of erosion.

The base of the La Vida Member in subsurface is placed at the base of a dominantly siltstone sequence, a contact easily recognized on electric logs. The few core samples available indicate that the member consists of hard, dark-gray to black siltstone and silty shale. Locally phosphatic nodules, fish scales, and small pyrite crystals are present. Bedding varies from paper-thin laminations containing crushed foraminifers on freshly broken surfaces to massive beds a meter or so thick. The bedding commonly is accentuated by laminae and beds of fine- coarse-grained gray feldspathic sandstone. The interbedded sandstone, which can reach a thickness of $3 \mathrm{~m}$ or more, is scattered throughout the member but is most numerous in its upper part. The contact between the La Vida Member and the overlying Soquel Member is placed at the base of a massive sandstone bed, or the lowest of a series where present. Where the massive sandstone of the overlying Soquel Member is missing, the La Vida and Yorba Members cannot be differentiated (except by means of detailed micropaleontology).

The thickness of the La Vida Member varies only slightly throughout its subsurface extent. About $340 \mathrm{~m}$ of section is present in the Union Oil Co. well, Chapman No. 29, in the vicinity of the Richfield oil field, and about the same thickness of beds is present in the Shell Oil Co. well, Travis No. $1,8 \mathrm{~km}$ to the east (structure section $A-H$, pl. 2). About $150 \mathrm{~m}$ is present in the Texas Oil Co. well, Carrillo Ranch (NCT-1) No. 1, $2 \mathrm{~km}$ farther east. Thicknesses range from 120 to $160 \mathrm{~m}$ along the north side of Burruel Ridge, and about $100 \mathrm{~m}$ of the La Vida is present in the A. A. Carrey well, Bixby-Nohl No. 1, near the southwestern limit of the northern area in which it is differentiated.

$$
\text { AGE AND CORREIATION }
$$

Megafossils were collected from one locality (F168) south of Irvine Lake in a thin sandstone and conglomerate bed near the base of the La Vida Member. The only identifiable species is Leptopecten cf. L. discus (Conrad), which is of middle(?) and late Miocene pro. vincial age in California.

Foraminifers collected from widely distributed localities in the member have been identified by Smith (1960, p. 468-470, tables 3 and 4) and are cited in the "List of Microfossils." These assemblages belong to the lower part of Kleinpell's (1938) Mohnian Stage.

Although foraminifers are locally abundant in well cores of the La Vida Member, no systematic attempt was made to collect and study them. No evidence was found to indicate that the age of the subsurface section differs from that of the outcrop section, and it is provisionally assigned to the lower part of Kleinpell's Mohnian Stage.

\section{SOQUEL MEMBER}

The Soquel Member of the Puente Formation is exposed on the south side of Burruel Ridge from the vicinity of Cerro Villa Heights eastward to Weir Canyon. It was not recognized northeast or west of this outcrop area, where the finer grained, probably in part contemporaneous rocks are assigned to the undifferen. tiated La Vida and Yorba Members. Patches of the Soquel are present along the crest of Loma Ridge between Peters Canyon reservoir and the head of Limestone Canyon, and a separate continuous belt is ex. posed on the south boundary of the map area. The rocky ridges and brushy or tree-covered slopes underlain by the Soquel are everywhere in sharp contrast to the grassy slopes of the underlying La Vida and the overlying Yorba Members.

STRATIGRAPHY AND LITHOLOGY

In the Burruel Ridge area the contact between the Soquel Member and the underlying La Vida Member is gradational, and the base of the Soquel is placed at the base of the dominantly sandstone section. At its southeasternmost exposure on Burruel Ridge near Weir Canyon, the base of the member appears to transgress eastward onto successively older strata of the La Vida Member in a way suggesting a local expression of a regional unconformity.

Southwest of Santiago Creek the map relations indicate that the base of the Soquel Member is an unconformity. At the west end of Loma Ridge the Soquel rests directly on a tuff at or near the base of the La Vida Member. Between the head of Rattlesnake and Limestone Canyons the Soquel member rests directly on strata of the undifferentiated Sespe and Vaqueros Formations for a distance of about $300 \mathrm{~m}$.

Throughout the map area, medium- to coarsegrained feldspathic sandstone containing biotite is characteristic of the Soquel Member. Interbedded thin gray siltstone, conglomeratic sandstone, conglomerate, 
and breccia are local minor variants. At the west end of Burruel Ridge the member consists of interbedded fine- to coarse-grained feldspathic sandstone and minor amounts of gray siltstone. Weathered outcrops are brownish yellow to tan, and fresh exposures are light gray. In this area bedding is well developed in the sandstone and ranges from thin laminae to beds as much as $3 \mathrm{~m}$ thick. The member is increasingly coarser grained eastward and is coarsest at the head of Walnut Canyon, where it also has its maximum outcrop thickness. There it consists of coarse-grained to gritty sandstone, conglomeratic sandstone, and lenticular conglomerate beds that locally contain blocks of calcareous siltstone derived from either the La Vida Member or the Monterey Shale. Fine-grained sandstone, sandy siltstone, and siltstone are locally interbedded with these coarser clastic units. At its northeasternmost outcrop the Soquel Member consists of coarse micaceous sandstone and grit but lacks conglomerate, suggesting that grain size decreases slightly northeastward.

In the Loma Ridge area the Soquel Member is composed chiefly of massive, coarse-grained to gritty. poorly sorted feldspathic sandstone; weathered outcrops range from white to brownish yellow. Thin beds of medium- to fine-grained well-laminated micaceous sandstone and lenticular sandy conglomerate beds contain blocks as much as $1 \mathrm{~m}$ in maximum dimension of white, calcareous, foraminiferal siltstone, bored by pholads before erosion and redeposition.

Along the south side of Loma Ridge east of Bee Canyon the lithology of the Soquel Member is more varied, and the section is thicker than elsewhere south of Santiago Creek. The Soquel there consists of a sequence of interbedded sandstone, siltstone, and resistant conglomerate beds that extend for considerable distances along the strike. These beds contain a few clasts of glaucophane schist and other metamorphic rocks similar to those common in the San Onofre Breccia farther south. Their rarity in the Puente Formation suggests that they may have been derived from the local erosion of the San Onofre and transported northward during a second cycle.

A section of the Soquel measured on the ridge east of Agua Chinon Wash (Irvine Blocks 176 and 177) is about $470 \mathrm{~m}$ of sandstone, conglomerate, and siltstone between the underlying La Vida Member of the Puente Formation and the overlying Oso Member of the Capistrano Formation. The Soquel here is in alternating successions of tan to white sandstone and conglomerate in units 40 to $60 \mathrm{~m}$ thick, and chocolate-brown to gray siltstone in units 15 to $75 \mathrm{~m}$ thick; marine fish scales are present in the lowest siltstone. Boulders of granitic and metamorphic rocks are up to $45 \mathrm{~cm}$ in diameter.
The contact of the Soquel Member with the overlying Yorba Member is believed to be gradational in the Burruel Ridge area. Outcrops are poor, and neither unit contains marker beds sufficiently well exposed near the contact to establish the exact relationship. The top of the Soquel Member is marked by a change from sandstone and some interbedded siltstone to the dom. inantly siltstone sequence of the Yorba Member. The mapping south of Walnut Canyon suggests a southward transgression of the Yorba Member onto the Soquel Member, but lateral gradation is equally or more probable.

On the south side of Loma Ridge the Soquel Member and the overlying Oso Member of the Capistrano Formation are apparently conformable. In the area east of Agua Chinon Wash the top of the Soquel Member is placed at the top of the highest chocolate-brown siltstone. Between Bee Canyon and Round Canyon this siltstone is absent, and the top of the member is arbitrarily placed at the top of the highest evident conglomerate. The overlying white sandstone of the Oso Member is indistinguishable from that in the upper part of the Soquel Member, and the presence of welldefined conglomerate beds in the Soquel is its only distinctive feature in this part of the area.

On Burruel Ridge the Soquel Member is a large sandstone lens of variable thickness that grades westward into siltstone in the Cerro Villa Heights area (fig. 20 ). At the northeastern limit of the Puente Formation near the Santa Ana River, no sandstone is present between the base of the Puente Formation and the base of its Sycamore Canyon Member, indicating that the Soquel Member also grades northeastward into siltstone.

North of Cerro Villa Heights the geologic map suggests a thickness of about $150 \mathrm{~m}$ for the Soquel Member. It thickens irregularly eastward to the vicinity of Walnut Canyon, where a section about $490 \mathrm{~m}$ thick is exposed (structure section $G \cdot J, \mathrm{pl} .2$ ). The Aeco Corporation well, Nohl-Bixby No. 1 , drilled in Walnut Canyon, spudded in the upper part of the Soquel Member and penetrated its base at $485 \mathrm{~m}$ depth, verifying the outcrop thickness of about $490 \mathrm{~m}$. Along the crest of Loma Ridge, where the upper part of the Soquel Member has been removed by erosion, its maximum thickness is about $150 \mathrm{~m}$. East of Agua Chinon Wash the measured section is about $470 \mathrm{~m}$ thick.

\section{SUBSURFACE DISIRIBUTION}

The Soquel Member is easily recognized in the subsurface section north of Burruel Ridge. Its southwestern limit is marked by the pinchout line (fig. 20) that trends northwest from the westernmost outcrop of Soquel sandstone on Burruel Ridge toward the north- 
west corner of the map area (structure sections $B-N$, $A \cdot C$, and $E \cdot L, \mathrm{pl} .2$ ). In the southeastern part of the map area the subsurface extent of the member is not known. It is not present in any of the wells drilled west of the mouth of Bee Canyon.

Throughout its subsurface extent the base of the Soquel Member is a well-marked lithologic discontinuity that is as easily recognized on electric logs as it is in the outcrop. The basal part of the member consists of medium- to coarse-grained gray sandstone and minor amounts of interbedded siltstone.

Above its basal part the Soquel Member consists of gray, fine- to coarse-grained sandstone and pebbly sandstone that is generally poorly sorted and feldspathic and contains variable amounts of greenish-black to black biotite. Bedding in the sandstone ranges from thin laminae of fine-grained sandstone to massive sandstone beds many meters thick, Gray to almost black siltstone and sandy siltstone is interbedded in most places and ranges in thickness from discrete beds $6 \mathrm{~m}$ thick or more to thin laminae.

The contact between the Soquel Member and the overiying Yorba Member is gradational. In the Richfield oil field, northwest of the map area, the lowest producing sandstone is called the Kraemer zone (Gardiner, 1943, p. 357); the top of this zone is correlated with the top of the Soquel Member.

The thickness of the Soquel Member varies greatly throughout its subsurface extent in the map area. The thickest section is in the Union Oil Co. well, Chapman No. 29 , where about $890 \mathrm{~m}$ of the Soquel is present (fig. 20). Eastward along the north side of the Santa Ana River the member thins gradually to about $350 \mathrm{~m}$ in the Shell Oil Co. well, Travis No. 1, and about $170 \mathrm{~m}$ in the Texas Co. well, Carrillo Ranch (NCT-1) No. 1 ( structure section $A \cdot H$, pl. 2). It probably pinches out a short distance southeast of this well, as shown in structure section $H \cdot O$ (pl. 3). Numerous wells have penetrated the Soquel Member along the north slope of Burruel Ridge, and its thickness there is demonstrably quite variable. About $290 \mathrm{~m}$ of the Soquel was penetrated in the Santa Ana Canyon Oil Co. well, Crowthers No. 1 , about $490 \mathrm{~m}$ in the Rubicon Co. well, Wilcox No. 1 , about $400 \mathrm{~m}$ in the G. D. Murdock well, Howell No. 1 , and about $685 \mathrm{~m}$ in the Richfield Oil Corporation well, Peralta Hills No. 1 (structure section $B-N$, pl. 2). The member thins rapidly to the southwest and west from the Peralta Hills well. About $190 \mathrm{~m}$ is present in the Olive-Ventura Oil Corporation well, Bixby No. 1, and $80 \mathrm{~m}$ in the A. A. Carrey well, Bixby-Nohl No. 1. South of the Richfield oil field the Soquel thins from about $890 \mathrm{~m}$ in the Union Oil Co. well, Chapman No.
29 to about $580 \mathrm{~m}$ in the Texas Co. well, Bennet No. 1 (structure section $A \cdot C$, pl. 2), and to about $110 \mathrm{~m}$ in the Universal Consolidated Oil Co. well, Wiley No. 1. This southward thinning takes place over a distance of $2.8 \mathrm{~km}$ at a rate of about $280 \mathrm{~m}$ per kilometer. The Soquel is not present in the Olive oil field area farther to the south. These data indicate that the Soquel Member is an elongate predominantly sandstone body of lenticular cross section that has a line of maximum thickness (fig. 20) that trends northwestward; its thickness increases progressively from the outcrop area in Walnut Canyon to the vicinity of the Richfield Oil Corporation well, Peralta Hills No. 1, and thence to the Union Oil Co. well, Chapman No. 29. Directly north and west of the Chapman well, the Soquel Member has not been penetrated by drilling, but $3 \mathrm{~km}$ northwest, in the east end of the East Coyote oil field, it is more than $745 \mathrm{~m}$ thick.

The elongate lens is marked by abrupt thinning southwestward toward the line of pinchout and by moderate thinning in a northeasterly direction, a trend that continues farther north and east, in and beyond the Prado Dam quadrangle (Durham and Yerkes, 1964). There its lowest part is a conglomerate with boulders as much as $3 \mathrm{~m}$ in diameter.

$$
\text { AGE AND CORRELATION }
$$

No specifically identifiable fossils were found in the Soquel Member, and its age is based indirectly on foraminiferal faunas that were collected from the underlying La Vida and the overlying Yorba Members of the Puente Formation. The foraminiferal faunas of the La Vida are assigned to the lower part of Kleinpell's (1938) Mohnian Stage (Smith, 1960). On Burruel Ridge a single locality, m204 (Smith, 1960, loc. m17), in the overlying Yorba Member, yielded foraminifers that have been assigned to the upper part of Kleinpell's Mohnian Stage. Thus a provincial late Miocene age is inferred for the Soquel Member.

Along Loma Ridge, fragments of unidentified large oysters and pectinids are locally present in the coarsegrained sandstone of the Soquel Member. Near the head of Limestone Canyon, calcareous blocks in conglomerate near the base of the Soquel contain foraminifers assigned to the upper part of Kleinpell's Mohnian Stage and suggest that the base of the member may be slightly younger there than elsewhere.

Poorly preserved and crushed foraminifers are sparsely present in the interbedded siltstone units of the Soquel Member in the subsurface. In the Richfield oil field area, Wissler (1943) placed the Kraemer zone at the top of the Soquel Member in the upper part of Kleinpell's Mohnian Stage. 


\section{YORBA MEMBER}

The Yorba Member of the Puente Formation is exposed in the Burruel Ridge area. A small fault sliver of the Yorba is also present in the extreme northeastern corner of the map area and is the southern continuation of extensive exposures of the member in the Puente Hills (Durham and Yerkes, 1964).

SIKATK(RAPH' AND LITHOI()(i)

The contact between the Yorba Member and the underlying Soquel Member is believed to be gradational, although it is nowhere well exposed. In the eastern part of Burruel Ridge the lower part of the Yorba Member consists of gray to pinkish-brown indistinctly bedded to well-laminated siltstone containing sandstone interbeds as much as $2 \mathrm{~m}$ thick. The amount of sandstone decreases upward, and the siltstone increases in hardness and platiness, White to yellowish-brown limy concretions and concretionary beds a meter or so thick are common in this part of the sequence. In sections 10 and 15, T. 4 S., R. 9 W., at the western end of Burruel Ridge, the lower part of the member consists of friable, well-laminated, white to pinkish diatomite 90 to $120 \mathrm{~m}$ thick (Richmond, 1952, p. 8). This diatomite unit could not be traced eastward from this area, although sparse beds of white diatomaceous siltstone and shale are present locally in various parts of the section. The upper part of the Yorba Member consists of gray to pinkish-brown sandy siltstone. In many outcrops this siltstone is completely structureless; it weathers into irregular angular fragments. Beds of well-laminated gray to chocolate-brown siltstone, diatomaceous siltstone, and thin sandstone are locally interbedded in this pinkish-brown sandy siltstone. The upper contact is marked by a fairly abrupt lithologic change to coarsegrained gritty sandstone of the overlying Sycamore Canyon Member. This contact is poorly exposed and is believed to be conformable and gradational.

Estimates of the thickness of the Yorba Member are approximate because the dip varies over short distances, and small-scale folding distorts the bedding. A sketch section near the west line of section $11, \mathrm{~T}$. $4 \mathrm{~S}$., R. $9 \mathrm{~W}$., where the Yorba Member is unconformably overlain by the lower member of the Fernando Formation, indicates a thickness of approximately $340 \mathrm{~m}$. Structure section $G \cdot J$ (pl. 2). a short distance east of Walnut Canyon, indicates an outcrop thickness of about $150 \mathrm{~m}$, which suggests abrupt changes in thickness, a feature typical of all members of the Puente Formation.

$$
\text { SI'BSI'RFACI: DISTRIBULTION }
$$

The Yorba Member is present in the subsurface section north of Burruel Ridge and is differentiated west- ward to the pinchout line of the Soquel Member (fig. 20 ).

A thick lens composed almost entirely of sandstone is locally present in the subsurface section of the member. This sandstone is the Chapman sand or zone, a name of local usage among petroleum geologists. The name is derived from the Chapman lease in the Richfield oil field, where the Union Oil Co. obtained production from the zone on March 11, 1919 (Gardiner, 1943, p. 357).

Where it is recognized in the subsurface section, the Chapman sand consists of fine- to coarse-grained feldspathic sandstone and minor amounts of interbedded gray siltstone. Some siltstone interbeds are as much as $30 \mathrm{~m}$ thick and can be easily recognized on electric logs (structure section $A \cdot H$, pl. 2). Such a siltstone unit within the Chapman sand sequence in the Yorba Linda quadrangle to the north serves as a useful marker to divide the sand into upper and lower parts. Where wells are spaced closely enough for adequate control (structure section $A \cdot H$, pl. 2), the Chapman sand appears to grade laterally by interfingering into siltstone typical of the Yorba Member. This gradation is generally accompanied by a decrease in thickness, possibly reflecting differences in compactional response to loading.

The Chapman sand has been recognized in the subsurface northeast of a pinchout line that trends northwest from the mouth of Walnut Canyon (structure section $B-N$, pl. 2) to a pint about $340 \mathrm{~m}$ northeast of the General Petroleum Corporation well, Basin-Stern No. 1 ( structure section $A \cdot H$, pl. 2). The Chapman sand also appears in the Standard Oil Company well, Kraemer No. 2-25, and is recognized in other wells to the north (structure section $C-C, \mathrm{pl} .2$ ). Its westernmost limit is a line coincident with the southwestern boundary of the Richfield oil field. The Chapman sand was not identified in the Santa Ana Canyon Oil Company well, Crowthers No. 1, because of poor records, or in the outcrop area to the south, where it is either absent or concealed. Farther northeast, strucure section $\mathrm{H}-\mathrm{O}$ ( $\mathrm{pl}$. 2) suggests that the Chapman sand pinches out a short distance southeast of the Texas Co. well, Carrillo Ranch (NCT-1) No. 1.

The typical siltstone of the Yorba Member contains abundant interbedded sandstone in its lower part. On electric logs the contact between the Soquel and Yorba Members is selected as the point where sandstone becomes dominant. This depth can be easily determined in most areas, but in some areas the selection is arbitrary.

The Chapman sand is overlain by a silty shale that ranges in thickness from about 30 to $60 \mathrm{~m}$, commonly 
called the Chapman shale, by local petroleum geologists, and easily identified by electric logging. The top of this shale marks the conformable contact between the finer grained Yorba Member and the overlying coarser grained Sycamore Canyon Member. The Chapman shale is not differentiated southwest of the pinchout of the Chapman sand. In the area west of Burruel Ridge, where the Sycamore Canyon Member is absent (structure sections $A \cdot C, E \cdot L$, and $M \cdot F$, pl. 2), the lower member of the Pliocene Fernando Formation rests uncomformably on the Yorba Member.

The subsurface thickness of the Yorba Member is variable and depends largely on whether the Chapman sand is absent or present and the degree of lateral gradation into the Soquel Member. At the north margin of the map area, the Yorba Member is about $370 \mathrm{~m}$ thick in the Union Oil Co. well, Chapman No. 29. Between this well and the east side of the Kraemer oil field (structure section $A \cdot H$, pl. 2), the thickness of the Yorba increases to a maximum of about $600 \mathrm{~m}$. In the Texas Co. well, Carrillo Ranch (NCT-1) No. 1, a short distance to the east, only about $430 \mathrm{~m}$ is present. Along the south side of the Santa Ana River the maximum thickness for the member is about $410 \mathrm{~m}$ in the G. D. Murdock well, Howell No. 1. It thins westward to about $200 \mathrm{~m}$ in the Richfield Oil Corporation well, Peralta Hills No.1, and thence increases westward to about 400 $\mathrm{m}$ in the Universal Consolidated Oil Co. well, C \& T No. 1 , where strata assigned to the Yorba Member are lateral equivalents of part of the Soquel Member (structure section $B-N$, pl. 2).

The Chapman sand reaches its maximum thickness along a northwest-trending line between the G. D. Murdock well, Howell No. 1, where about $360 \mathrm{~m}$ is present, to the Pacific Central Oil Co. well, Boisseranc No. 1, where about $320 \mathrm{~m}$ is present (fig. 20). A little more than a kilometer farther southwest, this sand pinches out. The zero-thickness and maximumthickness lines of the Chapman sand are both northeast of those of the Soquel Member, and the pinchout of the Chapman sand is much more abrupt. It pinches out about $2 \mathrm{~km}$ southwest of the maximum line but thins much more gradually eastward and extends at least to Texas Co. well, Carrillo Ranch (NCT-1) No. 1, where it is $55 \mathrm{~m}$ thick. The line of maximum thickness of the Chapman sand is about $1.5 \mathrm{~km}$ northeast of the maximum of the Soquel.

\section{A(;L:ANI) CORREIATION}

Foraminifers and fish scales are present locally in surface exposures of the Yorba Member, but in most places, shell material has been removed by leaching and weathering. One diagnostic foraminiferal assemblage (locality $\mathrm{m} 204$ ), from near the base of the
Yorba Member northeast of Cerro Villa Heights, contains species that are assigned to the upper part of Kleinpell's (1938) Mohnian Stage (Smith, 1960, table 3 ). The massive, pinkish-brown, sandy siltstone that makes up the bulk of the upper part of the Yorba Member yielded no identifiable foraminifers.

Foraminifers and fish scales are commonly present in core samples from the Yorba Member, but no systematic attempt was made to collect or study them. Foraminifers from the Richfield oil field area were assigned by Wissler (1943) to the upper part of the Mohnian Stage and the lower part of Kleinpell's (1938) Delmontian Stage (late Miocene).

\section{SYCAMORE CANYON MEMBER}

The Sycamore Canyon Member of the Puente Formation is exposed on the north slope of Burruel Ridge between the west boundary of section 11 , T. 4 S., R. 9 W., and the south side of the Santa Ana River, a distance of $6 \mathrm{~km}$. Exposures are discontinuous north of the river in the vicinity of the Kraemer oil field.

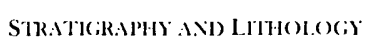

The contact between the sandstone of the Sycamore Canyon Member and the underlying siltstone of the Yorba Member appears to be conformable, despite a fairly sharp lithologic discontinuity in the Burruel Ridge area. Elsewhere it seems to be gradational through a meter or so of section. Just east of structure section $G \cdot J$ (pl. 2) and about $1 \mathrm{~km}$ south of the Rubicon Oil Co. well, Wilcox No. 1, the Yorba and Sycamore Canyon Members are bounded on the east by a north-trending fault, where the siltstone of the Yorba Member is truncated. The northward extension of this fault is questionable, because lithologically similar sandstone is juxtaposed across it. Richmond (1952, p. 10 and pl. 1) suggested that part of the strata mapped here as the Soquel Member may be the Sycamore Canyon locally overlapped onto the Soquel. This area may also be complicated by the presence of the Chapman sand, which is well defined in the Yorba sequence in both the Murdock and Rubicon wells to the northeast.

The basal part of the Sycamore Canyon Member consists mainly of coarse-grained to gritty poorly sorted, feldspathic, micaceous sandstone that ranges in weathered samples from gray to yellowish tan. Pebbles are scattered throughout the sandstone, and thin lenses of pebble conglomerate are present locally. Bedding in these units is generally poorly defined. Well-cemented, cliff-forming beds of sandstone as much as $3 \mathrm{~m}$ thick are traceable for considerable distances in some areas. A zone of ellipsoidal sandstone concretions as much as $1.5 \mathrm{~m}$ in maximum dimension is locally present in the basal part of the member. These concretions are well developed in the area north of Walnut Canyon, where 
they resemble cannonballs protruding from the enclosing less resistant sandstone. Concretions are tan and buff on weathered surfaces but light gray where freshly broken. The cementing material is calcium carbonate, and the bonding is so strong that the sand grains com. monly break instead of separating. Poorly developed concretionary horizons are also present locally in other parts of the Sycamore Canyon Member but are not as prominent as those at the base.

Sandstone higher in the Sycamore Canyon Member is slightly finer grained and contains abundant interbedded siltstone and sandy siltstone. the sandstone is feldspathic, micaceous, rather poorly sorted, and ranges from fine to coarse grained. Bedding is well developed, and the beds range from less than $3 \mathrm{~cm}$ to $3 \mathrm{~m}$ or more in thickness. The interbedded siltstone varies greatly in appearance. Some is massive and hackly and has the pinkish-brown color typical of that in the upper part of the Yorba Member. Other siltstone beds are gray and greenish gray, well laminated, and contain abundant flakes of greenish-black biotite.

Excellent exposures of the upper part of the Sycamore Canyon Member are evident in the roadcut south of the Riverside Freeway, where it cuts through an extensive outcrop about $370 \mathrm{~m}$ west of the east edge of the Orange quadrangle. There the member consists of a well-bedded sequence of sandstone and some siltstone, both of which are micaceous; sedimentary structures attributed to turbidity currents or density flows are common. The structures include graded bedding, crossbedding and cross-lamination, slump structures, and load casts. Some angular fragments of siltstone of the Sycamore Canyon are included in the sandstone as clasts together with rare pebbles and cobbles of other rock types.

The upper contact of the Sycamore Canyon Member is not exposed in the area northeast of Walnut Canyon. West of Walnut Canyon the contact between the Sycamore Canyon and the overlying lower member of the Fernando Formation appears to be gradational. In this area each of these units is composed of soft, micaceous sandstone of similar appearance, and the contact cannot be accurately located.

The exposed thickness of the Sycamore Canyon Member increases from west to east along the north slope of Burruel Ridge. At its western limit it is about $60 \mathrm{~m}$ thick (structure section $A \cdot K, \mathrm{pl} .2$ ), whereas $5 \mathrm{~km}$ to the northeast, about $460 \mathrm{~m}$ is present and the upper contact is covered by alluvium of the Santa Ana River.

SIBBSURLACE DISTRIBUTION

The Sycamore Canyon Member of the Puente Formation is widely distributed in the subsurface north of the outcrop area on Burruel Ridge through Peralta Hills and beyond the map boundary in the southern part of Placentia (structure sections $A \cdot C, E \cdot L$, and $M-F$, pl. 2).

Throughout its subsurface extent the basal part of the Sycamore Canyon Member is represented by sandstone overlying siltstone of the Yorba Member. This contact is sharp and easily recognized on the electric logs of the many wells available in this area. All evidence indicates that it is conformable and probably gradational through a meter or so of section.

In the vicinity of the Kraemer oil field and along the north side of Burruel Ridge the basal part of the Sycamore Canyon Member consists of gray, feldspathic, coarse-grained to gritty and locally pebbly sandstone that is poorly sorted and in some areas micaceous. The grain size of the lower sandstone decreases slightly toward the west; southwest of the Richfield oil field it is medium to coarse grained, and minor amounts of fine sandstone and sandy siltstone are interbedded. The upper part of the member in the eastern part of the area is a uniform sequence of interbedded fine- to coarse-grained gray feldspathic sandstone that locally contains abundant biotite flakes. Bedding of this sandstone ranges from thin laminae to beds several meters thick. Variable amounts of gray and greenish. gray micaceous siltstone and sandy siltstone are interbedded throughout this sandstone but nowhere make up more than 10 or 15 percent of the total. The siltstone occurs as thin laminae in a predominantly sandstone sequence and as discrete beds about a meter thick.

The general lithologic character of the Sycamore Canyon Member changes systematically from east to west: The sandstone is increasingly finer grained and siltstone increasingly more abundant as the pinchout line at the southwest is approached. South and west of Atwood, siltstone is locally predominant in the middle part of the Sycamore Canyon and is enclosed by welldeveloped sandstone beds. Southwest of the Richfield oil field the Sycamore Canyon becomes uniformly silty and contains as much as 50 percent siltstone interbedded with the sandstone.

The top of the Sycamore Canyon Member is easily recognized in the Richfield oil field area, where the contact is sharp and distinct between sandstone of the Sycamore Canyon and siltstone of the lower member of the Frenando Formation. This contact is believed to be a local unconformity. The member thins to the south ( structure section $A-C, \mathrm{pl} .2$ ). It is missing in the Olive oil field area and in the outcrops on the western part of Burruel Ridge where the lower Member of the Fernando Formation rests on the undifferentiated La Vida and Yorba Members. The lower member of the Fernando Formation grades laterally eastward from the Richfield oil field into a dominantly sandstone sequence similar to that in the Sycamore Canyon. Where 
the units are coarse grained, the contact cannot be distinguished on electric logs (structure section $A-H$, pl. 2 ) and appears gradational. This gradational contact is also present in the outcrop area of the Sycamore Canyon south of the Santa Ana River and west of Walnut Canyon.

The thickness of the Sycamore Canyon Member in the subsurface increases toward the east and reaches an apparent maximum in the subsurface of the Kraemer oil field. The northwesternmost well to penetrate the member in the map area is Texas Oil Co. well, Kraemer No. 1, in the eastern part of Placentia; about $20 \mathrm{~m}$ of Sycamore Canyon is present in this well. The average thickness in the group of wells southwest of the Richfield oil field is about $60 \mathrm{~m}$. From there the thickness increases gradually eastward; about $250 \mathrm{~m}$ is present in the Texas Co. well, Vejar No. 1, and thence it increases rapidly to at least $760 \mathrm{~m}$ in the Richfield Oil Corp. well, Mohawk-Kraemer No. 1, in the Kraemer oil field area (structure section $A-H$, pl. 2). East of the Kraemer oil field the member thins to a minimum of about $410 \mathrm{~m}$ in the Texas Co. well, Carrillo Ranch (NCT-1) No. 1. South of the Santa Ana River the only well to penetrate a complete section of the Sycamore Canyon Member is the Richfield Oil Corp. well, Peralta Hills No. 1, which spudded some distance below the top of the member.

The line of maximum thickness of the Sycamore Canyon Member (fig. 20) trends northwestward from the outcrop area east of the Landers well through the Kraemer oil field; this is a trend similar to that already noted for the Soquel Member and the Chapman sand in the Yorba Member, but it is shifted to the northeast in relation to these older units.

$$
\text { A(FEAND CORRELATON }
$$

Although diagnostic fossils are sparse, the Sycamore Canyon Member is marine and probably was deposited in moderately deep water. It overlies the Yorba Member, which contains foraminifers that are assigned to the upper part of Kleinpell's (1938) Mohnian Stage, and it underlies the Fernando Formation, which contains mollusks of Pliocene age. Here, as in areas to the northwest where the strata include determinable fossils, it is considered to be of provincial latest Miocene age.

\section{MIOCENE AND PLIOCENE SERIES UPPER MIOCENE AND LOWER PLIOCENE CAPISTRANO FORMATION}

The Capistrano Formation was named by Woodford (1925, p. 216-217) for exposures in the vicinity of San Juan Capistrano, about $20 \mathrm{~km}$ south of the map area. There it is composed mostly of siltstone. It grades northward into massive white coarse-grained to gritty sandstone that has been named the Oso Member of the Capistrano Formation (Vedder and others, 1957; Vedder, 1972).

OSO MEMBER

The Oso Member of the Capistrano Formation is exposed only in the southernmost part of the map area, from near the mouth of Bee Canyon southeastward across Agua Chinon Wash. Its type area, about $8 \mathrm{~km}$ south of the map area, is between Agua Chinon Wash and Oso Creek approximately $4 \mathrm{~km}$ east of El Toro (Vedder and others, 1957). Its friable sandstone forms smooth rounded slopes that support a sparse growth of brush and cactus. Most of the outcrop area is covered by sandy soil, although fresh exposures are present in the banks of the larger streams.

\section{STRATIG:RAPHY AND LTHOI:OG}

From Borrego Canyon westward to Bee Canyon, the Oso Member either is faulted against or apparently is conformable on the underlying Soquel Member of the Puente Formation. Farther to the southeast the Oso Member is unconformable on the Monterey Shale (Vedder and others, 1957). In the area east of Agua Chinon Wash, the uppermost unit in the Soquel Member is a light-gray to chocolate-brown siltstone; this siltstone is conformably overlain by a friable white coarse-grained to gritty sandstone of the Oso Member. Between Round Canyon and Bee Canyon the poorly exposed contact between the Oso and the Soquel may be gradational; the primary difference between the two is that the Soquel contains numerous conglomerate beds, whereas the overlying sandstone of the Oso is only sparsely conglomeratic. Within the map area, the sandstone bed overlying the highest persistent conglomerate bed of the Soquel has been chosen as the base of the Oso. The sandstones in the two units are indistinguishable, and the conglomerate at most places is expressed only as float in the soil.

From its base upward the Oso Member consists of uniform massive sandstone with no distinctive lithologic or structural features. It is generally and erosionally weak, friable, white to pale-yellowish-gray, medium- to coarse-grained to gritty sandstone that is composed of subangular grains of quartz and feldspar. Widely scattered flakes of golden-brown to greenishblack weathered biotite are present as well as subrounded fragments of various rock types. Scattered pebbles and cobbles are present. In some outcrops the sandstone is fairly clean and friable, and in others it is slightly cemented and has a matrix of soft, clayey material.

The Oso Member from Bee Canyon southeastward to the edge of the map area is overlain unconformably by Quaternary terrace deposits and alluvium. Farther 
south it is overlain conformably be the uppermost part of the Capistrano Formation and the Niguel Formation (Vedder and others, 1957; Vedder 1972, fig. 4).

The thickness of the Oso Member is difficult to estimate because of poor dip control and the unconformity at its upper boundary. Vedder and others (1957) reported a thickness of about $450 \mathrm{~m}$ along Serrano Creek $2 \mathrm{~km}$ southeast of the map area, but later structure sections (Vedder, 1975) suggest that it is nearer to $300 \mathrm{~m}$ thick there. Structure section $T \cdot X$ (pl. 3) indicates a maximum thickness of about $490 \mathrm{~m}$.

\section{A(BRANI) CORRLAATION}

Fossils other than shark teeth and whale bones are rare in the Oso Member. About $6 \mathrm{~km}$ to the south near English Canyon, numerous distorted specimens of a large echinoid were collected; these were identified as Megapetalus lovenioides Clark by Zullo and Durham (1962), and some poorly preserved foraminifers were found near the top of the member. Ellipsoglandulina fragilis Bramlette(?), a foraminifer indicative of Kleinpell's upper Mohnian or Delmontian Stage, has been reported by Vedder and others (1957) from their locality 737b, near the top of the member between Oso and Aliso Creeks. The siltstone of the Capistrano Formation, into which the Oso Member grades laterally, is more fossiliferous in the area between San Juan Capistrano and Dana Point, where it contains late Miocene and early Pliocene fossils (White, 1956; Ingle, 1971; Vedder, 1972). The Oso Member probably is the stratigraphic equivalent of the lower part of the Capistrano Formation (Vedder, 1972, fig. 4) and seems to be no younger than provincial late Miocene. Its correlatives in the Burruel Ridge area would thus probably include part of the Yorba Member and possibly part of the Sycamore Canyon Member of the Puente Formation.

\section{PLIOCENE SERIES}

The stratigraphic nomenclature of the Pliocene rocks in the Los Angeles basin has a complex history that is discussed in detail by Durham and Yerkes (1964, p. B24, B25) in their report on the geology of eastern Puente Hills.

\section{FERNANDO FORMATION}

Durham and Yerkes (1964) redefined the Fernando Group as a rock-stratigraphic unit of formation rank which encompasses Pliocene strata of the northernmost part of the Santa Ana Mountains and the southernmost part of the eastern Puente Hills (pl. 1). In these areas the formation is divisible into a lower and an upper member. In the Santa Ana Mountains, the Fernando is exposed only at Burruel Ridge; north of the Santa Ana River, it is exposed in the vicinity of Kraemer oil field.

\section{LOWER MEMBER}

The lower member of the Fernando Formation is exposed along the north slope of Burruel Ridge from Walnut Canyon westward to near the town of Olive. North of the Santa Ana River and northwest of Kraemer oil field it crops out in several small areas that are continuous with more extensive exposures to the north (Durham and Yerkes, 1959, 1964).

The lower member on Burruel Ridge overlies, from west to east, the undifferentiated La Vida and Yorba, the Yorba, and the Sycamore Canyon Members of the Puente Formation. In the same area, the contact between the lower member and the underlying units is unconformable - marked by a basal conglomerate - at the west, becoming apparently conformable and gradational with the Sycamore Canyon at the east. The lower part of the lower member appears to grade laterally from greenish-gray micaceous sandy siltstone in the western exposures to fine- to coarse-grained micaceous sandstone in the eastern exposures. In the Puente Hills to the north, the basal contact is concealed. There the lower member of the Fernando is mostly massive, coarse-grained, pebbly sandstone. Some interbeds of well-laminated sandy siltstone with biotite are also present.

\section{STRATIGRAPHY AND LITHOLOGY}

The lower part of the lower member of the Fernando Formation, on the north side of Burruel Ridge from Olive eastward for $3 \mathrm{~km}$, consists of conglomerate and breccia (fig. 21), which rests unconformably on the undifferentiated La Vida and Yorba Members and the Yorba Member of the Puente Formation. It locally is at least $6 \mathrm{~m}$ thick and consists of subangular to subrounded pebbles, cobbles, and boulders with a maximum diameter of about $1.5 \mathrm{~m}$. Richmond (1952, p. 11) reported that the clasts are composed mainly of quartzite, granodiorite, and volcanic rocks (chiefly purple andesite). Blocks of calcareous siltstone bored by pholads also occur. The matrix is yellowish-brown coarse-grained poorly sorted sandstone locally cemented by calcium carbonate. Marine mollusks are present in the cemented parts of the conglomerate. In the steep gully just west of a landslide in the western part of sec. 11, T. 4 S., R. 9 W., the lowest $15 \mathrm{~cm}$ of the Fernando is a sandy pebble-cobble conglomerate, overlain by pale-gray to tan pebbly sandstone, that rests directly on siltstone of the Yorba Member. The contact undulates and is irregular, and there is a discordance in bedding. The variations in attitude, the abrupt change in lithologic character, and the absence of the Sycamore Canyon Member of the Puente Formation, which is present directly east of the landslide, are evidence of the unconformity. East of the landslide the 
basal conglomerate is absent, and coarse sandstone of the lower member appears to rest conformably and gradationally on sandstone of the Sycamore Canyon. In the eastern Puente Hills the basal contact of the lower member is concealed by faulting or by younger units (Durham and Yerkes, 1964, p. B25, B26).

The upper part of the lower member is predominantly sandy siltstone that includes interbeds of coarse-grained sandstone and conglomerate.

The upper contact of the lower member is exposed only on the west end of Burruel Ridge where greenishgray siltstone is overlain unconformably by conglomerate assigned to the upper member of the Fernando Formation.

North of the Santa Ana River, within the map area, the basal contact is concealed by faults or by younger units. The best exposures of the lower member of the Fernando Formation are in the excavations made for the Patrick A. Doheny wells $1 \mathrm{~km}$ west of the Kraemer oil field. This exposure consists of coarse-grained pebbly sandstone that is poorly sorted and massive. The sandstone contains interbedded well-laminated greenish-gray sandy clayey siltstone that locally contains large amounts of partly leached biotite ranging in color from green to greeish brown to almost black. Graded bedding and cross-lamination are also present.

The upper part of the lower member of the Fernando Formation on Burruel Ridge consists chiefly of friable, easily eroded siltstone and fine-grained sandstone, some interbeds of coarse-grained sandstone, and thin lenticular conglomerate beds. The siltstone and finegrained sandstone are pale greenish gray, and mica is

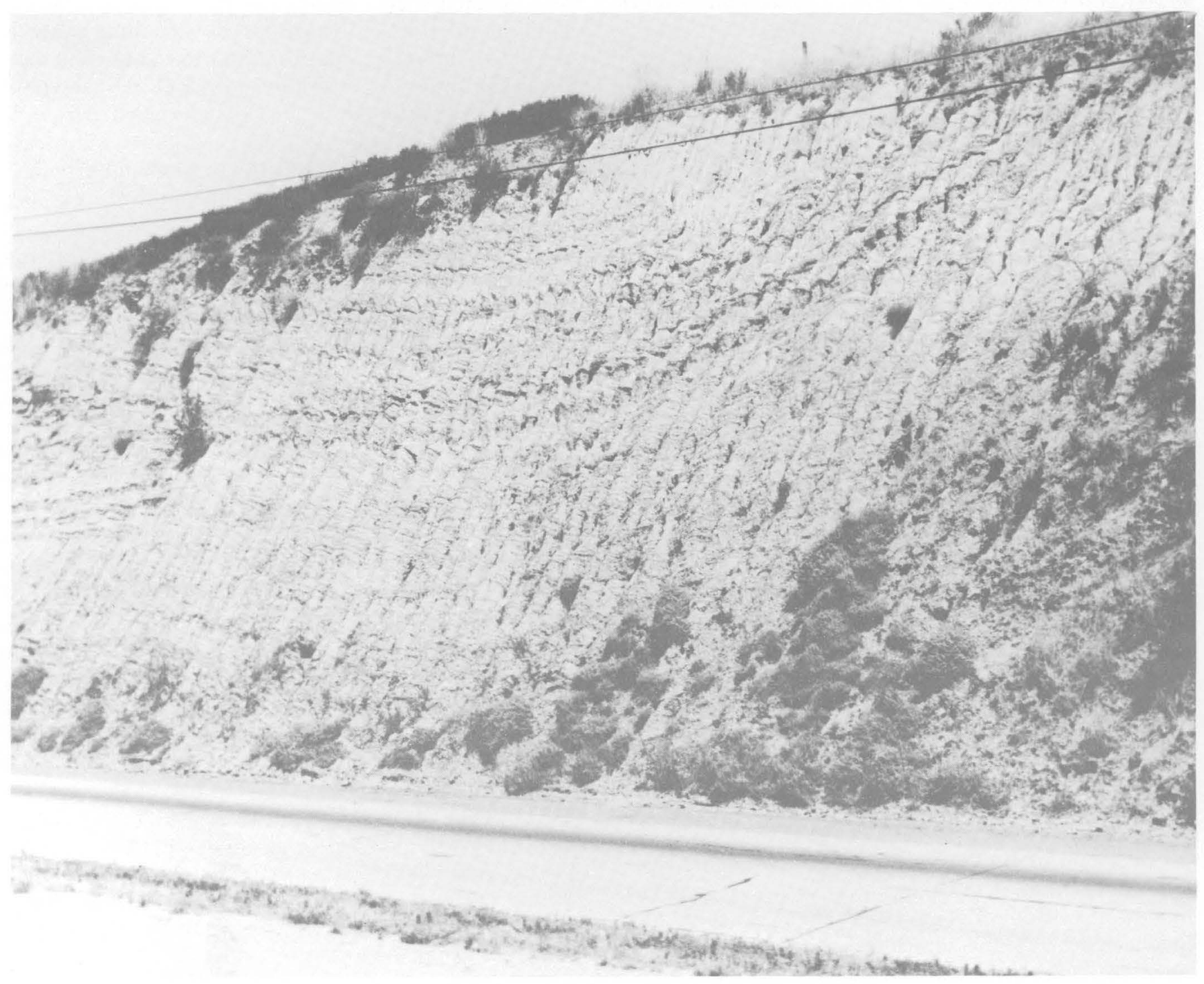

FIgURE 21.- Lower member of the Fernando Formation in roadcut in Riverside Freeway cut. Note conglomerate bed at lower left. Minor fault at right. Vertical dimension of cut is about $10 \mathrm{~m}$. View northwest. 
so abundant that bare surfaces have a micaceous sheen. Beds of friable cleanly sorted medium- to coarse-grained light-gray to tan feldspathic sandstone up to about a meter thick are interbedded within the siltstone. These sandstone beds lend a well-bedded appearance to the massive siltstone. High in the member, in the freeway cut east of Olive, conglomerate lenses are as much as $0.6 \mathrm{~m}$ thick. The clasts are moderately well rounded and average from 5 to $10 \mathrm{~cm}$. Pebbles, cobbles, and boulders in the soil of the slopes to the east suggest that conglomerate lenses are also present there.

A 0.3-m-thick bed of bone-white tuff in greenish-gray micaceous siltstone and fine-grained sandstone of the lower member is exposed in a Riverside freeway cut $500 \mathrm{~m}$ northeast of the intersection with Jefferson Street at the northwest edge of Burruel Ridge. Samples of this tuff were examined by A. O. Woodford, who reported that it consists mainly of glass shards with an index of refraction between 1.505 and 1.508. Also present are clastic grains of quartz, biotite, rare muscovite, and abundant unidentified clay mineral. The clay mineral and biotite are partially concentrated in fragments as long as $4 \mathrm{~mm}$. These fragments suggest some erosion and reworking of the tuffaceous materal. Thin beds of volcanic ash and bentonite have been reported from approximately equivalent rocks in the southwestern part of the Los Angeles basin (Wissler, 1943, p. 216-217; Woodring and others, 1946, p. 41) and in several subsurface localities along the northern shelf of the basin (T. H. McCulloh, 1977, oral commun.).

The only exposure of the upper contact of the lower member of the Fernando Formation is at the west end of Burruel Ridge near Olive. There, the greenish-gray siltstone of the lower member is overlain in sharp contact by conglomerate of the upper member. The abrupt eastward thinning of the lower member on Burruel Ridge and its proximity to the window of the Puente Formation at its westernmost exposure indicate that the contact is an erosional unconformity. The contact in the area north of the Riverside Freeway is poorly exposed and is placed at the base of the lowest conglomerate float in the soil.

The maximum exposed thickness of the lower member of the Fernando Formation on Burruel Ridge is uncertain. Structure section $A \cdot K$ ( $\mathrm{pl} .2$ ) suggests a thickness of about $300 \mathrm{~m}$, where the member is unconformably overlain by Quaternary terrace deposits. At the west end of Burruel Ridge, where both the lower and upper contacts are unconformities, structure section $M \cdot F$ ( $\mathrm{pl} .2$ ) indicates a partial thickness of about $60 \mathrm{~m}$.

$$
\text { SUBSURFACE DISTRIBUTION }
$$

The lithology of the lower part of the lower member of the Fernando Formation and its relations to the un- derlying Puente Formation are variable in the map area. In the Union Oil Co. well, Chapman No. 29, just northwest of the map area the lower contact occurs at a depth of $790 \mathrm{~m}$ and is marked by a sharp change from siltstone above to sandstone below. This contact was considered an unconformity by Wissler (1943, p. 218). It can be traced eastward (structure section $A-H$, pl. 2) only with difficulty, as the Fernando seems to grade downward into the Sycamore Canyon Member of the Puente Formation in a fashion parallel with the change that occurs in the outcrop at the east end of Burruel Ridge (structure section $E \cdot L$, pl. 2). In wells on the south limb of the syncline north of Burruel Ridge, the Sycamore Canyon Member is absent, and part of the lower member of the Fernando is composed of a variable thickness of sandstone and conglomerate that rests directly on the undifferentiated La Vida and Yorba Members. The absence of the Sycamore Canyon Member and the southward coarsening of the lower part of the lower members of the Fernando are evidence that the unconformity reported in the Richfield oil field increases in magnitude southward.

In the subsurface the major part of the lower member consists of greenish-gray micaceous siltstone, sandy siltstone, fine-grained sandstone, and varying amounts of interbedded gray medium- to coarsegrained sandstone. The upper contact is placed at the top of this siltstone sequence and directly below the conglomerate and sandstone that unconformably overlie it. This contact is easily recognized on electric logs and is correlated with the upper contact as mapped at the west end of Burruel Ridge.

The thickness of the lower member increases southward from $220 \mathrm{~m}$ in the Union Oil Co. well, Chapman No. 29, just north of the map area to a maximum for the area of $670 \mathrm{~m}$ in the Texas Co. well, Hodges No. 1. It thins sharply south of the Olive oil field and is cut out by younger beds (structure sections $E \cdot L$ and $M-F$, pl. 2). Eastward from the Olive oil field it thins from about $580 \mathrm{~m}$ in the Texas Co. well, Olive Unit One No. 2 , to about $300 \mathrm{~m}$ in the Seaboard Oil Co. well, Christensen No. 1 (structure section $B \cdot N$, pl. 2).

\section{AGE AND CORRELATION}

Marine mollusks and foraminifers from the lower member of the Fernando Formation are cited in the sections "List of Megafossils" and "List of Microfossils." Four of the molluscan localities (F175, F176, and F178 from the basal conglomerate and F177 from higher in the section) were collected and identified by Richmond (1952, p. 11). These specimens are in the collections of Pomona College, Claremont, Calif., and were loaned for reexamination and identification by $\mathrm{W}$. P. Woodring and Ellen J. Moore of the U.S. Geological Survey. 
Concerning the age and bathymetric depth ranges of these faunas, W. P. Woodring and Ellen J. Moore (1952, written commun.) report: "The age of two of these collections (F174 and F175), consisting of poorly preserved or incomplete specimens, cannot be designated more closely than 'presumably Pliocene'. The few species in the other collections do not afford a basis for differentiating early and late Pliocene. Thyasira gouldii is a moderate-depth species. The other species indicate shallow water."

The foraminifers indicate early Pliocene age and a bathyal depth and are similar to early Pliocene foraminiferal faunas from the upper part of the Capistrano Formation in the San Juan Capistrano area described by White $(1956 ; 1971)$ and Ingle $(1967 ; 1971)$ and the lower part of the Fernando Formation at Upper Newport Bay (Vedder, 1972, 1975; Ingle, 1972), although a smaller number of species is represented. Uvigerina peregrina, Epistominella subperuviana, and several species of Cassidulina, which constitute 50 to 75 percent of these faunas, suggest bathyal depth interpretations of around $600 \mathrm{~m}$ or more.

The lower member of the Fernando Formation, provincial early Pliocene in age, is widely distributed in the Los Angeles basin (Yerkes and others, 1965, p. A38-A41, fig. 11) It is referred to informally as the Repetto Formation in the Palos Verdes Hills, Wilmington and Long Beach oil field, and Repetto Hills areas; it is equivalent to the upper part of the Capistrano Formation in the San Joaquin Hills (White, 1956; Yerkes and others, 1965, pls. 1, 2; Ingle, 1972; Vedder, 1972).

\section{UPPER MEMBER}

The upper member of the Fernando Formation is exposed only at the western tip of Burruel Ridge just east of the town of Olive. North of the Santa Ana River, south-dipping strata assigned to the upper member by Durham and Yerkes $(1959,1964)$ are present along the south margin of the Puente Hills.

Exposures of the upper member are poor, for it is poorly consolidated and forms smooth, rounded slopes that support a growth of grass, low brush, and clumps of cactus. The best exposures are at the western tip of Burruel Ridge and in the abandoned gravel pit a short distance to the east.

\section{STRATIGRAPHY AND LITHOLOGY}

The lower part of the upper member of the Fernando Formation consists of interbedded tan and yellowishbrown coarse-grained sandstone and conglomerate in variable proportions. It rests unconformably on siltstone of the lower member; the contact is placed at the base of the lowest mappable conglomerate bed. In a roadcut of the Riverside Freeway this lowest conglomerate is overlain by a gray micaceous sandy siltstone that is lithologically identical with that present in the lower member. Unsorted and indistinctly bedded conglomerate and sandstone overlie this sandy siltstone. The conglomerate is composed of pebbles, cobbles, and boulders up to about $30 \mathrm{~cm}$ in maximum diameter, but they average 5 to $8 \mathrm{~cm}$ and include many as small as sand size. Clasts are composed of many rock types, including several types of volcanic rock, some of which are similar to the Poway-type clasts in conglomerate of the undifferentiated Sespe and Vaqueros Formations plus schist and gneiss, plutonic rocks, and some lightcolored quartzite. These conglomerate beds are lenticular and grade vertically and laterally into the poorly sorted feldspathic sandstone beds that contain a small amount of leached biotite. All gradations are present between sandstone and conglomerate. The highest unit exposed is a soft, easily gullied and very poorly bedded fine-grained sandstone.

The upper member is unconformably overlain by flat-lying Quaternary terrace deposits and alluvium. The contacts between these units generally are covered by soil and can be located only approximately.

The exposed thickness of the composite upper member is about $30 \mathrm{~m}$, which probably represents only the lower part of the member.

\section{SUBSURFACE DISTRIBUTION}

The upper member of the Fernando Formation underlies a more extensive area than does the lower member and extends into the southern part of the map area. Along the north side of Burruel Ridge, the upper member is present in the entire area west of State Highway 14. South of Olive the upper member forms a broad strip that extends along the western edge of the map area, except east of the Standard Oil Co. well, Tustin Comm. No. 1, where it is believed to be absent. The upper member cannot be differentiated east of the Amerada Petroleum Corp. well, Irvine No. 63-1 (structure section $R \cdot S$, pl. 3 ; see also Yerkes and others, 1965, fig. 14).

North of the vicinity of the Union Oil Co. well, Olive Comm. No. 4-1 (structure section $A-C$, pl. 2), the upper member of the Fernando Formation rests on the lower member. A few core samples from the Texas Co. well, Olive Comm. No. 1, indicate that the upper member is composed of an alternating sequence of friable sandstone, conglomerate, and micaceous siltstone that contains some black carbonaceous material. Fragmen. tary remains of mollusks are present in some of the coarser grained units, and foraminifers are reported from some of the siltstone beds. North of the Texas Co. well the electric logs from all wells that penetrate the 
base of the upper member show a sharp contact between the sandstone and conglomerate of the upper member and the finer grained siltstone of the lower member. This contact is similar to that exposed in the outcrops at the west end of Burruel Ridge.

In the area south and east of the Union Oil Co. well, Olive Comm. No. 4-1, and the Tidewater Oil Co. well, Olive-Orange No. 1, where the lower member of the Fernando Formation is not present, the upper member rests directly on older formations. In the area of the Standard Oil Co. well, Taft Comm. No. 1, the upper member rests on the undifferentiated La Vida and Yorba members of the Puente Formation, whereas southeast of Orange it is believed to rest on the bevelled edges of the El Modeno Volcanics, the Topanga Formation, and the undifferentiated Sespe and Vaqueros Formations (structure sections $E \cdot L$, pl. 2, and $L-Q$, pl. 3). A few cores were recovered from the upper member in the Shoreline Oil Co. well, Pinkerton No. 1, and are reported to consist mainly of blue clay, silt, and sandstone, containing some molluscan fragments and foraminifers. Conglomerate is also believed to be present, although it was not cored. A sharp contact is reported at $554 \mathrm{~m}$ in this well, where red beds of the undifferentiated Sespe and Vaqueros Formations occur below the upper member of the Fernando Formation.

In several wells south and east of Santa Ana, friable sandstone, conglomerate, and siltstone of the upper member rest on the undifferentiated La Vida and Yorba Members (Amerada Petroleum Corp. well, Irvine No. 63-1; Red Star Oil Co. well, Ward Associates No. 1; and Hoyt S. Gale well, Irvine No. 1). These wells are so widely separated and the available data so poor that correlation with the upper member in the area north of Orange is questionable. In the southern area the upper member may include marine equivalents of the La Habra Formation of Pleistocene age, which is not known to be present in the Red Star Oil Co. and the Hoyt S. Gale wells.

The upper member of the Fernando Formation is believed to rest unconformably on formations older than the lower member throughout the subsurface area; these relations are especially clear south of Olive, where the lower member is absent and older formations are present beneath the unconformity.

Electric logs indicate that the upper part of the upper member is finer grained, especially in the area north of Olive where more siltstone is interbedded. The contact with the overlying La Habra Formation is believed to be an unconformity. The La Habra is coarser grained and nonmarine in origin. In the subsurface the upper contact of the La Habra cannot be distinguished from rocks of several other formations because of the nondiagnostic characteristic of the rocks as recorded in electric logs.
The thickness of the upper member of the Fernando Formation is extremely variable. About $250 \mathrm{~m}$ is present in the Union Oil Co. well, Chapman No. 29, at the north edge of the map area. The member thickens rapidly to the south and is thickest near the Texas Co. well, Ruff No. 1, where about $920 \mathrm{~m}$ is present (structure section $A-C$, pl. 2). Farther south it thins rapidly and is absent in Standard Ol Co. well, Tustin Community No. 1 ( structure section $E-L$, pl. 2). About $220 \mathrm{~m}$ is present in the Shoreline Oil Co. well, Pinkerton No. 1, and about $280 \mathrm{~m}$ in the Amerada Petroleum Corp. well, Irvine No. 63-1. In the extreme southwestern part of the area, strata tentatively assigned to the upper member have a minimum thickness of about $610 \mathrm{~m}$ in the Red Star Oil Co. well, Ward Associates No. 1, and about $370 \mathrm{~m}$ in the Hoyt S. Gale well, Irvine No. 1.

\section{AGE AND CORRELATION}

No fossils of any kind were found in exposures of the upper member of the Fernando Formation in the map area. Foraminifers and poorly preserved mollusks are reported in it outside of the map area, where the species generally indicate marine deposition in shallow water. In the Puente Hills to the north (Durham and Yerkes, 1964, p. B26, B27) large molluscan faunas of late Pliocene age were found at several localities in the upper member. Depths greater than $50 \mathrm{~m}$ and as much as $200 \mathrm{~m}$ are suggested by molluscan assemblages at Newport Bay in the uppermost part of the Fernando Formation (Vedder, 1972).

The upper member of the Fernando Formation, assigned a provincial late Pliocene age, is widely distributed in the Los Angeles basin (Yerkes and other, 1965, p. A41-A44, fig. 14). Vedder (1960, 1972) provisionally correlated these strata with the Niguel Formation in the San Juan Capistrano area and the upper part of the Fernando Formation at Newport Bay.

\section{NIGUEL FORMATION}

The Niguel Formation was named by Vedder and others (1957) for exposures on the Niguel land grant in the San Juan Capistrano quadrangle. The type area, about $13 \mathrm{~km}$ south of the map area, is immediately west of Galivan Overpass on former U.S. Highway 101 (1949 edition, San Juan Capistrano quadrangle) about $7 \mathrm{~km}$ north of San Juan Capistrano. The formation unconformably overlies Monterey Shale and the Capistrano Formation and is overlain unconformably in turn by Quaternary stream deposits. It is chiefly poorly consolidated light-gray to white micaceous feldspathic sandstone interbedded with gray sandy siltstone. Conglomerate and breccia are locally present near the base. South of the map area, the formation is mostly marine, and molluscan assemblages in the lower part 
were assigned a provincial late Pliocene age by Vedder $(1960,1972)$. The upper part of the formation lacks fossils and may be nonmarine. Fossils have not been found in the formation within the map area. Structure section $T-X$ (pl. 3 ) indicates a thickness of about 150 $\mathrm{m}$.

The Niguel Formation is exposed in four small patches along the southern edge of the map area, between the mouth of Round Canyon and Agua Chinon Wash. Its westward extension beneath the alluvium is terminated by the fault that trends south from Bee Canyon and passes just west of the Lambert Reservoir. Smooth, rounded, cobble-strewn hills covered by a growth of low brush and clumps of cactus are typical of the Niguel Formation. Grass rather than brush grows on the black clayey soil developed on the underlying Monterey Shale, and this change in vegetation and soil is used to define the contact between the two units in most places.

\section{STRATIGRAPHY AND LITHOLOGY}

Only the lower part of the Niguel Formation is present in the map area. It consists of coarse-grained poorly sorted yellowish-brown sandstone and interbedded massive conglomerate that locally contains blocks of calcareous siltstone derived from either the Monterey Shale or the Puente Formation. Many of these siltstone blocks have been bored by pholads, which suggests that the siltstone was redeposited in water not deeper than about $35 \mathrm{~m}$ (Revelle and Fairbridge, 1957, p. 280). Vedder (1960) stated that molluscan assemblages from the Niguel outside the map area suggest and inner sublittoral-depth facies (low water to about $100 \mathrm{~m}$ ).

The best exposures of the Niguel Formation in this area are in a gravel pit about $150 \mathrm{~m}$ south of the westernmost natural outcrop of the formation. There, the formation consists of a complex sequence of interbedded sandstone, conglomeratic sandstone, and conglomerate. In fresh exposures the sandstone is white to very pale greenish gray, fine to coarse grained, poorly sorted, and feldspathic. Some thin clayey streaks impart a well-bedded appearance to the sandstone. Slightly darker colored tubes $2 \mathrm{~cm}$ in diameter and 2 to $8 \mathrm{~cm}$ long are present in the sandstone. These are usually perpendicular to the bedding, and the sand grains in the tubes are coarser and "cleaner" than the surrounding sandstone, which suggests activity by burrowing mollusks, crustaceans, or worms. The sandstone and the conglomerate occur as lenses and pods that are indistinctly crossbedded. The conglomerate is light yellow brown and is composed of completely unsorted clasts that range in size from 2 to about $30 \mathrm{~cm}$ in maximum diameter and average from 5 to $10 \mathrm{~cm}$. The clasts range from subangular to rounded and consist of volcanic rocks in various shades of gray, red, and maroon that were probably derived from the undifferentiated Sespe and Vaqueros Formations, plus plutonic rocks, quartzite, gneiss, and other metamorphic rocks. Some clasts of very friable greenish-gray clayey sandstone up to $10 \mathrm{~cm}$ in diameter are also present. The matrix of the conglomerate is very poorly sorted feldspathic sandstone having angular to subrounded grains. Thin surface coatings of clayey material hold the grains together, and the sandstone and conglomerate in the quarry stands as cliffs that are rapidly gullied during wet seasons. Fossils other than filled burrows have not been found in the Niguel Formation within the map area.

\section{QUATERNARY SYSTEM PLEISTOCENE SERIES LA HABRA FORMATION}

The name La Habra Conglomerate was used by H. M. Bergen in as unpublished report on the geology of the Bastanchury ranch (in the vicinity of Fullerton and Brea), and the name was first published by Eckis (1934, p. 49-50). Durham and Yerkes (1959), during mapping of the area northwest of the Santa Ana Mountains, reexamined the type La Habra and, bécause of the wide variety of lithologic types, renamed it the La Habra Formation. In the type area between Brea and Carbon Canyons in the La Habra and Yorba Linda quadrangles, it consists of buff conglomerate and conglomeratic sandstone that contain angular chips and blocks of white siltstone, reddish earthy sandstone, and greenish-gray massive siltstone. The base of the La Habra Formation is a regional unconformity that transgresses marine sandstone and conglomerate of early Pleistocene age in the La Habra quadrangle and the upper and lower members of the Fernando Formation in areas to the east along the south flank of the Puente Hills. The base of the La Habra is not exposed in the Santa Ana Mountains. The La Habra is unconformably overlain by Quaternary terrace deposits and alluvium. Durham and Yerkes (1959) mapped the La Habra Formation eastward as far as the town of Yorba Linda and discussed its presence in the subsurface as far south as the edge of the Yorba Linda quadrangle where it adjoins the Orange quadrangle.

The only exposure of the La Habra Formation in the map area is in the gravel pit on the north edge of the Orange quadrangle about $3 \mathrm{~km}$ east of the town of Atwood (fig. 22). It is surely present beneath alluvium in all the wells drilled for oil north of the Santa Ana River and west of the Yorba bridge across the Santa Ana River. South of the river the subsurface correlations are more questionable, and south of the town of Orange the wells are so widely separated and the sub-. 
surface information so sparse and inconclusive that the term La Habra Formation is used only tentatively for the post-Pliocene rocks that are known to underlie the alluvium.

\section{STRATIGRAPHY AND LITHOLOGY}

The base of the La Habra Formation is not exposed in the map area. About $2 \mathrm{~km}$ north of Yorba Linda, south-dipping massive white conglomeratic sandstone at the base of the La Habra (Durham and Yerkes, 1959) rests unconformably on siltstone and conglomerate of the upper member of the Fernando Formation.
The base of the La Habra Formation is at $307 \mathrm{~m}$ depth in the Union Oil Co. well, Chapman No. 29, at the north edge of the map area (Durham and Yerkes, 1964), where it is underlain by the upper member of the Fernando Formation. In most other wells the contact is obscure and questionable. The La Habra rests on the upper member of the Fernando Formation as far south as the Standard Oil Co. well, Zaiser-Brejli Comm. No. 1, but south of there the data are inconclusive. At the Standard Oil Co. well, Tustin Comm. No. 1, the La Habra Formation rest unconformably on undifferentiated siltstone of the Puente Formation. South of

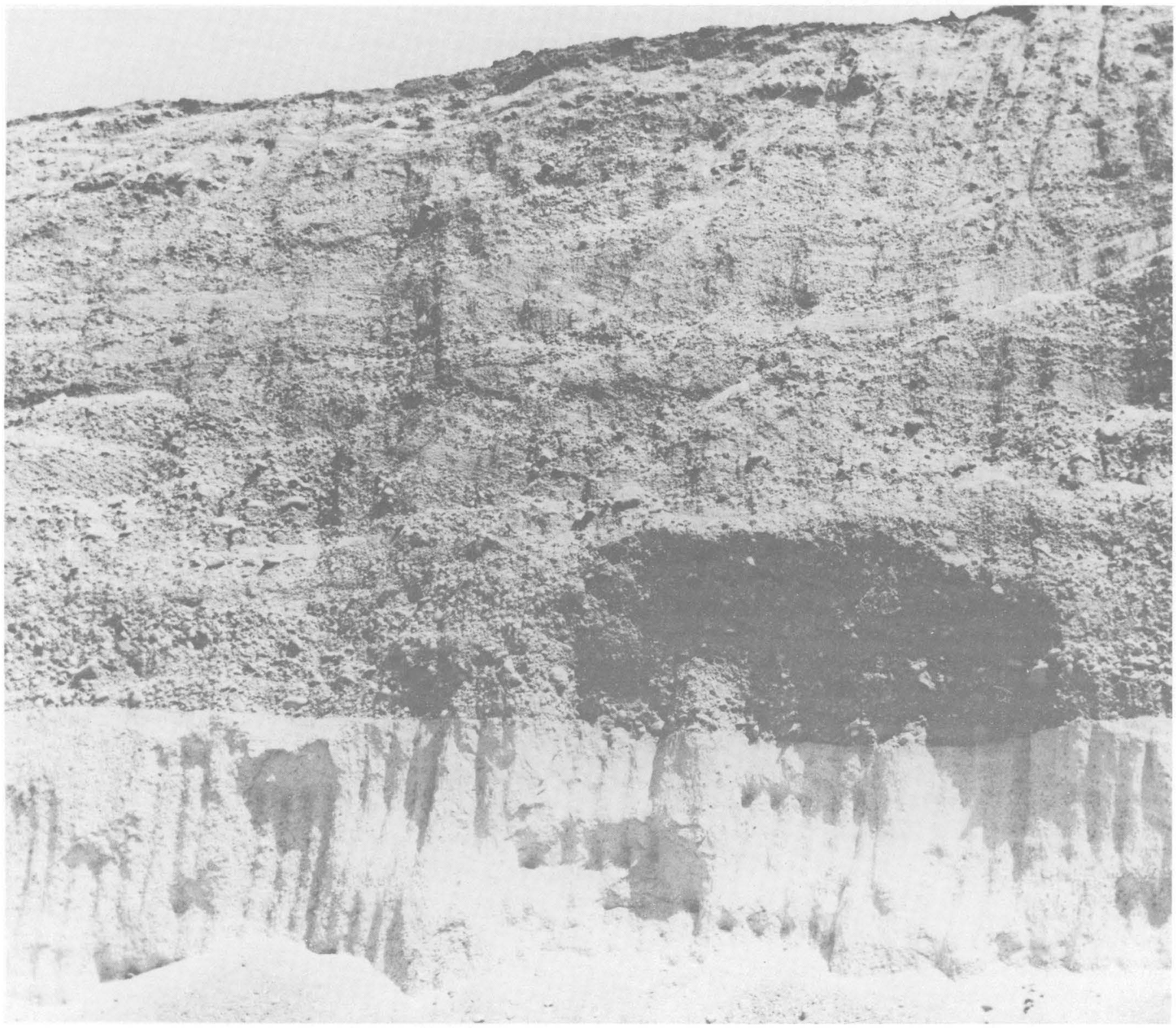

Figure 22.- Pebbly sandstone of the La Habra Formation, unconformably overlain by older alluvium. View south of wall of gravel pit $1 \mathrm{~km}$ west of Yorba Linda Reservoir. Cut is about $12 \mathrm{~m}$ high. 
this well the upper member of the Fernando Formation reappears below the unconformity (structure section $E$-L, pl. 2). South and east of the Shoreline Oil Co. well, Pinkerton No. 1, rocks that are questionably assigned to the La Habra Formation rest unconformably on older rocks that include the Topanga Formation, the undifferentiated Sespe and Vaqueros Formations, the Williams Formation, and the Holz Shale Member of the Ladd Formation, in addition to the upper member of the Fernando Formation (structure sections $L \cdot P, U \cdot V$, and $U \cdot W$, pl. 3 ).

About $6 \mathrm{~m}$ of the La Habra Formation is exposed be. neath stream-terrace deposits in the gravel pit at the north edge of the Orange quadrangle. There, the La Habra Formation is a massive, very friable, white conglomeratic sandstone. Individual grains of the sandstone are completely unsorted angular to subrounded quartz and feldspar clasts that are covered by a film of white clayey material. Dark minerals such as mica are almost completely absent. The individual sand grains range from fine- to granule size and local discontinuous lenses of pebble conglomerate are present. Most of the larger clasts are light-colored plutonic rocks, although a few subanglular fragments of greenish-gray sandy siltstone, similar in lithology to beds in the upper member of the Fernando Formation, are present. No fragments of siltstone were found in this sequence. At places bedding is suggested by concentrations of pebbles, but these are rather obscure and variable and may be indications of crossbedding. Well data on the lithologic character of the La Habra Formation south of the outcrop area are limited to electric logs, old driller's logs, and a few core samples. These indicate that the La Habra Formation consists of interbedded soft sandstone, conglomerate, and minor amounts of siltstone.

Cores from the Texas Co. well, Olive Community No. 1, the Standard Oil Co. well, Tustin No. 1, and the Shoreline Oil Co. well, Pinkerton No. 1, indicate that the La Habra Formation in that area consists of yellow clay, yellow clayey sandstone, gray siltstone, and friable conglomerate.

The La Habra Formation lacks fossils almost everywhere in the map area and is probably almost entirely nonmarine. Beneath the southwestern lowlands, however, at least one marine tongue is present, just a meter or so below its top, in Amerada Petroleum Corp. well, Irvine No. 63-1, at the southwest end of structure section $R-S$ ( $\mathrm{pl} .3$ ). Other marine tongues may be present still farther southwest, where the post-Miocene rocks of the subsurface cannot be subdivided on the basis of available data.

\section{PLEISTOCENE AND HOLOCENE SERIES TERRACE DEPOSITS}

Within the map area, terrace deposits include fluvial sediments that lie well above active stream courses and the modern floodplain. Some of the terrace deposits are structurally deformed, but most are nearly flat lying. Typically, they are weathered to various shades of reddish and yellowish brown and form steplike features along Santiago Creek and its main tributaries. The terrace deposits are subdivided into deformed alluvial deposits and older alluvium.

\section{DEFORMED ALLUVIAL DEPOSITS}

Alluvial deposits that have been conspicuously deformed occur at two places within the area mapped. One of these is on the south side of Burruel Ridge; the other caps the high part of Loma Ridge. The two widely separated deposits probably are not correlative.

On the south side of Burruel Ridge, a deformed alluvial deposit is similar to older alluvium along Santiago Creek, but its uphill edge, instead of being marked by a terrace riser, is bounded by a north-dipping fault, on which the La Vida Member of the Puente Formation is thrust over the younger unit. Here the deformed alluvial deposit is unconformable on the underlying Topanga Formation. Just below the base of the deformed deposit, the Topanga Formation dips as much as $60^{\circ}$ $\mathrm{N}$., and the contact dips $24^{\circ} \mathrm{N}$. and strikes N. $40^{\circ} \mathrm{W}$. The deformed alluvial material consists of an unsorted mixture of pebbles, cobbles, and boulders of many lithologic types in a gray and tan earthy clayey sandy matrix similar in appearance to material from weathered surfaces of the El Modeno Volcanics.

The upper contact of this deposit is a thrust fault, which strikes $\mathrm{N}$. $27^{\circ}$ E. and dips $42^{\circ} \mathrm{N}$. where best exposed; 2 to $10 \mathrm{~cm}$ of siltstone gouge is present along the fault. At the east end of this exposure the thrust fault has been dropped down a short distance by a northwest-trending normal fault. The maximum exposed thickness of the deposit is about $15 \mathrm{~m}$. The highest and oldest deposits assigned to the older alluvium of Santiago Creek bury the western end of the outcrop. The faulted deposit is similar to other terrace deposits in lithology and general appearance; its primary difference is in the amount of deformation.

The higher part of Loma Ridge has a relatively flat upper surface, and summit elevations increase southward. The elevation is $399 \mathrm{~m}$ in the western part of Irvine block $68 ; 6 \mathrm{~km}$ southeast, in block 117 , the summit elevation is $540 \mathrm{~m}$. In this block, deformed alluvial deposits of coarse sand and gravel cap Hills 1760 and 
1775. The perched gravel, which overlies the Puente Formation on these hills, is considered an erosional remnant of once widespread fluvial deposits. These folded deposits lie along the trough of a small northeast-trending syncline.

\section{OLDFR ALLUVIUM}

Deposits associated with the modern drainage system are present along both sides of the Santa Ana River and along Santiago Creek and many of its tributaries, including the lower parts of Blind Canyon, Fremont Canyon, Limestone Canyon, Silverado Canyon, and the west fork of Ladd Canyon. They are all of late Pleistocene age, although the youngest may be of Holocene age.

The older alluvium along Santiago Creek is locally well preserved (fig. 23) and has been subdivided on the basis of its relative altitude above the stream into four numbered units. East of Orange, the deposits of Santiago Creek merge with the younger alluvium of the coastal plain to the west and south, and an arbitrary contact between the two units is shown on the map.

Elsewhere in the map area no systematic division of the older alluvium could be made. Small isolated remnants of terrace deposits not now associated with the present drainage are found near the head of the west fork of Hall Canyon, along the crest of Loma Ridge on the boundary between Irvine blocks 117 and 118, and in the area adjacent to the mouth of Round Canyon at the south edge of the map area. These deposits apparently have not been deformed.

The older alluvium is variable in composition. It generally consists of a mixture of angular to rounded pebbles, cobbles, and boulders derived from older formations in a matrix of clayey red sand and silt. A local source for much of this material is indicated by the presence at some places of concentrations of calcareous siltstone fragments derived from the Puente Formation plus sandstone and siltstone blocks, as well as gray calcareous concretions, derived from the Upper Cretaceous and Tertiary formations. The maximum clast size is about $1 \mathrm{~m}$, and the average size is less than $0.3 \mathrm{~m}$. Some outcrops consist of earthy sandstone, and many individual beds are composed almost entirely of small siltstone fragments. Both the coarse- and fine-grained units locally show poorly developed crossbedding.

The color of the older alluvial material is generally yellowish to reddish brown, although gray outcrops are exposed in fresh cuts. In some outcrops the material is weak and crumbly and has been weathered and oxidized in places, whereas in other areas the material is relatively fresh and unweathered. These variations in weathering appear to be random and local rather than related to age or area of deposition.

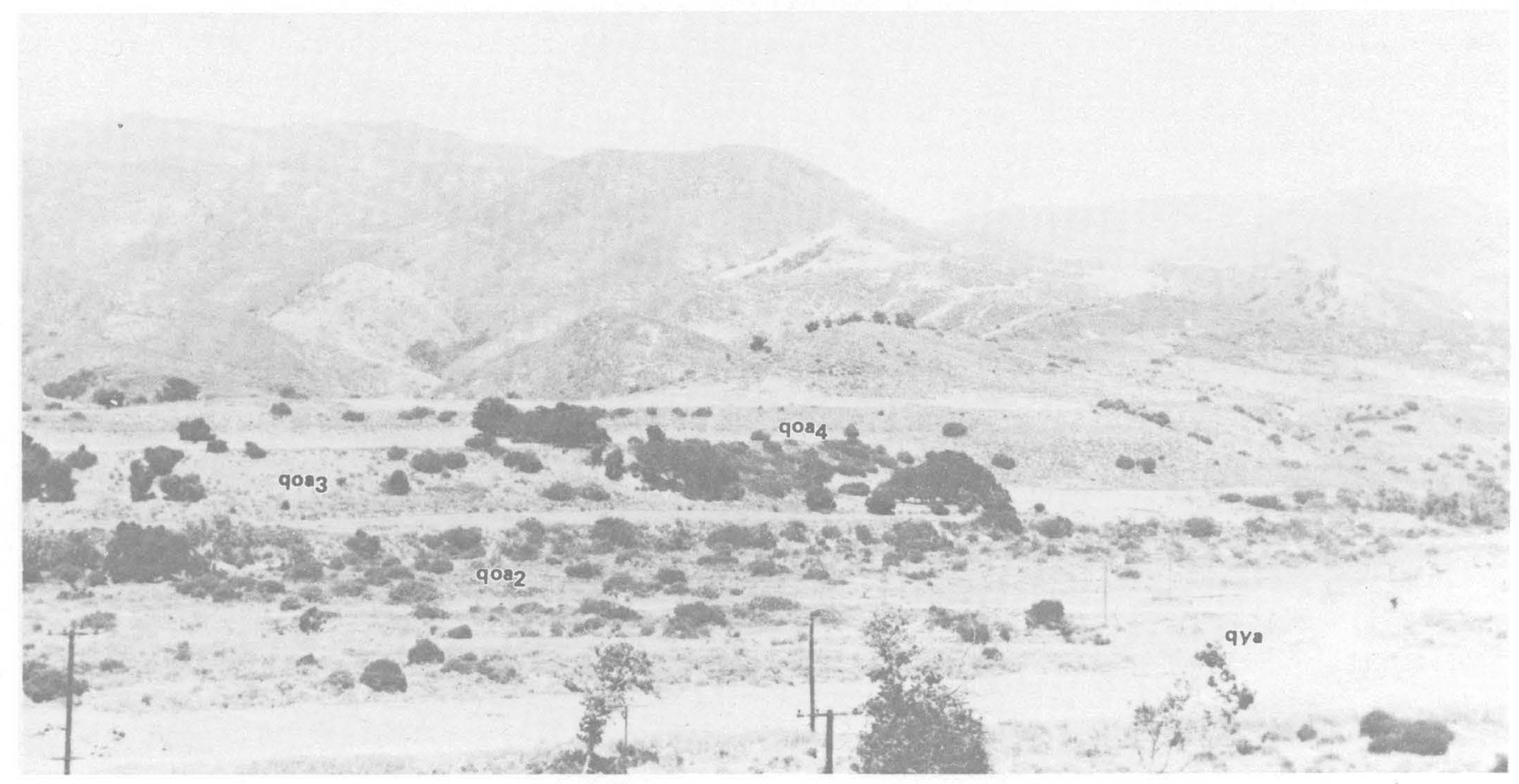

FIgURE 23.- Terraces and older alluvium north of junction of Santiago and Silverado Creeks. Qoa 2, 3, 4, older alluvium; Qya, younger alluvium. View northeast from Santiago Canyon Road $1 \mathrm{~km}$ west of intersection with Siiverado Canyon Road. 
The various isolated remains of older alluvium on terraces range in thickness from less than a meter to 60 m.

Fossils have not been found in the older alluvium within the map area, but elsewhere in the Los Angeles basin, equivalent beds have yielded numerous vertebrates of Pleistocene age (Miller, 1971).

\section{YOUNGER ALLUVIUM}

The younger alluvial deposits include material now being actively transported by streams and slightly older deposits of the same general character, upon which the present streams flow. Locally these deposits are incised as much as $6 \mathrm{~m}$ by stream action.

The southwestern part of the map area is covered by younger alluvium deposited by the two major streams, the Santa Ana River and Santiago Creek. Southeast of Tustin, small southwest-draining washes that head along the crest of Loma Ridge have contributed much material to this alluviated area. The coalescing of these and many other alluvial fans has formed the broad smooth surface which slopes away from the hills toward the Pacific Ocean southwest of the map area. This lowland area, about $80 \mathrm{~km}$ long and 25 to $30 \mathrm{~km}$ wide and having an area of approximately 2,000 square kilometers, is the central, sinking part of the Los Angeles basin. The southwestern margin of the basin is low, and the major streams have cut through it to the sea. For this reason the lowland was called a coastal plain by Mendenhall (1905, p. 11) and locally the Tustin Plain by Poland and Piper (1956).

No systematic study of the lithologic character and variation of the younger alluvial deposits was made for this report. With the exception of the through-flowing Santa Ana River, all the alluvium has been locally derived. It consists of interbedded and unconsolidated mud, sand, pebbly sand, and gravel. Fresh exposures are various shades of gray, depending upon the color of the local source rocks and the amount of washing by stream action. Younger alluvium along stream courses in the higher parts of the Santa Ana Mountains consists mainly of pebbles, cobbles, and boulders derived from the Bedford Canyon Formation, the Santiago Peak Volcanics, and material reworked from conglomerate in formations of Tertiary age. Along the south side of Loma Ridge, the younger alluvium contains abundant subangular fragments of white siltstone derived from the La Vida Member of the Puente Formation. The clasts size decreases rapidly downstream; the material distributed on the gently sloping Tustin Plain in the western and southern part of the area consists of clayey sand and silt. These surface sediments have been weathered to form gray sandy loam and dark-gray to black clayey sandy gumbo soils.
The Santa Ana River transports material derived from the eastern Puente Hills, the northern slope of the Santa Ana Mountains, and areas of alluvium and basement rock to the east and north. The alluviated river valley varies in width from about $1 \mathrm{~km}$ where it enters the area from the northeast to about $3 \mathrm{~km}$ between the towns of Olive and Atwood, where it merges with the Tustin Plain. Surface exposures of these younger alluvial deposits are medium- to coarsegrained feldspathic sand that contain variable amounts of clay and silt, which, when dry, bind the sand grains together. Core drilling was done in the Santa Ana River channel in order to evaluate possible dam sites, and the results of this work have been published by Post (1928, p. 261-264). One set of coreholes was drilled across the river channel parallel to structure section $\mathrm{H} \cdot \mathrm{O}$ ( pl. 3) and indicated an alternating sequence of sand, gravel, and boulders as large as $25 \mathrm{~cm}$. Bedrock was reached at depths of $25 \mathrm{~m}$ below the surface.

Little is known about the subsurface lithologic character of the younger alluvium that covers the older rocks in the southwestern part of the area. All data must be obtained from well records, but most wells drilled for oil penetrate alluvium without coring or sampling, and electric logs are run only after surface casing has been set, generally below the base of the alluvium. Where ditch samples and electric logs are available they indicate an alternating and lenticular sequence of silt, sand, and gravel. Many water wells drilled in the area penetrate the younger alluvium, and geologic data of varying quality are available from them. Much of this material has been published by Mendenhall (1905), Eckis (1934), Piper (1953), Poland and Piper (1956), and Singer (1973). These reports deal primarily with the water-bearing characteristics of the younger rocks, and stratigraphic and lithologic information is generalized.

The thickness of the younger alluvium ranges from zero to a known maximum of about $140 \mathrm{~m}$ in the Amerada Petroleum Corporation well, Irvine No. 63-1, in Irvine Block 63. The thickness may be much greater in the central part of the Los Angeles basin.

\section{STRUCTURE}

The area covered by the geologic map ( pl. 1) is the broad southwestern flank of a very large northwest plunging anticline. It can be divided into two main structural parts: the small area northeast of the Whittier and Elsinore faults, which is structurally related to the eastern Puente Hills area (Durham and Yerkes, 1964), and the main mass of the mountains southwest of these faults. The core of the southwest-tilted main block, at its northeastern edge is a narrow, northwesttrending belt of Mesozoic basement rocks. 
The principal local complexity is the faulted westward-plunging anticline that makes up the northwestern part of the range. Here, no basement rocks are exposed, but the Upper Cretaceous and Cenozoic rocks dip northwest in the northernmost part of the range and south or southwest in the area southeast of Irvine Park (lower Santiago Creek). The anticlinal axis trends through the lower part of Black Star Canyon, the mouth of Blind Canyon, and thence westward across Santiago Creek in the vicinity of the National Securities Oil Co. well, Irvine 1, until it apparently terminates against the El Modeno fault east of El Modeno.

\section{REGIONAL STRUCTURAL PATTERN} NORTHEAST OF WHITTIER-ELSINORE FAULT

The Whittier-Elsinore fault transects the northeasternmost corner of the map area and separates the Upper Jurassic(?) and Lower(?) Cretaceous Santiago Peak Volcanics on the south from Upper Cretaceous and younger sedimentary rocks on the north. The area north of this fault is structurally part of the eastern Puente Hills (Durham and Yerkes, 1964); it is characterized by west-trending faults, vertical and overturned strata of similar trend, and at least one tight overturned fold.

The Whittier fault trends approximately S. $80^{\circ} \mathrm{E}$. from its intersection with the Santa Ana River to the small north-trending cross fault in Fresno Canyon, which offsets the main fault about $200 \mathrm{~m}$ to the south. Southeast of this cross fault, the trend of the main fault varies around S. $55^{\circ} \mathrm{E}$. It is commonly called the Elsinore fault, and it makes the northeastern scarp of the Santa Ana Mountains. Nowhere along the Whittier-Elsinore fault zone in the map area could the dip of a fault plane be measured, but poorly exposed gouge zones in the bottoms of several steep gullies suggest that the zone in this area is either vertical or dips steeply to the south or southwest.

The Holz Shale Member of the Upper Cretaceous Ladd Formation has not been recognized outside of the Santa Ana Mountains-San Joaquin Hills area. Its presence north of the Whittier fault and in the deep and narrow Chino-Corona trough (Gaede, 1969) with similar lithology, thickness, and fossil assemblage suggests that little strike slip has occurred on this segment of the Whittier-Elsinore-Chino fault complex since middle Cretaceous time, an interpretation also suggested by the inferred distribution of Paleocene strata (Yerkes and others, 1965, fig. 7). The known petrologic, stratigraphic, and structural features of the Upper Cretaceous and Cenozoic strata in the Santa Ana Mountains, the Puente Hills, and eastern Los Angeles basin seem to be consistent with this conclusion. The lithology and shape of the sandstone lens in the Soquel Member of the upper Miocene Puente Formation, from the conglomerate at its head near Pomona to the sandstone toe near Anaheim, are especially significant. The only large break in the Soquel is at the Whittier fault, and the displacement here must be almost entirely dip slip.

\section{SOUTHWEST OF WHITTIER-ELSINORE FAULT ZONE}

South and west of the Whittier-Elsinore fault the rocks are complexly faulted and folded and are divided arbitrarily into three parts: the exposed structures, the buried structures south of the El Modeno fault, and the buried structures north of the El Modeno fault.

\section{EXPOSED STRUCTURES FAULTS}

Numerous faults with various trends and displacement cut the rocks that crop out south and west of the Whittier-Elsinore fault. In general these faults trend either northwest or northeast, although some faults tend west and north. Many of the north- or northwesttrending faults are longer and have greater apparent vertical separations. Curved and sinuous fault traces are common, and several of these change strike as much as $90^{\circ}$ along their length. About 260 separate fault traces are shown on plate 1 , but many other small ones have not been mapped. Of the faults mapped, 160 show stratigraphic separations that are down on the west, and 100 show separations that are down on the east. The amount of movement down on the west is of greater overall magnitude.

The oldest dated fault in the mapped area is exposed for a thousand meters or so along the crest of the Santa Ana Mountains, in the vicinity of the intersection of Black Star Canyon-Skyline Drive and the Main Divide Motorway. It is younger than the Santiago Peak Volcanics and older than the Ladd Formation. Near structure section $R \cdot S$ ( pl. 3 ), the fault dips $20^{\circ}$ northeast and is marked by a gouge zone several centimeters wide. Here the Baker Canyon Conglomerate Member of the Ladd Formation is nearly horizontal and lies unconformably across the Bedford Canyon Formation, the Santiago Peak Volcanics, and the gently northeast dipping thrust(?) fault separating them.

The Irvine Lake dam and spillway on Santiago Creek, south of the mouth of Fremont Canyon, are constructed on fault blocks of Upper Cretaceous and lower Tertiary rocks. The principal faults are shown on structure section $L-Q$ (pl. 3 ) just east of its intersection with structure section $A \cdot K$ (pl. 2). The Baker Canyon Conglomerate and Holz Shale Members of the Ladd Formation are upfaulted in a north-trending slice that extends from 600 to $2,000 \mathrm{~m}$ north from the spillway. The apparent downthrow on the two faults east of Blind Canyon is 
about $760 \mathrm{~m}$ on the western one and about $450 \mathrm{~m}$ on the eastern one.

Near the mouth of Bee Canyon an uplifted block of the Williams and Silverado Formations is bounded on at least three sides by normal faults. Northwest of Bee Canyon the largest fault strikes about N. $60^{\circ} \mathrm{W}$. and separates the undifferentiated Sespe and Vaqueros and. Santiago Formations on the north from the Williams Formation on the south. This fault appears to turn southward beneath the alluvium of Bee Canyon and separates the Williams Formation on the west from the Soquel Member of the Puente Formation and the Oso Member of the Capistrano Formation on the east. The fault dips $55^{\circ} \mathrm{E}$. in an irrigation ditch $330 \mathrm{~m}$ northeast of Tomato Spring. A concealed northeast-trending branch of this fault continues up Bee Canyon beneath the alluvium to separate the Santiago Formation on the northwest from the upper part of the undifferentiated Sespe and Vaqueros Formations on the southeast. A normal fault that strikes about N. $20^{\circ}$ E. and dips $55^{\circ}$ W. bounds this block of the Santiago on the west. This fault continues north to Limestone Canyon and displaces the Topanga and Puente Formations on Loma Ridge. Structure section $U-W(\mathrm{pl} .3)$ indicates a stratigraphic separation of about $500 \mathrm{~m}$ for this fault near its south end. Where the undifferentiated Sespe and Vaqueros are faulted against the Williams, the stratigraphic separation on the main fault could be as much as $800 \mathrm{~m}$. The displacement on the southtrending part of the main fault in the Lambert Reservoir area cannot be estimated because of lack of data on the thickness of the Silverado Formation exposed on the east. Data from the Shell Oil Co., Irvine core holes 2 and 5 , indicate that a structural high is present in that area, and structure section $T-X$ (pl. 3) suggests a downdrop of about $300 \mathrm{~m}$ east of the main fault.

The longest continuous fault trace is that of the El Modeno fault. It extends about $19 \mathrm{~km}$ from Little Joaquin Valley at the southeast to the Olive oil field at the northwest. Although concealed beneath Quaternary deposits along much of its length, its continuity is established by exposures and subsurface information.

The El Modeno fault has been recognized in the subsurface for a distance of about $21 \mathrm{~km}$ northwest of the map area (Yerkes and others, 1965 fig. 3). As early as 1924, Ferguson and Willis (1924, p. 578) published a small-scale map of the Los Angleles basin that showed a similar fault continuing southeast along the course of Santiago Creek and a more southerly trending branch that approximates the surface trace of the El Modeno fault in the area south of Santiago Creek.

Between Little Joaquin Valley and Santiago Creek, the El Modeno fault is exposed discontinuously, the fault trace is sinuous, and its trend averages about $\mathrm{N}$. $15^{\circ} \mathrm{W}$. On this segment the surface trace of the fault indicates a westward dip. In the Little Joaquin Valley area structure section $R-S$ (pl. 3) indicates a downthrow on the west of about $300 \mathrm{~m} ; 2 \mathrm{~km}$ to the north, structure section $L-Q$ (pl. 3 ) shows a downthrow to the west of about $400 \mathrm{~m}$.

The only exposure of the fault northwest of Santiago Creek is $890 \mathrm{~m}$ east of the Texas Co. well, Ragan (NCT-1) No. 1, where the Topanga Formation on the southwest is in contact with the undifferentiated Sespe and Vaqueros Formations on the northeast. A fault contact between the Santiago Formation, or possibly the Silverado Formation, and the Williams Formation is believed to be present in Ragan (NCT-1) No. 1 at a depth of about $1,415 \mathrm{~m}$. This contact correlates with the El Modeno fault; the indicated dip is about $70^{\circ}$ to the southwest. Structure section $M-F(\mathrm{pl} .2)$, drawn through the McKee Oil Co. well, Kokx Comm. 8-1, indicates a downthrow to the south of about $550 \mathrm{~m}$. The stratigraphic sequence in the Kokx well is believed to be normal and to be thinned by unconformities rather than by faulting, which would require a dip steeper than $70^{\circ}$ for the El Modeno fault. The youngest strata cut by the fault in this area are referred to the La Habra Formation of late Pleistocene age.

The Union Oil Co. well, Olive Comm. 4-1, southwest of the town of Olive drilled through the El Modeno fault at a depth of about $1,270 \mathrm{~m}$; it passed from the El Modeno Volcanics into the undifferentiated Sespe and Vaqueros Formations, and the Topanga Formation is faulted out. Structure section $E-L$ (pl. 2) indicates a stratigraphic separation of about $340 \mathrm{~m}$ in this area. The location and throw of the El Modeno fault are not precisely known west-northwest of this well.

In the southern foothills of the Santa Ana Mountains, between Little Joaquin Valley and the Peters Canyon reservoir, a horst of the undifferentiated Sespe and Vaqueros and Santiago Formations is bounded on the west by the El Modeno fault and on the east by a nearly parallel fault. The stratigraphic separation is about 460 $\mathrm{m}$ on the east side of the horst and $600 \mathrm{~m}$ on the west side, as shown by structure section $L-Q$ (pl. 3 ).

Along the southwest slope of Loma Ridge east of the horst, the La Vida Member of the Puente Formation rests unconformably on the undifferentiated Sespe and Vaqueros Formations. In the area between the head of Little Joaquin Valley and the head of Rattlesnake Canyon to the east, a group of northeast-trending faults cut the undifferentiated Sespe and Vaqueros but can be traced for only short distances into the overlying La Vida Member. In several of the individual fault blocks, the undifferentiated Sespe and Vaqueros cannot be matched across faults, which suggests greater displacements in these pre-late Miocene rocks. Some of 
these faults that cut the Puente Formation may have been active before the deposition of the La Vida, for only relatively small post-Puente movement is evident.

In the northwestern Santa Ana Mountains, faults commonly show greater displacement in the Cretaceous and lower Tertiary rocks than in the middle Miocene and younger rocks. The evidence suggests repeated movements on old faults.

$$
\text { FOLDS }
$$

The whole Santa Ana Range is a large northwesttrending asymmetric anticline whose northeastern limb is dropped down along the Elsinore fault and whose north-plunging nose is cut off by downfaulting on the Whittier fault zone. The broad and undulating, complexly faulted southwest limb makes up most of the mountains. It is divisible structurally into two rather vague folds, the major west-trending anticline with an axis extending west from Black Star Canyon through Irvine Park to the El Modeno fault, and a northwesttrending syncline centered on Loma Ridge between upper Santiago Creek and Peters Canyon reservoir.

The northeast limb of the syncline that underlies Loma Ridge has relatively gentle dips and is uncomplicated by major faults. The southwest limb is steeper and is complicated by local folds and by the structurally high fault blocks in Little Joaquin Valley and the Bee Canyon area (structure sections $R \cdot S, U \cdot V, U \cdot W, \mathrm{pl}$. 3).

Minor anticlines and synclines are imposed on the main folds of the northwestern Santa Ana Mountains and are widely scattered in the area. The most important of these is the anticline exposed at the northern edge of the map area, on which the Kraemer oil field is located. The axis of this asymmetrical fold trends about N. $55^{\circ}$ E.; dips are less than $45^{\circ}$ on the northwest flank and greater than $45^{\circ}$ on the southeast flank. Three kilometers east of the Kraemer oil field, two small anticlines and two small synclines are partially exposed ( structure section $H \cdot O$, pl. 3 ). The axis of the northernmost anticline trends about N. $45^{\circ} \mathrm{E}$.

Several small folds are exposed on the western part of Burruel Ridge; they apparently plunge westward beneath the alluvium of the Santa Ana River. The Richfield Oil Corp. well, Peralta Hills No. 1, was drilled on the surface trace of a westward-plunging anticline offset by a small northwest-trending fault. A small shallow syncline is present directly to the south (structure section $A \cdot K$, pl. 2). Two opposing dips in strata of the lower member of the Fernando Formation just south of the Riverside Freeway near Peralta Hills mark the eastern limit of a west-plunging anticline that may continue into the Olive oil field.

At the west end of Burruel Ridge the A. A. Carrey well, Bixby-Nohl No. 1, was drilled on the surface trace of a small northwest-plunging anticline (structure section $M \cdot F$, pl. 2). Sharp chevron folds in the lower member of the Fernando Formation on the northwest side of the Riverside Freeway are probably part of this structure but cannot be shown at the scale of the geologic map. A small syncline to the south has a more westerly trend and plunges westward beneath the alluvium south of the town of Olive (structure section $E \cdot L$, pl. 2).

Near the head of Fremont Canyon in the northeastern part of the map area a small southwest-plunging anticline exposes the Holz Shale Member of the Ladd Formation at its core (structure section $H-O$, pl. 3 ). These minor folds have developed on the north limb of the main west-trending high of the northwestern Santa Ana Mountains.

A small southeast-plunging anticline is exposed in the Silverado and Santiago Formations $1 \mathrm{~km}$ northwest of Irvine Lake. Its position in relation to the south limb of the northwestern Santa Ana Mountains high is shown on structure section $R \cdot S$ (pl. 3 ).

South of Loma Ridge a well-developed anticline ex. tends from Bee Canyon eastward across Round Canyon. This fold trends about S. $75^{\circ} \mathrm{E}$. A syncline to the south trends about N. $60^{\circ} \mathrm{W}$. near Bee Canyon but plunges southward through an isolated outcrop of the La Vida Member of the Puente Formation and terminates abruptly against a west-trending normal fault.

Two small folds are exposed in the upfaulted block of undifferentiated Willams Formation of the Bee Canyon area. The northernmost of these is an anticline that trends about $\mathrm{N} .60^{\circ} \mathrm{W}$. near Bee Canyon (structure section $U \cdot W, \mathrm{pl} .3$ ). A syncline a short distance to the south has a curved trace but is subparallel to the anti cline. Both folds terminate against a fault on the east and appear to die out westward.

The Texas Co: well, Irvine (NCT-2) No. 1, in Little Joaquin Valley was drilled on a small anticline northeast of the El Modeno fault (structure section $R-S$, pl. 3 ). this fold strikes about N. $40^{\circ} \mathrm{W}$., and both ends appear to terminate against the fault.

\section{SUBSURFACE STRUCTURES SOUTH OF EL MODENO FAULT}

From the El Modeno fault southward to the vicinity of Orange the general pattern of the subsurface structure is fairly well documented by well records. The well density, however, is not sufficient to reveal small faults and folds. South and southeast of Tustin the wells are so widely separated and the stratigraphic section so variable that only broad structural features are discernible.

FAULTS

Only the larger faults exposed along the southwestern margin of the Santa Ana Mountains in the Bee Canyon 
area are traceable beneath the alluvium. It is believed that the faults that bound this block of Upper Cretaceous strata must extend southwest for some distance, and the presumed relations are shown on structure section $T \cdot X(\mathrm{pl} .3)$.

\section{FOLDS}

The main subsurface fold south of the El Modeno fault is the Anaheim nose, a broad, gently northwestplunging anticline, discussed in detail by Yerkes and others $(1965$, p. A48, A49). This structural feature can be recognized as far west as the vicinity of Buena Park, about $14 \mathrm{~km}$ northwest of the map area. Along the crest of the Anaheim nose, relatively undeformed Pliocene sedimentary rocks rest unconformably on middle Miocene and older sedimentary rocks. The upper Miocene Puente Formation laps out against the flanks of the structure and has been recognized on top of the structure only in its northwestern part (see Yerkes and others, 1965 , structure section $E-F$, pl. 4 ).

The gentle northern flank of the Anaheim nose is shown on structure section $E-L$ ( pl. 2). The axis of the structure is presumably near the Shoreline Oil Co. well, Pinkerton No. 1, although no subsurface data for precise location are available on the area directly to the south. In this well the upper member of the Fernando Formation rests unconformably on the undifferentiated Sespe and Vaqueros Formations. The older strata dip northward, and successively younger rocks are present beneath the unconformity in the area to the north. Many unconformities are associated with the growth of the Anaheim nose in this area. The oldest one known is at the base of the Puente Formation. This middle Miocene deformation is widespread throughout the Los Angeles basin (Barbat, 1958, p. 39-40; Yerkes and others, 1965, pl. 2). Local unconformities associated with the Anaheim nose include those at the base of the lower member of the Fernando Formation, at the base of the upper member, and at the base of the La Habra Formation, indicating continuing deformation since the middle Miocene.

Sparse well data in the area southeast of Tustin suggest that the Anaheim nose may extend toward the structural high of Upper Cretaceous strata in the vicinity of Bee Canyon. The Amerada Petroleum Corp. well, Irvine No. 63-1 (structure section $R \cdot S$, pl. 3), passed directly from the Puente Formation into the Williams Formation at a depth of $1,080 \mathrm{~m}$. The West American Oil Co., well Irvine No. $1,2.7 \mathrm{~km}$ to the northeast, penetrated the top of the Williams Formation at a depth of about $905 \mathrm{~m}$ and continued in sparsely fossiliferous Upper Cretaceous rocks to about $1,720 \mathrm{~m}$, where it penetrated rocks questionably correlated with the Bedford Canyon Formation or the Santiago Peak
Volcanics. No data are available on the age of the rocks above the Williams Formation, but the thick sequence of lower Tertiary rocks exposed $2 \mathrm{~km}$ to the northeast suggests that some of these rocks are present in this well. However, erosion of at least part of the lower Tertiary sequence in the area to the south is shown by the unconformity at the base of the Puente Formation. Strata of the undifferentiated Sespe and Vaqueros Formations are present southeast of the Amerada well (structure section $T \cdot X$, pl. 3 ), and in the Shell Oil Co. well, Irvine Corehole No. 4 , they rest unconformably on the Williams Formation. This is the only area in the northwestern Santa Ana Mountains where this unconformity has been found. The repeated unconformities indicate the significance of the Anaheim nose, and together with Bee Canyon high, the nose marks an important structural trend.

\section{SUBSURFACE STRUCTURES NORTH OF THE EL MODENO FAULT FAULTS}

No faults of large magnitude are known to be present in the subsurface north of the El Modeno fault. Gardiner (1943, p. 359) indicated east-northeast-trending faults on the south side of the Richfield oil field, and Saunders (1958, p. 150) showed north-and easttrending faults in the Olive oil field. The anomalously thick section of the lower member of the Fernando Formation in the Texas Co. wells, Dowling No. 1 and No. 2, and Kraemer No. 1, suggests the presence of a west- or north-trending fault in these wells.

\section{FOLDS}

The largest fold in the subsurface north of the El Modeno fault is a west-trending west-plunging syncline that can be recognized from southeast of the Kraemer oil field to the west edge of the map area north of the present channel of the Santa Ana River. North of this syncline the structure rises rapidly into the Kraemer and Richfield anticlines, both the sites of oil fields. On the south flank of the Richfield oil field a small subsidiary syncline and anticline trend N. $70-80^{\circ} \mathrm{E}$. ( structure section $A \cdot K, \mathrm{pl} .2$ ).

South of the syncline that underlies the Santa Ana River, a west-plunging anticlinal axis passes through the Richfield Oil Corp. well, Hamrick-Olive No. 1 (structure section $E \cdot L$, pl. 2 ), and continues westward to the Olive oil field. a smaller, parallel syncline south of the town of Olive plunges westward from the outcrop at the west end of Burruel Ridge.

Fold axes in the late Miocene and younger rocks have a westward or slightly southwestward trend in the area north of the El Modeno fault, whereas south of the 
fault the main structural feature, the Anaheim nose, trends northwestward.

Uplift of the Anaheim nose began during middle Miocene time, and the distribution of the Puente Formation sandstone bodies indicates that the growing fold acted as a barrier to the sand that was carried in from the north and east. These sandstone bodies were deposited in a northwest-trending trough or basin the axis of which lies athwart the axis of the Santa Ana River syncline. Northeastward migration of the trough during late Miocene time is indicated by the progressive shifting of the maximum thickness lines of younger and younger sand units in that direction. In this area, accentuation of northwest-trending folds apparently continued at least to the end of the Miocene. The more westerly trending folds are much younger.

\section{SUMMARY AND REGIONAL INTERPRETATIONS}

The structure of the northern Santa Ana Mountains is dominated by (1) the broad north-plunging anticline that underlies the main mass of the mountains and is truncated at the northeast by the Whittier fault, (2) the northwest-trending anticline that underlies the southwest flank and plunges northwest beneath the Los Angeles basin as the Anaheim nose, and (3) numerous north- to northwest-trending, down-to-the-west normal faults that cut the folds into numerous blocks (Yerkes and others, 1965 , figs. 2,3 ). The faults commonly show evidence of repeated movement, and the longest one (El Modeno fault) cuts strata of late Pleistocene age.

The geologic coherence of the Santa Ana Mountains and adjoining parts of the Peninsular Ranges province - San Joaquin Hills to the south amd southwest, Los Angeles basin to the west, Puente Hills to the north, and Perris Block to the east-has been established (Durham and Yerkes, 1964; Yerkes and other, 1965: Vedder and others, 1957; Vedder, 1975; this report). Thus, interpretations based on geology of the Santa Ana Mountains have regional significance:

(1) The unconformity separating the basement and superjacent sedimentary rocks represent major tectonic and erosional events sometime between Late Jurassic and Late Cretaceous time (Tithonian(?) to lower Turonian).

(2) Exposed Upper Cretaceous and lower Tertiary sedimentary rocks provide a stratigraphic reference section for the sparsely drilled pre-Miocene subsurface sequence beneath the entire eastern Los Angeles basin.

(3) Southwestward tilt of the mountain block in Late Cretaceous and early Cenozoic time is recorded by the northeastward transgression of the Paleocene Silverado Formation onto successively older members of the
Upper Cretaceous sequence and thence onto basement rocks. data from adjoining parts of the Peninsular Ranges province show that to the north and east of the mapped area Paleocene, Eocene, Oligocene(?) and Miocene strata successively become the oldest sedimentary rocks to rest on the basement surface; that surface is presumed to be an early Cenozoic relic.

(4) The early Cenozoic erosion surface persisted for a considerable time in a moist tropical or subtropical climate, as indicated by the Paleocene Claymont Clay Bed and associated strata.

(5) Provenance of lower Tertiary conglomerates, including those of early Miocene age (undifferentiated Sespe and Vaqueros Formations), contrasts with that of later deposits. Supplies from distant sources ceased and were replaced with material from nearby basement sources in middle Miocene time.

(6) The southwestward tilt of the mountain mass was accentuated during Oligocene and early Miocene time and was followed in middle Miocene time by relative depression of the Los Angeles basin. This subsidence still continues in the central part of the basin.

(7) Continuing post-middle Miocene deformation produced pronounced erosional unconformities in upper Miocene, Pliocene, and upper Pleistocene units along and across exposed and buried folds (Yerkes and others, 1965 , structure section $C \cdot D$ and $E \cdot F \cdot G, \mathrm{pl} .4)$.

\section{REFERENCES CITED}

Allison, E. C., 1955, Middle Cretaceous Gastropoda from Punta China, Baja California, Mexico: Jour. Paleontology, v. 29, p. 400-432.

Barbat, W. F., 1958, The Los Angeles Basin area, California, in A guide to the geology and oil fields of the Los Angeles and Ventura regions: Am. Assoc. Petroleum Geologists, Ann. Mtg., March 1958, Proc., p. 37.49.

Bellemin, G. W., and Merriam, R. H., 1958, Petrology and origin of the Poway conglomerate, San Diego County, California: Geol. Soc. America Bull., v. 69, p. 199-220.

Blake, W. P., 1856, Notice of remarkable strata containing the remains of Infusoria and Polythalmia in the Tertiary formation of Monterey, California: Acad. Nat. Sci. Philadelphia Proc., v. 7 , p. $328 \cdot 331$.

Bowers, Stephen, 1890, Orange County: California State Mining Bur. Ann. Rept. no. 10, p. 399-409.

Bramlette, M. N., 1946, The Monterey formation of California and the origin of its siliceous rocks: U. S. Geol. Survey Prof. Paper $212,57 \mathrm{p}$

Buckley, C. P., Condra, C. A., and Cooper, J. D., 1975, The Jurassic flysch of the Santa Ana Mountains [abs.]; Geol. Soc. America Cordilleran Section, Abs. with programs, p. 256.436.

Burchfiel, B. M., and Mulryan, Henry, 1940, Flint clays and flint-clay refractories of southern California: Am. Ceramic Soc. Bull., v. 19 , no. 5 , p. $161-163$.

Bushee, Jonathan, Holden, John, Geyer, Barbara, Gastil, Gordon, 1963, Lead-alpha dates for some basement rocks of southern California: Geol. Soc. America Bull., v. 74, p. 803-806.

Colburn, I. P., 1973, Stratigraphic relations of the southern Califor- 
nia Cretaceous strata, in Colburn, I. P., and Fritsche, A. E., Cretaceous stratigraphy of the Santa Monica Mountains and Simi Hills, southern California: Soc. Econ. Paleontologists and Mineralogists, Pacific Sec., Geological Guidebook for the 1973 Fall Field Trip, p. 45-73.

Colburn, I. P., and Fritsche, A. E., 1973, Cretaceous stratigraphy of the Santa Monica Mountains and Simi Hills, southern California: Soc. Econ. Paleontologists and Mineralogists, Pacific Sec., Geological Guidebook for the 1973 Fall Field Trip, $93 \mathrm{p}$.

Cooper, J. G., 1888, Catalogue of California fossils: California State Mining Bur. Ann. Rept. no. 7, p. 221-308.

Daviess, S. N., and Woodford, A. O., 1949, Geology of the northwestern Puente Hills, Los Angeles County, California: U. S. Geol. Survey Oil and Gas Inv. Prelim. Map 83.

Davis, R. A., Jr., 1978, Paleocurrent analysis of the Upper Cretaceous, Paleocene, and Eocene strata, Santa Ana Mountains: Univ. of Southern California, M.A. thesis, 83 p.

Dibblee, T. W., Jr., 1950, Geology of southwestern Santa Barbara Co., Calif.: California Div. Mines Bull. 150, p. 22-23.

1966, Geology of the central Santa Ynez Mountains, Santa Barbara County, Calif.: Calif. Div. Mines and Geology Bull. $186,99 \mathrm{p}$.

Dickerson, R. E., 1914, The Martinez and Tejon Eocene and associated formations of the Santa Ana Mountains: California Univ. Pubs. Dept. Geology Bull., v. 8, p. 257-274.

Durham, D. L., and Yerkes, R. F., 1959, Geologic map of the eastern Puente Hills, Los Angeles Basin, California: U. S. Geol. Survey Oil and Gas Map OM-195, scale 1:24,000.

1964, Geology and oil resources of the eastern Puente Hills, sou thern California: U. S. Geol. Survey Prof. Paper 420-B, 62 p.

Durrell, Cordell, 1954, Geology of the Santa Monica Mountains, Los Angeles and Ventura Counties, Map Sheet 8 of Jahns, R. H., ed., Geology of southern California: California Div. Mines Bull. 170 , scale $1: 48,000$.

Eaton, G. P., 1958, Miocene volcanic activity in the Los Angeles basin [California ], in A guide to the geology and oil fields of the Los Angeles and Ventura regions: Am. Assoc. Petroleum Geologists, Ann. Mtg., March 1958, Proc., p. 55-58.

Eckis, Rollin, 1934, South coastal-basin investigation; Geology and ground-water storage capacity of valley fill: California Dept. Public Works, Water Resources Div. Bull. 45, 279 p.

Eldridge, G. H., and Arnold, Ralph, 1907, the Santa Clara valley, Puente Hills, and Los Angeles oil districts, southern California: U. S. Geol. Survey Bull. 309, 266 p.

English, W. A., 1926, Geology and oil resources of the Puente Hills region, southern California: U. S. Geol. Survey Bull. 768, 110 p.

Fairbanks, H. W., 1893, Geology of San Diego; also portions of Orange and San Bernardino Counties [California]: California State Mining Bur. Rept. 11, p. 76-120.

Ferguson, R. N., and Willis, C. G., 1924, Dynamics of oil-field structure in southern California: Am. Assoc. Petroleum Geologists Bull. v. 8 , no. p. $576-583$.

Fife, D. L., Minch, J. A., and Crampton, P. J., 1967, Late Jurassic age of the Santiago Peak Volcanics, California: Geol. Soc. America Bull., v. 78 , no. 2, p. 299-304, 5 figs.

Gaede, V. F., 1969, Prado-Corona oil field: California Oil Fields Summ. Operations, v. 55, p. 23-29.

Gardiner, C. M., 1943, Richfield area of the Richfield oil field [California]: California Div. Mines Bull. 118, p. 357-360.

Gastil, R. G., Phillips, R. P., and Allison, E. C., 1975, Reconnaissance geology of the State of Baja California: Geol. Soc. America Mem. 140, 170 p., with map.

Goodyear, W. A., 1888, Los Angeles County: California State Mining Bur. Ann. Rept. no. 8, p. 335-342.
Goudkoff, P. P., 1945, Stratigraphic relations of Upper Cretaceous in Great Valley, California: Am Assoc. Petroleum Geologists Bull. N. 29 , no. 7 , p. 956-1007.

Gray, C. H., Jr., 1961, Geology of the Corona South quadrangle and the Santa Ana Narrows area, Riverside, Orange, And San Bernardino Counties, California: California Div. Mines Bull. 178 , $119 \mathrm{p}$.

Hamlin, Homer, 1904, Water resources of the Salinas Valley, California: U. S. Geol. Survey Water-Supply Paper 89, 91 p.

Hanna, M. A., 1927, An Eocene invertebrate fauna from the La Jolla quadrangles, California: California Univ. Pubs., Dept. Geol. Sci. Bull., v. 16, p. 247-398.

Hertlein, L. G., and Grant, U. S., VI, 1939, Geology and oil possibilities of southwestern San Diego County, California: California Div. Mines Spec. Rept. 35, p. $57.58 \mathrm{~m}$

Hoots, H. W., 1931, Geology of the eastern part of the Santa Monica Mountains, Los Angeles, County, California: U. S. Geol. Survey Prof. Paper 165-C, $134 \mathrm{p}$.

Imlay, R. W., 1963, Jurassic fossils from southern California: Jour. Paleontology, v. 37, p. 97-107.

Ingle, J. C., Jr., 1967, Foraminiferal biofacies variation and the Miocene-Pliocene boundary in southern California: Bull. Am. Paleontology, v. 52, no. 236, p. 217-394.

1971, Paleoecologic and paleobathymetric history of the late Miocene-Pliocene Capistrano Formation, Dana Point area, Orange County, California, in Geologic guidebook, Newport Lagoon to San Clemente, Orange County, California: Soc. Econ. Paleontologists and Mineralogists, Pacific Sec., 88 p. 1972, Biostratigraphy and paleoecology of early Miocene through early Pleistocene benthonic and planktonic Foraminjfera, San Joaquin Hills, Newport Bay, Orange County, California, in The proceedings of the Pacific Coast Miocene biostratigraphic symposium: Soc. Econ. Paleontologists and Mineralogists, Pacific Sec., 47th Ann. Conv., p. 255-283.

Jones, D. L., Blake, M. C., and Rangin, Claude, 1976, The four Jurassic belts of northern California and their significance to the geology of southern California borderland, in Howell, D. G., ed., Aspects of the geologic history of the California conti. nental borderland: Am. Assoc. Petroleum Geologists, Pacific Sec., Misc. Pub. 24, p. 343-362.

Kennedy, M. P., and Moore, G. W., 1971, Stratigraphic relations of Upper Cretaceous and Eocene formations, San Diego coastal area, California: Am. Assoc. Petroleum Geologists Bull., v. 55, no. 5 , p. $709 \cdot 722$.

Mallory, V. S., 1959, Lower Tertiary biostratigraphy of the California Coast Ranges: Tusla, Okla., Am. Assoc. Petroleum Geologists, $416 \mathrm{p}$.

Kew, W. S. W., 1923, Geologic formations of a part of southern California and their correlation: Am. Assoc. Petroleum Geologists Bull., v. 7, no. 4, p. 411.420.

Kleinpell, R. N., 1938, Miocene stratigraphy of California: Tulsa, Okla., Am. Assoc. Petroleum Geologists, 450 p.

Lang, H. R., 1978, Late Cretaceous biostratigraphy of the southeast. ern Los Angeles basin: California Division of Oil and Gas, Spec. Rept. No. TR20, 15 p.

Larsen, E. S., 1948, Batholith and associated rocks of Corona, Elsinore, and San Luis Rey qudrangles, southern California: Geol. Soc. America Mem. 29, 182 p.

Listsyna, N. A., 1957, Corrosion of quartz in Meso-Cenozoic weathered mantle in northern Kazakhstan: Akad. Nauk SSSR, v. 114 , no. 4 , p. $862 \cdot 865$.

Matsumoto, Tatsuro, 1959-60, Upper Cretaceous ammonites of California: Kyushu Univ., Mem. Science, v. 8, p. 91-171; Spec. Vol. 1, p. 1-172; v. 2, p. 1.204. 
Mendenhall, W. C., 1905, Development of underground waters in the eastern coastal plain region of southern California: U. S. Geol. Survey Water-Supply and Irrigation Paper No. 137, 140 p.

Miller, W. E., 1971, Pleistocene vertebrates of the Los Angeles basin (exclusive of Rancho La Brea): Los angeles County Mus. Bull. Sci., no. 10,124 p.

Minch J. C., Gastil, Gordon, Fink, William, Robinson, John, and James, A. H., 1976, Geology of the Vizcaino Peninsula, in Howell, D. G., ed., Aspects of the geologic history of the California continental borderland: Am. Assoc. Petroleum Geologists, Pacific Sec., Misc. Pub. 24, p. 136-195.

Moran, A. I., 1976, allochthonous carbonate debris in Mesozoic flysch deposits in Santa Ana Mountains, California: Am Assoc Petroleum Geologists Bull., v. 60, no. 11, p. 2038-2043.

Nordstrom, C. E., 1070, Lusardi Formation: A post-batholithic Cretaceous conglomerate north of San Diego, California: Geol. Soc. America Bull., v. 81 , no. 2, p. 601-605.

Packard, E. L., 1916, Faunal studies in the Cretaceous of the Santa Ana Mountains of southern California: California Univ. Pubs., Dept. Geology Bull., v. 9, p. 137-159.

Peterson, G. L., 1971. Stratigraphy of the Poway area, southwestern California: San Diego Soc. Nat. History, v. 16, p. 225.236.

Piper, A. M., 1953, Native and contaminated ground waters in the Long Beach-Santa Ana area, California: U. S. Geol. Survey Water-Supply Paper 1136, $320 \mathrm{p}$.

Poland, J. F., and Piper, A. M., 1956, Ground water geology of the coastal zone, Long Beach-Santa Ana area, California: U. S. Geol. Survey Water-Supply Paper 1109, 162 p.

Poore, R. Z., 1976, Microfossil correlations of California lower Tertiary sections: A comparison : U. S. Geol. Survey Prof. Paper $743 \cdot \mathrm{F}, 8 \mathrm{p}$.

Popenoe, W. P., 1937, Upper Cretaceous Mollusca from southern California: Jour. Paleontology, v. 11, p. 379-402.

1941, The Trabuco and Baker conglomerates in the Santa Ana Mountains: Jour. Geology, v. 49, no. 7, p. $738 \cdot 752$.

1942, Upper Cretaceous formations and faunas of southern California: Am. Assoc. Petroleum Geologists Bull., v. 26, no. 2, p. $162 \cdot 187$.

Popenoe, W. P., Imlay, R. W., and Murphy, M, A., 1960, Correlation of the Cretaceous formations of the Pacific Coast (United States and northwestern Mexico): Geol. Soc. America Bull., v. 71 , no. 10 , p. $1491 \cdot 1540$.

Post, W. S., 1928, Santa Ana investigation, flood control and conservation: California Dept. Public Works, Div. Engineering and Irrigation Bull. 19 , p. 225-267.

Revelle, Roger, and Fairbridge, Rhodes, 1957, Carbonates and carbon dioxide, Chap. 10 of Hedgpeth, J. W., Ecology, v. 1 in Treatise on marine ecology and paleoecology: Geol. Soc. America Mem. 67, p. 239-295.

Richmond, J. F., 1952, Geology of Burruel Ridge, northwestern Santa Ana Mountains, California: California Div. Mines Spec. Rept. 21, 16 p.

Ross, C. S., and Kerr, P. F., 1931, The kaolin minerals: U. S. Geol. Survey Prof. Paper 165-E, p. 151-176.

Saunders, N. E., 1958, Olive oil field, in A guide to the geology and oil fields of the Los Angeles and Ventura regions: Am Assoc. Petroleum Geologists, Pacific Sec., Ann. Mtg., 1958, p. 149. 151.

Schoellhamer, J. E., Kinney, D. M., Yerkes, R, F., and Vedder, J. G., 1954, Geologic map of the northern Santa Ana Mountains, Orange and Riverside Counties, California: U. S. Geol. Survey Oil and Gas Inv. Map OM-154.

Schoellhamer J, E., and Vedder, J. G., 1975, selected core holes and wells drilled for oil, in Vedder, J. G., Revised geologic map, structure sections, and well table, San Joaquin Hills - Capis. trano area, California: U. S. Geol. Survey Open-File Rept. 75 .
552,5 sheets.

Schoellhamer, J. E., and Woodford, A. O., 1951, The floor of the Los Angeles Basin, Los Angeles, Orange, and San Bernardino Counties, California: U. S. Geol. Survey Oil and Gas Inv. Map OM-117, 2 sheets.

Shelton, J. S., 1955, Glendora volcanic rocks, Los Angeles Basin, California: Geol. Soc. America Bull., v. 66, no. 1, p. 45-89.

Silberling, N. J., Schoellhamer, J. E., Gray, C. H., Jr., and Imlay, R. W., 1961, Upper Jurassic fossils from Bedford Canyon formation, southern California: Am Assoc. Petroleum Geologists Bull., v. 45 , no. 10 , p. $1746 \cdot 1765$.

Singer, J. A., 1973, Geohydrology and artificial-recharge potential of the Irvine area, Orange County, California: U. S. Geol. Survey Open-File Rept. 5018-16, 41, p.

Smith, P. B., 1960, Foraminifera of the Monterey Shale and Puente Formation, Santa Ana Mountains and San Juan Capistrano area, California: U. S. Geol. Survey Prof. Paper 254-M, p. $463-495$.

Sutherland, J. C., 1935, Geologic investigation of the clays of Riverside and Orange Counties, southern California: California Jour. Mines and Geology, Rept. 31 of State Mineralogist.

Vedder, J. G., 1957, New stratigraphic names used on geologic map of the San Joaquin Hills-San Juan Capistrano area, Orange County, California in Vedder, J. G., Yerkes, R. F., and Schoellhamer, J. E., Geologic map of the San Joaquin Hills-San Juan Capistrano area Orange County, California: U. S. Geol. Oil and Gas Inv. Map OM-193.

1960, Previously unreported Pliocene Mollusca from the southeastern Los Angeles basin: U. S. Geol. Survey Prof Paper 400-B, p. B326-B328.

1972, Review of stratigraphic names and megafaunal correlation of Pliocene rocks along the southeast margin of the Los Angeles basin, California, in Stinemeyer, E H., ed., Pacific Coast Miocene Biostratigraphic Symposium: Soc. Econ. Paleontologists and Mineralogists, Pacific Sec., Bakersfield, Calif., March, 1972, p. 158-172.

1975, Revised geologic map, structure sections, and well table, San Joaquin Hills-Capistrano area, California: U. S. Geol. Survey Open-file Rept. 75.552, 5 sheets.

Vedder, J. G., Yerkes, R. F., and Schoellhamer, J. E., 1957, Geologic map of the San Joaquin Hills-San Juan Capistrano area, Orange County, California: U. S. Geol. Survey Oil and Gas Inv. Map OM-193, scale 1:24,000.

Watts, W. L., 1897, Oil and gas yielding formation of Los Angeles, Ventura, and Santa Barbara Counties: California State Mining Bur. Bull. 11, 94 p.

White, W. R., 1956, Pliocene and Miocene Foraminifera from the Capistrano Formation, Orange County, California: Jour. Paleontology, v. 30, p. 237-270.

1971, Biostratigraphy of the Capistrano Formation, Dana Point, California, in Berger F. W., ed., Geological guide book, Newport Lagoon to San Clemente, Orange County, California: Soc. Econ. Paleontologists and Mineralogists, Pacific Section, p. $50 \cdot 54$.

Whitney, J. D., 1865, Geological survey of California: Geology, v. 1, Report of progress and synopsis of field work from 1869 to $1864.498 \mathrm{p}$

Wissler, S. G., 1943, Stratigraphic formations [relations] of the producing zones of the Los Angeles basin oilfields: California Div. Mines Bull. 118, p. 209-234.

Woodford, A. O., 1925, The San Onofre breccia; Its nature and origin: California Univ. Pubs., Dept. Geol. Sci Bull., v. 15, no. 7, p. $159-280$.

Woodford, A. O., and Gander, Craig, 1977, Los Angeles erosion surface of middle Cretaceous age: Am. Assoc. Petroleum Geologists Bull., v. 61, no. 11, p. 1979-1990. 
Woodford, A. O., McCulloh, T. H., and Schoellhamer, J. E., 1973, Paleogeographic significance of metatuff boulders in middle Tertiary strata, Santa Ana Mountains, California: Geol. Soc. America Bull., v. 83, no. 11, p. 3433-3436.

Woodford, A. O., Welday, E. E., and Merriam, Richard, 1968, Siliceous tuff clasts in the upper Paleogene of southern California: Geol. American Bull., v. 79, p. 1461-1486.

Woodring, W. P., Bramlette, M. N., and Kew, W. S. W., 1946, Geology and paleontology of the Palos Verdes Hills, California: U. S. Geol. Survey Prof. Paper 207, 145 p.

Woodring, W. P., and Popenoe, W. P., 1945, Paleocene and Eocene stratigraphy of northwestern Santa Ana Mountains, Orange County, California: U. S. Geol. Survey Oil and Gas Inv. Prelim. Chart 12.

Woodring, W. P., Stewart, R. B., and Richards, R. W., 1940, Geology of the Kettleman Hills oil field, California; Stratigraphy, paleontology, and structure: U. S. Geol. Survey Prof. Paper $195,170 \mathrm{p}$.

Yerkes, R. F., 1957, Volcanic rocks of the El Modeno area, Orange County, California: U. S. Geol. Survey Prof. Paper 247-L, p. 313-334.

1972, Geology and oil resources of the western Puente Hills area, southern California: U. S. Geol. Survey Prof. Paper $420-\mathrm{C}, 63 \mathrm{p}$.

Yerkes, R. F., McCulloh, T. H., Schoellhamer, J. E., and Vedder, J. G., 1965, Geology of the Los Angeles basin, California - An introduction: U. S. Geol. Survey Prof. Paper 420-A, 57 p.

Zullo, V. A., and Durham, J. W., 1962, The echinoid genus Megapetalus Clark: Jour. Paleontology, v. 36 , no. 3, p. 524 528. 
SUPPLEMENTAL INFORMATION 
WELL LOCATIONS AND RELATED DATA

[Wildcat wells, core holes, and selected producing wells drilled in the northern Santa Ana Mountains before January 1, 1959. Elevations, depths, and locations are in feet, and the operator's names are those in use in 1958

\begin{tabular}{|c|c|c|c|c|c|c|c|c|}
\hline Operator & Well & Location & $\begin{array}{l}\text { Elev- } \\
\text { ation }\end{array}$ & $\begin{array}{l}\text { Total } \\
\text { depth }\end{array}$ & Spud & $\begin{array}{c}\text { Present } \\
\text { status }\end{array}$ & Geology & Remarks \\
\hline Aeco Corp. & Nohl-Bixby No. 1 & $\begin{array}{l}1,000 \mathrm{~S} . \text { and } 400 \mathrm{~W} . \text { of } \\
\text { N.E. cor. sec. } 12, \mathrm{~T} .4 \\
\text { S., R. } 9 \text { W. }\end{array}$ & 514 & 3,050 & $8 / 30 / 56$ & $\begin{array}{c}\text { Aban- } \\
\text { doned } \\
9 / 10 / 56\end{array}$ & 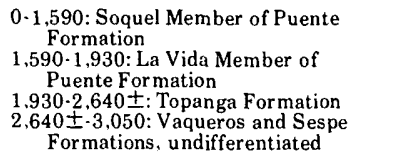 & \\
\hline $\begin{array}{l}\text { A merada Petrol. } \\
\text { eum Corp. }\end{array}$ & Irvine No. 63-1 & $\begin{array}{l}2.310 \mathrm{SW} \text { and } 330 \mathrm{SE} \\
\text { from the N. cor. of } \\
\text { Irvine Ranch Block } 63 .\end{array}$ & 71 & 3,920 & $5 / 29 / 49$ & $\begin{array}{c}\text { Aban- } \\
\text { doned } \\
6 / 18 / 49\end{array}$ & $\begin{array}{l}0-450 \pm: \text { Alluvium } \\
450 \pm \cdot 1,300 \pm \text { : La Habra (?) } \\
\text { Formation with interbedded marine } \\
\text { sedimentary rocks } \\
1,300 \pm \cdot 2,220: \text { Upper member of } \\
\text { Fernando Formation } \\
2,220 \cdot 3,540: \text { Puente Formation } \\
3,540 \cdot 3,920: \text { Williams Formation }\end{array}$ & $\begin{array}{l}\text { Ditch sample at } 480 \\
\text { reported to contain } \\
\text { foraminifers of } \\
\text { Pleistocene age. } \\
\text { Ditch sample from } \\
2.860 \text { to } 2.880 \text { reported } \\
\text { to contain } \\
\text { foraminifers of the } \\
\text { upper part of the } \\
\text { Mohnian stage. Core } \\
\text { from } 3.729 \text { to } 3.749 \\
\text { reported to contain } \\
\text { foraminifers of } \\
\text { Late Cretaceous age. }\end{array}$ \\
\hline $\begin{array}{l}\text { Bixby Hills Oil } \\
\text { Co. }\end{array}$ & Bixby No. 1 & $\begin{array}{l}300 \mathrm{~S} \text {. and } 1.975 \mathrm{~W} . \text { of } \\
\text { NE. cor. sec. } 11, \mathrm{~T} .4 \\
\text { S., R. } 9 \mathrm{~W} .\end{array}$ & $410 \pm$ & 4,673 & $?$ & $\begin{array}{c}\text { Aban- } \\
\text { doned } \\
1 / 21 / 22\end{array}$ & 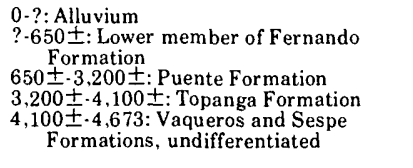 & $\begin{array}{l}\text { Driller's log } \\
\text { only data } \\
\text { available. }\end{array}$ \\
\hline $\begin{array}{l}\text { California Eastern } \\
\text { Oil Co. }\end{array}$ & Verde No. 1 & $\begin{array}{l}425 \mathrm{~S} \text {. and } 575 \text { E. of NW. } \\
\text { cor. proj. sec. } 31 \text {, T. } \\
3 \text { S., R. } 9 \text { W. }\end{array}$ & 255 & 4,897 & $7 / 23 / 33$ & $\begin{array}{c}\begin{array}{c}\text { Aban- } \\
\text { doned } \\
12 / 11 / 36\end{array} \\
\end{array}$ & 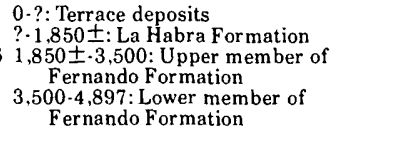 & $\begin{array}{l}\text { Formerly known as } \\
\text { Placentia Develop- } \\
\text { ment Co. Verde No. } 1 .\end{array}$ \\
\hline Carrey, A. A. & Bixby-Nohl No. 1 & $\begin{array}{l}2,300 \mathrm{~N} \text {. and } 2,150 \mathrm{E} \\
\text { of SW. cor. sec. } 9, \dot{\mathrm{T}} \text {. } \\
4 \mathrm{~S} ., \mathrm{R} .9 \mathrm{~W} .\end{array}$ & $480 \pm$ & 3,758 & $6 / 16 / 53$ & $\begin{array}{c}\text { Aban. } \\
\text { doned } \\
6 / 25 / 53\end{array}$ & 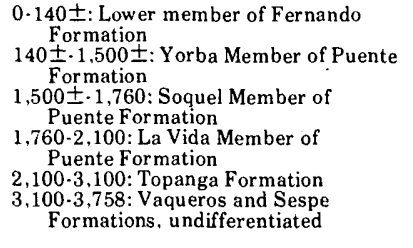 & \\
\hline $\begin{array}{l}\text { Christopher Oil } \\
\text { Co. }\end{array}$ & $\begin{array}{l}\text { Anaheim Union } \\
\text { Water No. } 1\end{array}$ & $\begin{array}{l}2,250 \mathrm{~N} . \text { and } 2,075 \mathrm{~W} \text {. } \\
\text { of SE. cor. sec. } 32, \mathrm{~T} \text {. } \\
3 \mathrm{~S} \text {. R. } 9 \text { W. }\end{array}$ & 235 & 5,660 & $7 / 24 / 54$ & $\begin{array}{c}\text { Aban. } \\
\text { doned } \\
8 / 17 / 54\end{array}$ & $\begin{array}{l}0 \cdot ?: \text { Alluvium } \\
? \cdot 1,010: \text { La Habra Formation } \\
\text { 1,010-2,190: Upper member of } \\
\text { Fernando Formation } \\
\text { 2,190-3,750: Lower member of } \\
\text { Fernando Formation } \\
\text { 3,750.3,978: Sycamore Canyon member } \\
\text { of Puente Formation } \\
\text { 3,978-5,038: Yorba Member of Puente } \\
\text { Formation } \\
\text { 5.038-5,660: Soquel Member of } \\
\text { Puente Formation }\end{array}$ & $\cdot$ \\
\hline Doheny, Patrick A. & Campbell No. 1 & $\begin{array}{l}2,450 \mathrm{~N} \text {. and } 2,200 \mathrm{E} \text {. } \\
\text { of } \mathrm{SW} \text {. cor. proj. sec. } \\
35 . \mathrm{T} .3 \mathrm{~S} \text {., R. } 9 \text { W. }\end{array}$ & 335 & 3,405 & $8 / 31 / 56$ & $\begin{array}{c}\text { Aban- } \\
\text { doned } \\
9 / 10 / 56\end{array}$ & $\begin{array}{l}\text { 0-?: Terrace deposits } \\
\text { ?-420: Upper Member of Fernando } \\
\text { Formation } \\
\text { 420-1,430: Lower member of F ernando } \\
\text { Formation } \\
\text { 1,430-2,250: Sycamore Canyon Member } \\
\text { of Puente Formation } \\
2,250-3,265: \text { Yorba Member of Puente } \\
\text { Formation } \\
\text { 2,320-2,637: Chapman sand in Yorba } \\
\text { Member of Puente Formation } \\
\text { 3,265-3,405: Soquel Member of } \\
\text { Puente Formation }\end{array}$ & $\begin{array}{l}\text { Bottom hole } \\
\text { coordinates: } 238 \\
\text { N. and } 197 \text { E. of } \\
\text { surface location. }\end{array}$ \\
\hline Do. & Stern No. 1 & $\begin{array}{l}2,900 \mathrm{~N} \text {. and } 1,875 \mathrm{~W} \text {. of } \\
\mathrm{SE} \text {. cor. proj. sec. } 35 \text {, } \\
\text { T. } 3 \mathrm{~S} \text {., R. } 9 \text { W. }\end{array}$ & 399 & 3,300 & $5 / 15 / 56$ & $\begin{array}{l}\text { Pro- } \\
\text { ducing }\end{array}$ & $\begin{array}{l}\text { 0-1,310: Lower member of Fernando } \\
\text { Formation } \\
\text { 1,310-2,240: Sycamore Canyon Member } \\
\text { of Puente Formation } \\
\text { 2,240-3,155:Yorba Member of } \\
\text { Puente Formation } \\
\text { 2,310-2,490: Chapman sand in Yorba } \\
\text { Member of Puente Formation } \\
\text { 3,155-3,300: Yorba Member of } \\
\text { Puente Formation }\end{array}$ & \\
\hline Do. & Stern No. 2 & $\begin{array}{l}2,850 \mathrm{~N} \text {. and } 1,750 \mathrm{~W} . \\
\text { of SE. cor. proj. sec. } \\
\text { 35, T. } 3 \mathrm{~S} ., \mathrm{R} .9 \mathrm{~W} .\end{array}$ & 399 & 3,202 & $8 / 8 / 56$ & $\begin{array}{l}\text { Pro- } \\
\text { ducing }\end{array}$ & $\begin{array}{l}0-1,285: \text { Lower member of } \\
\text { Fernando Formation } \\
\text { 1,285-2,215: Sycamore Canyon Member } \\
\text { of Puente Formation } \\
\text { 2,215-3,163: Yorba Member of } \\
\text { Puente Formation } \\
\text { 2,280-2,533: Chapman sand in Yorba } \\
\text { Member of Puente Formation } \\
\text { 3,163-3,202: Soquel Member of } \\
\text { Puente Formation }\end{array}$ & $\begin{array}{l}\text { Bottom hole } \\
\text { coordinates: } \\
240 \text { N. and } 199 \\
\text { E. of surface } \\
\text { location. }\end{array}$ \\
\hline
\end{tabular}


WELL LOCATIONS AND RELATED DATA-CONTINUED

[Wildcat wells, core holes, and selected producing wells drilled in the northern Santa Ana Mountains before January 1, 1959. Elevations, depths, and locations are in feet, and the operator's names are those in use in 1958 ]

\begin{tabular}{|c|c|c|c|c|c|c|c|c|}
\hline Operator & Well & Location & $\begin{array}{l}\text { Elev- } \\
\text { ation }\end{array}$ & $\begin{array}{l}\text { Total } \\
\text { depth }\end{array}$ & Spud & $\begin{array}{l}\text { Present } \\
\text { status }\end{array}$ & Geology & Remarks \\
\hline \multirow[t]{2}{*}{ Do. } & $\begin{array}{l}\text { Stern No. } 3 \\
\text { (original hole) }\end{array}$ & $\begin{array}{l}2.750 \mathrm{~N} \text {. and } 1.650 \mathrm{~W} \text {. of } \\
\mathrm{SE} . \text { cor. proj. sec. } 35 \text {, } \\
\text { T. } 3 \mathrm{~S} . \text { R. } 9 \mathrm{~W} .\end{array}$ & 398 & 3,418 & $10 / 23 / 56$ & & $\begin{array}{l}0 \cdot 1.258: \text { Lower member of } \\
\text { Fernando Formation } \\
1.258-2,190: \text { Sycamore Canyon Member } \\
\text { of Puente Formation } \\
2,190-3.205 \text { Yorba Member of } \\
\text { Puente Formation } \\
2.260 \cdot 2.505 \text { Chapman sand in Yorba } \\
\text { Member of Puente Formation } \\
3.205-3,418 \text { Soquel Member of } \\
\text { Puente Formation }\end{array}$ & $\begin{array}{l}\text { Bottom hole } \\
\text { coordinates: } 346 \\
\text { N. and } 444 \mathrm{E} . \\
\text { of surface loca. } \\
\text { tion. }\end{array}$ \\
\hline & $\begin{array}{c}\text { Stern No. } 3 \\
\text { (redrill) }\end{array}$ & & & 3,191 & & $\begin{array}{c}\text { Aban: } \\
\text { doned } \\
11 / 11 / 56\end{array}$ & $\begin{array}{l}0 \cdot 1.260 \pm: \text { Lower member of } \\
\text { Fernando Formation } \\
\text { 1.260 } \pm \cdot 2,180: \text { Sycamore Canyon Member } \\
\text { of Puente Formation } \\
2.180 \cdot 3.130: \text { Yorba Member of } \\
\text { Puente Formation } \\
2.240 \cdot 2.505: \text { Chapman sand in Yorba } \\
\text { Member of Puente Formation } \\
\text { 3.130.3.191: Soquel Member of } \\
\text { Puente Formation }\end{array}$ & $\begin{array}{l}\text { Bottom hole } \\
\text { coordinates: } 47 \\
\mathrm{~N} \text {. and 191 E. } \\
\text { of surface } \\
\text { location. }\end{array}$ \\
\hline $\begin{array}{l}\text { Drilling and } \\
\text { Exploration Co. }\end{array}$ & $\begin{array}{l}\text { Drilexco-State- } \\
\text { Bennett No. } 1\end{array}$ & $\begin{array}{l}2,075 \mathrm{~N} \text {. and } 3,300 \mathrm{~W} \text {. } \\
\text { of SE. cor. sec. } 32 \text {. T. } \\
3 \mathrm{~S} . . \mathrm{R} .9 \mathrm{~W} .\end{array}$ & 242 & 5.854 & $1 / 30 / 54$ & $\begin{array}{c}\text { Aban- } \\
\text { doned } \\
3 / 1 / 54\end{array}$ & $\begin{array}{l}0 \cdot ?: \text { Alluvium } \\
? \cdot 1,345: \text { La Habra Formation } \\
1,345-2,690: \text { Upper member of } \\
\text { Fernando Formation } \\
\text { 2,690-4,142: Lower member of } \\
\text { Fernando Formation } \\
4,142 \cdot 4,278: \text { Sycamore Canyon Member } \\
\text { of Puente Formation } \\
4.278 \cdot 5,350: \text { Yorba Member of } \\
\text { Puente Formation } \\
5.350-5.854 \text { : Soquel Member of } \\
\text { Puente Formation }\end{array}$ & \\
\hline Do. & $\begin{array}{l}\text { Drilexco } \cdot \text { State- } \\
\text { Stern No. } 1\end{array}$ & $\begin{array}{l}2.800 \text { N. and } 125 \text { W. of } \\
\text { SE. cor. sec. } 32, \text { T. } 3 \\
\text { S.. R. } 9 \text { W. }\end{array}$ & 248 & 4,985 & $4 / 12 / 53$ & $\begin{array}{l}\text { Pro- } \\
\text { ducing }\end{array}$ & 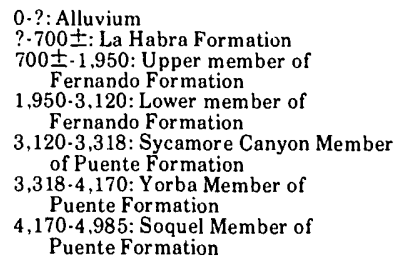 & $\begin{array}{l}\text { In Richfield oil } \\
\text { field. }\end{array}$ \\
\hline Equality Oil Co. & Irvine No. 1 & $\begin{array}{l}2.550 \mathrm{NE} \text {. and } 1,225 \\
\mathrm{NW} \text {. from the S. cor. } \\
\text { of Irvine Ranch Block } \\
115 .\end{array}$ & $1,080 \pm$ & 5,044 & $4 / 23 / 57$ & $\begin{array}{c}\text { Aban- } \\
\text { doned } \\
1958\end{array}$ & 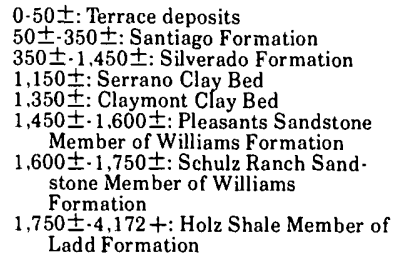 & $\begin{array}{l}\text { No data available } \\
\text { below } 4,172 \text {. Top } \\
\text { of Santiago Peak } \\
\text { Volcanics report- } \\
\text { ed at } 4.810 ; \text { and } \\
\text { top of Bedford } \\
\text { Canyon Formation } \\
\text { reported at } 4.997 \text {. }\end{array}$ \\
\hline Gale, Hoyt S. & Irvine No. 1 & $\begin{array}{l}350 \text { S. and } 3.050 \text { E. of } \\
\text { NW. cor. sec. } 31 \text {, T. } 5 \\
\text { S., R. } 9 \text { W. }\end{array}$ & 45 & 2,224 & $4 / 29 / 25$ & $\begin{array}{l}\text { Aban } \\
\text { doned } \\
6 / 25\end{array}$ & $\begin{array}{l}0 \cdot 300 \pm: \text { Alluvium } \\
300 \pm-1,475 \pm: \text { Marine and non } \cdot \text { marine } \\
\text { sand, gravel, and clay of } \\
\text { Pleistocene and possibly } \\
\text { Pliocene age } \\
\text { 1,475 } \pm-1,990 \pm \text { Puente } \\
\text { Formation or } \\
\text { Monterey Shale } \\
\text { 1,990 } \pm-2,224: \text { Topanga Formation } \\
\text { with interbedded volcanic } \\
\text { agglomerate or breccia }\end{array}$ & $\begin{array}{l}\text { Geology above } \\
1,990 \text { questionable, } \\
\text { very poor data. } \\
\text { "Sea Shells" } \\
\text { reported between } \\
410 \cdot 625 .\end{array}$ \\
\hline $\begin{array}{l}\text { General Petroleum } \\
\text { Corp. }\end{array}$ & Basin-Stern No. 1 & $\begin{array}{l}2,125 \mathrm{~N} \text {. and } 1.550 \mathrm{E} . \\
\text { of SW. cor. sec. } 33, \mathrm{~T} \text {. } \\
3 \mathrm{~S} ., \mathrm{R} .9 \mathrm{~W} .\end{array}$ & 254 & 4,840 & $5 / 29 / 46$ & $\begin{array}{l}\text { Pro- } \\
\text { ducing }\end{array}$ & 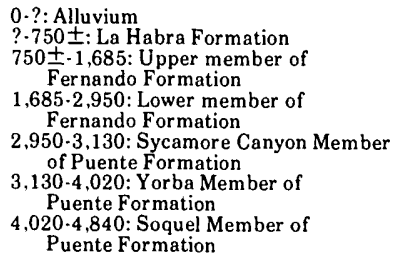 & $\begin{array}{l}\text { In Richfield oil } \\
\text { field. Formerly } \\
\text { known as Basin } \\
\text { Oil Co. Stern No. 1. }\end{array}$ \\
\hline $\begin{array}{l}\text { Godfrey Drilling } \\
\text { Co. }\end{array}$ & Botiller No. 1 & $\begin{array}{l}950 \mathrm{~N} . \text { and } 1.475 \mathrm{~W} \text {. of } \\
\text { SE. cor. prcj. sec. } 29 \text {, } \\
\text { T. } 3 \text { S., R. } 7 \text { W. }\end{array}$ & $600 \pm$ & 4,775 & $7 / 16 / 54$ & $\begin{array}{c}\text { Aban- } \\
\text { doned } \\
5 / 26 / 55\end{array}$ & $\begin{array}{l}0-1,840: \text { Vaqueros and Sespe } \\
\text { Formation, undifferentiated } \\
\text { 1,840-2,685: Santiago Formation } \\
2,685-4,500: \text { Silverado Formation } \\
4,500-4,775: \text { Ladd Formation }\end{array}$ & \\
\hline Heffern Oil Co. & Heffern No. 1 & $\begin{array}{l}1,750 \mathrm{~N} . \text { and } 725 \mathrm{~W} . \text { of } \\
\text { SE. cor. proj. sec. } 31 \text {, } \\
\text { T. } 3 \text { S., R. } 9 \text { W. }\end{array}$ & $225 \pm$ & 4,575 & $3 / 17 / 19$ & $\begin{array}{l}\text { Aban- } \\
\text { doned } \\
10 . / 23\end{array}$ & & No data available. \\
\hline $\begin{array}{l}\text { Independent } \\
\text { Exploration Co. }\end{array}$ & $\begin{array}{l}\text { South Placentia } \\
\text { Community } 30 \\
\text { No. } 1\end{array}$ & $\begin{array}{l}100 \mathrm{~N} . \text { and } 2,025 \mathrm{~W} . \text { of } \\
\text { SE. cor. proj. sec. } 6 \text {, } \\
\text { T. } 4 \text { S.. R. } 9 \text { W. }\end{array}$ & 229 & 4,804 & $7 / 6 / 49$ & $\begin{array}{c}\text { Aban: } \\
\text { doned } \\
8 / 4 / 49\end{array}$ & $\begin{array}{l}\text { 0·?: Alluvium } \\
\text { ?-1,035: La Habra Formation } \\
1,035 \cdot 2,285: \text { Upper member of } \\
\text { Fernando Formation } \\
\text { 2,285-3,980: Lower member of } \\
\text { Fernando Formation } \\
3,980 \cdot 4,804: \text { Puente Formation }\end{array}$ & \\
\hline
\end{tabular}




\section{WELL LOCATIONS AND RELATED DATA - CONTINUED}

[Wildcat wells, core holes, and selected producing wells drilled in the northern Santa Ana Mountains before January 1, 1959. Elevations, depths, and locations are in feet, and the operator's names are those in use in 1958 ]

\begin{tabular}{|c|c|c|c|c|c|c|c|c|}
\hline Operator & Well & Location & $\begin{array}{l}\text { Elev- } \\
\text { ation }\end{array}$ & $\begin{array}{l}\text { Total } \\
\text { depth }\end{array}$ & Spud & $\begin{array}{l}\text { Present } \\
\text { status }\end{array}$ & Geology & Remarks \\
\hline Kesselman, Lyle E. & $\begin{array}{l}\text { Kesselman- } \\
\text { Yorba No. } 1\end{array}$ & $\begin{array}{l}275 \mathrm{~S} \text {. and } 150 \mathrm{E} \text {. of } \\
\text { NW. cor. proj. sec. } 31 \text {, } \\
\text { T. } 3 \text { S., R. } 8 \text { W. }\end{array}$ & 328 & 3,217 & $9 / 22 / 57$ & $\begin{array}{c}\text { Aban- } \\
\text { doned } \\
10 / 3 / 57\end{array}$ & $\begin{array}{l}\text { 0-?: Alluvium } \\
\text { ?-1,300: Sycamore Canyon Member } \\
\text { of Puente Formation } \\
\text { 1,300-3,217: Yorba Member of } \\
\text { Puente Formation } \\
\text { 1,570-1,950: Chapman sand in Yorba } \\
\text { Member of Puente Formation }\end{array}$ & \\
\hline Landess Oil Co. & Well No. 1 & $\begin{array}{l}150 \mathrm{~N} . \text { and } 600 \mathrm{E} . \text { of } \\
\text { SW cor. sec. } 31, \mathrm{~T} . \\
3 \mathrm{~S} ., \mathrm{R} .8 \mathrm{~W} .\end{array}$ & 400 & 3,119 & $8 / 8 / 47$ & $\begin{array}{c}\text { Aban. } \\
\text { doned } \\
10 / 7 / 47\end{array}$ & $\begin{array}{l}0-1,130: \text { Sycamore Canyon Member } \\
\text { of Puente Formation } \\
\text { 1,130-2,275: Yorba Member of } \\
\text { Puente Formation } \\
\text { 1,730-2,100: Chapman sand in Yorba } \\
\text { Member of Puente Formation } \\
\text { 2,275-3,119: Soquel Member of } \\
\text { Puente Formation }\end{array}$ & \\
\hline Lockhart, L. M. & Budlong No. 1 & $\begin{array}{l}1,725 \mathrm{~S} . \text { and } 750 \mathrm{~W} . \text { of } \\
\text { NE cor. proj. sec. } 34, \\
\text { T. } 3 \text { S., R. } 9 \text { W. }\end{array}$ & 278 & 6,016 & $5 / 28 / 47$ & $\begin{array}{c}\text { Aban- } \\
\text { doned } \\
7 / 22 / 47\end{array}$ & 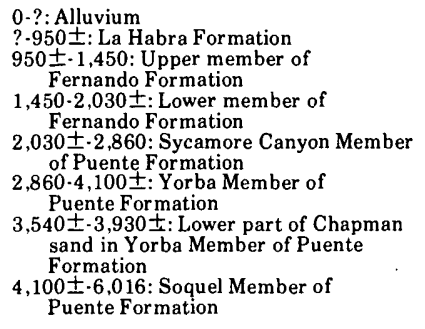 & \\
\hline $\begin{array}{l}\text { Long Beach } \\
\text { Consolidated } \\
\text { Oil Co. }\end{array}$ & Well No. 2 & $\begin{array}{l}2,025 \text { S. and } 2,350 \\
\text { W. of NE. cor. sec. } 9 \text {, } \\
\text { T. } 4 \text { S., R. } 9 \text { W. }\end{array}$ & $440 \pm$ & 2,678 & $6 / 10 / 20$ & $\begin{array}{c}\text { Aban- } \\
\text { doned } \\
5 / 21 / 21\end{array}$ & $\begin{array}{l}\text { 0.950 } \pm: \text { Lower member of } \\
\text { Fernando Formation } \\
950 \pm-2,678: \text { Puente Formation }\end{array}$ & $\begin{array}{l}\text { Driller's log } \\
\text { only data } \\
\text { available. }\end{array}$ \\
\hline McKee Oil Co. & $\begin{array}{l}\text { Kokx Community } \\
\text { No. } 8 \cdot 1\end{array}$ & $\begin{array}{l}2,800 \mathrm{~S} \text {. and } 1,600 \mathrm{E} . \\
\text { of NW. cor. sec. } 16, \mathrm{~T} \text {. } \\
4 \mathrm{~S} . \mathrm{R} .9 \mathrm{~W} .\end{array}$ & 274 & 4,005 & $1 / 1 / 46$ & $\begin{array}{l}\text { Aban- } \\
\text { doned } \\
2 / 8 / 46\end{array}$ & 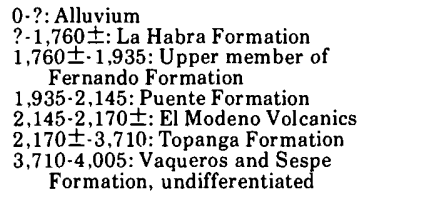 & $\begin{array}{l}\text { Foraminifers and } \\
\text { mollusks found } \\
\text { in Topanga } \\
\text { Formation. } \\
\text { See locality } \\
\text { m } 182 \text { and } \\
\text { locality F } 160 .\end{array}$ \\
\hline Murdock, G. D. & Howell No. 1 & $\begin{array}{l}2,100 \mathrm{~S} \text {. and } 2,750 \mathrm{~W} \text {. of } \\
\text { NE. cor. sec. } 1, \text { T. } 4 \\
\text { S., R. } 9 \text { W. }\end{array}$ & 308 & 4,370 & $7 / 3 / 46$ & $\begin{array}{l}\text { Aban- } \\
\text { doned } \\
3 / 9 / 48\end{array}$ & $\begin{array}{l}\text { 0-100 } \pm: \text { Alluvium } \\
\text { 100 } \pm \cdot 815: \text { Sycamore Canyon Member } \\
\text { of Puente Formation } \\
\text { 815-2,200: Yorba Member of } \\
\text { Puente Formation } \\
\text { 935-2,130: Chapman sand in Yorba } \\
\text { Member of Puente Formation } \\
\text { 2,200-3,505: Soquel Member of } \\
\text { Puente Formation } \\
\text { 3,505-3,895: La Vida Member of } \\
\text { Puente Formation } \\
\text { 3,895-4,370: Topanga Formation }\end{array}$ & \\
\hline $\begin{array}{l}\text { National Securities } \\
\text { Oil Co. }\end{array}$ & Irvine No. 1 & $\begin{array}{l}2,425 \mathrm{SW} \text {. and } 600 \\
\text { NW. from the E. cor. } \\
\text { of Irvine Ranch Block } \\
17 \text {. }\end{array}$ & $550 \pm$ & 5,147 & $10 / 4 / 20$ & $\begin{array}{c}\text { Aban- } \\
\text { doned } \\
11 / 6 / 25\end{array}$ & 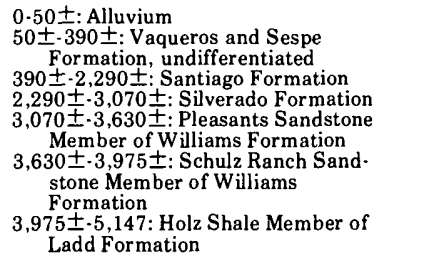 & $\begin{array}{l}\text { Driller's log only } \\
\text { data available, } \\
\text { interpretation } \\
\text { very questionable. }\end{array}$ \\
\hline $\begin{array}{l}\text { North Star } \\
\text { Mining and } \\
\text { Development Co. }\end{array}$ & Johnson No. 1 & $\begin{array}{l}2,075 \mathrm{~N} . \text { and } 1,750 \mathrm{E} . \\
\text { of SW. cor. sec. } 8, \mathrm{~T} \text {. } \\
5 \text { S., R. } 7 \text { W. }\end{array}$ & $1,440 \pm$ & 490 & $8 / 4 / 48$ & $\begin{array}{c}\text { Aban- } \\
\text { doned } \\
5 / 31 / 49\end{array}$ & $\begin{array}{l}0-50 \pm: \text { Terrace deposits } \\
50 \pm-490: \text { Santiago Peak Volcanics }\end{array}$ & $\begin{array}{l}\text { No data available, } \\
\text { geology based on } \\
\text { surface location. }\end{array}$ \\
\hline $\begin{array}{l}\text { Olive Petroleum } \\
\text { Co. }\end{array}$ & Well No. 1 & $\begin{array}{l}2,600 \mathrm{~N} . \text { and } 2,400 \mathrm{E} \text {. } \\
\text { of SW. cor. sec. } 8, \mathrm{~T} \text {. } \\
4 \mathrm{~S} ., \mathrm{R} .9 \mathrm{~W} .\end{array}$ & $240 \pm$ & 3,640 & $2 / 19 / 20$ & $\begin{array}{l}\text { Aban- } \\
\text { doned } \\
1922\end{array}$ & 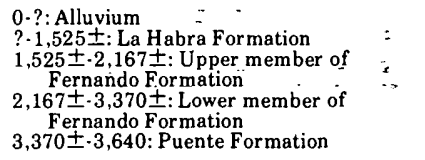 & $\begin{array}{l}\text { Driller's log only } \\
\text { data available. }\end{array}$ \\
\hline $\begin{array}{l}\text { Olive-Ventura } \\
\text { Oil Corp. }\end{array}$ & Bixby No. 1 & $\begin{array}{l}1,350 \text { N. and } 25 \text { W. of } \\
\text { SE. cor. sec. } 9, \text { T. } 4 \\
\text { S., R. } 9 \text { W. }\end{array}$ & 592 & 4,710 & $1 / 24 / 24$ & $\begin{array}{c}\text { Aban- } \\
\text { doned } \\
1925\end{array}$ & 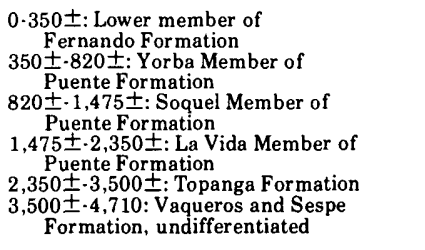 & $\begin{array}{l}\text { Good driller's log } \\
\text { only data avail- } \\
\text { able. Also known } \\
\text { as Eskridge and } \\
\text { Craise Oil Co. } \\
\text { Bixby No. } 1 .\end{array}$ \\
\hline
\end{tabular}




\section{WELL LOCATIONS AND RELATED DATA-CONTINUED}

[Wildcat weils, core holes, and selected producing wells drilled in the northern Santa Ana Mountains before January 1, 1959. Elevations, depths, and locations are in feet, and the operator's names are those in use in 1958 ]

\begin{tabular}{|c|c|c|c|c|c|c|c|c|}
\hline Operator & Well & Location & $\begin{array}{l}\text { Elev- } \\
\text { ation }\end{array}$ & $\begin{array}{l}\text { Total } \\
\text { depth }\end{array}$ & Spud & $\begin{array}{l}\text { Present } \\
\text { status }\end{array}$ & Geology & Remarks \\
\hline $\begin{array}{l}\text { Orange Comnunity } \\
\text { Oil Association }\end{array}$ & Forker No. 1 & $\begin{array}{l}775 \mathrm{~S} \text {. and } 2.600 \mathrm{~W} . \text { of } \\
\text { NE. cor. sec. } 29, \text { T. } 4 \\
\text { S.. R. } 9 \text { W. }\end{array}$ & $225 \pm$ & $5.000 \pm$ & $9 / 27 / 23$ & $\begin{array}{l}\text { Aban: } \\
\text { doned } \\
5 / 8 / 24\end{array}$ & 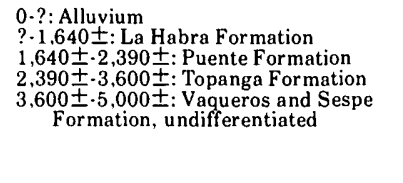 & 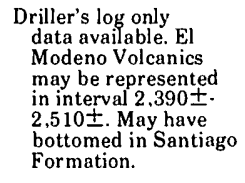 \\
\hline $\begin{array}{l}\text { Owners Oil } \\
\text { Producers Co. }\end{array}$ & Monette No. 1 & $\begin{array}{l}2,200 \mathrm{~S} . \text { and } 1,325 \mathrm{~W} . \\
\text { of NE. cor. sec. } 24 . \\
\text { T. } 4 \text { S..R. } 9 \text { W. }\end{array}$ & $580 \pm$ & 2,880 & $9 / 20$ & $\begin{array}{l}\text { Aban: } \\
\text { doned } \\
1 / 28 / 25\end{array}$ & & $\begin{array}{l}\text { Driller's log only } \\
\text { data available, } \\
\text { no interpretation } \\
\text { possible. }\end{array}$ \\
\hline $\begin{array}{l}\text { Pacific Central } \\
\text { Oil Co. }\end{array}$ & Boisseranc No. 1 & $\begin{array}{l}2.375 \mathrm{~S} . \text { and } 2.225 \mathrm{~W} . \\
\text { of NE. cor. proj. sec. } \\
34 \text {.T. } 3 \text { S.. R. } 9 \mathrm{~W} .\end{array}$ & 268 & 4.366 & $6 / 30 / 45$ & $\begin{array}{c}\text { Aban- } \\
\text { doned } \\
9 / 26 / 45\end{array}$ & $\begin{array}{l}0 \cdot ?: \text { Alluvium } \\
? \cdot 945 \pm: \text { La Habra Formation } \\
945 \pm-1,600: \text { Upper member of } \\
\text { Fernando Formation } \\
\text { 1,600-2,410: Lower member of } \\
\text { Fernando Formation } \\
2,410-2,900: \text { Sycamore Canyon Member } \\
\text { of Puente Formation } \\
\text { 2,900-4,240: Yorba Member of } \\
\text { Puente Formation } \\
\text { 2,980-4,050 } 1 \text { : Chapman sand in Yorba } \\
\text { Member of Puente Formation } \\
\text { 4,240-4,366: Soquel Member of } \\
\text { Puente Formation }\end{array}$ & \\
\hline Red Star Oil Co. & $\begin{array}{l}\text { Ward Associates } \\
\text { No. } 1\end{array}$ & $\begin{array}{l}275 \mathrm{SE} \text {. and } 200 \mathrm{SW} \text {. } \\
\text { from the N. cor. of } \\
\text { Irvine Ranch Block } 9 \text {. }\end{array}$ & $66 \pm$ & 5,247 & $7 / 16 / 56$ & $\begin{array}{c}\text { Aban- } \\
\text { doned } \\
8 / 13 / 56\end{array}$ & $\begin{array}{l}0-?: \text { Alluvium } \\
? \cdot 2.510: \text { Marine and nonmarine sand, } \\
\text { gravel, and silt of Pleistocene } \\
\text { and possibly Pliocene age } \\
\text { 2,5 10-3,140: Puente Formation } \\
\text { or Monterey Shale } \\
\text { 3,140-4,465: Topanga Formation } \\
\text { 4,465-5,247: Vaqueros and Sespe } \\
\text { Formation, undifferentiated }\end{array}$ & . \\
\hline $\begin{array}{l}\text { Richfield Oil } \\
\text { Corp. }\end{array}$ & $\begin{array}{l}\text { Hamrick-Olive } \\
\text { No. } 1\end{array}$ & $\begin{array}{l}300 \mathrm{~S} \text {. and } 2.000 \mathrm{~W} . \text { of } \\
\text { NE. cor. sec. } 8 . \mathrm{T} .4 \\
\text { S.. R. } 9 \text { W. }\end{array}$ & $230 \pm$ & 2.679 & $8 / 26 / 44$ & $\begin{array}{c}\text { Aban } \\
\text { doned } \\
10 / 7 / 44\end{array}$ & 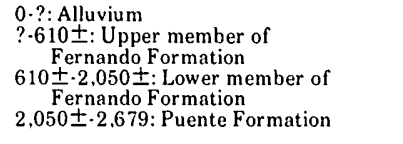 & \\
\hline Do. & $\begin{array}{l}\text { Mohawk·Krnemer } \\
\text { No. } 1\end{array}$ & $\begin{array}{l}75 \mathrm{~N} \text {. and } 1.825 \mathrm{E} \text {. of } \\
\text { SW. cor. proj. sec. } 25 \\
\text { T. } 3 \text { S.. R. } 9 \mathrm{~W} \text {. }\end{array}$ & $660 \pm$ & 4.208 & $5 / 21 / 45$ & $\begin{array}{c}\text { Aban: } \\
\text { doned } \\
6 / 28 / 45\end{array}$ & $\begin{array}{l}0 \cdot 2,600: \text { Sycamore Canyon Member } \\
\text { of Puente Formation } \\
2,600-3.580 \text { : Yorba Member of } \\
\text { Puente Formation } \\
\text { 2,675-2,720: Chapman sand in Yorba } \\
\text { Member of Puente Formation } \\
\text { 3.580-4.208: Soquel Member of } \\
\text { Puente Formation }\end{array}$ & \\
\hline Do. & $\begin{array}{l}\text { Peralta Hills } \\
\text { No. } 1\end{array}$ & $\begin{array}{l}1.400 \mathrm{~N} . \text { and } 2.675 \mathrm{E} . \\
\text { of SW. cor. sec. } 3 \text {, } \\
\text { T. } 4 \text { S., R. } 9 \text { W. }\end{array}$ & 392 & 4.605 & $1 / 23 / 50$ & $\begin{array}{c}\text { Aban- } \\
\text { doned } \\
2 / 21 / 50\end{array}$ & $\begin{array}{l}\text { 0.880: Lower member of } \\
\text { Fernando Formation } \\
880 \cdot 1,320: \text { Sycamore Canyon Member } \\
\text { of Puente Formation } \\
\text { 1,320-1,980: Yorba Member of } \\
\text { Puente Formation } \\
\text { 1,980-4,320: Soquel Member of } \\
\text { Puente Formation } \\
\text { 4,320-4,605: La Vida Member of } \\
\text { Puente Formation }\end{array}$ & \\
\hline Rubicon Oil Co. & Wilcox No. 1 & $\begin{array}{l}1.200 \text { S. and } 925 \text { E. of } \\
\text { NW. cor. sec. } 6, \text { T. } 4 \\
\text { S.. R. } 8 \text { W. }\end{array}$ & 450 & 6.325 & $5 / 8 / 47$ & $\begin{array}{c}\text { Aban- } \\
\text { doned } \\
6 / 22 / 47\end{array}$ & $\begin{array}{l}\text { 0-75 } \pm \text { : Terrace deposits } \\
75 \pm \cdot 515: \text { Sycamore Canyon Member } \\
\text { of Puente Formation } \\
515 \cdot 1,600: \text { Yorba Member of } \\
\text { Puente Formation } \\
900 \cdot 1,305: \text { Chapman sand in Yorba } \\
\text { Member of Puente Formation } \\
\text { 1,600.3,205: Soquel Member of } \\
\text { Puente Formation } \\
\text { 3,205-3.700: La Vida Member of } \\
\text { Puente Formation } \\
\text { 3,700.4,330: Topanga Formation } \\
\text { 4,330.5.780: Vaqueros and Sespe } \\
\text { Formation. undifferentiated } \\
\text { 5,780-6,325: Santiago Formation }\end{array}$ & \\
\hline $\begin{array}{l}\text { Suntu Ana Canyon } \\
\text { Oil Co. }\end{array}$ & Crowthers No. 1 & $\begin{array}{l}1.875 \mathrm{~N} . \text { and } 800 \text { E. of } \\
\text { SW. cor. proj. sec. } 32 \text {, } \\
\text { T. } 3 \text { S.. R. } 8 \text { W. }\end{array}$ & $440 \pm$ & 4,165 & $7 / 14 / 19$ & $\begin{array}{c}\text { Aban- } \\
\text { doned } \\
12 / 17 / 20\end{array}$ & 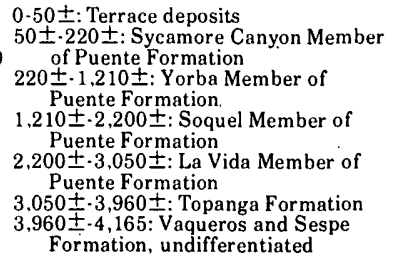 & $\begin{array}{l}\text { Driller's log } \\
\text { only data } \\
\text { available. }\end{array}$ \\
\hline
\end{tabular}




\section{WELL LOCATIONS AND RELATED DATA-CONTINUED}

[Wildcat wells, core holes, and selected producing wells drilled in the northern Santa Ana Mountains before January 1, 1959. Elevations, depths, and locations are in feet, and the operator's mes are those in use in 1958 ]

\begin{tabular}{|c|c|c|c|c|c|c|c|c|}
\hline Operator & Well & Location & $\begin{array}{l}\text { Elev- } \\
\text { ation }\end{array}$ & $\begin{array}{l}\text { Total } \\
\text { depth }\end{array}$ & Spud & $\begin{array}{c}\text { Present } \\
\text { status }\end{array}$ & Geology & Remarks \\
\hline Seaboard Oil Co. & Christensen No. 1 & $\begin{array}{l}800 \mathrm{~S} . \text { and } 1.550 \mathrm{~W} . \text { of } \\
\text { NE. cor. sec. } 5, \mathrm{~T} .4 \\
\text { S., R. } 9 \text { W. }\end{array}$ & 245 & 5,110 & $10 / 6 / 48$ & $\begin{array}{c}\text { Aban- } \\
\text { doned } \\
11 / 7 / 48\end{array}$ & $\begin{array}{l}0 \cdot ?: \text { Alluvium } \\
? \cdot 1,410: \text { La Habra Formation } \\
1,410 \cdot 3,210: \text { Upper member of } \\
\text { Fernando Formation } \\
\text { 3,2 10-4,280: Lower member of } \\
\text { Fernando Formation } \\
4,280 \cdot 4,370: \text { Sycamore Canyon Member } \\
\text { of Puente Formation } \\
4,370 \cdot 5,110: \text { Yorba Member of } \\
\text { Puente Formation }\end{array}$ & \\
\hline Shell Oil Co. & Allec No. 1 & $\begin{array}{l}2,800 \mathrm{~S} \text {. and } 975 \mathrm{E} \text {. of } \\
\text { NW. cor. proj. sec. } 31 \text {, } \\
\text { T. } 3 \text { S.. R. } 9 \text { W. }\end{array}$ & 236 & 5.656 & $5 / 23 / 27$ & $\begin{array}{c}\text { Aban- } \\
\text { doned } \\
1 / 12 / 28\end{array}$ & 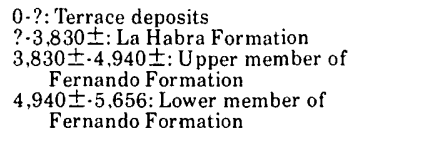 & \\
\hline Do. & $\begin{array}{l}\text { Irvine Core } \\
\text { Hole No. } 1\end{array}$ & $\begin{array}{l}1,300 \mathrm{SW} \text {. and } 575 \mathrm{SE} . \\
\text { from the N. cor. of } \\
\text { Irvine Ranch Block } 142 .\end{array}$ & 440 & 893 & $12 / 6 / 49$ & $\begin{array}{c}\text { Aban- } \\
\text { doned } \\
12 / 29 / 49\end{array}$ & $\begin{array}{l}\text { 0-460: Williams Formation } \\
\text { 460.893: Holz Shale Member of Ladd } \\
\text { Formation }\end{array}$ & \\
\hline Do. & $\begin{array}{l}\text { Irvine Core } \\
\text { Hole No. } 2\end{array}$ & $\begin{array}{l}575 \mathrm{SW} \text {. and } 2,650 \mathrm{SE} . \\
\text { from the } \mathrm{N} \text {. cor. of } \\
\text { Irvine Ranch Block } 121 .\end{array}$ & 301 & 1.008 & $12 / 30 / 49$ & $\begin{array}{l}\text { Aban- } \\
\text { doned } \\
1 / 19 / 50\end{array}$ & $\begin{array}{l}0 \cdot ?: \text { Alluvium } \\
\text { ?-710: La Habra Formation(?) } \\
710 \cdot 1.008: \text { Williams Formation }\end{array}$ & \\
\hline Do. & $\begin{array}{l}\text { Irvine Core } \\
\quad \text { Hole No. } 3\end{array}$ & $\begin{array}{l}2.575 \mathrm{SW} \text {. and } 2,575 \\
\text { SE. from the N. cor. of } \\
\text { Irvine Ranch Block } 86 .\end{array}$ & 82 & 2.006 & $1 / 20 / 50$ & $\begin{array}{l}\text { Aban: } \\
\text { doned } \\
2 / 20 / 50\end{array}$ & $\begin{array}{l}0 \cdot 305 \pm: \text { Alluvium } \\
305 \pm \cdot 905: \text { La Habra Formation(?) } \\
905-2,006 \text { : Vaqueros and Sespe } \\
\text { Formation, undifferentiated }\end{array}$ & \\
\hline Do. & $\begin{array}{c}\text { Irvine Core } \\
\text { Hole No. } 4\end{array}$ & $\begin{array}{l}1,250 \mathrm{NE} \text {. and } 1,450 \\
\mathrm{SE} \text {. from the W. cor of } \\
\text { lrvine Ranch Block } 105 .\end{array}$ & 184 & 2.615 & $6 / 15 / 50$ & $\begin{array}{c}\text { Aban: } \\
\text { doned } \\
7 / 15 / 50\end{array}$ & 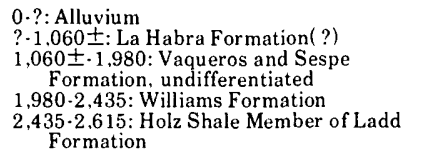 & \\
\hline Do. & $\begin{array}{l}\text { Irvine Core } \\
\text { Hole No. } 5\end{array}$ & $\begin{array}{l}2,250 \mathrm{SE} \text {. and } 3,200 \\
\text { SW. from the N. cor. of } \\
\text { Irvine Ranch Block } 121 .\end{array}$ & 284 & 3.263 & $2 / 25 / 50$ & $\begin{array}{c}\text { Aban- } \\
\text { doned } \\
4 / 1 / 50\end{array}$ & $\begin{array}{l}0-?: \text { Alluvium } \\
\text { ?-790: La Habra Formation(?) } \\
790 \cdot 1,185: \text { Williams Formation } \\
\text { 1.185.3.048: Holz Shale Member of Ladd } \\
\text { Formation } \\
\text { 3,048-3.263: Baker Canyon Conglomerate } \\
\text { Member of Ladd Formation }\end{array}$ & \\
\hline Do. & $\begin{array}{l}\text { Irvine Core } \\
\text { Hole No.12 }\end{array}$ & $\begin{array}{l}1,800 \mathrm{NW} \text {. and } 2,400 \\
\text { NE. from the } \mathrm{S} \text { cor. } \\
\text { of Irvine Ranch Block } \\
120 .\end{array}$ & 330 & 1,546 & $5 / 30 / 50$ & $\begin{array}{c}\text { Aban- } \\
\text { doned } \\
6 / 14 / 50\end{array}$ & $\begin{array}{l}0 \cdot ?: \text { Alluvium } \\
\text { ?-748: La Habra Formation (?) } \\
\text { 748.1,546: Holz Shale Member of Ladd } \\
\quad \text { Formation }\end{array}$ & \\
\hline Do. & Travis No. 1 & $\begin{array}{l}325 \mathrm{~S} . \text { and } 1,550 \mathrm{~W} . \text { of } \\
\text { NE. cor. proj. sec. } 36 \\
\text { T. } 3 \text { S., R. } 9 \text { W. }\end{array}$ & 357 & 6,158 & $7 / 11 / 54$ & $\begin{array}{c}\text { Aban- } \\
\text { doned } \\
9 / 14 / 54\end{array}$ & $\begin{array}{l}0 \cdot ?: \text { Alluvium } \\
? \cdot 1,190: \text { Sycamore Canyon Member } \\
\text { of Puente Formation } \\
\text { 1,190-3,480: Yorba Member of } \\
\text { Puente Formation } \\
\text { 1,355-1,503: Chapman sand in Yorba } \\
\text { Member of Puente Formation } \\
\text { 3,480-4,618: Soquel Member of } \\
\text { Puente Formation } \\
\text { 4,6 18-5,765: La Vida Member of } \\
\text { Puente Formation } \\
\text { 5,765-6,158: Topanga Formation }\end{array}$ & \\
\hline Shoreline Oil Co. & Pinkerton No. 1 & $\begin{array}{l}2,325 \mathrm{~S} . \text { and } 2,150 \mathrm{~W} . \\
\text { of NE. cor. sec. } 5, \mathrm{~T} \text {. } \\
5 \mathrm{~S} \text {., R. } 9 \text { W. }\end{array}$ & $187 \pm$ & 3,625 & $8 / 23 / 27$ & $\begin{array}{c}\text { Aban: } \\
\text { doned } \\
1 / 31 / 29\end{array}$ & 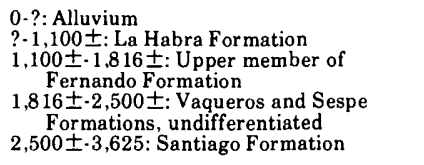 & $\begin{array}{l}\text { Also known as } \\
\text { C.A. Son Orangeana } \\
\text { No. } 1 \text {. }\end{array}$ \\
\hline Spook Oil Co. & $\begin{array}{l}\text { Stockwell Pool } \\
\text { No. } 1\end{array}$ & $\begin{array}{l}1,200 \mathrm{~N} . \text { and } 5,050 \mathrm{E} . \\
\text { of SW. cor. sec. } 33, \mathrm{~T} \text {. } \\
3 \mathrm{~S} . \text { R. } 9 \text { W. }\end{array}$ & 258 & 6,285 & $7 / 30 / 53$ & $\begin{array}{l}\text { Aban: } \\
\text { doned } \\
7 / 8 / 54\end{array}$ & $\begin{array}{l}0-?: \text { Alluvium } \\
? \cdot 1,460 \pm: \text { La Habra Formation } \\
1,460 \pm \cdot 2,550: \text { Upper member of } \\
\text { Fernando Formation } \\
2,550-3,580 \pm \text { : Lower member of } \\
\text { Fernando Formation } \\
\text { 3,580 } \pm-3,935: \text { Sycamore Canyon Member } \\
\text { of Puente Formation } \\
\text { 3,935-4,950: Yorba Member of } \\
\text { Puente Formation } \\
\text { 4,950-6,285: Soquel Member of } \\
\text { Puente Formation }\end{array}$ & $\begin{array}{l}\text { Formerly known as } \\
\text { Burhess Oil Co. } \\
\text { Stockwell Pool } \\
\text { No. 1. }\end{array}$ \\
\hline Standard Oil Co. & $\begin{array}{l}\text { Anaheim Union } \\
\text { Water No. } 1\end{array}$ & $\begin{array}{l}2,250 \text { N. and } 500 \text { W. of } \\
\text { SE. cor. proj. sec. } 35 \text {, } \\
\text { T. } 3 \text { S., R. } 9 \text { W. }\end{array}$ & 362 & 4,718 & $10 / 18 / 18$ & $\begin{array}{l}\text { Aban: } \\
\text { doned } \\
12 / 28 / 19\end{array}$ & . & $\begin{array}{l}\text { Driller's log only } \\
\text { data avalable, } \\
\text { no interpr etation } \\
\text { possible. }\end{array}$ \\
\hline Do. & Bixby No. 1 & $\begin{array}{l}525 \mathrm{~N} . \text { and } 1,050 \text { E. of } \\
\text { SW. cor. sec. } 9, \text { T. } 4 \\
\text { S., R. } 9 \text { W. }\end{array}$ & $345 \pm$ & 3,300 & $2 / 20 / 13$ & $\begin{array}{c}\text { Aban- } \\
\text { doned } \\
2 / 14 / 14\end{array}$ & $\begin{array}{l}\text { 0.200 } \text { : Upper member of } \\
\text { Fernando Formation } \\
200 \pm \cdot 400 \pm \text { : Lower member of } \\
\text { Fernando Formation } \\
400 \pm .1,860 \pm: \text { Puente Formation } \\
1,860 \pm \cdot 3,300 \pm \text { : Topanga Formation }\end{array}$ & $\begin{array}{l}\text { Driller's log only } \\
\text { data available, } \\
\text { interpretation } \\
\text { questionable. }\end{array}$ \\
\hline
\end{tabular}




\section{WELL LOCATIONS AND RELATED DATA-CONTINUED}

[Wildcat wells, core holes, and selected producing wells drilled in the northern Santa Ana Mountains before January 1, 1959. Elevations, depths, and locations are in feet, and the operator's names are those in use in 1958 ]

\begin{tabular}{|c|c|c|c|c|c|c|c|c|}
\hline Operator & Well & Location & $\begin{array}{l}\text { Elev- } \\
\text { ation }\end{array}$ & $\begin{array}{l}\text { Total } \\
\text { depth }\end{array}$ & Spud & $\begin{array}{c}\text { Present } \\
\text { status }\end{array}$ & Geology & Remarks \\
\hline Do. & $\begin{array}{l}\text { Edwards } \\
\text { Community No. }\end{array}$ & $\begin{array}{l}1,350 \mathrm{~S} \text {. and } 725 \text { E. of } \\
\text { NW. cor. proj. sec. } 34, \\
\text { T. } 3 \text { S., R. } 9 \text { W. }\end{array}$ & 330 & 4,350 & $10 / 28 / 34$ & $\begin{array}{c}\text { Pro- } \\
\text { ducing }\end{array}$ & 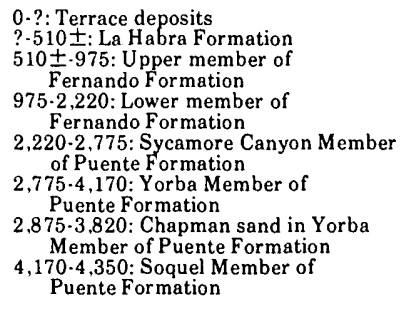 & $\begin{array}{l}\text { In Richfield oil } \\
\text { field. }\end{array}$ \\
\hline Do. & Kraemer No. $2 \cdot 25$ & $\begin{array}{l}300 \mathrm{~N} . \text { and } 2,275 \mathrm{~W} . \text { of } \\
\text { SE. cor. sec. } 29, \mathrm{~T} \text {. } \\
3 \mathrm{~S} ., \mathrm{R} .9 \mathrm{~W} .\end{array}$ & 270 & 4,500 & $5 / 27 / 37$ & $\begin{array}{l}\text { Pro- } \\
\text { ducing }\end{array}$ & $\begin{array}{l}\text { 0-?: Terrace deposits } \\
\text { ?-1,100: La Habra Formation } \\
\text { 1,100-1,920: Upper member of } \\
\text { Fernando Formation } \\
\text { 1,920-2,815: Lower member of } \\
\text { Fernando Formation } \\
\text { 2,815-2,990: Sycamore Canyon Member } \\
\text { of Puente Formation } \\
\text { 2,990-3,800: Yorba Member of } \\
\text { Puente Formation } \\
\text { 3,085-3,315: Chapman sand in Yorba } \\
\text { Member of Puente Formation } \\
\text { 3,800-4,500: Soquel Member of } \\
\text { Puente Formation }\end{array}$ & Do. \\
\hline Do. & Locke No. 1 & $\begin{array}{l}2.500 \mathrm{~N} . \text { and } 1,550 \mathrm{~W} . \\
\text { of SE. cor. proj. sec. } \\
35 . \mathrm{T} .3 \mathrm{~S} ., \mathrm{R} .9 \mathrm{~W} .\end{array}$ & 368 & 3.795 & $11 / 3 / 18$ & $\begin{array}{l}\text { Aban: } \\
\text { doned } \\
4 / 1 / 20\end{array}$ & & $\begin{array}{l}\text { Driller's log only } \\
\text { data available. } \\
\text { no interpretation } \\
\text { possible. }\end{array}$ \\
\hline Do. & Locke No. 2 & $\begin{array}{l}1,500 \text { S. and } 750 \mathrm{~W} . \text { of } \\
\text { NE. cor. proj. sec. } 35 \\
\text { T. } 3 \text { S.. R. } 9 \text { W. }\end{array}$ & 530 & 4,006 & $7 / 3 / 19$ & $\begin{array}{l}\text { Aban: } \\
\text { doned } \\
7 / 24 / 20\end{array}$ & & Do. \\
\hline Do. & $\begin{array}{l}\text { Southeast } \\
\text { Richfield Unit } \\
\text { No. } 1\end{array}$ & $\begin{array}{l}2,050 \mathrm{~N} . \text { and } 450 \mathrm{~W} . \text { of } \\
\text { SE. cor. proj. sec. } 34, \\
\text { T. } 3 \text { S., R. } 9 \text { W. }\end{array}$ & 281 & 4.400 & $1 / 8 / 45$ & $\begin{array}{c}\text { Aban- } \\
\text { doned } \\
2 / 8 / 45\end{array}$ & $\begin{array}{l}\text { 0-?: Alluvium } \\
\text { ?-695 } \pm: \text { La Habra Formation } \\
\text { 695 } \pm \cdot 1,10: \text { Upper member of } \\
\text { Fernando Formation } \\
\text { 1,1 10-2,088: Lower member of } \\
\text { Fernando Formation } \\
\text { 2,088-2,750: Sycamore Canyon Member } \\
\text { of Puente Formation } \\
\text { 2,750-3,735: Yorba Member of } \\
\text { Puente Formation } \\
\text { 2,800-3,650: Chapman sand in Yorba } \\
\text { Member of Puente Formation } \\
\text { 3,735-4,400: Soquel Member of } \\
\text { Puente Formation }\end{array}$ & \\
\hline Do. & $\begin{array}{l}\text { Taft Community } \\
\text { No. } 1\end{array}$ & $\begin{array}{l}250 \text { S. and } 1,275 \mathrm{~W} . \\
\text { of NE. cor. sec. } 20 \\
\text { T. } 4 \text { S., R. } 9 \text { W. }\end{array}$ & 242 & 3,095 & $7 / 8 / 48$ & $\begin{array}{l}\text { Aban: } \\
\text { doned } \\
8 / 6 / 48\end{array}$ & $\begin{array}{l}\text { 0.?: Alluvium } \\
\text { ?-2,315: La Habra Formation } \\
\text { 2,315-2,445: Upper member of } \\
\text { Fernando Frrmation } \\
2,445 \cdot 3.006: \text { Puente Formation } \\
3,006 \cdot 3,095: \text { El Modeno Volcanics }\end{array}$ & \\
\hline Do. & $\begin{array}{l}\text { Tustin Community } \\
\text { No. } 1\end{array}$ & $\begin{array}{l}\text { y } 600 \mathrm{~N} \text {. and } 1,350 \text { E. of } \\
\text { SW. cor. sec. } 21 \text {, T. } 4 \\
\text { S., R. } 9 \text { W. }\end{array}$ & 271 & 2,380 & $8 / 23 / 47$ & $\begin{array}{l}\text { Aban: } \\
\text { doned } \\
9 / 12 / 47\end{array}$ & $\begin{array}{l}0 \cdot ?: \text { Alluvium } \\
\text { ?:1,678: La Habra Formation } \\
1,678 \cdot 2,332: \text { Puente Formation } \\
2,332 \cdot 2,380: \text { El Modeno Volcanics }\end{array}$ & . \\
\hline Do. & $\begin{array}{l}\text { Yorba Community } \\
\text { No. } 1\end{array}$ & $\begin{array}{l}\text { 1,150 S. and } 1,250 \text { W. of } \\
\text { NE. cor. proj. sec. } 36 \text {, } \\
\text { T. } 3 \text { S., R. } 9 \text { W. }\end{array}$ & 317 & 2,714 & $9 / 10 / 35$ & $\begin{array}{c}\text { Aban: } \\
\text { doned } \\
5 / 23 / 36\end{array}$ & $\begin{array}{l}0 \cdot ?: \text { Alluvium } \\
? \cdot 1,500 \pm: \text { Sycamore Canyon Member } \\
\text { of Puente Formation } \\
\text { 1,500 } \pm \cdot 2,714: \text { Yorba Member of } \\
\text { Puente Formation }\end{array}$ & $\begin{array}{l}\text { Redrilled } 3 \\
\text { times. }\end{array}$ \\
\hline Do. & $\begin{array}{l}\text { Zaiser-Brelje } \\
\text { Community No. }\end{array}$ & $\begin{array}{l}2,250 \mathrm{~S} \text {. and } 1,300 \mathrm{E} . \\
1 \text { of NW. cor. sec. } 17, \mathrm{~T} . \\
4 \mathrm{~S} ., \mathrm{R} .9 \mathrm{~W} .\end{array}$ & 210 & 5,045 & $6 / 21 / 27$ & $\begin{array}{c}\text { Aban- } \\
\text { doned } \\
11 / 26 / 27\end{array}$ & $\begin{array}{l}0-?: \text { Alluvium } \\
?-2,150 \pm: \text { La Habra Formation } \\
2,150 \pm \cdot 3,230: \text { Upper member of } \\
\text { Fernando Formation } \\
3,230 \cdot 3,835: \text { Puente Formation } \\
3,835 \cdot 4,340 \text { : Topanga Formation } \\
4,340-4,450: \text { Intrusive volcanic rocks } \\
\text { related to El Modeno Volcanics } \\
4,450: \text { Fault } \\
4,450 \cdot 4,740: \text { Vaqueros and Sespe } \\
\text { Formations, undifferentiated } \\
4,740.4,750: \text { Intrusive volcanic rocks } \\
\text { related to El Modeno Volcanics } \\
4,750.5,045: \text { Vaqueros and Sespe } \\
\text { Formations, undifferentiated }\end{array}$ & \\
\hline Stephens, J. J. & Susie M-1 & $\begin{array}{l}450 \mathrm{~N} . \text { and } 3,875 \mathrm{~W} . \text { of } \\
\text { SE. cor. sec. 7, T. } 5 \\
\text { S., R. } 7 \text { W. }\end{array}$ & $1,090 \pm$ & 4,363 & $12 / 16 / 55$ & $\begin{array}{l}\text { Idle } \\
1 / 59\end{array}$ & $\begin{array}{l}\text { 0.75 } 7: \text { Alluvium } \\
75 \pm \cdot 610: \text { Silverado Formation } \\
\text { 610-980: Pleasants Sandstone Member of } \\
\text { Williams Formation } \\
\text { 980-1,360: Schulz Ranch Sandstone } \\
\text { Member of Williams Formation } \\
\text { 1,360-3,575 } \pm \text { : Holz Shale Member of } \\
\text { Ladd Formation }\end{array}$ & $\begin{array}{l}\text { Also known as J. J. } \\
\text { Stephens. } \\
\text { Silverado } \\
\text { Exploration Co. } \\
\text { Susie M-1 and } \\
\text { Grandeur Ex- } \\
\text { ploration Co. } \\
\text { Susie M-1. }\end{array}$ \\
\hline
\end{tabular}




\section{WELL LOCATIONS AND RELATED DATA-CONTINUED}

[Wildcat wells. core holes, and selected producing wells drilled in the northern Santa Ana Mountains before January 1, 1959. Elevations, depths, and locations are in feet, and the operator's names are those in use in 1958)

\begin{tabular}{|c|c|c|c|c|c|c|c|c|}
\hline Operator & Well & Location & $\begin{array}{l}\text { Elev- } \\
\text { ation }\end{array}$ & $\begin{array}{l}\text { Total } \\
\text { depth }\end{array}$ & Spud & $\begin{array}{l}\text { Present } \\
\text { status }\end{array}$ & Geology & Remarks \\
\hline \multicolumn{3}{|c|}{ Stephens, J.J.-Continued } & & & & & $\begin{array}{l}\text { 3,575 } \pm-3,830 \pm: \text { Baker Canyon Conglomer- } \\
\text { ate Member of Ladd Formation } \\
3,830 \pm-4,300 \pm \text { : Trabuco Formation } \\
4,300 \pm .4,363: \text { Probably either Santiago } \\
\text { Peak Volcanics or Bedford Canyon } \\
\text { Formation }\end{array}$ & \\
\hline $\begin{array}{l}\text { Sudduth Drilling } \\
\text { Co. }\end{array}$ & $\begin{array}{l}\text { Century. Wetzel } \\
\text { No. } 18\end{array}$ & $\begin{array}{l}1,200 \mathrm{~S} . \text { and } 1,500 \mathrm{~W} \text {. } \\
\text { of NE. cor. sec. } 32, \mathrm{~T} \text {. } \\
3 \mathrm{~S} ., \text { R. } 9 \text { W. }\end{array}$ & 280 & 5.150 & $?$ & $\begin{array}{l}\text { Aban- } \\
\text { doned } \\
\text { pro- } \\
\text { ducer }\end{array}$ & $\begin{array}{l}0-?: \text { Terrace deposits } \\
?-1,450: \text { La Habra Formation } \\
\text { 1,450-2,370: Upper member of } \\
\text { Fernando Formation } \\
2,370-3,400: \text { Lower member of } \\
\text { Fernando Formation } \\
\text { 3,400-3,630: Sycamore Canyon Member } \\
\text { of Puente Formation } \\
3,630 \cdot 4,560: \text { Yorba Member of } \\
\text { Puente Formation } \\
\text { 4,560-5,150: Soquel Member of } \\
\text { Puente Formation }\end{array}$ & $\begin{array}{l}\text { In Richfield } \\
\text { oil field. }\end{array}$ \\
\hline Superior Oil Co. & Bennett No. 1 & $\begin{array}{l}1,150 \mathrm{~N} . \text { and } 2.200 \mathrm{~W} \\
\text { of SE. cor. sec. } 32, \mathrm{~T} \text {. } \\
3 \mathrm{~S} ., \mathrm{R} .9 \mathrm{~W} .\end{array}$ & 238 & 4,162 & $9 / 28 / 29$ & $\begin{array}{c}\text { Aban- } \\
\text { doned } \\
11 / 26 / 29\end{array}$ & 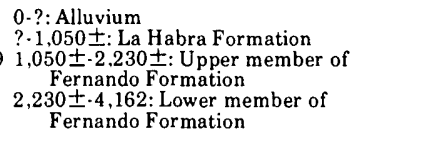 & $\begin{array}{l}\text { Driller's } \log \\
\text { only data } \\
\text { available. }\end{array}$ \\
\hline Do. & Davis No. 1 & $\begin{array}{l}1,850 \mathrm{~S} \text {. and } 2,000 \mathrm{~W} \text {. of } \\
\text { NE. cor. proj. sec. } 6, \mathrm{~T} \text {. } \\
4 \mathrm{~S} ., \mathrm{R} .9 \mathrm{~W} .\end{array}$ & 222 & 1,418 & $11 / 13 / 29$ & $\begin{array}{l}\text { Aban- } \\
\text { doned } \\
12 / 2 / 29\end{array}$ & $\begin{array}{l}0 \cdot ?: \text { Alluvium } \\
?-1,418: \text { La Habra Formation }\end{array}$ & Do. \\
\hline Do. & Schroeder No. 1 & $\begin{array}{l}150 \mathrm{~N} . \text { and } 3,250 \mathrm{E} . \text { of } \\
\text { SW. cor. sec. } 33, \mathrm{~T} .3 \\
\text { S., R. } 9 \text { W. }\end{array}$ & 255 & 4,514 & $9 / 15 / 29$ & $\begin{array}{c}\text { Aban: } \\
\text { doned } \\
10 / 27 / 29\end{array}$ & & $\begin{array}{l}\text { Driller's log only } \\
\text { data available, } \\
\text { no interpretation } \\
\text { possible. }\end{array}$ \\
\hline \multirow[t]{3}{*}{ Texas Co. } & $\begin{array}{l}\text { Bennett No. } 1 \\
\text { (Original hole) }\end{array}$ & $\begin{array}{l}1,275 \mathrm{~N} . \text { and } 2,075 \mathrm{~W} . \text { of } \\
\text { SE. cor. sec. } 32, \mathrm{~T} .3 \\
\text { S., R. } 9 \text { W. }\end{array}$ & 245 & 6,022 & $3 / 8 / 57$ & & $\begin{array}{l}0 \cdot ?: \text { Alluvium } \\
\text { ?-970: La Habra Formation } \\
970-2,210: \text { Upper member of } \\
\text { Fernando Formation } \\
2,210-3,670: \text { Lower member of } \\
\text { Fernando Formation } \\
3,670-3,910: \text { Sycamore Canyon Member } \\
\text { of Puente Formation } \\
3,910-5,600 \pm \text { : Yorba Member of } \\
\text { Puente Formation } \\
\text { 5,600 } \pm-6,022: \text { Soquel Member of } \\
\text { Puente Formation }\end{array}$ & $\begin{array}{l}\text { Bottom hole } \\
\text { coordinates: } 496 \\
\text { N. and } 701 \mathrm{~W} . \\
\text { of surface } \\
\text { location. }\end{array}$ \\
\hline & $\begin{array}{l}\text { Bennett No. } 1 \\
\quad \text { (Redrill No. 1) }\end{array}$ & & & 7,385 & & & $\begin{array}{l}? \cdot 3,910: \text { Sycamore Canyon Member } \\
\text { of Puente Formation } \\
3,910 \cdot 5,710: \text { Yorba Member of } \\
\text { Puente Formation } \\
\text { 5,710-7,385: Soquel Member of } \\
\text { Puente Formation }\end{array}$ & $\begin{array}{l}\text { Bottom hole } \\
\text { coordinates: } 307 \\
\mathrm{~N} \text {. and } 909 \mathrm{~W} \text {. of } \\
\text { surface location. }\end{array}$ \\
\hline & $\begin{array}{l}\text { Bennett No. } 1 \\
\text { (Redrill No. 2) }\end{array}$ & & & 8,298 & & $\begin{array}{l}\text { Aban- } \\
\text { doned } \\
6 / 19 / 57\end{array}$ & $\begin{array}{l}\text { ?-5.913: Yorba Member of } \\
\text { Puente Formation } \\
\text { 5,913.7,820: Soquel Member of } \\
\text { Puente Formation } \\
\text { 7,820.8,225: La Vida Member of } \\
\text { Puente Formation } \\
\text { 8,225·8,298: El Modeno Volcanics }\end{array}$ & $\begin{array}{l}\text { Bottom hole } \\
\text { coordinates: } 43 \\
\mathrm{~N} \text {. and } 1,104 \mathrm{~W} . \\
\text { of surface } \\
\text { location. }\end{array}$ \\
\hline Do. & $\begin{array}{l}\text { Carrillo Ranch } \\
(\text { NCT-1) No. } 1\end{array}$ & $\begin{array}{l}875 \mathrm{~N} . \text { and } 3,850 \text { E. of } \\
\text { SW. cor. proj. sec. } 30 \\
\text { T. } 3 \text { S., R. } 8 \text { W. }\end{array}$ & 375 & 4,507 & $6 / 16 / 53$ & $\begin{array}{c}\text { Aban. } \\
\text { doned } \\
7 / 10 / 53\end{array}$ & $\begin{array}{l}\text { 0-?: Alluvium } \\
\text { ?-1,535: Sycamore Canyon Member } \\
\text { of Puente Formation } \\
\text { 1,535-2,958: Yorba Member of } \\
\text { Puente Formation } \\
\text { 1,656-1,837: Chapman sand in Yorba } \\
\text { Member of Puente Formation } \\
\text { 2,958-3,550: Soquel Member of } \\
\text { Puente For mation } \\
\text { 3,550-4,050: La Vida Member of } \\
\text { Puente Formation } \\
\text { 4,050-4,507: Topanga Formation }\end{array}$ & \\
\hline Do. & Dowling No. 1 & $\begin{array}{l}2,350 \mathrm{~S} . \text { and } 3,050 \mathrm{E} \text {. of } \\
\text { NW. cor. proj. sec. } 31 \text {, } \\
\text { T. } 3 \text { S., R. } 9 \text { W. }\end{array}$ & 243 & 8,115 & $6 / 27 / 56$ & $\begin{array}{l}\text { Pro- } \\
\text { ducing }\end{array}$ & 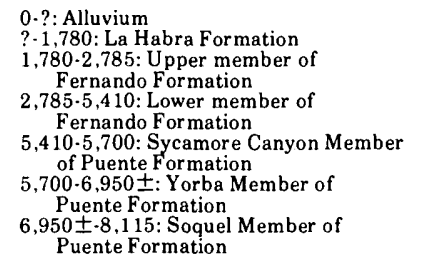 & $\begin{array}{l}\text { Lower member of } \\
\text { Fernando } \\
\text { Formation } \\
\text { believed to be } \\
\text { repeated by a } \\
\text { northwest trend. } \\
\text { ing, northeast } \\
\text { dipping, reverse } \\
\text { fault. }\end{array}$ \\
\hline Do. & Dowling No. 2 & $\begin{array}{l}2,200 \text { S. and } 3,900 \text { E. of } \\
\text { NW. cor. proj. sec. } 31 \text {, } \\
\text { T. } 3 \text { S..R. } 9 \text { W. }\end{array}$ & 244 & 8,094 & $10 / 27 / 56$ & - do. & $\begin{array}{l}\text { 0-?: Alluvium } \\
\text { ?-1,495: La Habra Formation } \\
\text { 1,495-2,545: Upper member of } \\
\text { Fernando Formation } \\
2,545 \cdot 4,650: \text { Lower member of } \\
\text { Fernando Formation } \\
4,650 \cdot 4,845: \text { Sycamore Canyon Member } \\
\text { of Puente Formation } \\
4,845 \cdot 6,650 \pm \text { : Yorba Member of } \\
\text { Puente Formation } \\
\text { 6,650 } \pm-8,094: \text { Soquel Member of } \\
\text { Puente Formation }\end{array}$ & $\begin{array}{l}\text { Lower member of } \\
\text { Fernando } \\
\text { Formation } \\
\text { believed to be } \\
\text { repeated by a } \\
\text { northwest trend. } \\
\text { ing, northeast } \\
\text { dipping, reverse } \\
\text { fault. }\end{array}$ \\
\hline
\end{tabular}




\section{WELL LOCATIONS AND RELATED DATA－CONTINUED}

[Wildcat wells, core holes, and selected producing wells drilled in the northern Santa Ana Mountains before January 1, 1959. Elevations, depths, and locations are in feet, and the operator's names are those in use in 1958

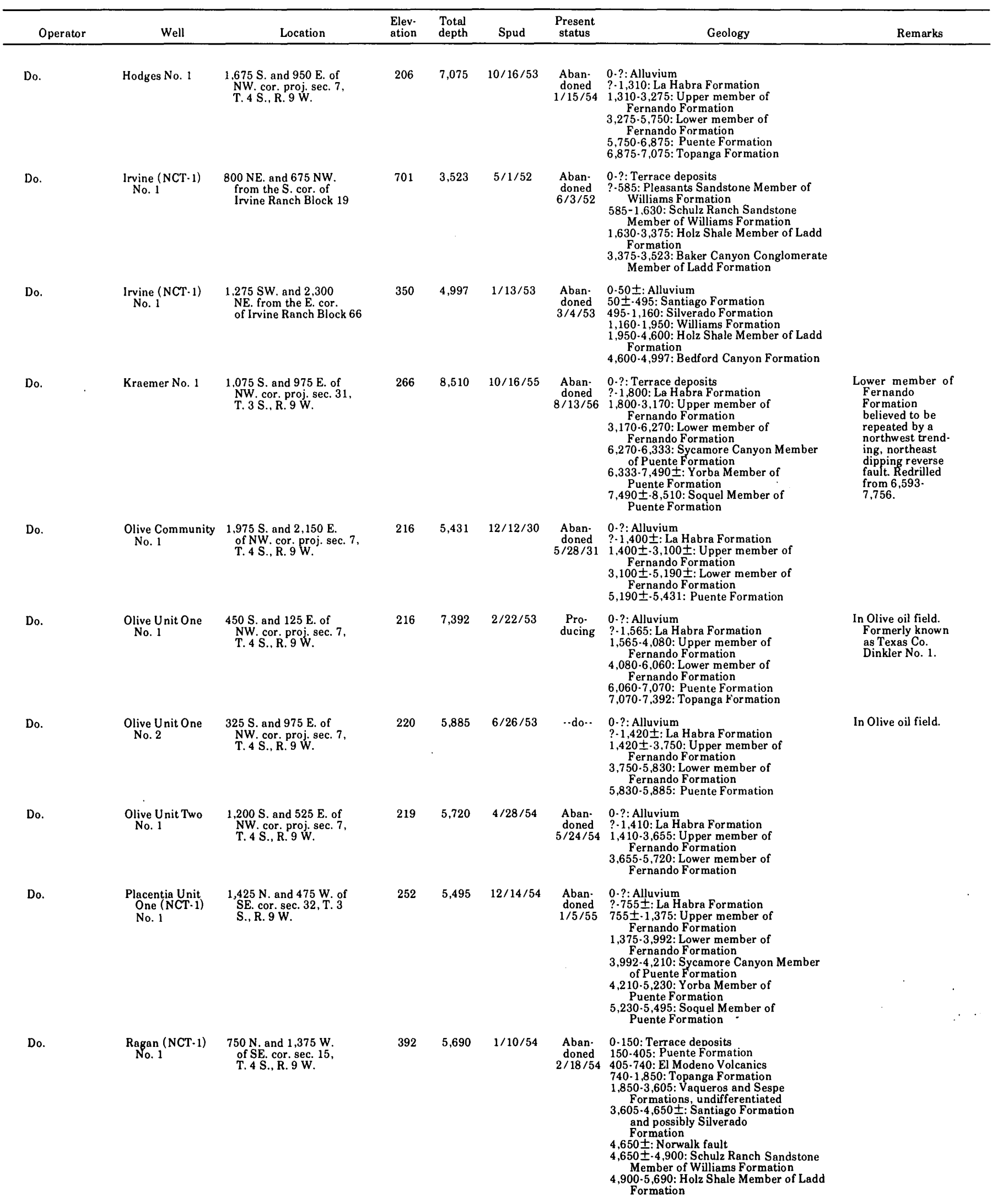




\section{WELL LOCATIONS AND RELATED DATA-CONTINUED}

[Wildcat wells, core holes, and selected producing wells drilled in the northern Santa Ana Mountains before January 1, 1959. Elevations, depths, and locations are in feet. and the operator's ames are those in use in 1958

\begin{tabular}{|c|c|c|c|c|c|c|c|c|}
\hline Operator & Well & Location & $\begin{array}{l}\text { Elev- } \\
\text { ation }\end{array}$ & $\begin{array}{l}\text { Total } \\
\text { depth }\end{array}$ & Spud & $\begin{array}{l}\text { Present } \\
\text { status }\end{array}$ & Geology & Remarks \\
\hline Do. & $\begin{array}{l}\text { Richfield } \\
\text { Consolidated } \\
\text { No. } 19\end{array}$ & $\begin{array}{l}1,950 \text { S. and } 1,100 \mathrm{~W} . \\
\text { of NE. cor. proj. sec. } \\
\text { 33, T. 3 S., R. } 9 \text { W. }\end{array}$ & 265 & 4,450 & $7 / 13 / 53$ & $\begin{array}{l}\text { Pro- } \\
\text { ducing }\end{array}$ & $\begin{array}{l}0 \cdot ?: \text { Alluvium } \\
\text { ?:770: La Habra Formation } \\
770 \cdot 1,380: \text { Upper member of } \\
\text { Fernando Formation } \\
\text { 1,380-2,180: Lower member of } \\
\text { Fernando Formation } \\
\text { 2,180-2,600: Sycamore Canyon Member } \\
\text { of Puente Formation } \\
\text { 2,600-4,240: Yorba Member of } \\
\text { Puente Formation } \\
\text { 2,770-3,840: Chapman sand in Yorba } \\
\text { Member of Puente Formation } \\
\text { 4,240-4,450: Soquel Member of } \\
\text { Puente Formation }\end{array}$ & $\begin{array}{l}\text { In Richfield oil } \\
\text { field. }\end{array}$ \\
\hline Do. & Ruff No. 1 & $\begin{array}{l}1,300 \mathrm{~N} . \text { and } 75 \mathrm{~W} . \text { of } \\
\text { SE. cor. proj. sec. } 1 \text {, } \\
\text { T. } 3 \mathrm{~S} \text {., R. } 10 \mathrm{~W} .\end{array}$ & 217 & 8,497 & $4 / 30 / 54$ & $\begin{array}{c}\text { Aban- } \\
\text { doned } \\
6 / 10 / 54\end{array}$ & 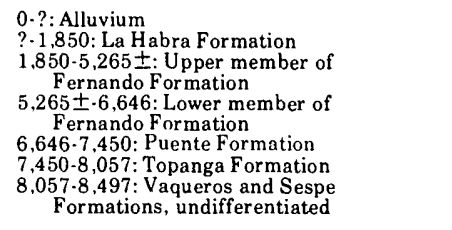 & \\
\hline Do. & Vejar No. 1 & $\begin{array}{l}2,450 \mathrm{~N} . \text { and } 1,825 \mathrm{E} . \\
\text { of SW. cor. proj. sec. } \\
35, \mathrm{~T} .3 \text { S., R. } 9 \text { W. }\end{array}$ & 327 & 3.564 & $5 / 7 / 46$ & $\begin{array}{l}\text { Aban- } \\
\text { doned } \\
6 / 5 / 46\end{array}$ & $\begin{array}{l}\text { 0.?: Terrace deposits } \\
\text { ?-530: Upper member of } \\
\text { Fernando Formation } \\
530 \cdot 1,480 \pm: \text { Lower member of } \\
\text { Fernando Formation } \\
\text { 1,480 } \pm \cdot 2,310 \pm \text { : Sycamore Canyon Member } \\
\text { of Puente Formation } \\
2,310 \pm \cdot 3,100 \pm \text { : Yorba Member of } \\
\text { Puente Formation } \\
\text { 2,425-2,650: Chapman sand in Yorba } \\
\text { Member of Puente Formation } \\
\text { 3,100 } \pm \cdot 3,564: \text { Soquel Member of } \\
\text { Puente Formation }\end{array}$ & \\
\hline Tidewater Oil Co, & Ibbetson No. 1 & $\begin{array}{l}1,225 \mathrm{~N} \text {. and } 1,125 \mathrm{E} \text {. of } \\
\text { SW. cor. proj. sec. } 35 \\
\text { T. } 3 \text { S., R. } 9 \text { W. }\end{array}$ & 280 & 3,358 & $1 / 19 / 19$ & $\begin{array}{c}\text { Aban- } \\
\text { doned } \\
1 / 10 / 20\end{array}$ & $\begin{array}{l}\text { 0-65 } \pm \text { : Alluvium } \\
65 \pm-525 \pm \text { : La Habra Formation } \\
525 \pm \cdot 1,300 \pm: \text { Upper member of } \\
\text { Fernando Formation } \\
\text { 1,300 } \pm \cdot 2,320 \pm \text { : Lower member of } \\
\text { Fernando Formation } \\
2,320 \pm-2,860 \pm \text { : Sycamore Canyon Member } \\
\text { of Puente Formation } \\
2,860 \pm-3,358 \text { : Yorba Member of } \\
\text { Puente Formation }\end{array}$ & $\begin{array}{l}\text { Formerly known } \\
\text { as Amalgamated } \\
\text { Oil Co. Ibbetson } \\
\text { No. } 1 .\end{array}$ \\
\hline Do. & $\begin{array}{l}\text { Olive-Orange } \\
\text { No. } 1\end{array}$ & $\begin{array}{l}2,100 \text { S. and } 425 \text { E. of } \\
\text { NW. cor. sec. } 19, \mathrm{~T} \text {. } \\
4 \text { S., R. } 9 \text { W. }\end{array}$ & 178 & 4,509 & $3 / 15 / 41$ & $\begin{array}{c}\text { Aban. } \\
\text { doned } \\
5 / 27 / 41\end{array}$ & $\begin{array}{l}\text { 0-?: Alluvium } \\
\text { ?-2,420: La Habra Formation } \\
\text { 2,420-3,320: Upper member of } \\
\text { Fernando Formation } \\
\text { 3,320-3,670: Lower member of } \\
\text { Fernando Formation } \\
\text { 3,670-4,108: Puente Formation } \\
\text { 4,108-4,366: Topanga Formation } \\
\text { 4,366-4,509: El Modeno Volcanics }\end{array}$ & \\
\hline Do. & Wents No. 1 & $\begin{array}{l}225 \mathrm{~S} . \text { and } 1,025 \mathrm{E} . \text { of } \\
\text { NW. cor. proj. sec. } 31 \text {, } \\
\text { T. } 3 \text { S., R. } 9 \text { W. }\end{array}$ & $260 \pm$ & 4,128 & $2 / 21$ & $\begin{array}{c}\text { Aban- } \\
\text { doned } \\
7 / 6 / 23\end{array}$ & 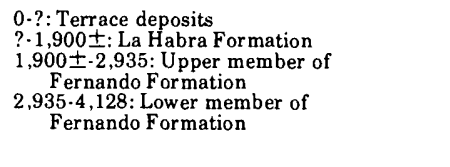 & $\begin{array}{l}\text { Driller's log only } \\
\text { data available. } \\
\text { Formerly known as } \\
\text { Placentia Pacific } \\
\text { Oil Co. and } \\
\text { Amalgamated Oil Co. } \\
\text { Wents No. } 1 .\end{array}$ \\
\hline $\begin{array}{l}\text { Trustees Develop- } \\
\text { ment Association }\end{array}$ & Well No. 1 & $\begin{array}{l}450 \text { S. and } 1,500 \text { W. of } \\
\text { NE. cor. sec. } 6 \text {, T. } 5 \\
\text { S., R. } 9 \text { W. }\end{array}$ & $185 \pm$ & 4,144 & $6 / 12 / 25$ & $\begin{array}{c}\text { Aban- } \\
\text { doned } \\
8 / 19 / 25\end{array}$ & 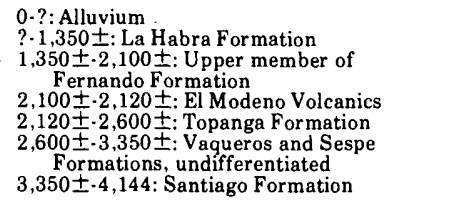 & $\begin{array}{l}\text { Driller's log only } \\
\text { data available. }\end{array}$ \\
\hline Union Oil Co. & Chapman No. 29 & $\begin{array}{l}1,325 \mathrm{~N} . \text { and } 2,550 \mathrm{~W} \\
\text { of SE. cor. sec. } 29, \mathrm{~T} \text {. } \\
3 \mathrm{~S} \text {., R. } 9 \mathrm{~W} .\end{array}$ & 290 & 10,496 & $3 / 7 / 36$ & $\begin{array}{l}\text { Pro. } \\
\text { ducing }\end{array}$ & 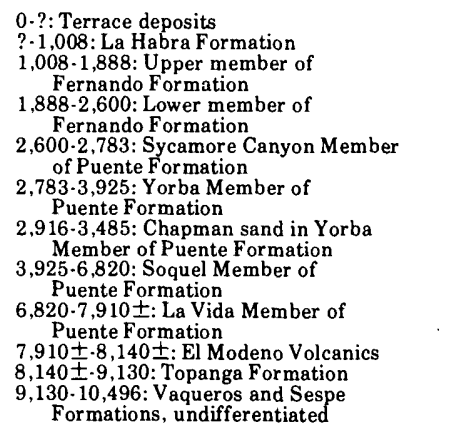 & $\begin{array}{l}\text { In Richfield oil } \\
\text { field. }\end{array}$ \\
\hline
\end{tabular}




\section{WELL LOCATIONS AND RELATED DATA-CONTINUED}

[Wildcat wells, core holes, and selected producing wells drilled in the northern Santa Ana Mountains before January 1, 1959. Elevations, depths, and locations are in feet, and the operator's names are those in use in 1958 ]

\begin{tabular}{|c|c|c|c|c|c|c|c|c|}
\hline Operator & Well & Location & $\begin{array}{l}\text { Elev- } \\
\text { ation }\end{array}$ & $\begin{array}{l}\text { Total } \\
\text { depth }\end{array}$ & Spud & $\begin{array}{l}\text { Present } \\
\text { status }\end{array}$ & Geology & Remarks \\
\hline Do. & $\begin{array}{l}\text { Olive Community } \\
\text { No. } 4 \cdot 1\end{array}$ & $\begin{array}{l}100 \text { N. and } 175 \text { E. of } \\
\text { SW. cor. sec. } 8 \text {. T. } \\
4 \text { S.. R. } 9 \text { W. }\end{array}$ & 209 & 4,236 & $9 / 6 / 48$ & $\begin{array}{l}\text { Aban- } \\
\text { doned } \\
10 / 6 / 48\end{array}$ & 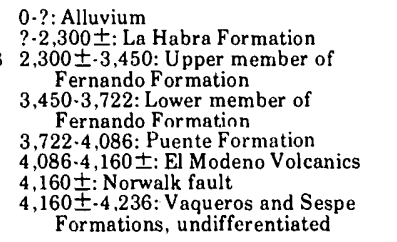 & \\
\hline Do. & Yorba No. 1 & $\begin{array}{l}950 \mathrm{~S} \text {. and } 1,000 \mathrm{~W} . \\
\text { of NE. cor. proj. sec. } \\
34, \mathrm{~T} .3 \mathrm{~S} ., \mathrm{R} .9 \mathrm{~W} .\end{array}$ & $275 \pm$ & 2,997 & $10 / 30 / 20$ & $\begin{array}{l}\text { Aban: } \\
\text { doned } \\
\quad ?\end{array}$ & & No data available. \\
\hline $\begin{array}{l}\text { Universal Con- } \\
\text { solidated Oil Co. }\end{array}$ & $\mathrm{C}$ and T No. 1 & $\begin{array}{l}1.150 \text { S. and } 4,125 \mathrm{~W} \text {. } \\
\text { of NE. cor. sec. } 5, \mathrm{~T} \text {. } \\
4 \mathrm{~S} ., \mathrm{R} .9 \mathrm{~W} .\end{array}$ & 237 & 6.969 & $11 / 11 / 47$ & $\begin{array}{c}\text { Aban- } \\
\text { doned } \\
1 / 20 / 48\end{array}$ & $\begin{array}{l}\text { 0-?: Alluvium } \\
\text { ?-1,765: La Habra Formation } \\
\text { 1,765-3,945: Upper member of } \\
\text { Fernando Formation } \\
\text { 3,945-5,540: Lower member of } \\
\text { Fernando Formation } \\
\text { 5,540-6,905: Yorba Member of } \\
\text { Puente Formation } \\
\text { 6,905.6,969: Soquel Member of } \\
\text { Puente Formation }\end{array}$ & \\
\hline \multirow[t]{2}{*}{ Do. } & $\begin{array}{l}\text { Wiley No. } 1 \\
\text { (original hole) }\end{array}$ & $\begin{array}{l}2.400 \text { S. and } 3,550 \text { W. of } \\
\text { NE. cor. sec. } 5, T .4 \text { S.. } \\
\text { R. } 9 \text { W. }\end{array}$ & 239 & 6.637 & $5 / 2 / 48$ & & $\begin{array}{l}0 \cdot ?: \text { Alluvium } \\
? \cdot 1,270: \text { La Habra Formation } \\
1,270 \cdot 2,895: \text { Upper member of } \\
\text { Fernando Formation } \\
2,895 \cdot 4,490: \text { Lower member of } \\
\text { Fernando Formation } \\
4,490-5,680 \pm \text { : Yorba Member of } \\
\text { Puente Formation } \\
5,680 \pm \cdot 6,120 \pm \text { : Soquel Member of } \\
\text { Puente Formation } \\
\text { 6,120 } 1 \cdot 6,637: \text { La Vida Member of } \\
\text { Puente Formation }\end{array}$ & \\
\hline & $\underset{(\text { redrill })}{\text { Wiley No. }} 1$ & & & 5,165 & & $\begin{array}{c}\text { Aban- } \\
\text { doned } \\
7 / 13 / 48\end{array}$ & $\begin{array}{l}\text { 1,270-2,892: Upper member of } \\
\text { Fernando For mation } \\
2,892 \cdot 4,845: \text { Lower member of } \\
\text { Fernando Formation } \\
\text { 4,845-5,165: Yorba Member of } \\
\text { Puente Formation }\end{array}$ & $\begin{array}{l}\text { Bottom hole } \\
\text { coordinates; } \\
477 \mathrm{~N} \text {. and } 277 \\
\text { W. of surface } \\
\text { location. }\end{array}$ \\
\hline $\begin{array}{l}\text { West American } \\
\text { Oil Co. }\end{array}$ & Irvine No. 1 & $\begin{array}{l}150 \mathrm{NW} \text {. and } 1,300 \\
\text { NE. from the S. cor. } \\
\text { of Irvine Ranch } \\
\text { Block } 43 \text {. }\end{array}$ & $142 \pm$ & 6.052 & $4 / 26 / 37$ & $\begin{array}{c}\text { Aban- } \\
\text { doned } \\
9 / 18 / 37\end{array}$ & $\begin{array}{l}0-?: \text { Alluvium } \\
? \cdot 1,034 \pm: \text { La Habra Formation(?) } \\
1,034 \pm \cdot 2,970 \pm \text { : Rocks of unknown age } \\
\text { and correlation } \\
2,970 \pm \cdot 3,840: \text { Williams Formation } \\
3,840-5,750 \pm \text { : Holz Shale Member of } \\
\text { Ladd Formation } \\
5,750 \pm \cdot 6,052: \text { Bedford Canyon } \\
\text { Formation (?) or Santiago } \\
\text { Peak Volcanics (?) }\end{array}$ & $\begin{array}{l}\text { Upper Cretaceous } \\
\text { fossils reported } \\
\text { in cores below } \\
3,550 \text {. Cores of } \\
\text { "basement" rock } \\
\text { described as } \\
\text { serpentine and } \\
\text { andesite, no } \\
\text { samples available. }\end{array}$ \\
\hline $\begin{array}{l}\text { Wheelock, Collins, } \\
\text { Abercrombie, and } \\
\text { Porter }\end{array}$ & Travis No. 1 & $\begin{array}{l}250 \text { S. and } 2,450 \text { E. of } \\
\text { NW. cor. proj. sec. } 31 \\
\text { T. } 3 \text { S., R. } 8 \text { W. }\end{array}$ & 342 & 3,150 & $3 / 12 / 48$ & $\begin{array}{l}\text { Aban: } \\
\text { doned } \\
1948\end{array}$ & $\begin{array}{l}0 \cdot ?: \text { Alluvium } \\
\text { ?:1,730: Sycamore Canyon Member } \\
\text { of Puente Formation } \\
\text { 1,730-3,110: Yorba Member of } \\
\text { Puente For mation } \\
\text { 1,840-2,050: Chapman sand in Yorba } \\
\text { Member of Puente Formation } \\
\text { 3,1 10-3,150: Soquel Member of } \\
\text { Puente Formation }\end{array}$ & . \\
\hline
\end{tabular}




\section{LIST OF MEGAFOSSILS LATE CRETACEOUS}

\section{LADD FORMATION}

BAKFR CANYON CONGLOMFRATE MEMBER

Fossils identified by W. P. Popenoe, 1951-54, with some nomenclatural revisions in 1977, and arranged in approximate stratigraphic order. (For locality descriptions and U.S. Geological Survey locality numbers see megafossil locality list.)

Locality F1

Pelecypods

Lima beta Popenoe

Trigonarca californica Packard

Locality F1a

Gastropods

Ampullina pseudoalveata (Packard)

Gyrodes dowelli White

Pelecypods

Ambocardia delta (Popenoe)

"Astarte" sulcata Packard

Trigonarca californica Packard

Locality F1b

Gastropods

Ampullina pseudoalveata (Packard)

Anchura cf. A. condoniana Anderson

Pelecypods

Ambocardia delta (Popenoe)

"Aphrodina" arata (Gabb)

Clisocolus corrugatus Popenoe

Cucullaea gravida (Gabb)

Glycymeris pacificus (Anderson)

Lima beta Popenoe

Pterotrigonia klamathonia (Anderson)

Locality F $1 \mathrm{c}$

Tenea sp. cf. T. inflata (Gabb), small form

Gastropod

Ampullina pseudoalveata (Packard)

Pelecypods

Crassatella gamma Popenoe

Flaventia zeta Popenoe

Glycymeris pacificus (Anderson)

Lima beta Popenoe

Liopistha anaana (Anderson)

Pterotrigonia klamathonia (Anderson)

Syncyclonema operculiformis (Gabb)

Locality F2

Trigonarca californica Packard

Gastropod

Ampullina pseudoalveata (Packard)

Pelecypods

"Astarte" sulcata Packard

Calva regina Popenoe

Trigonarca californica Packard

Locality F3

Gastropod

Cerithiid gastropod, probably n. sp.

Cephalopod

Locality F4

Otoscaphites aff. O. inermis Anderson

Gastropods

Acteonella oviformis Gabb

Anchura cf. A. condoniana Anderson
Locality F4-Continued

Pelecypods

Ambocardia delta (Popenoe)

Crassatella gamma Popenoe

Eriphyla ovoides (Packard)

Glycymeris pacificus (Anderson)

Lima beta Popenoe

Lima? sp. B

Pterotrigonia klamathonia (Anderson)

Locality F5

Syncyclonema? sp.

Gastropod

Acteonella oviformis Gabb

Pelecypod

Locality F6
Trigonarca californica Packard

Gastropod

Anchura cf. A. condoniana Anderson

Pelecypods

Pinna sp.

Syncyclonema operculiformis (Gabb)

Locality F7

Trigonarca californica Packard

Gastropods

"Alaria" nodosa (Packard)

Ampullina pseudoalveata (Packard)

Anchura cf. A. condoniana Anderson?

Cryptorhytis? sp.

Tudicla? sp.

Pelecypods

"Astarte" sulcata Packard

Calva regina Popenoe

Camptonectes? sp.

Crassatella gamma Popenoe

Cucullaea gravida (Gabb)?

Flaventia zeta Popenoe

Glycymeris pacificus (Anderson)

Gryphaea? n. sp.

Inoceramus sp. A

Inoperna bellarugosa Popenoe

Lima beta Popenoe

Liopistha anaana (Anderson)

Pleuromya? sp.

Pterotrigonia klamathonia (Anderson)

"Siphonalia" dubius Packard

Syncyclonema operculiformis (Gabb)

Trigonarca californica Packard

Cephalopod

Subprionocyclus cf. S. siskiyouensis (Anderson)

Locality F8

Pelecypods

Ambocardia (Isocardia) delta (Popenoe)

Eriphyla ovoides (Packard)

Locality F9

Lima beta Popenoe

Gastropod

Anchura cf. A. condoniana Anderson

Pelecypods

Calva regina Popenoe

Clisocolus corrugatus Popenoe

Lima beta Popenoe

Pterotrigonia klamathonia (Anderson)

Locality F10

Trigonarca californica Packard

Pelecypods

Cucullaea gravida (Gabb) 
Locality F10-Continued

Pterotrigonia klamathonia (Anderson) Spondylus? sp. B

Locality F1 1

Gastropods

Acteon politus (Gabb)

Acteonella oviformis Gabb

Ampullina pseudoalveata (Packard)

Anchura cf. A. condoniana Anderson

Pelecypods

Acila n. sp.

"Aphrodina" arata (Gabb)

Corbula sp. A

Flaventia zeta Popenoe

Meekia sp.

Parallelodon cf. P. brewerianus (Gabb)

Pterotrigonia klamathonia (Anderson)

Trigonarca californica Packard

Cephalopod

Baculites (Sciponoceras)fairbanksi Anderson

Locality F12

Pelecypods

Ostrea or Gryphaea sp.

Trigonarca californica Packard

Locality F13

Gastropods

Arichura cf. A. condoniana Anderson

Rostellinda dilleri? (White)

Pelecypods

Calva regina Popenoe

Crassatella gamma Popenoe

Cucullaea gravida (Gabb)

Opis n. sp. B

Pterotrigonia klamathonia (Anderson)

Locality F14

Trigonarca californica Packard

Gastropods

Ampullina pseudoalveata (Packard)

Anchura cf. A. condoniana Anderson

Pelecypods

Ambocardia delta (Popenoe)

"Aphrodina" arata (Gabb)

Calva regina Popenoe

Clisocolus corrugatus Popenoe

Corbula? sp.

Crassatella gamma Popenoe

Cucullaea gravida (Gabb)

Eriphyla ovoides (Packard)

Glycymeris pacificus (Anderson)

Lima beta Popenoe

Opis n. sp. B

Pleuromya? sp.

Pterotrigonia klamathonia (Anderson)

"Siphonalia" dubius Packard

Syncyclonema operculiformis (Gabb)

Tenea sp. cf. T. inflata (Gabb), small form

Trigonarca californica Packard

Cephalopods

Sciponoceras fairbanksi (Anderson)

Subprionocyclus cf. S. siskiyouensis (Anderson)

Locality F15

Pelecypods
"Aphrodina" arata (Gabb)
Crassatella gamma Popenoe
Cucullaea gravida (Gabb)
Glycymeris pacificus (Anderson)

Locality F15-Continued

Pterotrigonia klamathonia (Anderson)

Locality F16

Gastropods

Anchura cf. A. condoniana Anderson

"Siphonalia" dubius Packard

Pelecypods

Ambocardia delta (Popenoe)

"Aphrodina" arata (Gabb)

Calva regina Popenoe

Clisocolus corrugatus Popenoe

Crassatella gamma Popenoe

Cucullaea gravida (Gabb)

Lima beta Popenoe

Pterotrigonia klamathonia (Anderson)

Syncyclonema operculiformis (Gabb)

Tenea sp. cf. T. inflata (Gabb), small form

Trigonarca californica Packard

Trigonia oregana Packard

Locality F17

Gastropods

Anchura cf. A. condoniana Anderson

Pyropsis sp. A

"Siphonalia" dubius Packard

Pelecypods

Anomia? sp.

Clisocolus corrugatus Popenoe

Cucullaea gravida (Gabb)

Glycymeris pacificus (Anderson)

Lima cf. L. suciensis? Whiteaves

Opis n. sp. B

Pterotrigonia klamathonia (Anderson)

Spondylus subnodosus (Packard)

Locality F18

Trigonarca californica Packard

Gastropods

Ampullina pseudoalveata (Packard)

Arichura cf. A. condoniana Anderson

Pyropsis? sp. A

Rostellinda dilleri? (White)

Pelecypods

Calva regina Popenoe

Cucullaea gravida (Gabb)

Glycymeris pacificus (Anderson)

Lima? sp. B

Opis n. sp. B

Septifer? sp.

Spondylus? sp. A

Locality P19 = F19

Unlisted Late Cretaceous mollusks

Locality F20

Unlisted Late Cretaceous mollusks

HOLZ SHALE MEMBER

Locality F21

Gastropod

Anchura cf. A. condoniana Anderson?

Pelecypods
"Aphrodina" arata (Gabb)
Cucullaea gravida (Gabb)
Flaventia zeta Popenoe
Glycymeris pacificus (Anderson)
Lima beta Popenoe
Liopistha hardingensis (Packard) 
Locality F21-Continued Pterotrigonia klamathonia (Anderson) Syncyclonema? sp.

Cephalopod

Locality F21a Baculites sp.

Gastropod Ampullina pseudoalveata (Packard)

Pelecypods Cyprimeria moorei Popenoe Etea angulata (Packard)? Flaventia zeta Popenoe Glycymeris pacificus (Anderson)

Locality F22 Trinacria cor Popenoe

Pelecypods

Cucullaea gravida (Gabb) Glycymeris pacificus (Anderson)

Locality F23

Cephalopod

Locality F24

Baculites sp.

Pelecypods

Crassatella n. sp. cf. C. lomana Cooper, long form Glycymeris veatchii anae C. Smith

Locality F24a

Gastropods

Lysis californiensis Packard

Turritella chicoensis Gabb

Pelecypods

Cucullaea youngi Waring

Eriphyla lapidis (Packard)

Etea angulata (Packard)

Glycymeris veatchii anae $\mathrm{C}$. Smith

Parallelodon cf. $P$. vancouverensis (Meek)

Locality F24b

Pterotrigonia evansana (Meek)

Gastropod

Turritella chicoensis Gabb

Pelecypods

Eriphyla lapidis (Packard)

Glycymeris veatchii anae $\mathrm{C}$. Smith

Opis n. sp. A

Parallelodon cf. P. vancouverensis (Meek)

Locality F24c

Pterotrigonia evansana (Meek)

Gastropods

Anchura cf. A. falciformis Gabb

Biplica obliqua (Gabb)

Gyrodes canadensis Whiteaves

Tessarolax distorta? Gabb

Turritella chicoensis Gabb

Volutoderma santana Packard

Pelecypods

Crassatella cf. C. tuscana Gabb

Cucullaea youngi Waring

Eriphyla lapidis (Packard)

Glycymeris veatchii anae C. Smith

Parallelodon cf. $P$. vancouverensis (Meek)

Pterotrigonia evansana (Meek)

Cephalopod

Canadoceras cf. C. multisulcatum (Whiteaves)

Locality F24d

Gastropods

Ampullina packardi Popenoe
Locality F24d-Continued

Biplica obliqua $\mathrm{Gabb}$

Euspira n. sp. cf. E. shumardiana (Gabb)

Lysis californiensis Packard

Perissitys brevirostris (Gabb)

Turritella chicoensis Gabb

Pelecypods

Acila demessa Finlay

Clisocolus cordatus Whiteaves

Crassatella n. cf. C. lomana Cooper, long form

Cucullaea youngi Waring

Cymbophora angulata (Waring)

Etea angulata (Packard)

Flaventia lens (Gabb)

Glycymeris veatchii (Gabb), giant form

Glycymeris veatchii anae C. Smith

Locality F25

Trinacria cor Popenoe

Cephalopod

Pachydiscus? sp. A

Locality F26

Gastropods

Ampullina packardi Popenoe

Turritella chicoensis Gabb

Volutoderma santana Packard

Pelecypods

Crassatella n. sp. cf. C. lomana Cooper, long form Glycymeris veatchii anae C. Smith Pterotrigonia evansana (Meek)

Locality F27 Tenea inflata (Gabb), large form

Locality F28

Cephalopod

Páchydiscus? sp.

Pelecypod

Acila demessa Finlay?

Cephalopod

Locality F29

Lytoceras? sp.

Gastropods

Biplica obliqua (Gabb)

Turritella chicoensis Gabb

Pelecypods

Crassatella cf. C. tuscana Gabb

Cucullaea youngi Waring

Eriphyla ovoides (Packard)

Glycymeris veatchii anae C. Smith?

Opis n. sp. A

Parallelodon cf. $P$. vancouverensis (Meek)

Pterotrigonia evansana (Meek)

Tenea inflata $(\mathrm{Gabb})$, large form

Cephalopod

Locality F30

Baculites sp.

Gastropods

Anchura? sp.

Turritella chicoensis Gabb

Pelecypods

Crassatella cf. C. tuscana Gabb

Flaventia lens (Gabb)

Glycymeris veatchii anae C. Smith?

Opis n. sp. A

Parallelodon cf. P. vancouverensis( Meek)

Pterotrigonia evansana (Meek) 
Locality F31

Gastropod

Turritella chicoensis Gabb

Pelecypods

Calva bowersiana (Cooper)?

Crassatella n. sp. cf. C. lomana Cooper, long form

Cucullaea youngi Waring

Flaventia lens (Gabb)

Pterotrigonia evansana (Meek)

Locality F32

Yaadia tryoniana (Gabb)

Gastropods

Biplica obliqua (Gabb)

Euspira n. sp. cf. E. shumardiana (Gabb)

Turritella chicoensis Gabb

Pelecypods

Meekia n. sp. A

Locality F33

Pterotrigonia evansana (Meek)

Gastropod

Ampullina packardi Popenoe

Pelecypods

Etea angulata (Packard)

Inoceramus cf. I. whitneyi (Gabb)

Locality F34

Pterotrigonia evansana (Meek)

Gastropod

Pelecypods

Turritella chicoensis Gabb

Glycymeris veatchii anae $\mathrm{C}$. Smith

Parallelodon cf. P. vancouverensis (Meek)

Locality F34a

Pterotrigonia evansana (Meek)

Gastropods

Euspira n. sp. cf. E. shumardiana (Gabb)

Turritella chicoensis Gabb, typical form

Volutoderma santana Packard

Pelecypods

Crassatella cf. C. tuscana Gabb

Cucullaea youngi Waring

Etea angulata (Packard)

Flaventia lens (Gabb)

Glycymeris veatchii anae $\mathrm{C}$. Smith

Opis n. sp. A

Parallelodon cf. $P$. vancouverensis (Meek)

Pterotrigonia evansana (Meek)

Locality F34b

Tenea inflata (Gabb), large form

Gastropods

Turritella chicoensis Gabb

Volutoderma santana Packard

Pelecypods

Clisocolus cordatus Whiteaves

Opis n. sp. A

Locality F34c

Parallelodon cf. P. vancouverensis(Meek)

Gastropods

Biplica obliqua (Gabb)

Euspira n. sp. cf. E. shumardiana (Gabb)

Lysis californiensis Packard

Turritella chicoensis Gabb

Volutoderma santana Packard

Pelecypods

Acila demessa Finlay

Clisocolus cordatus Whiteaves

Crassatella n. sp. cf. C. lomana Cooper, long form
Locality F34 c-Continued

Cucullaea youngi Waring

Cymbophora angulata (Waring)

Cymbophora popenoei Saul

Flaventia lens (Gabb)

Glycymeris veatchii (Gabb), giant form

Glycymeris veatchii anae C. Smith

Pterotrigonia evansana (Meek)

Locality F34d

Trinacria cor Popenoe

Gastropods

Euspira n. sp. cf. E. shumardiana (Gabb)

Lysis californiensis Packard

Perissitys brevirostris (Gabb)

Volutoderma santana Packard

Pelecypods

Acila demessa Finlay

Clisocolus cordatus Whiteaves

Crassatella n. sp. cf. C. lomana Cooper, long form

Cucullaea youngi Waring

Cymbophora angulata (Waring)

Flaventia lens (Gabb)

Glycymeris veatchii (Gabb), giant form

Glycymeris veatchii anae $\mathrm{C}$. Smith

Locality F35

Trinacria cor Popenoe

Pelecypod

Locality F36

Flaventia lens (Gabb)

Gastropods

Turritella chicoensis Gabb

Volutoderma cf. V. averillii (Gabb)

Pelecypods

Calva bowersiana (Cooper)

Crassatella n. sp. A

Cucullaea youngi Waring

Glycymeris veatchii anae C. Smith?

Pterotrigonia evansana (Meek)

"Tellina" cf. T. longa (Gabb)

WILLIAMS FORMATION

SCHULZ RANCH SANDSTONE MEMBER

Locality F37 (Redeposited blocks of Baker Canyon Conglomerate in basal Schulz Ranch Sandstone)

Gastropods

Acteonella oviformis Gabb?

Ampullina pseudoalveata (Packard)

Potamides? sp.

Pelecypods

"Astarte" sulcata Packard

Glycymeris pacificus (Anderson)?

Pteria n. sp.

Locality F38

Trigonocallista regina (Popenoe)

Gastropod

Pelecypods

Trajanella $\mathrm{n} . \mathrm{sp}$.

Clisocolus cordatus Whiteaves

Coralliochama n. sp.

Crassatella n. sp. cf. C. lomana Cooper, long form

Cucullaea youngi Waring

Eriphyla lapidis (Packard)

Etea angulata (Packard)

Gervillia sp.

Glycymeris veatchii ( $\mathrm{Gabb}$ ), giant form 
Locality F38-Continued

Opis n. sp. A

Pachycardium coronaense (Packard)

Pterotrigonia evansana (Meek)

Septifer? sp.

Locality F39

Spondylus subnodosus (Packard)

Gastropod

Pelecypods

Margarites ornatissimus (Gabb)

Acila demessa Finlay

Calva bowersiana (Cooper)

Coralliochama n. sp.

Crassatella n. sp. cf. C. lomana Cooper, long form

Cucullaea youngi (Waring)

Eriphyla lapidis (Packard)

Glycymeris veatchii (Gabb), giant form

Opis n. sp. A

Pachycardium coronaense (Packard)

Locality F40

Pterotrigonia evansana (Meek)

Gastropods

Ampullina packardi Popenoe

Epitonium? sp.

Lysis californiensis Packard

Turritella chicoensis Gabb

Turritella ossa Popenoe

Volutoderma santana Packard?

Pelecypods

Acila demessa Finlay

Corbula? sp.

Crassatella n. sp. cf. C. lomana Cooper, long form Glycymeris veatchii anae $\mathrm{C}$. Smith

Locality F4

Trinacria cor Popenoe

Gastropods

Ampullina packardi Popenoe

Ampullina? n. sp. A

Biplica obliqua (Gabb)

Lysis californiensis Packard

Turritella chicoensis Gabb

Pelecypods

Acila demessa Finlay

Calva bowersiana (Cooper)

Crassatella n. cf. C. lomana Cooper, long form

Cymbophora angulata (Waring)

Flaventia lens (Gabb)

Glycymeris veatchii anae C. Smith

Pterotrigonia evansana (Meek)

Trinacria cor Popenoe

Locality F42

Cephalopod

Locality F43

Pachydiscus sp.

Gastropods

Lysis californiensis Packard

Volutoderma santana Packard

Pelecypods

Crassatella cf. C. tuscana Gabb

Eriphyla ovoides (Packard)

Flaventia lens (Gabb)

Pterotrigonia evansana (Meek)

Trinacria cor Popenoe
PLEASANTS SANDSTONE MEMBER

Locality F44

Gastropods

Ampullina packardi Popenoe

Biplica obliqua (Gabb)

Euspira n. sp. cf. E. shumardiana (Gabb)

Gyrodes expansa canadensis Whiteaves

Lysis californiensis Packard

Perissitys brevirostris (Gabb)

Turritella pescaderoensis Arnold

Volutoderma magna Packard

Pelecypods

Anomia cf. A. lineata Gabb

Calva bowersiana (Cooper)

Camptonectes? n. sp.

Clisocolus cordatus Whiteaves

Crassatella n. sp. A

Cucullaea youngi Waring

Flaventia lens (Gabb)

Glycymeris veatchii anae C. Smith

Ostrea sp.

Pachycardium coronaense (Packard)

Panope californica Packard

Parallelodon cf. P. vancouverensis (Meek)

Pinna sp. A

Pterotrigonia evansana (Meek)

Spondylus subnodosus (Packard)

Tenea inflata (Gabb), large variety

Yaadia tryoniana (Gabb)

Cephalopods

Baculites sp.

Eutrephoceras sp. A

Eutrephoceras sp. B

Metaplacenticeras pacificum (J. P. Smith)

Pachydiscus? cf. P. peninsularis Anderson and Hanna

Locality F45

Pächydiscus? sp.

Gastropods

Euspira n. sp. cf. E. shumardiana (Gabb)

Turritella ossa Popenoe

Turritella pescaderoensis Arnold

Pelecypods

Crassatella n. sp. cf. C. lomana Cooper, long form

Locality F46

Glycymeris veatchii anae C. Smith

Pelecypods

Calva bowersiana (Cooper)

Cymbophora popenoei Saul

"Lutraria" truncata? Gabb

Locality F47

Cephalopod

Locality F48

Metaplacenticeras pacificum (J.P. Smith)

Gastropod

Biplica obliqua (Gabb)

Pelecypods

Acila demessa Finlay

Clisocolus cordatus Whiteaves

Cymbophora popenoei Saul

Locality F49

Gastropods

Turritella pescaderoensis Arnold

Volutoderma cf. V. averillii (Gabb) 
Locality F49-Continued

Pelecypods

Crassatella n. sp. cf. C. lomana Cooper, long form

Cucullaea youngi (Waring)

Glycymeris veatchii anae C. Smith

Cephalopods

Nostoceras? aff. N. sternbergi Anderson and Hanna

Locality F50

Pelecypods

Acila demessa Finlay?

Calva bowersiana (Cooper)

Clisocolus cordatus Whiteaves

Cymbophora popenoei Saul

Glycymeris veatchii anae C. Smith

Legumen ooides ( $\mathrm{Gabb}$ )

Locality F51

Pterotrigonia evansana (Meek)

Gastropods

Biplica obliqua (Gabb)

Turritella pescaderoensis Arnold

Pelecypods

Calva bowersiana (Cooper)

Clisocolus cordatus Whiteaves

Cucullaea youngi Waring

Cymbophora popenoei Saul

Glycymeris veatchii anae $\mathrm{C}$. Smith

Pachycardium coronaense (Packard)

Locality F52

Trinacria cor Popenoe

Cephalopod

Metaplacenticeras pacificum (J. P. Smith)

Locality F53

Cephalopod

Locality F54

Metaplacenticeras pacificum (J. P. Smith)

Cephalopod

Metaplacenticeras pacificum (J. P. Smith)

Locality F55

Gastropod

Volutoderma magna Packard

Pelecypods

Crassatella n. sp. cf. C. lomana Cooper, long form Parallelodon cf. $P$. vancouverensis (Meek)

Cephalopod

Locality F56

Metaplacenticeras pacificum (J. P. Smith)?

Gastropod

Turritella pescaderoensis Arnold

Pelecypods

Acila demessa Finlay

Crassatella cf. C. tuscana Gabb

Locality F57

Gastropod

Biplica obliqua (Gabb)

Pelecypods

Clisocolus cordatus Whiteaves

Cucullaea youngi Waring

Cymbophora popenoei Saul

Glycymeris veatchii anae C. Smith

Inoceramus sp. A

Parallelodon cf. $P$. vancouverensis (Meek)

Locality F58

Pterotrigonia evansana (Meek)

Pelecypods

Calva bowersiana (Cooper)?
Locality F58-Continued

Clisocolus cordatus Whiteaves

Cymbophora angulata (Waring)

Flaventia lens (Gabb)

Parallelodon cf. P. vancouverensis (Meek)

Pterotrigonia evansana (Meek)

Locality F59

Tenea inflata (Gabb), large form

Locality F60

Gastropod

Volutoderma magna Packard

Gastropod

Volutoderma? sp.

Pelecypods

Calva bowersiana (Cooper)

Cymbophora popenoei Saul

Glycymeris veatchii anae C. Smith

Pterotrigonia evansana (Meek)

Cephalopod

Locality F61

Metaplacenticeras californicum? (Anderson)

Gastropod

Biplica obliqua (Gabb)

Pelecypods
Cucullaea youngi Waring
Cymbophora angulata (Waring)

Pterotrigonia evansana (Meek)

Locality F62

Gastropods

Biplica obliqua (Gabb)

Gyrodes canadensis Whiteaves

Pelecypods

Calva bowersiana (Cooper)

Clisocolus cordatus Whiteaves

Cucullaea youngi Waring

Cymbophora angulata (Waring)

Cymbophora popenoei Saul

Flaventia lens (Gabb)

Glycymeris veatchii anae C. Smith

Pterotrigonia evansana (Meek)

Spondylus subnodosa (Packard)

Cephalopods

Metaplacenticeras pacificum (J.P. Smith)

Puzosia ("Latidorsella") cf. P. ("L.")

selwyniana Whiteaves

Locality F63

Gastropod

Volutoderma magna Packard

Pelecypods

Cucullaea youngi Waring

Locality F64

Glycymeris veatchii (Gabb), giant form

Pelecypods

Clisocolus cordatus Whiteaves

Crassatella cf. C. tuscana Gabb

Cucullaea youngi Waring

Cephalopod

Locality F65

Pàchydiscus? sp. B

Cephalopod

Puzosia ("Latidorsella") cf. P. ("L.") selwyniana Whiteaves

Locality F66

Pelecypod

Spondylus subnodosus (Packard) 
Locality F67

Cephalopod

Locality F68

Metaplacenticeras pacificum (J. P. Smith)

Pelecypods

Calva bowersiana ( Cooper)

Clisocolus cordatus Whiteaves?

Cucullaea youngi Waring

Locality F69

Cymbophora angulata (Waring)

Gastropods

Atira ornatissima (Gabb)

Biplica obliqua (Gabb)

Gyrodes canadensis Whiteaves

Pelecypods

Inoceramus sp. A

Pinna sp. A

Pterotrigonia evansana (Meek)

Cephalopods

Metaplacenticeras pacificum (J. P. Smith)

Nostoceras? sp. A

Puzosia ("Latidorsella") cf. P. ("L.") selwyniana Whiteaves

Locality F70

Gastropod

Cerithium? suciaensis Packard

Pelecypods

Clisocolus cordatus Whiteaves

Crassatella n. sp. A

Glycymeris veatchii anae C. Smith

Parallelodon cf. P. vancouverensis (Meek)

Pterotrigonia evansana (Meek)

Cephalopod

Locality F71

Metaplacenticeras pacificum (J.P. Smith)

Gastropods

Biplica obliqua (Gabb)

Gyrodes canadensis Whiteaves

Perissitys brevirostris (Gabb)

Turritella pescaderoensis Arnold

Pelecypods

Calva bowersiana (Cooper)

Clisocolus cordatus Whiteaves

Cucullaea? sp.

Cymbophora angulata (Waring)

Flaventia lens (Gabb)

Glycymeris veatchii anae C. Smith

Pterotrigonia evansana (Meek)

Tenea inflata (Gabb), large form

Trinacria cor Popenoe

Locality F71a

Gastropods

"Fulgur" hilgardi White

Volutoderma cf. V. averillii (Gabb)

Pelecypods

Calva bowersiana (Cooper)

Clisocolus cordatus Whiteaves

Cymbophora angulata (Waring)

Cymbophora popenoei Șaul

Glycymeris veatchii (Gabb), giant form

Glycymeris veatchii anae C. Smith

Pterotrigonia evansana (Meek)

Cephalopod

Metaplacenticeras pacificum (J.P. Smith)
Locality F71b

Gastropods

Atira ornatissima (Gabb)

Biplica obliqua (Gabb)

"Fulgur" hilgardi White

Gyrodes expansa canadensis Whiteaves

Odostomia santana Packard

Volutoderma cf. V. averillii (Gabb)

Pelecypods

Acila demessa Finlay

Calva bowersiana (Cooper)

Clisocolus cordatus Whiteaves

Crassatella n. sp. A?

Cymbophora angulata (Waring)

Cymbophora popenoei Saul

Flaventia lens (Gabb)

Glycymeris veatchii anae C. Smith

Legumen ooides ( $\mathrm{Gabb}$ )

Meekia sp. A

Pterotrigonia evansana (Meek)

Trinacria cor Popenoe

Cephalopod

Locality F72

Metaplacenticeras pacificum (J.P. Smith)

Locality F73

Cephalopod

Metaplacenticeras pacificum (J. P. Smith)

Cephalopod

Locality F74

Metaplacenticeras pacificum (J. P. Smith)

Cephalopod

Locality F75

Metaplacenticeras pacificum (J. P. Smith)

Cephalopod

Locality F76

Metaplacenticeras pacificum (J. P. Smith)

Locality F77

Metaplacenticeras pacificum (J. P. Smith)

Cephalopod

Locality F78

Metaplacenticeras pacificum (J.P. Smith)

Gastropod

Volutoderma magna Packard

Pelecypod

Cucullaea youngi (Waring)

Cephalopod

Metaplacenticeras pacificum (J. P. Smith)

Locality F79

Cephalopod

Locality F80

Baculites sp.

Gastropods

Turritella pescaderoensis Arnold

Volutoderma magna Packard

Pelecypod

Clisocolus cordatus Whiteaves

Cephalopods

Metaplacenticeras pacificum (J.P. Smith)

Locality F80a

Pachydiscus? sp.

Cephalopod

Locality F81

Metaplacenticeras pacificum (J.P. Smith)

Pelecypods 
Locality F81-Continued

Crassatella n. sp. A

Glycymeris veatchii anae C. Smith?

Panope californica Packard?

Locality F82

Cephalopod

Hamites? sp.

Gastropods

Atira ornatissima (Gabb)

Biplica obliqua (Gabb)

Gyrodes expansa canadensis Whiteaves

Pelecypods

Turritella pescaderoensis Arnold

Calva bowersiana (Cooper)

Lembulus? cf. L. striatula Forbes

Cephalopod Pterotrigonia evansana (Meek)

Metaplacenticeras pacificum (J. P. Smith)

\section{PALEOCENE}

\section{SILVERADO FORMATION}

Fossils identified by Ralph Steward, 1954, 1955, and Ellen J. Moore, 1959. (For locality descriptions and U.S. Geological Survey locality numbers see megafossil locality list.)

Locality F83

Gastropod

Locality F84

Turritella pachecoensis Stanton, strongly noded form

Gastropod

Locality F85

Turritella cf. T. pachecoensis Stanton

Gastropods

Brachysphingus? sp.

Ficopsis sp.

"Turricula" calafia Nelson

Turritella pachecoensis Stanton?

Pelecypods

Crassatella n. sp. A

Cucullaea? cf. C. mathewsonii Gabb

Locality F86

Glycymeris cf. G. veatchii major (Stanton)

Gastropods

Amaurellina sp.

Ancilla sp.

Calyptraea diegoana (Conrad)

Conus sp.

Cylichnina cf. C. tantilla (Anderson and Hanna)

Ectinochilus (Cowlitzia) sp.

Ficopsis sp.

Homalopoma? cf. H. wattsi (Dickerson)

Polinices (Polinices)? cf. P. (P.) horni Gabb

Pseudoliva? sp.

Pseudoperissolax sp.

Scaphander (Mirascapha) costatus (Gabb)

Turritella pachecoensis Stanton?

Turritella pachecoensis Stanton, strongly noded form Pelecypods

Brachidontes cf. B. lawsoni (Nelson)

Corbula cf. C. tomulata M. A. Hanna

Cucullaea? cf. C. mathewsonii Gabb
Locality F86-Continued

Glycymeris cf. G. veatchii major (Stanton)

Macrocallista? sp.

Miltha (Plastomiltha?) n. sp.?

Nuculana cf. N. gabbii (Gabb)

Pitar? cf. P. uvasana (Conrad)

Locality F87

Unidentified cardiid

Gastropods

Cylichnina sp.

Turritella cf. T. pachecoensis Stanton

Pelecypods

Corbicula? sp.

Locality F88

Crassatella? sp.

Gastropods

Streptolathyrus? sp.

Turritella pachecoensis Stanton, strongly noded form Pelecypods

Claibornites? cf. C. turneri (Stanton)

Glycymeris cf. G. veatchii major (Stanton)

Pitar? cf. P. stantoni (Dickerson)

Locality F89

Gastropods

Turritella cf. T. pachecoensis Stanton

Whitneyella? sp.

Pelecypods

Brachidontes cf. B. lawsoni (Nelson)

Tellina cf. T. remondii Gabb

Unidentified nuculanid

Locality F90

Gastropod

Turritella páchecoensis Stanton, strongly noded form? Pelecypod

Locality F91

Pitar? cf. P. uvasana (Conrad)

Gastropod

Locality F92

Turritella pachecoensis Stanton?

Gastropods

Polinices (Polinices)? cf. P. (P.) hornii Gabb

Turritella pachecoensis Stanton

$\because$ Pelecypods

Brachidontes sp.

Callista? (Costacallista?) cf. C. (C.) hornii (Gabb)

Claibornites? turneri (Stanton)

Crassatella unioides (Stanton)

Glycymeris cf. G. veatchii major (Stanton)

Locality F93

Nuculana cf. N. gabbii (Gabb)

Gastropods

Polinices (Polinices) cf. P. (P.) hornii Gabb

Turritella páchecoensis Stanton, strongly noded form Pelecypods

Callista? (Costacallista?) cf. C. (C.) hornii (Gabb)

Crassatella unioides (Stanton)

Cucullaea? cf. C. mathewsonii Gabb

Locality F94

Gastropod

Turritella pachecoensis. Stanton, strongly noded form?

Pelecypods

Crassatella sp.

Ostrea sp. 
Locality F95

Gastropods

Turritella pachecoensis Stanton?

Turritella pachecoensis Stanton, strongly noded form Unidentified naticid

Pelecypods

Cucullaea? cf. C. mathewsonii Gabb

Pitar? cf. P. stantoni (Dickerson)

Locality F96 (identified by J. G. V.edder)

Gastropods

Polinices (Polinices)? cf. P. (P.) hornii Gabb

Turritella cf. T. pachecoensis Stanton

Pelecypods

Brachidontes sp.

Callista (Costacallista) cf. C. (C.) hornii (Gabb)

Calorhadia? sp.

Claibornites? cf. C. turneri (Stanton)

Glycymeris cf. G. veatchii major (Stanton)

Locality F97

Pitar cf. P. stantoni (Dickerson)

Pelecypods

Mytilus? sp.

Locality F98

Polymesoda? sp.

Locality F99

Pelecypod

Ostrea sp.

Gastropod

Pelecypods

Goniobasis? sp.

Mytilus sp.

Polymesoda cf. P. tenuis (Gabb)

EOCENE

\section{SANTIAGO FORMATION}

Fossils identified by Ralph Stewart, 1954, 1955, and Ellen J. Moore, 1959, with nomenclatural alterations by C. R. Givens, 1977. (For locality descriptions and U.S. Geological Survey locality numbers see megafossil locality list.)

Locality F99a

Gastropods

Cylichnina? cf. C. tantilla (Anderson and Hanna)

Turritella sp.

Pelecypods

Acanthocardia? (Schedocardia?) cf. A. (S) brewerii (Gabb)

Brachidontes? cf. B. cowlitzensis (Weaver and Palmer)

Pitar? sp.

Tellina cf. T. soledadensis M. A. Hanna

Locality F99b (identified by J. G. Vedder)

Gastropod

Turritella uvasana Conrad, subsp.? cf.T. uvasana applinae Hanna

Locality F100

Gastropods

Bittium cf. B. alternatum (Gabb)

Conus cf. C. remondii Gabb

Ectinochilus (Cowlitzia) cf.E. (C.) supraplicatus (Gabb)

Ficopsis cooperiana Stewart
Locality F100-Continued

Ficopsis remondii crescentensis Weaver and Palmer

Fusimitra? cf. F. simplicissima (Cooper)

Lyrosurcula? n. sp.?

Pseudoperissolax sp. cf. P. blakei praeblakei (Vokes)

Protosurcula? sp.

Scaphander (Mirascapha) cf. S. (M.) costatus (Gabb)

Turritella uvasana Conrad, subsp.? cf. T. uvasana Pelecypods applinae Hanna

Brächidontes cf. B. cowlitzensis (Weaver and Palmer)

Nemocardium linteum (Conrad)

Ostrea sp.

Pitar? sp.

Thracia cf. T. sorrentoensis M. A. Hanna

Venericardia (Pacificor) cf. V. (P.) hornii (Gabb)

Locality F101

Gastropods

Pachycrommium? cf. P. clarki Stewart

Pseudoperissolax? sp.

Pelecypod

Unidentified lucinid?

Locality F102 (identified by J. G. Vedder)

Gastropods

Bittium alternatum (Gabb)

Bonnellitia cf. B. paucivaricata (Gabb)

Calyptraea diegoana (Conrad)

Conus remondii $\mathrm{Gabb}$

Cylichnina cf. C. tantilla (Anderson and Hanna)

Ectinochilus (Cowlitzia) cf. E. (C.) supraplicatus (Gabb)

Eocernina cf. E. hannibali (Dickerson)?

Euspira nuciformis (Gabb)

Ficopsis remondii crescentensis Weaver and Palmer

Galeodea sp.

Perse sinuata (Gabb)

Pleurofusia? sp.

Pseudoperissolax blakei (Conrad)

Turritella buwaldana Dickerson.

Pelecypods

Corbula sp.

Glycymeris cf. G.sagittata (Gabb)?

Miltha sp.

Pitar (Calpitaria) cf. P. (C.) uvasanus (Conrad)

Locality F103

Venericardia (Venericor) sp.?

Gastropod

Turritella $\mathrm{cf}$. T. buwaldana Dickerson

Pelecypod

Venericardia sp.

Locality F104

Gastropods

Ancilla cf. A.gabbi (Cossman)

Ectinochilus (Cowlitzia) cf. T. (C.) supraplicatus (Gabb)

Ficopsis remondii crescentensis Weaver and Palmer

Molopophorus antiquatus (Gabb)

Pachycrommium clarki Stewart

Scaphander (Mirascapha) costatus (Gabb)

Sinum obliquum (Gabb)

Tejonia cf. T. lajollaensis (Stewart)

Turritella cf. T. buwaldana Dickerson

Pelecypods

Acanthocardia (Schedocardia?) cf. A. (S) brewerii (Gabb)

Brachidontes cf. B. cowlitzensis (Weaver and Palmer) 


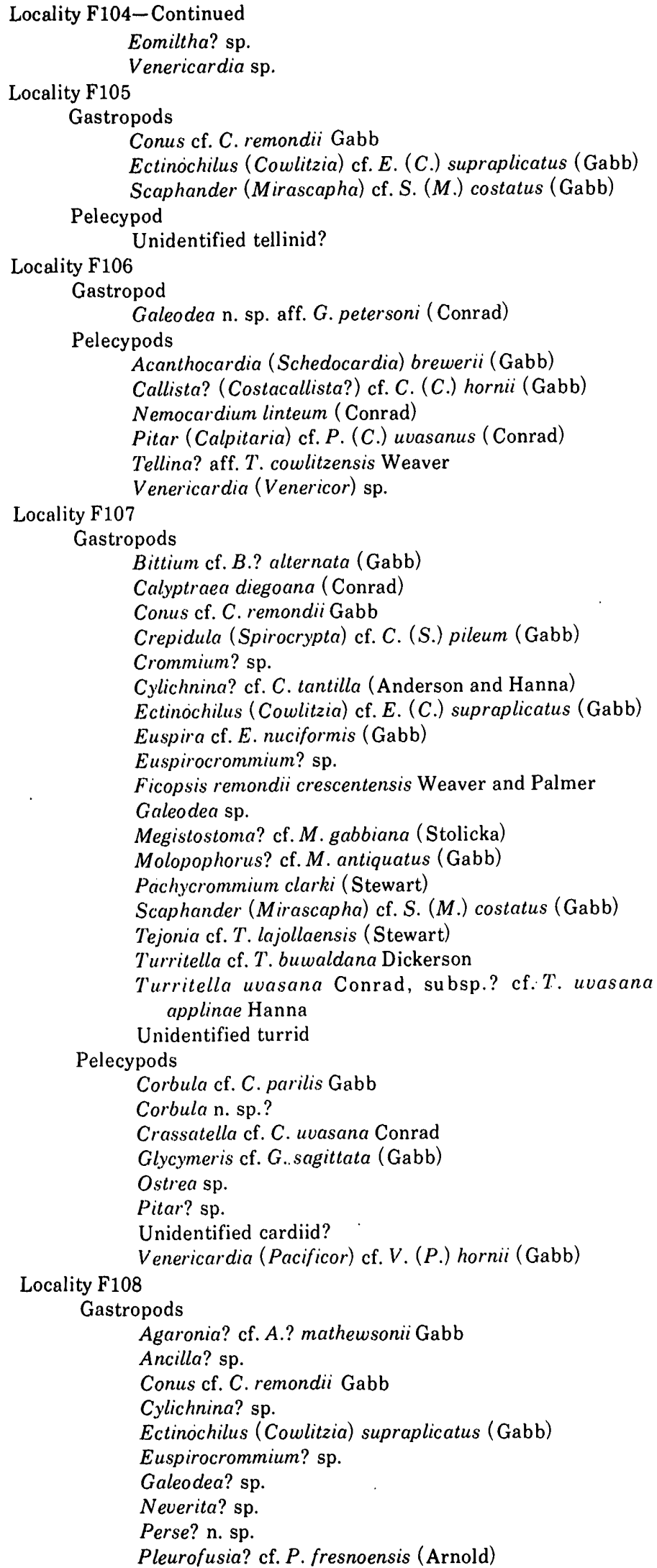

Locality F108-Continued

Pseudoliva cf. $P$. inornata Dickerson

Scaphander (Mirascapha) costatus (Gabb)

Tejonia cf. T. lajollaensis (Stewart)

Turritella cf. T. buwaldana Dickerson

Xenophora? cf. X. stocki Dickerson

Pelecypods

Acanthocardia (Schedocardia?) sp.

Glycymeris? sp.

"Nuculana" cf. "N." gabbii (Gabb)

Locality F109

Pitar? (Calpitaria?) cf. P. (C.) uvasana (Conrad)

Gastropods

Calyptraea cf. C. diegoana (Conrad)

Coalingodea tuberculiformis (Hanna)

Conus cf. C. remondii Gabb

Ficopsis remondii crescentensis Weaver and Palmer

Pseudoperissolax cf. P. blakei praeblakei (Vokes)

Tejonia cf. T. lajollaensis (Stewart)

Turritella $\mathrm{cf}$. T. buwaldana Dickerson

Pelecypods

Acanthocardia? (Schedocardia?) sp.

Brachidontes cf. B. cowlitzensis (Weaver and Palmer) Corbula sp.

Nemocardium cf. $N$. linteum (Conrad)

Pitar? (Calpitaria?) cf. P. (C.) campi Vokes

Locality F110 Tellina cf. T. soledadensis M. A. Hanna

Gastropod

Molopophorus? cf. M. antiquatus (Gabb)

Pelecypods

Acanthocardia? (Schedocardia?) cf. A. S. brewerii (Gabb)

Corbula cf. C. parilis Gabb

Locality F111

Pitar? (Calpitaria?) cf. P. (C.) campi Vokes

Pelecypod

Ostrea sp.

Locality F112 (identified by J. G. Vedder)

Gastropods

Cylichnina? sp.

Ranellina? sp.

Turritella buwaldana Dickerson

Pelecypods

Acanthocardia (Schedocardia) brewerii (Gabb)?

Pitar? sp.

?Spisula merriami Packard

Volsella? sp.

Locality F113 (identified by J. G. Vedder)

Gastropods

Bittium alternatum (Gabb)

Calyptraea diegoana (Conrad)

Conus remondii $\mathrm{Gabb}$

Cylichnina cf. C. tantilla (Anderson and Hanna)

Ectinochilus (Cowlitzia) cf. E. (C.) supraplicatus

(Gabb)

Ficopsis cf. F. remondii crescentensis Weaver and Palmer Molopophorus antiquatus (Gabb)

Niso polita Gabb

Olivella cf. O. mathewsonii Gabb

?Perse sinuata (Gabb)

Pleurofusia? sp.

Pseudoperissolax blakei (Conrad) 
Locality F113-Continued

Scaphander costatus (Gabb)

Tejonia lajollaensis (Stewart)

Turritella aff. T. buwaldana Dickerson

Pelecypods

Brachidontes sp.

Corbula sp.

Glycymeris cf. G.sagittata (Gabb)?

Pitar? (Calpitaria?) cf. P. (C.) uvasana (Conrad)

Locality F114 (identified by W. P. Woodring, as published in U. S. Geological Survey Preliminary Chart 12 (Woodring and Popenoe, 1945) with nomenclatural alterations by C. R. Givens, 1977)

Gastropods

Calyptraea diegoana (Conrad)

Loxotrema cf. L. turritum Gabb

Pachycrommium cf. P. clarki (Stewart)

Scaphander costatus (Gabb)

Tejonia lajollaensis (Stewart)

Turritella buwaldana Dickerson?

Pelecypods

Acanthocardia (Schedocardia) brewerii (Gabb)

Callista (Costacallista)? cf. C. (C.) hornii (Gabb)

Glycymeris cf. G. sagittata (Gabb)?

Nemocardium linteum (Conrad)

Locality F114 a

Pitar? (Calpitaria) cf. P. (C.) uvasana (Conrad)

Pelecypods

Mytilus cf. M. dichotomus Cooper

Pododesmus (Monia) cf. P. (M.) inornatus (Gabb)

Locality F114b

Gastropods

Calyptraea cf. C. diegoana (Conrad)

Turritella cf. T. meganosensis Clark and Woodford

Pelecypods

Acanthocardia? (Schedocardia?) cf. A. (S.) brewerii (Gabb)

Brachidontes cf. $B$. cowlitzensis (Weaver and Palmer)

Corbula cf. C. parilis Gabb

Nemocardium? sp.

Pitar? (Calpitaria?) cf. P. (C.) campi Vokes

Spisula? sp.

Tellina cf. T. soledadensis M. A. Hanna

\section{EOCENE(?) TO MIOCENE}

\section{SESPE AND VAQUEROS FORMATIONS, UNDIFFERENTIATED}

Fossils identified by J. G. Vedder and W. P. Woodring, 1953, with nomenclatural alterations by Ellen J. Moore, 1977. (For locality descriptions and U. S. Geological Survey locality numbers see megafossil locality list.)

Locality F115

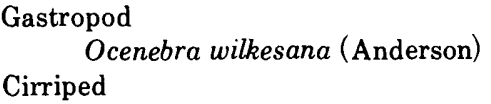

Locality F116

Echinoid

Kewia? cf. K. fairbanksi (Arnold)

Gastropods

Neverita (Glossaulax) reclusiana (Deshayes)?

Olivella (Callianax?) santana Loel and Corey

Pelecypods

"Terebra" santana Loel and Corey

Locality F117

Anadara (Larkinia) santana (Loel and Corey)

Tivela (Pachydesma) inezana (Conrad)

Gastropods

Calyptraea (Trochita) filosa (Gabb)?

Ocenebra topangensis Arnold

Pelecypods

Crenomytilus cf. C. expansus (Arnold)

Zirface cf. $Z$. dentata (Gabb)

Cirriped

Balanus sp.

Locality F118

Echinoid

Vaquerosella cf. V. norrisi (Pack)

Locality F119

Gastropods

Ocenebra topangensis Arnold

Trophon (Austrotrophon) cf. T. (A.) kernensis Anderson

Pelecypods

Crenomytilus cf. C. expansus (Arnold)

Lyropecten magnolia (Conrad)

Cirripeds

Solen sp.?

Balanus sp.

Tamiosoma sp.

Locality F120

Pelecypods

Crassatella cf. C. granti (Wiedey)

Miltha (Miltha) sanctaecrucis (Arnold)

Locality F121

Gastropods

Bittium topangensis (Arnold)?

Conus (Chelyconus) owenianus Anderson

Megasurcula cf. M. keepi (Arnold)

Neverita (Glossaulax) reclusiana (Deshayes)?

Pelecypod

Macoma (Rexithaerus) secta (Conrad)?

Cirriped

Balanus sp.

Locality F122

Gastropods

Calyptraea (Trochita) filosa (Gabb)?

Ocenebra topangensis Arnold

"Terebra" santana Loel and Corey

Turritella (Torcula) inezana santana Loel and Corey

Pelecypods

Anadara (Larkinia) santana (Loel and Corey)?

Corbula sp.

Crenomytilus cf. C. expansus (Arnold)

Dosinia margaritana Wiedey

Saccella sp.?

Saxidomus aff. S. vaquerosensis Arnold)?

Cirriped

Tivela (Páchydesma) inezana (Conrad)

Locality F123

Balanus sp.

Echinoid

Kewia? fairbanksi santanensis (Kew) 
Locality F 124

Gastropods

Olivella (Callianax?) santana Loel and Corey

Potamides sespeensis Loel and Corey?

Rapana cf. $R$. vaquerosensis (Arnold)

Rapana vaquerosensis imperialis Hertlein and Jordan

"Terebra" santana Loel and Corey

Turritella (Torcula) inezana santana Loel and Corey

Pelecypod Cirriped

Anadara (Larkinia) santana (Loel and Corey)

Locality F125

Balanus sp.

Gastropods

Rapana aff. $R$. vaquerosensis imperialis Hertlein and Jordan

Turritella (Torcula) inezana santana Loel and Corey

Pelecypods

Anadara (Larkinia) santana (Loel and Corey)

Locality F126

Clementia (Egesta) pertenius (Loel and Corey)

Echinoid

Kewia? cf. K. ? fairbanksi (Arnold)

Gastropod

"Terebra" cf. "T." santana Loel and Corey Pelecypod

Macoma? sp.

Locality F127

Echinoid

Vaquerosella? vaquerosensis (Kew)?

Gastropod

Calyptraea (Trochita) filosa (Gabb)?

Pelecypod

Tellina (Olcesia) cf.T. (O.) piercei (Arnold)

Locality F128

Gastropod

Locality F 129

Turritella (Torcula) inezana santana Loel and Corey

Echinoid

Kewia? cf. K.? fairbanksi (Arnold)

Gastropod

Pelecypod

'Terebra" cf. "T."' santana Loel and Corey

Locality F130

Macoma? sp.

Pelecypods

Anadara (Larkinia) santana (Loel and Corey)

Clementia (Egesta) cf. C. (E.) pertenuis (Gabb)

Macoma? sp.

Losality F131

Gastropod

Pelecypod

Conus (Chelyconus) owenianus Anderson

Locality F132

Crassatella of. C. granti (Wiedey)

Gastropod

Turritella (Torcula) inezana santana Loel and Corey

Pelecypods

Ostrea sp.

Tellina (Tellinella) idae Dall?

Tivela (Pachydesma) inezana (Conrad)

Locality F133

Gastropods

"Terebra" santana Loel and Corey

Turritella inezana santana Loel and Carey

Pelecypods
Locality F133-Continued

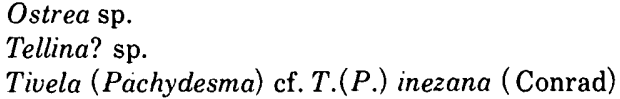

Ostrea sp.

Tellina? sp

Tivela (Pachydesma) cf. T.(P.) inezana (Conrad)

Locality F134

Echinoid

Kewia? fairbanksi santanensis (Kew)

Pelecypods

Crassostrea cf. C. eldridgei (Arnold)

Ostrea sp.

Locality F135

Gastropods

Conus (Chelyconus) owenianus Anderson

Neverita (Glossaulax) reclusiana (Deshayes)?

Olivella (Callianax?) santana Loel and Corey

Rapana cf. $R$. vaquerosensis imperialis Hertlein and Jordan

Pelecypod

Cirriped

Tivela (Páchydesma) inezana (Conrad)

Locality F136

$$
\text { Balanus sp. }
$$

Gastropod

Turritella (Torcula) inezana santana Loel and Corey

Locality F137

Gastropod

Pelecypod

Turritella (Torcula) cf. T. (T.) inezana santana Loel and

$$
\text { Corey }
$$

Ostrea sp.

Locality F138

Gastropods

Rapana cf. $R$. vaquerosensis (Arnold)?

Turritella (Torcula) inezana santana Loel and Corey

Pelecypods

Anadara (Larkinia) cf. A. (L.) santana (Loel and Corey)

Locality F139

Here excavata (Carpenter)?

Gastropod

Rapana vaquerosensis imperialis Hertlein and Jordan

Locality F140

Pelecypod

Locality V

Lyropecten cf. L. miguelensis (Arnold)

Elasmobranchs

?Oxyrhina sp.

Batoid, gen. and sp. indet.

Chelonian

Gen. and sp. indet.

Equid

Miohippus, Parahippus, or Anchitherium

Camelid

Paratylopus cf. $P$. primaevus Matthew

MIOCENE

TOPANGA FORMATION

Fossils identified by J. G. Vedder and W. P. Woodring, 1953, with nomenclatural alterations by Ellen J. Moore, 1977. (For locality descriptions and U. S. Geological Survey locality numbers see megafossil locality list.) 
Locality F141

Pelecypods

Chione (Chionopsis) temblorensis (Anderson)?

Dosinia (Dosinia) whitneyi (Gabb)

Locality F142 Lyropecten crassicardo (Conrad)?

Gastropods

Bittium topangensis (Arnold)

Calyptraea (Trochita) filosa (Gabb)?

Mitrella sp.

Turritella ocoyana Conrad

T. temblorensis Wiedey

Pelecypods

Cryptomya? sp.

Leptopecten andersoni (Arnold)

Locality F143

Gastropod

Bittium tonpangensis (Arnold)?

Pelecypod

Leptopecten andersoni (Arnold)?

Locality F144

Echinoid

Vaquerosella norrisi (Pack)

Pelecypod

Crenomytilus cf. C. expansus (Arnold)?

Locality F145

Gastropods

Calyptraea (Trochita) filosa (Gabb)?

Turritella ocoyana Conrad

Turritella $\mathrm{cf}$. T. ocoyana topangensis Merriam

Turritella temblorensis Wiedey

Pelecypod

Chione (Chionopsis) temblorensis (Anderson)?

Cirriped

Balanus sp.

Locality F146

Echinoid

Locality F147

Vaquerosella norrisi (Pack)

Gastropods

Acmaea? sp.

Calyptraea (Trochita) filosa (Gabb)?

Ficus (Trophosycon) cf. F. (T.) kerniana (Cooper)

Neverita (Glossaulax) reclusiana (Deshayes)?

Ocenebra topangensis Arnold

Trophon (Austrotrophon) cf. T. (A.) kernensis Anderson?

Turritella $\mathrm{cf}$. T. ocoyana topangensis Merriam

Pelecypods

Anadara (Anadara) cf. A. (A.) osmonti (Dall)

Anomia? sp.

Chione (Chionopsis) cf. C. (C.) temblorensis (Anderson)

Hiatella? sp.

Miltha (Miltha) sanctaecrucis (Arnold)?

Panopea cf. P. generosa (Gould)

Tellina (Tellinella) idae Dall?

Vertipecten nevadanus (Conrad)

Locality F148

Pelecypod

Locality F149

Vertipecten nevadanus (Conrad)

Pelecypod

Vertipecten nevadanus (Conrad)

Locality F150

Gastropods
Locality F150-Continued

Neverita (Glossaulax) reclusiana (Deshayes)?

Ocenebra topangensis Arnold

Turritella ocoyana Conrad

Pelecypods

Crassotrea eldridgei ynezana (Loel and Corey)?

Crassotrea cf. C. titan subtitan Loel and Corey

Locality F151

Vertipecten nevadanus (Conrad)

Gastropod

Turritella ocoyana Conrad

Pelecypod

Locality F152

Crassotrea cf. C. titan subtitan Loel and Corey

Echinoid

Locality F153

Vaquerosella norrisi (Pack)

Echinoids

Vaquerosella andersoni (Twitchell)

Spatangoid

Locality F154

Gastropods

Turritella ocoyana Conrad

Turritella ef. T. ocoyana topangensis Merriam

Locality F155

Gastropods

Cancellaria (Euclia) cf. C. (E.) condoni Anderson

Neverita (Glossaulax) reclusiana (Deshayes)?

Oliva (Oliva) californica Anderson

Tritonalia? sp.

Turritella ocoyana Conrad

Turritella $\mathrm{cf}$. T. ocoyana topangensis Merriam

Turritella temblorensis Wiedey

Pelecypod

Corbula sp.

Cirriped

Balanus sp.

Locality F156

Gastropods

Bruclarkia cf. B. barkeriana (Cooper)

Calyptraea (Trochita) filosa (Gabb)?

Trophon (Austrotrophon) cf. T. (A.) kernensis Anderson

Pelecypods

Amiantis cf. A. callosa (Conrad)?

Chione (Chionopsis) temblorensis (Anderson)

Dosinia cf. D. margaritana Wiedey

Spisula cf. S. catilliformis Conrad

Tellina (Olcesia) cf. T. (O.) piercei (Arnold)

Tresus sp.

Locality F157

Pelecypod

Vertipecten nevadanus (Conrad)

Locality F158

Gastropod

Bruclarkia cf. B. barkeriana (Cooper)

Pelecypods

Chione (Chionopsis) cf. C. (C.) temblorensis (Anderson)

Clementia (Egesta) cf. C. (E.) pertenuis (Gabb)

Dosinia cf. D. margaritana Wiedey

Here cf. H. excavata Carpenter

Macrocallista aff. M. squalida (Sowerby)

Panopea cf. P. generosa (Gould)

Locality F159

Spisula sp.?

Gastropod 
Locality F159 - Continued

Nassarius (Catilon?) cf. N. (C.?) antiselli

Pelecypods

(Anderson and Martin)

Anadara (Anadara) cf. A. (A.) osmonti (Dall)

Cyclocardia? sp.

Lucinoma cf. L. annulata (Reeve)?

Saccella sp.

Locality F 160

Gastropod

Locality F161

Turritella ocoyana Conrad

Gastropod

Turritella ocoyana Conrad

Pelecypods

Locality F162

Chione (Chionopsis) temblorensis (Anderson)

Gastropods

"Cancellaria" n. sp.? A

Conus (Chelyconus) owenianus Anderson

Ficus ('Trophosycon) cf. F. (T.) kerniana (Cooper)

Neverita (Glossaulax) reclusiana (Deshayes)?

Turritella ocoyana Conrad

Pelecypods

Chione (Chionopsis) temblorensis (Anderson)?

Dosinia cf. D. margaritana Wiedey

Locality F 163

Gastropods

Amphissa sp.

Antillophos posunculensis (Anderson and Martin)

Bittium topangensis (Arnold)

Bittium topangensis (Arnold), form lacking prominent nodes

Cancellaria (Euclia) cf. C. (E.) cassidiformis Sowerby

Cancellaria (Euclia) cf. C. (E.) condoni (Anderson)

Cancellaria (Pyruclia) C. (P.) lickana Anderson and Martin

"Cancellaria" n. sp. ? A

"Cancellaria" n. sp. ? B

Conus (Chelyconus) owenianus Anderson

Conus (Lithoconus) cf. C. (L.) hayesi Arnold

Conus (Lithoconus) cf. C. (L.) regularis Sowerby

Crucibulm aff. C. spinosum (Sowerby)

Mitrella (Columbellopsis) aff. M. (C.) tuberosa (Carpenter)

Murex (Chicoreus) n. sp.?

Nassarius n. sp.?

Nassarius (Catilon?) cf. N. (C.?) antiselli (Anderson and Martin)

Neverita (Glossaulax) reclusiana (Deshayes)

Neverita (Glossaulax) reclusiana (Deshayes), low spired form

Ocenebra wilkesana (Anderson)

Oliva (Oliva) californica Anderson

Sinium scopulosum (Conrad)

Strombina carlosensis Durham?

Tegula sp.

Terebra (Terebra) cooperi (Anderson)

Thais (Thaisella) cf. T. (T.) edmondi Arnold

Tritonalia $\mathrm{n} . \mathrm{sp}$ ?

Trochita trochiformis (Born)

Turricula cf. T. maculosa (Sowerby)

Turricula cf. T. ochsneri (Anderson and Martin)

Turricula cf. T. wilsoni (Anderson and Martin)

Turricula? sp.
Locality F163-Continued

Turritella ocoyana Conrad

Turritella cf. T. ocoyana topangensis Merriam

Turritella temblorensis Wiedey

Pelecypods

Amiantis cf. A. callosa (Conrad)

Amiantis n. sp.?

Anadara (Anadara) ef. A. (A.) osmonti (Dall)

Anadara (Cunearca) cf. A. (C.) rivulata (Wiedey)

Anodontia (Pegophysema) cf. A. (P.) edentuloides (Verrill)

Chione (Chionopsis) temblorensis (Anderson)

Chlamys cf. C. hertleini (Loel and Corey)

Clementia (Egesta) pertenuis (Gabb)

Corbula (Caryocorbula) cf. C. (C.) luteola Cooper

Crassotrea freudenbergi Hertlein and Jordan?

Crassotrea cf. C. titan subtitan Loel and Corey

Crenomytilus cf. C. expansus Arnold

Eucrassatella n. sp.?

Fellaniella cf. F. harfordi (Anderson)

Glycymeris (Glycymeris) aff. G. (G.) maculata (Broderip)

Glycymeris cf. G. whaleyi Nicol

Here excavata Carpenter

Leptopecten andersoni (Arnold)?

Lucinoma cf. L. annulata (Reeve)

Macrocallista (Megapitaria) aff. M. (M.) squalida (Sowerby)

Miltha (Miltha) sanctaecrucis (Arnold)

Ostrea sp.

Psammotreta obesa (Deshayes)

Saxidomus aff. S. vaquerosensis Arnold

Semele? sp.

Spisula cf. S. catilliformis Conrad?

Tagelus cf. T. clarki Loel and Corey

Tellina (Olcesia) cf. T. (O.) piercei (Arnold)

Tellina (Tellinella) idae Dall

Tivela (Tivela) cf. T. (T.) delesserti Deshayes

Trachycardium (Dallocardia) senticosum (Sowerby)

Cirripeds

Trächycardium cf. T. vaquerosensis (Arnold)

Balanus sp.

Balanus sp, heavy ribbed form

Locality F164

Gastropod

Pelecypod

Turritella ocoyana Conrad

Locality F165

Leptopecten andersoni (Arnold)

Pelecypod

Leptopecten andersoni (Arnold)

Locality F166

Gastropod

Turritella ef. T. ocoyana Conrad

Pelecypods

Leptopecten andersoni (Arnold)

Trachycardium (Acrosterigma) cf. T. (A.) vaquerosensis (Arnold)

Locality F 167

Gastropods

Bruclarkia cf. B. barkeriana (Cooper)?

Calyptraea (Calyptraea) inornata (Gabb)

Neverita (Glossaulax) reclusiana (Deshayes)?

Pelecypods

Chione (Chionopsis) temblorensis (Anderson)

Dosinia margaritana Gabb 
Locality F167-Continued

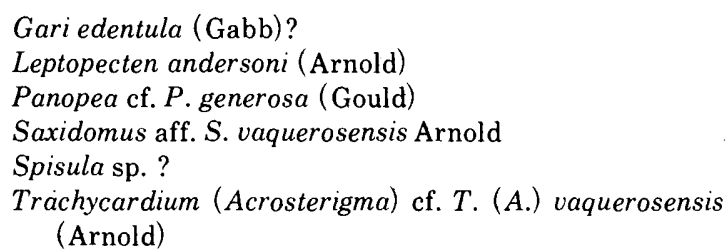

\section{Locality F173-Continued}

Tellina (Olcesia) cf. T. (O.) piercei (Arnold)?

Tellina (Tellinella) idae Dall?

Trachycardium (Dallocardia) cf. T. (D.) quadrigenarium. (Conrad)

Trachycardium (Acrosterigma) cf. T. (A.) vaquerosensis (Arnold)

\section{PLIOCENE \\ FERNANDO MEMBER}

Fossils identified by W. P. Woodring and Ellen J. Moore, 1952, with nomenclature alterations by Ellen J. Moore, 1977. (For locality descriptions and U.S. Geological Survey numbers see megafossil locality list.)

Locality F174

Gastropods

Barbarofusus cf. B. arnoldi (Cossmann)

Crepidula sp.

Megasurcula sp.

Nassarius sp.

Neverita (Glossaulax) reclusiana (Deshayes)?

Pelecypods

Acila (Truncacila) castrensis (Hinds)

Anadara (Anadara) trilineata (Conrad)?

Chione? sp.

Lucinoma cf. L. annulata (Reeve)

Saccella taphria (Dall)

Locality F175

Tellina? sp.

Gastropods

Astraea (Megastrea) cf. A. (M.) gradata (Grant and Gale), operculum

Neverita (Glossaulax) reclusiana (Deshayes)?

Pelecypods

Amiantis callosa (Conrad)?

Diplodonta cf. D. subquadrata Carpenter

Cirriped Miltha? sp.

Locality F176

Balanus? sp.

Gastropods

Crepidula? sp.

Turritella gonostoma hemphilli Merriam?

Pelecypods

Anadara (Anadara) trilineata calcarea (Grant and Gale) Cyclocardia sp.

Macoma? sp.

Locality F177

Thyasira cf. T. gouldii (Philippi)

Gastropods

Astraea (Megastrea) cf. A. (M.) gradata (Grant and Gale); operculum

Neverita (Glossaulax) reclusiana (Deshayes)?

Pelecypod

Turritella gonostoma hemphilli Merriam

Locality F178

Anadara (Larkinia) camuloensis (Osmont)

Gastropods

Neverita (Glossaulax) reclusiana (Deshayes)?

Turritella gonostoma hemphilli Merriam?

Pelecypod

Anadara (Anadara) trilineata calcarea (Grant and Gale) 


\section{LIST OF MICROFOSSILS \\ MIOCENE \\ TOPANGA FORMATION}

Fossils identified by Patsy B. Smith, 1958, and published in 1960. ( $R$, rare; F, few; C, common; A, abundant.) (For locality descriptions and U. S. Geological Survey locality numbers see microfossil locality list.) Locality $\mathrm{m} 179$

Bolivina advena Cushman, undescribed variant Buliminella curta Cushman

Buliminella subfusiformis Cushman

Nonion costiferum (Cushman)

Nonion aff. N. costiferum (Cushman)

Locality $\mathrm{m} 180$

Bolivina advena Cushman var.

Nonion aff. N. costiferum (Cushman)

Locality $\mathrm{m} 181$

Bolivina advena Cushman, undescribed variant

Buliminella subfusiformis Cushman

Epistominella? sp.

Nonion aff. N. costiferum (Cushman)

Locality $\mathrm{m} 182$

Bolivina tumida Cushman var.

Bolivina cf. $B$. decurtata Cushman

Bolivina ef. B. subadvena Cushman

Buliminella curta Cushman

Buliminella subfusiformis Cushman

Nonion aff. N. costiferum (Cushman)

Suggrunda kleinpelli Bramlette

Valvulineria depressa Cushman

Locality $\mathrm{m} 183$ EL MODENO VOLCANICS

Bolivina decurtata Cushman

Bolivina sinuata alisoensis Cushman and Adams

Bolivina tumida Cushman

Bulimina montereyana Kleinpell

Buliminella subfusiformis Cushman

Epistominella gyroidinaformis (Cushman and

Goudkoff)

Epistominella relizensis (Cushman and Kleinpell)

Nonion pizarrensis $\mathrm{W}$. Berry

Valvulineria californica obesa Cushman

Locality $\mathrm{m} 184$

MONTEREY SHALE

Bolivina advena striatella Cushman

Bolivina decurtata Cushman

Bolivina interjuncta bicostata Cushman

Bolivina marginata gracillima Cushman

Bolivina obliqua Barbat and Johnson

Bolivina tumida Cushman

Bolivina cf. B. woodringi Kleinpell

Buliminella curta Cushman

Buliminella subfusiformis Cushman

Cassidulina limbata Cushman and Hughes

Cassidulina cf. C. margareta Karrer

Cibicides sp.

Epistominella relizensis (Cushman and Kleinpell)

Globigerina bulloides d'Orbigny

Gyroidina rotundimargo R. E. and K. C. Stewart

Nonion costiferum (Cushman)

Planulina ornata d'Orbigny

Suggrunda kleinpelli Bramlette

Uvigerina subperegrina Cushman and Kleinpell

"Uvigerinella" californica Cushman, undescribed variant
Locality m184-Continued

Valvulineria californica obesa Cushman

Valuulineria cf. $V$. grandis Cushman and Galliher

Valvulineria williami Kleinpell

Virgulina californiensis Cushman

Locality $\mathrm{m} 185$

Baggina californica Cushman

Bolivina decurtata Cushman

Bolivina cf. B. barbarana Cushman and Kleinpell

Bolivina cf. B. woodringi Kleinpell

Boliminella curta Cushman

Buliminella subfusiformis Cushman

Epistominella relizensis (Cushman and Kleinpell)

Globigerina bulloides d'Orbigny

Planulina ornata d'Orbigny

Suggrunda kleinpelli Bramlette

Uvigerina subperegrina Cushman and Kleinpell

\section{PUENTE FORMATION}

LA VIDA MEMBER

Locality $\mathrm{m} 186$

Bolivina decurtata Cushman

Bolivina rankini Kleinpell

Bolivina sinuata alisoensis Cushman and Adams

Bolivina tumida Cushman

Buliminella curta Cushman

Cibicides illingi (Nuttall)

Epistominella pacifica (R.E. and K. C. Stewart)

Uvigerina subperegrina Cushman and Kleinpell

"Uvigerinella" californica Cushman, undescribed variant

Locality $\mathrm{m} 187$

Baggina californica Cushman

Bolivina decurtata Cushman

Bolivina sinuata alisoensis Cushman and Adams

Buliminella ecuadorana Cushman and Stevenson

Epistominella gyroidinaformis (Cushman and Goudkoff)

"Uvigerinella" californica Cushman

Locality $\mathrm{m} 188$

Bolivina barbarana Cushman and Kleinpell

Bolivina cf. $B$. decurtata Cushman

Bolivina sinuata alisoensis Cushman and Adams

Bolivina tumida Cushman

Buliminella ecuadorana Cushman and Stevenson

Epistominella subperuviana (Cushman)

Valvulineria cf. V. grandis Cushman and Galliher

Valuulineria cf. $V$. williami Kleinpell

Locality m 189

Bolivina decurtata Cushman

Bolivina sinuata alisoensis Cushman and Adams

Buliminella curta Cushman

Uvigerina joaquinensis Kleinpell

Valvulineria cf. V. grandis Cushman and Galliher

Locality m190

Buliminella ecuadorana Cushman and Stevenson A

Epistominella relizensis (Cushman and Kleinpell)

Epistominella subperuviana (Cushman)

"Uvigerinella" californica Cushman, undescribed variant

Locality $\mathrm{m} 191$

Bolivina sinuata alisoensis Cushman and Adams $\quad \mathrm{R}$

Bolivina tumida Cushman

Bolivina cf. B. marginata gracillima Cushman
$\mathrm{R}$
$\mathrm{R}$
$\mathrm{R}$
$\mathrm{R}$
$\mathrm{R}$
$\mathrm{A}$
$\mathrm{R}$
$\mathrm{R}$
$\mathrm{R}$
$\mathrm{R}$
$\mathrm{F}$
$\mathrm{R}$
$\mathrm{R}$
$\mathrm{R}$
$\mathrm{R}$ 
Locality m191-Continued

Bolivina cf. B. vaughani Natland

Buliminella ecuadorana Cushman and Stevenson

Epistominella relizensis (Cushman and Kleinpell)

Globigerina bulloides d'Orbigny

Uvigerina joaquinensis Kleinpell

Uvigerina subperegrina Cushman and Kleinpell

Locality $\mathrm{m} 192$

Angulogerina? sp.

Bolivina decurtata Cushman

Bolivina interjuncta bicostata Cushman

Bolivina sinuata alisoensis Cushman and Adams

Bolivina tumida Cushman

Bolivina ef. B. vaughani Natland

Buliminella curta Cushman

Bulimina uvigerinaformis Cushman and Kleinpell

Cibicides illingi (Nuttall)

Epistominella subperuviana (Cushman)

Globigerina bulloides d'Orbigny

Robulus smileyi Kleinpell

Uvigerina subperegrina Cushman and Kleinpell

Valvulineria cf. V. grandis Cushman and Galliher

Locality $\mathrm{m} 193$

Bolivina cf. B. interjuncta bicostata Cushman

Bolivina pseudospissa Kleinpell

Bolivina ef. B. vaughani Natland

Globigerina bulloides d'Orbigny

Robulus smileyi Kleinpell

Uvigerina subperegrina Cushman and Kleinpell

Valvulineria cf. V. grandis Cushman and Galliher

Locality m194

Bolivina decurtata Cushman

Buliminella curta Cushman

Epistominella relizensis (Cushman and Kleinpell)

Globigerina bulloides d'Orbigny

Suggrunda kleinpelli Bramlette

Valvulineria cf. V. grandis Cushman and Galliher

Locality m195

Bolivina decurtata Cushman

Bolivina marginata gracillima Cushman

Bolivina sinuata alisoensis Cushman and Adams

Bolivina cf. B. vaughani Natland

Buliminella ecuadorana Cushman and Stevenson

Epistominella relizensis (Cushman and Kleinpell)

Gyroidina sp.

Valvulineria cf. V. grandis Cushman and Galliher

Locality $\mathrm{m} 196$

Bolivina decurtata Cushman

Bolivina marginata gracillima Cushman

Bolivina cf. B. salinasensis Kleinpell

Bolivina cf. B. subhughesi Kleinpell

Bolivina cf. B. vaughani Natland

Bulimina delreyensis Cushman and Galliher

Bulimina cf. B. pseudoaffinis Kleinpell

Bulimina uvigerinaformis Cushman and Kleinpell

Buliminella subfusiformis Cushman

Epistominella relizensis (Cushman and Kleinpell)

Eponides rosaformis Cushman and Kleinpell

Globigerina bulloides d'Orbigny

Uvigerina cf. U. subperegrina Cushman and Kleinpell $\mathrm{R}$

Virgulina californiensis Cushman

Locality $\mathrm{m} 197$

Bolivina californica Cushman

Bolivina girardensis Rankin
Locality m197-Continued

Bolivina modeloensis Cushman and Kleinpell

Bolivina obliqua Barbat and Johnson

Bolivina sinuata alisoensis Cushman and Adams

Bolivina cf. B. subhughesi Kleinpell

Bolivina ef. B. vaughani Natland

Bulimina delreyensis Cushman and Galliher

Bulimina cf. B. pseudoaffinis Kleinpell

Buliminella subfusiformis Cushman

Epistominella relizensis (Cushman and Kleinpell)

Eponides rosaformis Cushman and Kleinpell

Planulina ornata d'Orbigny

Valvulineria cf. V. grandis Cushman and Galliher

Locality $\mathrm{m} 197 \mathrm{a}$

Bolivina girardensis Rankin

Bolivina cf. B. pseudospissa Kleinpell

Bolivina cf. B. vaughani Natland

Bolivina woodringi Kleinpell

Buliminella curta Cushman

Buliminella subfusiformis Cushman

Epistominella relizensis (Cushman and Kleinpell)

Gyroidina sp.

Nonion cf. N. pizarrensis W. Berry

Uvigerina joaquinensis Kleinpell

Locality m199

Bolivina cf. B. decurtata Cushman

Bolivina woodringi Kleinpell

Bulimina delreyensis Cushman and Galliher

Epistominella relizensis (Cushman and Kleinpell)

Globigerina bulloides d'Orbigny

Gyroidina sp.

Nonionella miocenica (Cushman)

Uvigerina joaquinensis Kleinpell

Valvulineria cf. $V$. grandis Cushman and Galliher

Locality m200

\section{I.A VIDA AND YORBA MEMBERS} UNDIFFERENTIATED

Bolivina californica Cushman

Bolivina decurtata Cushman

Bolivina marginata gracillima Cushman

Bolivina sinuata alisoensis Cushman and Adams

Bolivina cf. B. vaughani Natland

Bulimina uvigerinaformis Cushman and Kleinpell

Epistominella relizensis (Cushman and Kleinpell) Globigerina bulloides d'Orbigny

Suggrunda kleinpelli Bramlette

Uvigerina subperegrina Cushman and Kleinpell

R

Locality $\mathrm{m} 201$

Bolivina marginata gracillima Cushman

Bolivina sinuata alisoensis Cushman and Adams

Bolivina cf. B. subhughesi Kleinpell

Bolivina cf. $B$. vaughani Natland

Buliminella cf. B. pseudoaffinis Kleinpell

Bulimina uvigerinaformis Cushman and Kleinpell

Buliminella curta Cushman

Buliminella subfusiformis Cushman

Epistominella relizensis (Cushman and Kleinpell)

Eponides rosaformis Cushman and Kleinpell

Globigerina bulloides d'Orbigny

Valuulineria cf. $V$. grandis Cushman and Galliher Locality m202

Bolivina decurtata Cushman
$\mathbf{R}$
$\mathbf{R}$
$\mathbf{R}$
$\mathrm{R}$
$\mathrm{R}$
$\mathrm{R}$
$\mathrm{R}$
$\mathrm{A}$
$\mathrm{R}$
$\mathrm{R}$

$\mathrm{R}$

$\mathrm{R}$

C

R.

$\mathrm{R}$

$\mathbf{R}$

R

$\mathrm{R}$

$\mathrm{R}$

$\mathrm{C}$ 
Locality m202-Continued

Bolivina cf. B. vaughani Natland

Bolivina woodringi Kleinpell

Epistominella relizensis (Cushman and Kleinpell)

Globigerina bulloides d'Orbigny

Hopkinsina magnifica Bramlette

Locality $\mathrm{m} 204$

Bolivina decurtata Cushman

Bolivina girardensis Rankin

Bolivina of. B. vaughani Natland

Bolivina cf. B. woodringi Kleinpell

Buliminella curta Cushman

Buliminella subfusiformis Cushman

Epistominella relizensis (Cushman and Kleinpell)

Gyroidina rotundimargo R. E. and K. C. Stewart

Uvigerina subperegrina Cushman and Kleinpell

I.A VIDA AND YORBA MEMBERS, UNDIFFERENTIATED

Locality m205

Bolivina obliqua Barbat and Johnson

Bolivina tumida Cushman

Bolivina cf. B. vaughani Natland

Buliminella subfusiformis Cushman

Epistominella relizensis (Cushman and Kleinpell)

Globigerina bulloides d'Orbigny

PLIOCENE

\section{FERNANDO FORMATION}

Locality m206

Bolivina pisciformis Galloway and Wissler

Bolivina pocheensis White

Bolivina pygmaea $\mathrm{H}$. B. Brady

Bulimina cf. B. affinis d'Orbigny

Bulimina subacuminata Cushman, R. E. and

K. C. Stewart

Buliminella elegantissima d'Orbigny

Cassidulina spiralis Natland

Cassidulina subglobosa H. B. Brady

Cassidulina translucens Cushman and Hughes

Cibicides mckannai Galloway and Wissler

Epistominella pacifica (R.E. and K. C. Stewart)

Epistominella subperuviana (Cushman)

Gyroidina rotundimargo R. E. and K. C. Stewart

Marginulinopsis capistranoensis White

Uvigerina peregrina Cushman

Virgulina nodosa R. E. and K. C. Stewart

Locality $\mathrm{m} 207$

Bolivina pisciformis Galloway and Wissler

Bolivina pócheensis White

Cassidulina cushmani (R. E. and K. E. Stewart)

Epistominella subperuviana (Cushman)

Globigerina bulloides d'Orbigny

Globobulimina pacifica Cushman

Hanzawaia cf. H. concentrica (Cushman)

Pullenia quinqueloba (Reuss)

Robulus cf. R. americanus Cushman

Uvigerina peregrina Cushman

Locality $\mathrm{m} 208$

Angulogerina carinata Cushman

Bolivina pisciformis Galloway and Wissler

Bulimina subacuminata Cushman, R. E. and

K. C. Stewart

Locality m208-Continued

Cassidulina cushmani R. E. and K. C. Stewart

Cassidulina subglobosa H. B. Brady

Cassidulina translucens Cushman and Huges

Cheilostomella ovoidea Reuss

Cibicides mckannai Galloway and Wissler

Entosolenia sp.

Epistominella pacifica (R.E. and K. C. Stewart)

Epistominella subperuviana (Cushman)

Glandulina laevigata d'Orbigny

Globigerina bulloides d'Orbigny

Globobulimina pacifica Cushman

Nonionella translucens (Cushman)

Orbulina universa d'Orbigny

Pullenia quinqueloba (Reuss)

Robulus cf. R. americanus Cushman

Stilostomella lepidula (Schwager)

Uvigerina peregrina Cushman

Valvulineria araucana d'Orbigny

Virgulina cornuta Cushman

MEGAFOSSIL LOCALITIES

LATE CRETACEOUS

LADD FORMATION

BAKER CANYON CONGLOMERATE MEMBER

No. usedPermanent Field No. Collected by- Description of locality

in this U.S. Geo-

report $\operatorname{logical}_{\text {Survey No. }}$

F1 25034

C. H. Gray and

In Mabey Canyon, $2,730 \mathrm{~m}$ $8.950 \mathrm{ft})$ south and $215 \mathrm{~m}$
$700 \mathrm{ft})$ east of the northeast corner of the Black Star Canyon quadrangle. Not plotted, east of area shown on geological map, plate 1 .

$\mathrm{R}$

$\mathrm{R}$

R

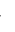

(1)

(1)

R

$\mathrm{R}$

A

$\mathrm{R}$

$\mathrm{R}$

F

$\mathrm{R}$

$\mathrm{R}$

$\mathrm{R}$

$\mathrm{R}$

A

$\mathrm{R}$

$\mathrm{R}$

F6 $25039 \quad \ldots$

R

F1c
Bluffs at base of sandstone, 0.8 $\mathrm{km}(0.5 \mathrm{mi})$ north of Silverado Canyon, west side of Ladd Can. yon. Lowermost fossiliferous beds exposed. (Calif. Inst. Tech. loc. 1292 .)

$\begin{array}{lllll}\text { F1b } & \ldots & \ldots & \text { B. N. Moore.............. L } \begin{array}{c}\text { Limy sandstone bed near base of } \\ \text { shale. South of roadcut at }\end{array}\end{array}$ Holz's Ranch. This locality may become obscured by slides. Sil. verado Canyon. (Calif. Inst.

In sandstone above conglomerate. at fork of Ladd and Silverado Canyon. (Calif. Inst. Tech. loc.

Near head of Mabey Canyon. $4,245 \mathrm{~m}(13.925 \mathrm{ft})$ south and $1.310 \mathrm{~m}(4.300 \mathrm{ft})$ west of the northeast corner of the Black tion $768 \mathrm{~m}(2520 \mathrm{ft})$. eleva-

F3 $25036 \quad$ S85 do............. Near head of Coal Canyon, 2,775 $\mathrm{m}(9.100 \mathrm{ft})$ south and $3.580 \mathrm{~m}$ east corner of the Black Star Canyon quadrangle, elevation $755 \mathrm{~m}(2,480 \mathrm{ft})$.

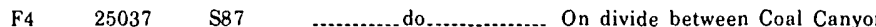
and Fremont Canyon $3230 \mathrm{~m}$ and Fremont Canyon, $3,230 \mathrm{~m}$ $\{12.050 \mathrm{ft}\}$ west of the north. east corner of the Black Star Canyon quadrangle. elevation $750 \mathrm{~m}(2,460 \mathrm{ft})$.

$\begin{array}{llll}\text { F5 } & 25038 & \ldots & \text { J. G. Vedder ............. In Black Star Canyon, } 8.915 \mathrm{~m}\end{array}$ $\{29.250 \mathrm{ft}$ ) south and $1.950 \mathrm{~m}$ $(6.400 \mathrm{ft})$ west of the northeast corner of the Black Star Canyon guadrangle, elevation $640 \mathrm{~m}$

In Black Star Canyon. $8.475 \mathrm{~m}$ $(27.800 \mathrm{ft})$ south and $1.880 \mathrm{~m}$ corner of the Black Star $\mathrm{Cany}$ corner of the Black Star Canyon $(2,300 \mathrm{ft})$. 


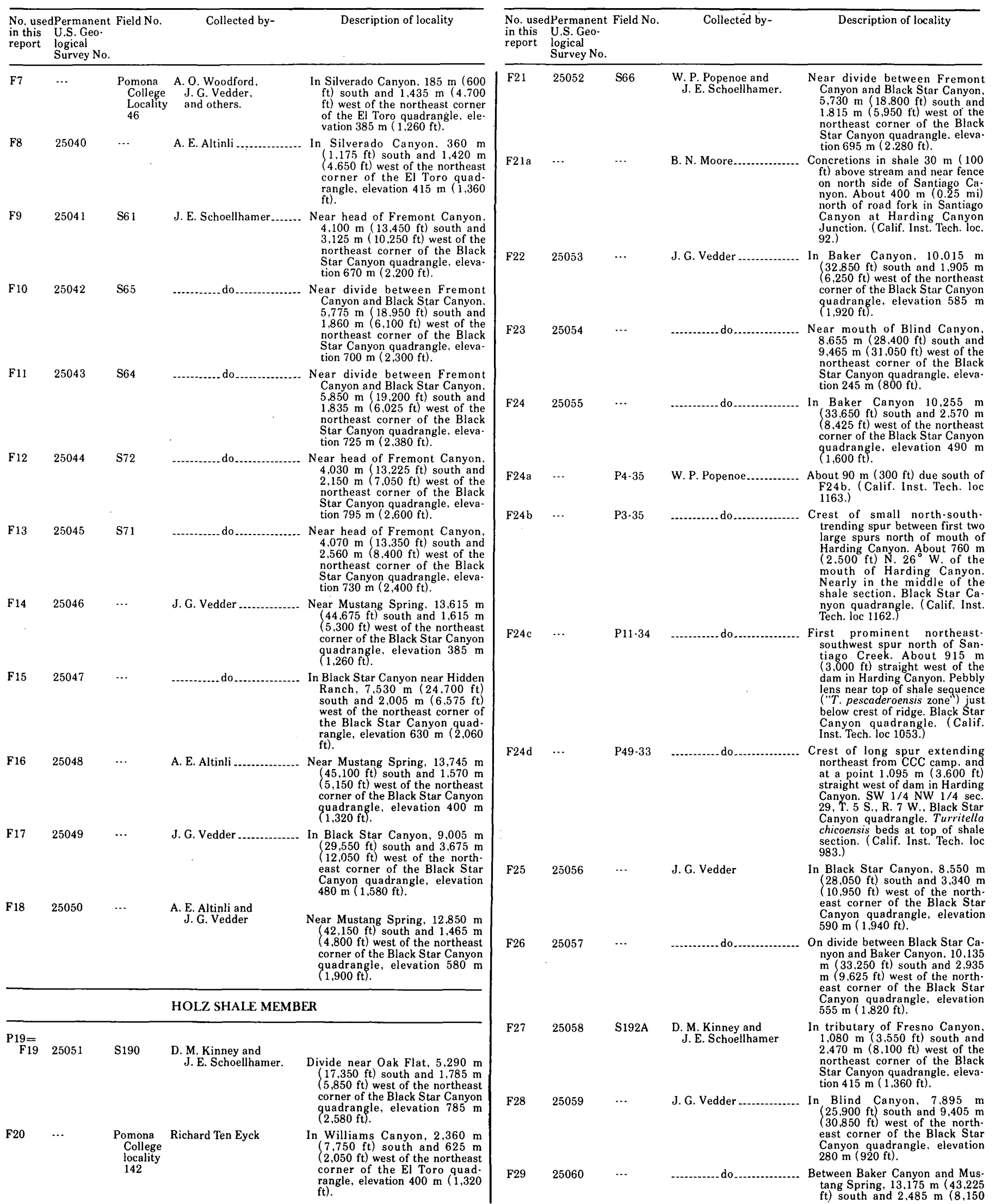









\begin{tabular}{|c|c|c|c|c|c|c|c|c|c|}
\hline $\begin{array}{l}\text { No. usec } \\
\text { in this } \\
\text { report }\end{array}$ & $\begin{array}{l}\text { dPermanent } \\
\text { U.S. Geo- } \\
\text { logical } \\
\text { Survey No. }\end{array}$ & & Collected by- & Description of locality & $\begin{array}{l}\text { No. used } \\
\text { in this } \\
\text { report }\end{array}$ & $\begin{array}{l}\text { dPermanent } \\
\text { U.S. Geo- } \\
\text { logical } \\
\text { Survey No. }\end{array}$ & Field No. & Collected by- & Description of locality \\
\hline F52 & 25082 & $\cdots$ & .............................. & $\begin{array}{l}\text { In Fremont Canyon, } 9,300 \mathrm{~m} \\
(30,175 \mathrm{ft}) \text { south and } 6,690 \mathrm{~m} \\
26,350 \mathrm{ft}) \text { west of the north- } \\
\text { east corner of the Black Star } \\
\text { Canyon quadrangle, elevation } \\
235 \mathrm{~m}(770 \mathrm{ft}) \text {. }\end{array}$ & F66 & 25096 & $\cdots$ & ........................... & $\begin{array}{l}\text { Between Fremont Canyon and } \\
\text { Black Star Canyon, } 9,625 \mathrm{~m} \\
(31.575 \mathrm{ft}) \text { south and } 5,760 \mathrm{~m} \\
(18,900 \mathrm{ft}) \text { west of the north- } \\
\text { east corner of the Black Star } \\
\text { Canyon quadrangle. elevation } \\
520 \mathrm{~m}(1.700 \mathrm{ft}) \text {. }\end{array}$ \\
\hline F53 & 25038 & $\cdots$ & $\begin{array}{l}\text { J. G. Vedder } \\
\text { J.E. Schoellhamer. }\end{array}$ & $\begin{array}{l}\text { On divide between Fremont Can. } \\
\text { yon and Black Star Canyon, } \\
8,800 \mathrm{~m}(28,875 \mathrm{ft}) \text { south and } \\
4,800 \mathrm{~m}(15,750 \mathrm{ft}) \text { west of the } \\
\text { northeast corner of the Black } \\
\text { Star Canyon quadrangle, eleva. } \\
\text { tion } 650 \mathrm{~m}(2,130 \mathrm{ft}) \text {. }\end{array}$ & F67 & 25097 & $\cdots$ & . do & $\begin{array}{l}520 \mathrm{~m}(1,700 \mathrm{ft}) \text {. } \\
\text { Between Blind Canyon and Fre. } \\
\text { mont Canyon, } 8,695 \mathrm{~m}(28,525 \\
\mathrm{ft}) \text { south and } 8,335 \mathrm{~m}(27,350 \\
\mathrm{ft} \text { west of the northeast corner } \\
\text { of the Black Star Canyon quad. } \\
\text { rangle. elevation } 315 \mathrm{~m}(1,030\end{array}$ \\
\hline F54 & 25084 & $\cdots$ & J. G. Vedder & $\begin{array}{l}\text { Between Baker Canyon and Mus. } \\
\text { tang Spring, } 13,345 \mathrm{~m}(43,775 \\
\mathrm{ft} \text { ) south and } 2,790 \mathrm{~m}(9,150 \\
\mathrm{ft} \text { west of the northeast corner } \\
\text { of the Black Star Canyon quad. } \\
\text { rangle, elevation } 435 \mathrm{~m}(1,420 \\
\mathrm{ft}) \text {. }\end{array}$ & F68 & 25098 & $\cdots$ & ................................ & $\begin{array}{l}\mathrm{ft}) \text {. } \\
\text { Between Blind Canyon and Fre. } \\
\text { mont Canyon, } 8,595 \mathrm{~m}(28,200 \\
\mathrm{ft}) \text { south and } 8,190 \mathrm{~m}(26,875 \\
\mathrm{ft}) \text { west of the northeast corner } \\
\text { of the Black Star Canyon quad. } \\
\text { rangle, elevation } 335 \mathrm{~m}(1,100 \\
\mathrm{ft})\end{array}$ \\
\hline F55 & 25085 & $\cdots$ & ........................... & $\begin{array}{l}\text { Near mouth of Black Star Can- } \\
\text { yon, } 10,425 \mathrm{~m}(34,200 \mathrm{ft}) \\
\text { south and } 4,710 \mathrm{~m}(15,450 \mathrm{ft}) \\
\text { west of the northeast corner of } \\
\text { the Black Star Canyon quad. } \\
\text { rangle, elevation } 390 \mathrm{~m}(1,280 \\
\mathrm{ft}) \text {. } \\
\text { Between lrvine Park and Irvine }\end{array}$ & F69 & 25099 & $\cdots$ & -............................... & $\begin{array}{l}\text { ft). } \\
\text { On divide between Blind Canyon } \\
\text { and Fremont Canyon, } 7,735 \mathrm{~m} \\
(25,375 \mathrm{ft}) \text { south and } 8,090 \mathrm{~m} \\
(26,550 \mathrm{ft}) \text { west of the north. } \\
\text { east corner of the Black Star } \\
\text { Canyon quadrangle, elevation } \\
425 \mathrm{~m}(1,400 \mathrm{ft}) \text {. }\end{array}$ \\
\hline F56 & 25086 & $\cdots$ & 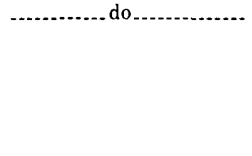 & $\begin{array}{l}\text { Between Irvine Park and Irvine } \\
\text { Lake, 9,355 m }(30,700 \mathrm{ft}) \\
\text { south and } 10,015 \mathrm{~m}(32,850 \mathrm{ft}) \\
\text { west of the northeast corner of } \\
\text { the Black Star Canyon quad. } \\
\text { rangle, elevation } 295 \mathrm{~m}(960 \\
\text { ft). }\end{array}$ & F70 & 25100 & $\cdots$ & . & $\begin{array}{l}\text { Between Irvine Park and Blind } \\
\text { Canyon, } 8,315 \mathrm{~m}(27,275 \mathrm{ft}) \\
\text { south and } 10,805 \mathrm{~m}(35,450 \mathrm{ft}) \\
\text { west of the northeast corner of } \\
\text { the Black Star Canyon quad. } \\
\text { rangle, elevation } 225 \mathrm{~m}(730\end{array}$ \\
\hline F57 & 25087 & $\cdots$ & 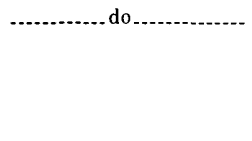 & $\begin{array}{l}\text { In Fremont Canyon, } 9,335 \mathrm{~m} \\
(30,625 \mathrm{ft}) \text { south and } 7,770 \mathrm{~m} \\
25,500 \mathrm{ft}) \text { west of the north- } \\
\text { east corner of the Black Star } \\
\text { Canyon quadrangle, elevation } \\
285 \mathrm{~m}(940 \mathrm{ft}) \text {. }\end{array}$ & F71 & 25101 & $\cdots$ & $\begin{array}{l}\text { D. M. Kinney } \\
\text { J. E. Schoellhamer } \\
\text { and J. G. Vedder }\end{array}$ & $\begin{array}{l}\text { ft). } \\
\text { Between Black Star Canyon and } \\
\text { Baker Canyon, } 10.815 \mathrm{~m} \\
(35,475 \mathrm{ft}) \text { south and } 3,795 \mathrm{~m} \\
12,450 \mathrm{ft}) \text { west of the north. } \\
\text { east corner of the Black Star }\end{array}$ \\
\hline F58 & 25088 & $\cdots$ & ............................. & $\begin{array}{l}\text { Between Blind Canyon and Fre- } \\
\text { mont Canyon, } 8.580 \mathrm{~m}(28,150\end{array}$ & & & & & $\begin{array}{l}\text { Canyon quadrangle, elevation } \\
435 \mathrm{~m}(1,420 \mathrm{ft}) \text {. }\end{array}$ \\
\hline & & & & $\begin{array}{l}\mathrm{ft}) \text { south and } 8,470 \mathrm{~m}(27,800 \\
\mathrm{ft}) \text { west of the northeast corner } \\
\text { of the Black Star Canyon quad. } \\
\text { rangle, elevation } 325 \mathrm{~m}(1,060 \\
\mathrm{ft}) \text {. }\end{array}$ & F71a & $\cdots$ & $\cdots$ & B. N. Moore & $\begin{array}{l}\text { Thin limy sandstone bed on } \\
\text { Santiago-Aliso divide } 805 \mathrm{~m} \\
\text { (0.5 mi) east of county road. } \\
\text { Calif. Inst. Tech. loc. } 86 . \text {.) }\end{array}$ \\
\hline F59 & 25089 & $\cdots$ & .............................. & $\begin{array}{l}\text { Between Williams Canyon and } \\
\text { Santiago Creek, 2,515 m } \\
(8,250 \mathrm{ft}) \text { south and } 1,730 \mathrm{~m} \\
(5.675 \mathrm{ft}) \text { west of the northeast } \\
\text { corner of the El Toro quad. } \\
\text { rangle. elevation } 455 \mathrm{~m}(1.500 \\
\mathrm{ft}) \text {. }\end{array}$ & F71b & $\cdots$ & $\mathrm{P} 15 \cdot 33$ & $\begin{array}{l}\text { W. P. Popenoe } \\
\text { G. H. Anderson }\end{array}$ & $\begin{array}{l}\text { Crest of first east-west spur south } \\
\text { of Williams Canyon, in the NW } \\
1 / 4 \mathrm{NE} 1 / 4 \text { sec. } 19, \mathrm{~T} \text {. } 5 \mathrm{~S} \text {.. R. } \\
7 \text { W., Black Star Canyon quad. } \\
\text { rangle. Limestone beds in } \\
\text { upper sandstone sequence. } \\
\text { (Calif. Inst. Tech. loc. } 976 . \text { ) }\end{array}$ \\
\hline F60 & 25090 & S53 & J.E. Schoellhamer....... & $\begin{array}{l}\text { Near divide between Gypsum } \\
\text { Canyon and Fremont Canyon, } \\
4,770 \mathrm{~m}(15,650 \mathrm{ft}) \text { south and } \\
6,370 \mathrm{~m}(20,900 \mathrm{ft}) \text { west of the } \\
\text { northeast corner of the Black } \\
\text { Star Canyon quadrangle, eleva- } \\
\text { tion } 505 \mathrm{~m}(1,660 \mathrm{ft}) \text {. }\end{array}$ & F72 & 25102 & $\cdots$ & J. G. Vedder & $\begin{array}{l}\text { Between Fremont Canyon and Ir. } \\
\text { vine Lake, } 9,730 \mathrm{~m}(31,925 \mathrm{ft}) \\
\text { south and } 7,680 \mathrm{~m}(25,200 \mathrm{ft}) \\
\text { west of the northeast corner of } \\
\text { the Black Star Canyon quad- } \\
\text { rangle, elevation } 365 \mathrm{~m}(1,200 \\
\mathrm{ft}) \text {. }\end{array}$ \\
\hline F61 & 25091 & $\cdots$ & J. G. Vedder ................ & $\begin{array}{l}\text { Between Weir Canyon and Blind } \\
\text { Canyon, } 6,645 \mathrm{~m}(21,800 \mathrm{ft}) \\
\text { south and } 10,180 \mathrm{~m}(33,400 \mathrm{ft}) \\
\text { west of the northeast corner of } \\
\text { the Black Star Canyon quad. } \\
\text { rangle, elevation } 315 \mathrm{~m}(1,030 \\
\mathrm{ft}) \text {. }\end{array}$ & F73 & 25103 & $\cdots$ & & $\begin{array}{l}\text { Between Silverado Canyon and } \\
\text { Williams Canyon, } 1,770 \mathrm{~m} \\
(5,800 \mathrm{ft}) \text { south and } 1,830 \mathrm{~m} \\
6,000 \mathrm{ft}) \text { west of the northeast } \\
\text { corner of the Black Star Canyon } \\
\text { quadrangle, elevation } 420 \mathrm{~m} \\
(1,370 \mathrm{ft}) \text {. }\end{array}$ \\
\hline F62 & 25092 & $\cdots$ & $\begin{array}{l}\text { J. G. Vedder } \\
\text { J. E. Schoellhamer }\end{array}$ & $\begin{array}{l}\text { Between Fremont Canyon and } \\
\text { Black Star Canyon, } 10,050 \mathrm{~m} \\
(32,975 \mathrm{ft}) \text { south and } 5,015 \mathrm{~m} \\
16,450 \mathrm{ft}) \text { west of the north- } \\
\text { east corner of the Black Star } \\
\text { Canyon quadrangle, elevation } \\
450 \mathrm{~m}(1,470 \mathrm{ft}) \text {. }\end{array}$ & F74 & 25104 & $\cdots$ & ........ do & $\begin{array}{l}\text { Near divide between Gypsum } \\
\text { Canyon and Fremont Canyon, } \\
5,195 \mathrm{~m}(17,050 \mathrm{ft}) \text { south and } \\
6,095 \mathrm{~m}(20,000 \mathrm{ft}) \text { west of the } \\
\text { northeast corner of the El Toro } \\
\text { quadrangle, elevation } 510 \mathrm{~m} \\
(1,680 \mathrm{ft}) \text {. }\end{array}$ \\
\hline F63 & 25093 & $\cdots$ & J. G. Vedder & $\begin{array}{l}\text { Between Black Star Canyon and } \\
\text { Baker Canyon, } 1,180 \mathrm{~m} \\
(38,750 \mathrm{ft}) \text { south and } 3,680 \mathrm{~m} \\
12,075 \mathrm{ft}) \text { west of the north. } \\
\text { east corner of the Black Star }\end{array}$ & F75 & 25105 & $\cdots$ & do & $\begin{array}{l}\text { In Fremont Canyon, } 6,735 \mathrm{~m} \\
(22,100 \mathrm{ft}) \text { south and } 6,525 \mathrm{~m} \\
(21,400 \mathrm{ft}) \text { west of the north- } \\
\text { east corner of the Black Star } \\
\text { Canyon quadrangle, elevation } \\
415 \mathrm{~m}(1,360 \mathrm{ft}) \text {. }\end{array}$ \\
\hline & & & & $\begin{array}{l}\text { Canyon quadrangle, elevation } \\
330 \mathrm{~m}(1,080 \mathrm{ft}) \text {. }\end{array}$ & F76 & 25106 & $\cdots$ & ........................ & In Blind Canyon, $7,019 \mathrm{~m}$ \\
\hline F64 & 25094 & $\cdots$ & ............................. & $\begin{array}{l}\text { Between Weir Canyon and Blind } \\
\text { Canyon, } 7,475 \mathrm{~m}(24,525 \mathrm{ft}) \\
\text { south and } 9,995 \mathrm{~m}(32,800 \mathrm{ft}) \\
\text { west of the northeast corner of } \\
\text { the }\end{array}$ & & & & & $\begin{array}{l}(28,100 \mathrm{ft}) \text { west of the north- } \\
\text { east corner of the Black Star } \\
\text { Canyon quadrangle, elevation } \\
365 \mathrm{~m}(1,200 \mathrm{ft}) \text {. }\end{array}$ \\
\hline & & & & $\begin{array}{l}\text { the } \\
\text { rangle, elevation } 340 \mathrm{~m}(1,120\end{array}$ & F77 & 25107 & $\cdots$ & .................. do & $\begin{array}{l}\text { Near divide between Blind Can- } \\
\text { yon and Fremont Canyon, } 7,770 \\
\mathrm{~m}(25,500 \mathrm{ft}) \text { south and } 7,390\end{array}$ \\
\hline F65 & 25095 & $\cdots$ & ................. do & $\begin{array}{r}\text { Between Fremont Canyon and } \\
\text { Black Star Canyon, } 9,785 \mathrm{~m} \\
(32,100 \mathrm{ft}) \text { south and } 5,975 \mathrm{~m} \\
19,600 \mathrm{ft}) \text { west of the north- } \\
\text { east corner of the Black Star }\end{array}$ & & & & & $\begin{array}{l}\mathrm{m}(24,250 \mathrm{ft}) \text { west of the } \\
\text { northeast corner of the Black } \\
\text { Star Canyon quadrangle, eleva- } \\
\text { tion } 395 \mathrm{~m}(1,300 \mathrm{ft}) \text {. }\end{array}$ \\
\hline & & & & $\begin{array}{l}\text { Canyon quadrangle, elevation } \\
465 \mathrm{~m}(1,520 \mathrm{ft}) \text {. }\end{array}$ & F78 & 25108 & $\cdots$ & J. G. Vedder & $\begin{array}{l}\text { Between Fremont Canyon and } \\
\text { Black Star Canyon, } 9.980 \mathrm{~m}\end{array}$ \\
\hline
\end{tabular}




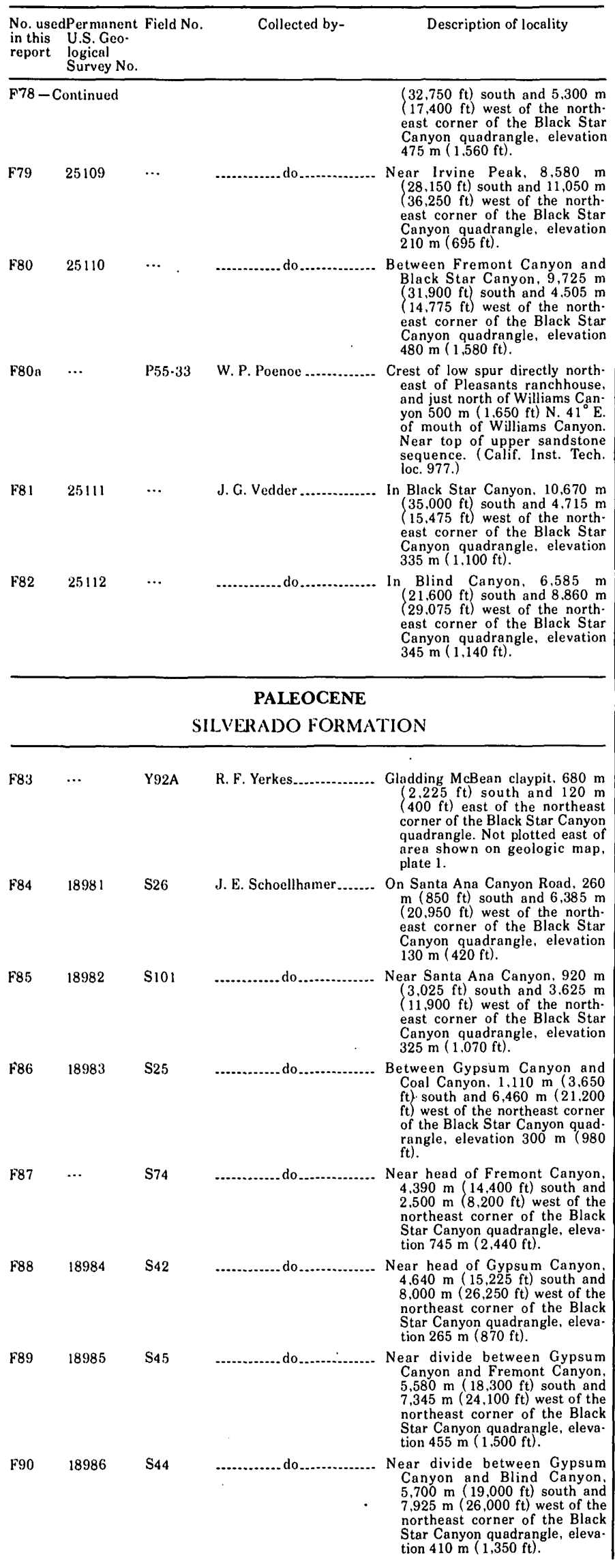

\begin{tabular}{|c|c|c|c|c|}
\hline $\begin{array}{l}\text { No. used } \\
\text { in this } \\
\text { report }\end{array}$ & $\begin{array}{l}\text { dPermanent } \\
\text { U.S. Geo- } \\
\text { logical } \\
\text { Survey No. }\end{array}$ & Field No. & Collected by- & Description of locality \\
\hline F91 & 18987 & $\cdots$ & J. G. Vedder ................... & $\begin{array}{l}\text { Near divide between Gypsum } \\
\text { Canyon and Blind Canyon, } \\
5,915 \mathrm{~m}(19,400 \mathrm{ft}) \text { south and } \\
7,795 \mathrm{~m}(25,575 \mathrm{ft}) \text { west of the } \\
\text { northeast corner of the Black } \\
\text { Star Canyon quadrangle, eleva- } \\
\text { tion } 420 \mathrm{~m}(1,380 \mathrm{ft}) \text {. }\end{array}$ \\
\hline F92 & 18988 & $\cdots$ & $\begin{array}{l}\text { D. M. Kinney, } \\
\text { J. E. Schoellhamer, } \\
\text { and W. P. Woodring }\end{array}$ & $\begin{array}{l}\text { On divide between Gypsum Can- } \\
\text { yon and Fremont Canyon, } 5,685 \\
\mathrm{~m}(18,650 \mathrm{ft}) \text { south and } 7,795 \\
\mathrm{~m}(23,975 \mathrm{ft}) \text { west of the } \\
\text { northeast corner of the Black } \\
\text { Star Canyon quadrangle, eleva- } \\
\text { tion } 490 \mathrm{~m}(1,600 \mathrm{ft}) \text {. }\end{array}$ \\
\hline F93 & 18989 & $\cdots$ & $\begin{array}{l}\text { A. E. Altinli and } \\
\text { J. G. Vedder }\end{array}$ & $\begin{array}{l}\text { Near divide between Gypsum } \\
\text { Canyon and Fremont Canyon, } \\
6,050 \mathrm{~m}(19,850 \mathrm{ft}) \text { south and } \\
7,215 \mathrm{~m}(23,675 \mathrm{ft} \text { ) west of the } \\
\text { northeast corner of the Black } \\
\text { Star Canyon quadrangle, eleva- } \\
\text { tion } 510 \mathrm{~m}(1,670 \mathrm{ft}) \text {. }\end{array}$ \\
\hline F94 & 18990 & $\cdots$ & J. G. Vedder ................ & $\begin{array}{l}\text { Near divide between Gypsum } \\
\text { Canyon and Fremont Canyon, } \\
6,120 \mathrm{~m}(20,075 \mathrm{ft}) \text { south and } \\
6.515 \mathrm{~m}(21,375 \mathrm{ft}) \text { west of the } \\
\text { northeast corner of the Black } \\
\text { Star Canyon quadrangle, eleva- } \\
\text { tion } 495 \mathrm{~m}(1,625 \mathrm{ft}) \text {. }\end{array}$ \\
\hline F95 & $\cdots$ & $\begin{array}{l}\text { Pomona } \\
\text { College } \\
\text { locality } \\
160\end{array}$ & 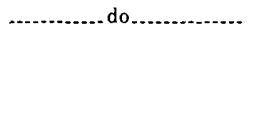 & $\begin{array}{l}\text { Near mouth of Weir Canyon, } \\
7,110 \mathrm{~m}(23,325 \mathrm{ft}) \text { south and } \\
135 \mathrm{~m}(450 \mathrm{ft} \text { west of the } \\
\text { northeast corner of the Orange } \\
\text { quadrangle, elevation } 290 \mathrm{~m} \\
(950 \mathrm{ft}) \text {. }\end{array}$ \\
\hline F96 & $\cdots$ & V16 & ..................................... & $\begin{array}{l}\text { Between Weir Canyon and Irvine } \\
\text { Park, } 7,940 \mathrm{~m}(26,050 \mathrm{ft}) \text { south } \\
\text { and } 10,980 \mathrm{~m}(36,025 \mathrm{ft}) \text { west } \\
\text { of the northeast corner of the } \\
\text { Black Star Canyon quadrangle. } \\
\text { elevation } 300 \mathrm{~m}(980 \mathrm{ft}) \text {. }\end{array}$ \\
\hline F97 & 18991 & $\cdots$ & .................................. & $\begin{array}{l}\text { Between Fremont Canyon and Irv- } \\
\text { ine Lake. } 10,270 \mathrm{~m}(33,700 \mathrm{ft}) \\
\text { south and } 7,835 \mathrm{~m}(25,700 \mathrm{ft}) \\
\text { west of the northeast corner of } \\
\text { the Black Star Canyon quad- }-{ }^{2} \text {. } \\
\text { rangle, elevation } 310 \mathrm{~m}(1,025 \\
\mathrm{ft}) \text {. }\end{array}$ \\
\hline F98 & $\cdots$ & $\cdots$ & A. E. Altinli ................. & $\begin{array}{l}\text { Between Fremont Canyon and Irv- } \\
\text { ine Lake, } 10,235 \mathrm{~m}(33,575 \mathrm{ft}) \\
\text { south and } 6.555 \mathrm{~m}(21,500 \mathrm{ft}) \\
\text { west of the northeast corner of } \\
\text { the Black Star Canyon quad- }-{ }^{2} \text {. } \\
\text { rangle, elevation } 355 \mathrm{~m}(1,160 \\
\mathrm{ft}) \text {. }\end{array}$ \\
\hline F99 & 18992 & $\cdots$ & $\begin{array}{l}\text { A. E. Altinli and } \\
\text { J. G. Vedder }\end{array}$ & $\begin{array}{l}\text { Between Fremont Canyon and Irv. } \\
\text { ine Lake, } 10,455 \mathrm{~m}(34,300 \mathrm{ft}) \\
\text { south and } 6,735 \mathrm{~m}(22,100 \mathrm{ft}) \\
\text { west of the northeast corner of } \\
\text { the Black Star Canyon quad. } \\
\text { rangle, elevation } 355 \mathrm{~m}(1,040 \\
\mathrm{ft} \text { ). }\end{array}$ \\
\hline \multicolumn{5}{|c|}{ EOCENE } \\
\hline \multicolumn{5}{|c|}{ SANTIAGO FORMATION } \\
\hline
\end{tabular}

\begin{tabular}{lllll}
\hline F99a & $\ldots$ & S97 & J. E. Schoellhamer & On Santa Ana Canyon Road, $10 \mathrm{~m}$
\end{tabular} $\left\{\begin{array}{l}25 \mathrm{ft}) \text { south and } 3.300 \mathrm{~m} \\ 10.825 \mathrm{ft}) \text { west of the north. }\end{array}\right.$ $(10.825 \mathrm{ft})$ west of the north.
east corner of the Black Star Canyon quadrangle, elevation

F99b … S394 J. E. Schoellhamer...... Northeast of Elsinore fault, $625 \mathrm{~m}$ $(2,050 \mathrm{ft})$ south and $640 \mathrm{~m}$ $(2,100 \mathrm{ft})$ west of the northeast guadrangle, elevation $245 \mathrm{~m}$

F100 $18993 \quad$ S34

Near head of Gypsum Canyon, $4.405 \mathrm{~m}(14,450 \mathrm{ft})$ south and $7,880 \mathrm{~m}(25,850 \mathrm{ft})$ west of the Star Canyon quadrangle, elevation $270 \mathrm{~m}(880 \mathrm{ft})$.

F101 $18994 \quad \ldots \quad$ J.G. Vedder .............. Near divide between Gypsum Canyon and Fremont Canyon,
$5,965 \mathrm{~m}(19,575 \mathrm{ft})$ south and $7,360 \mathrm{~m}(24,150 \mathrm{ft})$ west of the northeast corner of the Black Star Canyon quadrangle, eleva. tion $520 \mathrm{~m}(1,700 \mathrm{ft})$.

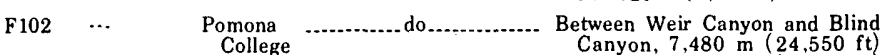
Canyon, $7,480 \mathrm{~m}(24,550 \mathrm{ft})$ south and $10.500 \mathrm{~m}(34,450 \mathrm{ft})$
west of the northeast corner of he Black Star Canyon quad. rang. 


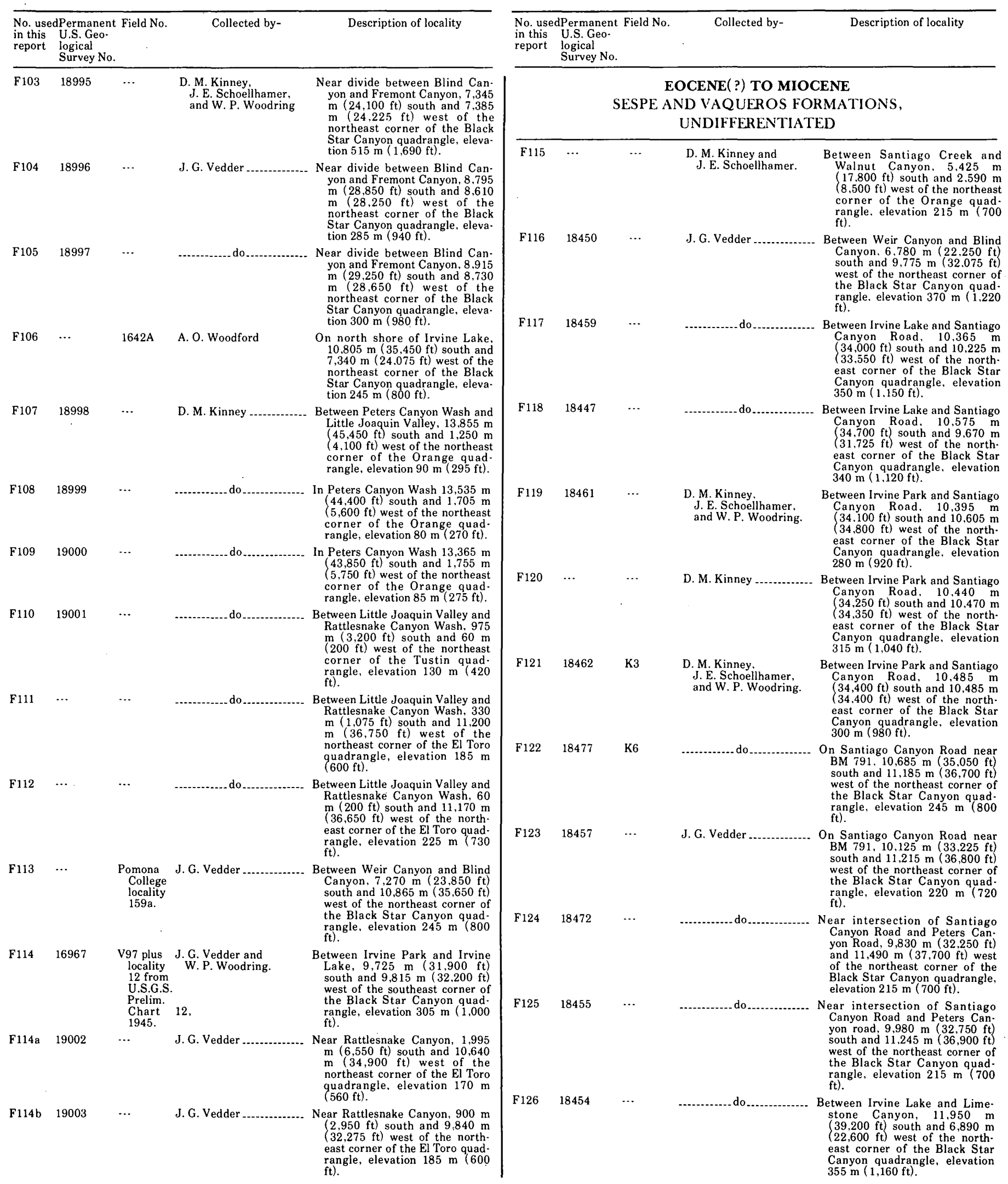




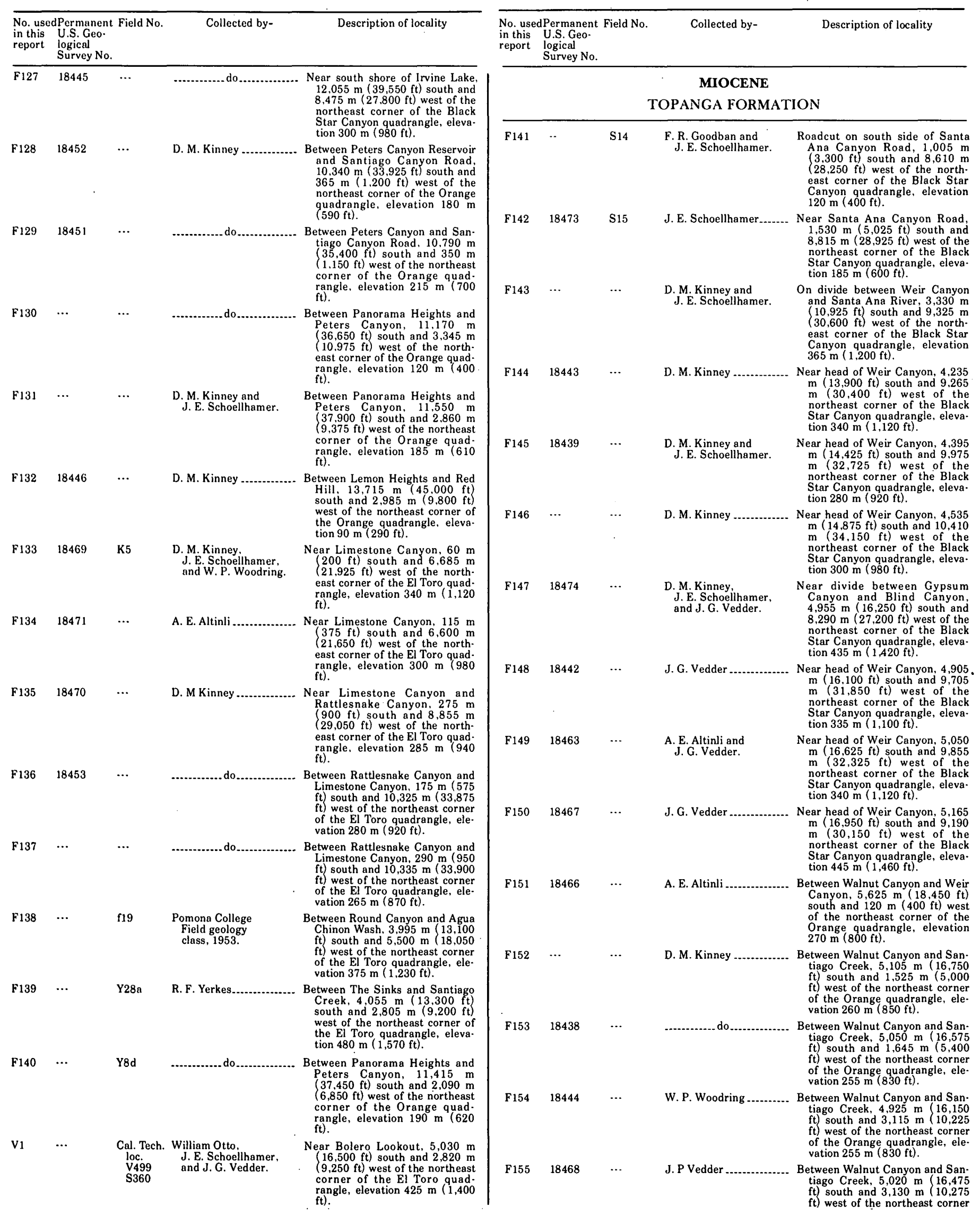




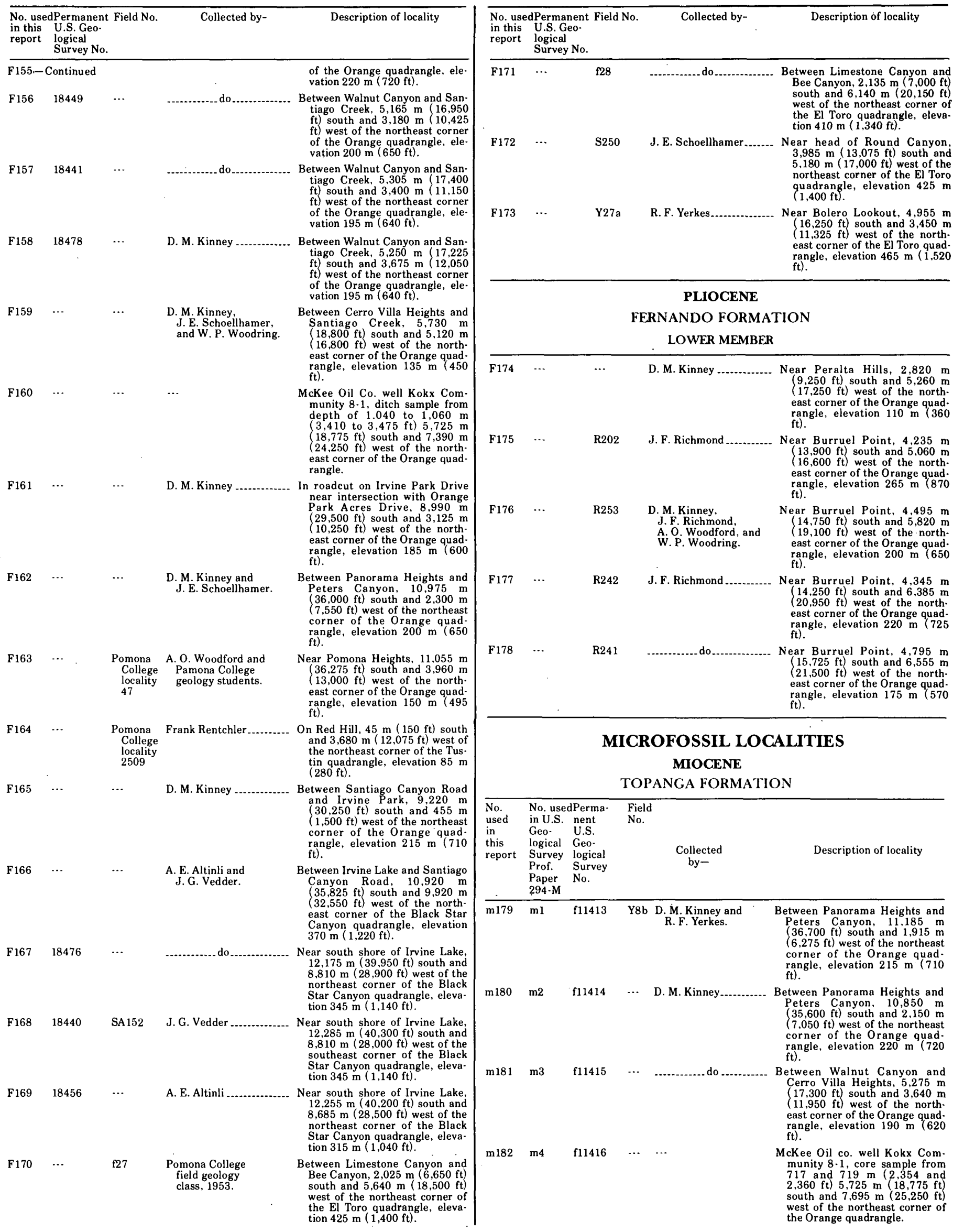




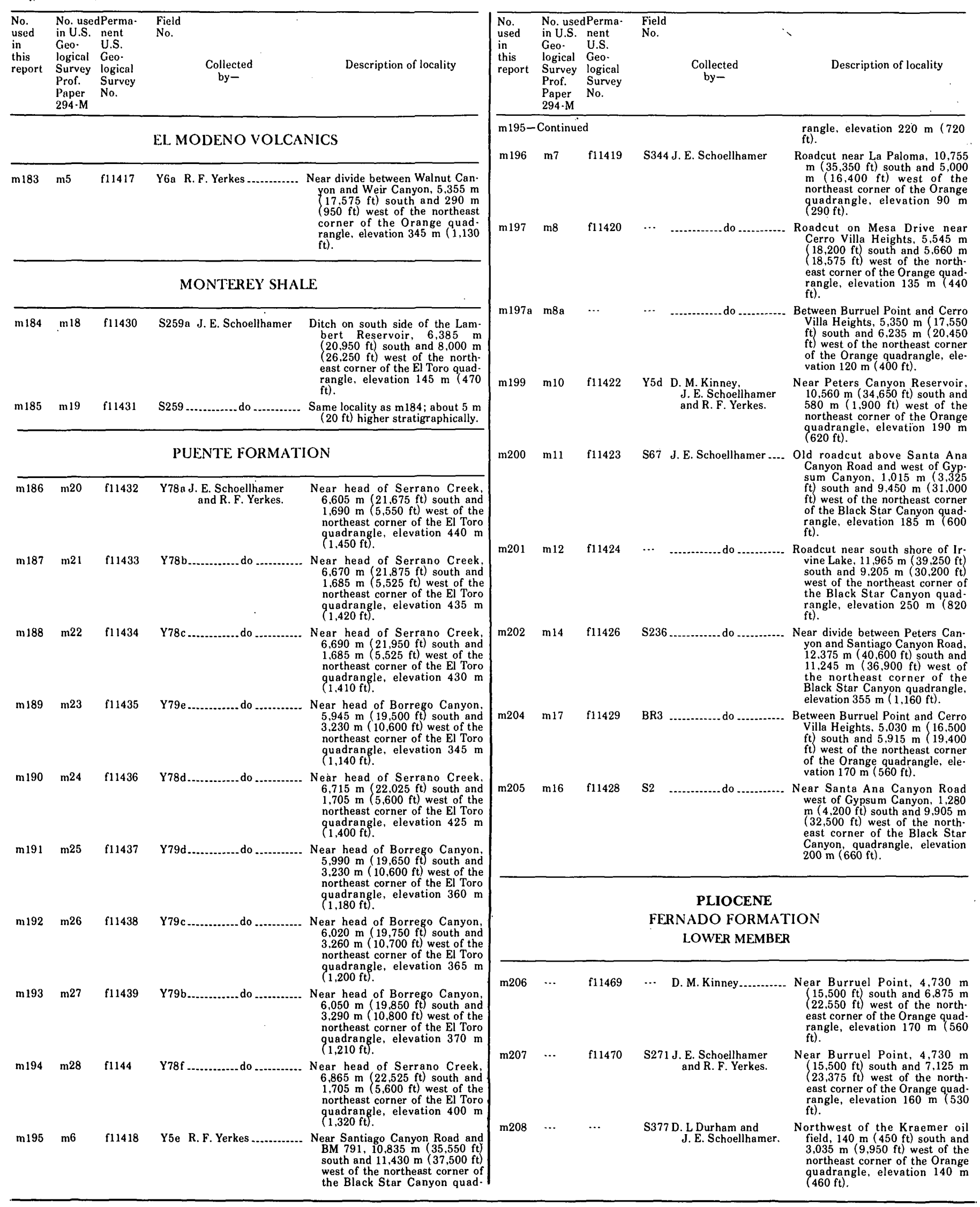




\section{INDEX}

[Note: Lists of names and localities in section "Supplemental Information" have not been indexed. Italic page numbers indicate major references.]

Agua Chinon Wash, 41, 42, 44, 47, 52, 58

Alisitos Formation, 11

Aliso Creek, 21, 22, 41, 53

Alluvial deposits, 60

Alteration, 10

Anaheim nose, $39,66,67$

Baker Canyon, 11, 13,14, 18, 19, 22, 23, 24

Baker Canyon Conglomerate, 18

Baker Canyon Conglomerate Member, 11, 12, 13, 15, 63

Bedford Canyon, 3

Bedford Canyon Formation, 3, 6, 8, 9, 10, 11, 12, 21, $22,23,30,43,62,63,66$

Bee Canyon, 21, 41, 42, 43, 47, 52, 58, 64, 65, 66 Black Star Canyon, 6, 11, 12, 13, 14, 15, 17, 18, 20, 22, $26,27,28,65$

Black Star Creek, 11

Blind Canyon, 19, 61

Bolero Lookout, 34, 36

Borrego Canyon, 52

Brea Canyon, 58

Burruel Ridge, $32,34,36,38,40,42,44,47,48,49,50$, $51,53,54,56,60,65,66$

Cahuenga Pass, 42

Capistrano Formation, 41, 47, 52, 56, 57, 64

Carbon Canyon, 58

Chapman sand, 49,50

Chico Formation, 11

Chino trough, 63

Claymont Clay Bed, 21, 23, 26, 27

Coal Canyon, 15, 17, 21, 22, 26, 30, 31

Corona trough, 63

Coyote Hills, 39

Cretaceous System, 6, 11, 67

Cristianitos fault, 41

Domengine Formation, 31

Domenguez oil field, 41

East Coyote oil field, 48

El Modeno, 42

El Modeno Volcanics, 37, 39, 46, 57, 60, 64

El Modeno fault, 64,65

Elsinore fault, 11, 21, 63, 65

Eocene Series, 28, 31, 67

Epidotization, 10

Espada Formation, 11

Eugenia Formation, 11

Faults, 63

Fernando Formation, 51, 53, 59, 65, 66

Fold8, 65

Fossils:

Amphimorphina californica, 31

Amphistegina californica, 31

Anadara (Larkinia) santana, 36

Atira ornatissimus, 21

Brachysphingus lyratus, 28

Buchia piochii, 11

Calva bowersiana, 21

Cassidulina, 56

Chione temblorensis, 39

Cibicides mcmastersi, 31

pseudowellerstorffi, 31

Coralliochama, 19

Crassatella lomana, 17

tuscana, 17

Crassostrea titan subtitan, 39

Cucullaea, 13

mathewsonii, 28

gravida zone, 15

Discoaster sublodoensis, 31

Ellipsoglandulina fragilis, 53

Epistominella subperuviana, 56

Eriphyla lepidus, 17

Etea angulata, 17

Gaudryina (Pseudogaudryina) coalingensis alata, 31

Glycymeris pacificus zone, 15 veatchii zone, $16,19,2$
Fossils-Continued

Gyroidina simiensis, 31

Haplophragmoides nonionelloides, 31

Kewia fairbanksi santanensis, 36

Legumen ooides, 2

Lembulus striatula, 21

Leptopecten andersoni, 39

$$
\text { discus, } 46
$$

Massilina decorata, 31

Meekia, 21

Megapetalus lovenioides, 53

Metaplacenticeras pacificum, 21

Opis, 19

Parallelodon vancouverensis, 17

Paratylopus primaevus, 36

Perissolax tricarnatus, 26

Pterotrigonia, 13

Rapana vaquerosensis imperialis, 34, 36

Spondylus, 13

Subprionocyclus, 15

Terebra santana, 36

Thyasira gouldii, 56

Trajanella, 19

Trigonarca, 13

Trigonarca californica zone, 15

Turritella chicoensis, 16, 19

chicoensis chicoensis, 17

chicoensis perrini, 16, 17

inezana santana, 32,34

ocoyana, 37

ocoyana topangensis, 39

pachecoensis, $26,27,28$

temblorensis, 39

Uvigerina peregrina, 56

Vertipecten nevadanus, 39

Fremont Canyon, 16, 17, 18, 19, 21, 22, 26, 28, 61, 63,

Fresno Canyon, 15, 27, 32,

Gypsum Canyon, 19, 21, 22, 27, 30, 31, 34, 37, 38

Hagador Canyon, 11

Hall Canyon, 14, 61

Harding Canyon, 11

Holocene Series, 60

Holz Ranch, 15

Holz Shale Member, 12, 13, 14, 15, 17, 21, 58, 63, 65

Inglewood oil field, 41

Introduction, 1

Irvine Lake, $15,17,18,20,26,28,38,42,65$

Irvine Park, 14, 17, 19, 20, 21, 22, 26, 28, 39, 65

Jurassic System, 3, 6, 67

Kraemer oil field, $40,50,51,52,53,54,65,66$ Kraemer zone, 48

La Habra Conglomerate, 58

La Habra Formation, 57, 58, 66

La Jolla Group, 31

La Vida Member, 40, 42, 47, 53, 57, 60, 62, 64, 65

La Vida Member, 57

Ladd Canyon, 3, 8, 12, 14, 15, 61

Ladd Formation, 11, 12, 58, 63, 65

Lambert Reservoir, 41, 58, 64

Leffingwell oil field, 36

Limestone Canyon, 32, 34, 43, 46, 48, 61, 64

Little Joaquin Valley, 11, 14, 43, 64, 65

Llajas Formation, 31

Loma Ridge, 34, 37, 42, 43, 46, 47, 48, 60, 61, 62, 64, 65 Long Beach oil field, 56

Mabey Canyon, 11

Martinez Formation, 2

Metamorphism, 10

Miocene Series, 31, 37, 42, 52, 67

Monterey Shale, $41,42,47,52,57,58$

Niguel Formation, 41, 53, 57

Oak Flat, 3, 14, 17

Oligocene Series, 67
Olive oil field, 40,51, 64, 65, 66

Oso Creek, 41, 42, 52

Oso Member, 47, 52, 64

Paleocene Series, 21, 67

Palos Verdes Hills, 41, 56

Panorama Heights, 40

Peninsular Ranges, 67

Peralta Hills, 51, 65

Peters Canyon, 32, 33, 39, 46, 64, 65

Peters Canyon Reservoir, 42

Pleasants Sandstone Member, 19, 21, 22

Pleistocene Series, 58, 60

Pliocene Series, 52, 53

Puente Formation, 36, 37, 39, 40, 41, 42, 46, 47, 48, 57, $59,60,61,62,63,64,65,66$

Puente Hills, 37, 41, 42, 58, 62, 63, 67

Quaternary System, 58

Rattlesnake Canyon, 21, 34, 43, 64 Red Hill, 38

Regional interpretations, 67

Repetto Formation, 56

Repetto Hills, 56

Richfield oil field, 46, 48, 49, 50, 51, 52, 66

Round Canyon, 42, 43, 47, 58, 61

San Joaquin Hills, 15, 37, 39, 41, 56, 67

San Joaquin Hills area, 63

San Onofre Breccia, 41, 47

Santa Ana Canyon, 13, 14, 17, 3

Santa Ana Mountains, 58, 62, 63, 64

Santa Ana River, $14,15,17,23,28,42,46,47,50,52$ $54,56,58,61,62,65,66$

Santa Monica Mountains, 41, 42

Santa Ynez Mountains, 11

Santiago Coal mine, 26

Santiago Creek, 17, 18, 20, 22, 25, 28, 32, 34, 37, 47 , $61,62,64,65$

Santiago Dam, 18

Santiago Formation, 21, 28, 31, 64, 65

Santiago Peak, 6

Santiago Peak Volcanics, 3, 6, 12, 13, 14, 62, 63, 66

Schulz Ranch Sandstone Member, 17, 19, 21

Serrano Clay Bed, 21, 22, 26, 27

Serrano Creek, 41, 53

Sespe Formation, 28, 31, 37, 41, 43, 46, 57, 58, 60, 64,

Sierra Peak, 7, 9, 10, 12, 13

Silverado Canyon, 3, 7, 8, 11, 13, 15, 18, 19, 31, 61

Silverado Formation, 19, 21, 28, 64, 65

Soquel Member, 42, 46, 52, 63, 64

Southern California batholith, 3, 6, 2

Star Quarry, 34, 35

Structure, 62

Summary, 67

Sycamore Canyon Member, 42, 49, 50,53

Temescal Wash Quartz Latite Porphyry, 9

Terrace deposits, 60

Tertiary System, 21,67

The Sinks, 32

Tierra colorado, 23

Tomato Spring, 64

Topanga Canyon, 37

Topanga Formation, 36, 37, 41, 46, 57, 60

Tourmalinization, 10

Trabuco Formation, 11

Vaqueros Formation, 28, 31, 37, 41, 43, 46, 57, 58, 60, 64,66

Walnut Canyon, 47, 48, 59, 51, 52

Wardlow Canyon, 10

Weir Canyon, 32, 34, 37, 38, 40, 43, 46

Whittier fault, 15, 27, 28, 29, 30, 32, 63, 65

Williams Canyon, 8, 11, 14, 15, 17, 19

Williams Formation, $17,21,64,65,66$

Wilmington oil field, 56

Yorba Member, 42, 46, 48, 49, 53, 57 


\section{Geology of the Eastern Los Angeles Basin, Southern California}

GEOLOG ICA L S URVEY PROFE S I ONAL PAPAR 420

This volume was published

as separate chapters $A-D$

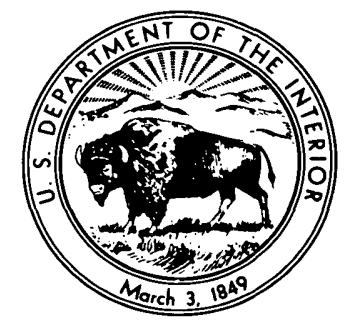




\section{UNITED STATES DEPARTMENT OF THE INTERIOR}

\section{JAMES G. WATT, Secretary}

\section{GEOLOGICAL SURVEY}

Dallas L. Peck, Director 


\section{CONTENTS}

[Letters designate the separately published chapters]

(A) Geology of the Los Angeles basin California - an introduction, by R. F. Yerkes, T. H. McCulloh, J. E. Schoellhamer, and J. G. Vedder.

(B) Geology and oil resources of the eastern Puente Hills area, southern California, by D. L. Durham and R. F. Yerkes.

(C) Geology and oil resources of the western Puente Hills area, southern California, by R. F. Yerkes.

(D) Geology of the northern Santa Ana Mountains, California, by J. E. Schoellhamer, J. G. Vedder, R. F. Yerkes, and D. M. Kinney. 